\title{
Contest and Consent: A Legal History of Marital Rape
}

\author{
Jill Elaine Hasday $\dagger$
}

Introduction.

I. The Marital Rape Exemption as it was Articulated, Understood, and Defended in the Nineteenth Century

A. Women's Legal Status in the Nineteenth Century

1. The Consensual Account of Nineteenth-Century

Women's History

2. The Law of Marriage in the Nineteenth Century

B. The Marital Rape Exemption in Nineteenth-Century

Criminal Law

C. The Marital Rape Exemption's Effect on the Lived

Experience of Marriage in the Nineteenth Century

II. The First Organized Feminist Campaign Agamst

a Husband's Conjugal Rights

A. A Wife's Right to Her Person as the Predicate for Women's Equality

B. Structural Consent and Marriage as Legalized Prostitution

C. The First Woman's Rights Campaign Against Marital Rape as a Distmctly Nineteenth-Century Movement

Copyright $\odot 2000$ California Law Review, Inc. California Law Review, Incorporated (CLR) is a California nonprofit corporation. CLR and the authors are solely responsible for the content of their publications.

$\dagger \quad$ Assistant Professor, University of Chicago Law School. B.A. 1994, J.D. 1997, Yale University. I would like to thank Reva Siegel, Emily Buss, Naomi Cahn, Mary Anne Case, Nancy Cott, Ariela Dubler, Allan Erbsen, William Eskridge, Dan Fischel, Elizabeth Garrett, Jack Goldsmith, Sally Gordon, Robert Hasday, R.H. Helmholz, Neal Katyal, Saul Levmore, Andrei Marmor, Linda McClain, Martha Nussbaum, Eric Posner, Stephen Schulhofer, Cass Sunstein, Adrian Vermeule, Robin West, and the participants in faculty workshops at the University of Chicago Law School, the Boston University School of Law, the Stanford/Yale Junior Faculty Forum, and the third annual meeting of the Working Group on Law, Culture, and the Humanities. Susan Gihring, Danielle Kemp, Cicely Weathington, Jeffrey Zeeman, and the University of Chicago Law Library provided excellent research assistance. The Arnold and Frieda Shure Research Fund contributed generous financial support. 
III. Alternate Iterations of the Nineteenth-Century

Critique of Marital Rape

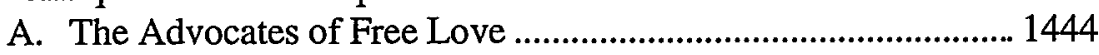

B. The Popular Prescriptive Literature..............................................1451

1. The Prescriptive Account of the

Harm of Marital Rape

2. Manly Self-Restraint and Self-Interest

IV. Circumscribed Legal Reform in the Nineteenth

Century: The Law of Divorce 1464

A. A Husband's Unwanted Sexual Demands as Legal Cruelty

B. A Wife's Refusal of Marital Intercourse as Grounds for Divorce. 1475

V. The Modern Debate over the Marital Rape Exemption .....................1482

A. The Modern Defense of the Marital Rape Exemption.................1486

B. The Modern Feminist Campaign Against the Marital Rape Exemption.................................................... 1491

C. The Lessons, and the Promise, of History .................................. 1498 


\title{
Contest and Consent: A Legal History of Marital Rape
}

\author{
Jill Elaine Hasday
}

\section{INTRODUCTION}

At common law, husbands were exempt from prosecution for raping their wives. Over the past quarter century, this law has been modified somewhat, but not entirely. A majority of states still retain some form of the common law regime: They criminalize a narrower range of offenses if committed within marriage, ${ }^{1}$ subject the marital rape they do recognize to less serious sanctions, ${ }^{2}$ and/or create special procedural hurdles for marital rape prosecutions. ${ }^{3}$ The current state of the law represents a confusing imix of victory and defeat for the exemption's contemporary feminist critics. Virtually every state legislature has revisited the marital rape exemption over the last twenty-five years, but most have chosen to preserve the exemption in some substantial manifestation. With rare exception, moreover, courts have not invalidated state laws protecting marital rape. ${ }^{4}$ Political protest and legislative action, rather than any clear judicial

1. See, e.g., Alaska Stat. $\$ 11.41 .432$ (Michie 1998); ARIz. Rev. Stat. ANN. \$§ 13-1406.01, 13-1407(D) (West 1989); ARK. CoDE ANN. §§ 5-14-103, 5-14-105, 5-14-109 (Michie 1997); CAL. Penal Code $\S \S 261,262$ (West 1988); Conn. Gen. STAT. \$§ 53a-65(2)-(3), 53a-70b(b) (1994); IDAHO CODE $\S 18-6107$ (1997); Iowa CODE $\S 709.4(1)$-(2) (1993); KAN. Stat. ANN. § 21-3517(a) (1995); Ky. Rev. Stat. ANN. \$ 510.035 (Banks-Baldwin 1990); La. Rev. Stat. ANN. §§ 14:43, 14:43.1, 14:43.3 (West 1997); MD. ANN. CoDE art. 27, § 464D (1996); Mrch. Comp. Laws $\$ 750.520 l$ (1991); Minn. STat. § 609.349 (1987); Miss. Code Ann. §97-3-99 (1994); Nev. Rev. Stat. § 200.373 (1997); N.H. Rev. Stat. ANN. §§ 632-A:2, 632-A:5 (1996); Ohio Rev. Code ANN. §§ 2907.01(L), 2907.02 (West 1997); OKLA. STAT. tit. 21, § 1111 (1983); R.I. GEN. LAWS \$§ 11-37-1(9), 11-37-2 (1994); S.C. Code ANN. § 16-3-658 (Law. Co-op. Supp. 1999); S.D. Codified LAws \$§ $22-$ 22-7.2, 22-22-7.4 (Michie 1998); TENN. Code ANN. § 39-13-507 ( Supp. 1999); VA. Code ANN. §§ 18.2-61, 18.2-67.1, 18.2-67.2, 18.2-67.2:1 (Michie 1999); WASH. REv. CODE \$\$ 9A.44.010(3), 9A.44.050, 9A.44.060, 9A.44.100 (1988); WYo. STAT. ANN. \$ 6-2-307 (Michie 1997); infra notes 408409 and accompanying text.

2. See, e.g., ARIZ. Rev. Stat. ANn. $\S 13-1406.01$ (B) (West 1989) (giving judge discretion to treat marital rape as a misdemeanor); VA. CODE ANN. §§ 18.2-61(D), 18.2-67.1(D), 18.2-67.2(D), 18.2-67.2:1(C) (Michie 1999) (permitting court, if state prosecutor and victim agree, to place marital rapist on probation pending completion of counseling or therapy; once counseling or therapy is completed, court may discharge rapist and dismiss proceedings if it "finds such action will promote maintenance of the family unit and be in the best interest of the complaining witness").

3. See, e.g., CAL. Penal Code $\$ 262$ (b) (West 1988) (one-year reporting requirement, unless victim's allegation is corroborated by independent evidence that would be admissible at trial); 720 ILL. Comp. STAT. 5/12-18(c) (West 1993) (thirty-day reporting requirement, unless court finds good cause for delay); S.C. CoDE ANN. § 16-3-658 (Law. Co-op. Supp. 1999) (thirty-day reporting requirement).

4. See infra notes $470-471$ and accompanying text. 
statement of constitutional norms, has driven the partial and uneven modification of the common law rule.

If the modern opponents and defenders of the marital rape exemption agree on any question, it is that their dispute is a new one. The contemporary debate over the exemption operates on the assumption that the law's treatment of marital rape first became controversial in the late twentieth century. Supporters of the exemption frequently assert that women never saw the need to challenge a husband's conjugal rights until approximately twenty-five years ago. The drafters of the American Law Institute's Model Penal Code, who offer the most sophisticated contemporary defense of the exemption, explain that the rule-cso long an accepted feature of the law of rape"-has only "recently come under attack." Judges similarly note that "until 1977 there was no serious challenge to the spousal exemption," or observe that "[u]ntil the late 1970 's there was no real examination of" the subject whatsoever? Prominent modern feminists, in turn, identify themselves as part of the first organized political opposition to marital rape, "a reality about which little systematic was known before 1970." debate consider historical questions at all, they generally content themselves with a brief citation to Sir Matthew Hale, who wrote the most influential treatise defending the marital rape exemption at common law. ${ }^{9}$

5. Model Penal Code and Commentaries $\$ 213.1 \mathrm{cmt}$. 8(c), at 343 (Official Draft and Revised Comments 1980).

6. People v. De Stefano, 467 N.Y.S.2d 506, 511 (Suffolk County Ct. 1983) (noting "the extensive research done by this Court").

7. Warren v. State, 336 S.E.2d 221, 223 (Ga. 1985).

8. Catharine A. MacKinnon, Toward a Feminist Theory of the State 242 (1989) [hereinafter MacKinnon, Toward]; see also Catharine A. MacKinnon, Feminism Unmodified 5 (1987) ("Since 1970, feminists have uncovered a vast amount of sexual abuse of women by men. Rape, battery, sexual harassment, sexual abuse of children, prostitution, and pornography, seen for the first time in their true scope and interconnectedness, form a distinctive pattern: the powcr of men over women in society.") (emphasis added); SusAn MOLLER OKIN, Justice, GeNDER, AND THE FAMILy 129 (1989) ("IIn the 1970s and 1980s, partly as a result of the feminist and children's rights movements that originated in the $1960 \mathrm{~s}$, wife abuse has been 'discovered' . . . Family violence is now much less sanctioned or ignored than in the past; it is becoming recognized as a serious problem that society must act on.").

9. See Warren, 336 S.E.2d at 223 ("Perhaps the most often used basis for the marital rape exemption is the view set out by Lord Hale in 1 Hale P.C. 629. It is known as Lord Hale's contractual theory."); De Stefano, 467 N.Y.S.2d at 510-11 ("Formal recognition of a spousal exemption or immunity from rape . . . is attributed to Sir Matthew Hale (1609-1676) . . . [F]rom Hale until 1977 there was no serious challenge to the spousal exemption."); MODEL PENAL CODE AND COMMENTARIES, supra note 5, at $\$ 213.1 \mathrm{cmt}$. 8(c), at 342 ("The traditional explanation for legal incapacity to rape one's own wife is that the marriage constitutes a blanket consent to sexual intimacy which the woman may revoke only by dissolving the marital relationship." (citing Hale)); Robin West, Equality Theory, Marital Rape, and the Promise of the Fourteenth Amendment, 42 FLA. L. REv. 45, 64-65 (1990) ("Marital rape exemptions are strikingly easy to trace to misogynist roots, from Hale's infamous argument that a married woman is presumed to consent to all marital sex and, therefore, cannot bc raped, to the common law's assumption that marriage results in the unification of husband and wife...."). 
This consensual account of the history of marital rape is founded on a massive historical erasure. As Parts I through IV of this Article reveal, a husband's conjugal rights became the focus of public controversy almost immediately after the first organized woman's rights movement coalesced in $1848 .{ }^{10}$ Over the course of the next half century, feminists waged a vigorous, public, and extraordinarily frank campaign against a man's right to forced sex in marriage. This nineteenth-century debate over marital rape constitutes a powerful historical record that deserves to be examined in its own right. It also provides a useful framework from which to assess and understand the course of the modern debate over the exemption.

Public discussion and legal decision making about marital rape have proceeded without knowledge of this historical struggle. To some extent, this is because existing historical scholarship has not assimilated into the popular or legal consciousness. But the work that historians of the nineteenth century have done on the feminist call for sexual self-possession in marriage also remains very mcomplete. The leading historical accounts do not analyze the feminist effort as a legal protest and a legal demand, made in an attempt to unseat a deeply rooted common law prerogative and denied. Instead, they discuss the feminist argument for a woman's control over her husband's sexual access as a chapter in the history of birth control $^{11}$ or a moral campaign to rationalize sexual desire. ${ }^{12}$ This Article also

10. The "woman's rights movement" is the term that organized feminism used to describe itself in the second half of the nineteenth century and the name that I will employ in this Article. That designation appeared as early as the announcement for the Seneca Falls Convention of 1848, which marked the movement's start. See 1 History OF WOMAN SufFrage 67 (Elizabeth Cady Stanton et al. eds., Ayer Co. 1985) (1881) ("Woman's Rights Convention.-A Convention to discuss the social, civil, and religious condition and rights of woman, will be held in the Wesleyan Chapel, at Seneca Falls, N.Y., on Wednesday and Thursday, the 19 th and 20th of July, current; commencing at 10 o'clock A.M.").

11. Linda Gordon's groundbreaking work, which focuses on the 1870s, dominates this aspect of the history of birth control. See LINDA GORDON, WOMAN's BODY, WOMAN's RIGHT: BIRTH CONTROL. IN AMERICA 95-115 (rev. ed. 1990) [hereinafter GoRDON, WoMAN's BoDY, WoMAN's RIGHT]. As she observes, "[a] woman's right to refuse is clearly the fundamental condition of birth control." Id. at 103. An important feature of Gordon's work is to explain why the feminist commitment in the 1870s to "birth control" did not also take the form of advocating the use of contraceptive devices. See id. at 97101; Linda Gordon, Why Nineteenth-Century Feminists Did Not Support "Birth Control" and Twentieth-Century Feminists Do: Feminism, Reproduction, and the Family, in RETHINKING THE FAMily: Some Feminist Questions 140, 144-47 (Barrie Thorne ed., rev. ed. 1992) [hereinafter Gordon, Why Nineteenth-Century Feminists Did Not Support "Birth Control"]; infra text accompanying notes 222-224.

Reva Siegel's legal history of the nineteenth-century struggle over abortion also discusses sexual self-possession in marriage. Siegel explains that "[m]ost frequently, [nineteenth-century feminists] attributed the incidence of abortion to marital rape," although "they also attributed abortion to the onerous work of motherhood, some even tracing it to the expropriation of women's domestic labor in marriage." Reva Siegel, Reasoning from the Body: A Historical Perspective on Abortion Regulation and Questions of Equal Protection, 44 STAN. L. Rev. 261, 306 (1992) [hereinafter Siegel, Reasoning from the Body]; see also infra text accompanying notes 222-225.

In addition, Siegel's reading of early woman's rights advocacy about household labor and wife beating describes how nineteenth-century feminists put forth an institutional critique of marriage that 
reveals nineteenth-century feminism's garrulousness about the supposedly unspeakable. Scholars have frequently assumed that marital rape was a private concern that nineteenth-century feminists feared discussing in any public or systeniatic way. ${ }^{13}$ But the historical record niakes clear that these advocates not only publicly demanded the right to sexual self-possession

attempted to give gender-speeific meaning to the liberal vision of self-ownership. In the process of this discussion of marital labor and marital violence, she observes that feminists would occasionally offer a simultaneous eritique of marital rape in the same terms. Siegel, however, does not disentangle the marital rape claim from elaims about household labor and wife beating, explore its full dimensions, or trace its course. See Reva B. Siegel, Home as Work: The First Woman's Rights Clainis Concerning Wives' Household Labor, 1850-1880, 103 YALE L.J. 1073, 1102-06 (1994) [hereinafter Siegel, Home as Work]; Reva B. Siegel, "The Rule of Love": Wife Beating as Prerogative and Privacy, 105 YALE L.J. 2117, 2148-49 (1996) [hereinafter Siegel, "The Rule of Love"].

12. See William Leach, True Love and Perfect Union: The Feminist Reform of Sex and Society 90 (2d ed. 1989) ("If women were to control their own fertility, moral education was required to raise both sexes to an equal level of purity, to rationalize or render 'natural' and harmless male sexual desire, and to prevent disease."); $i$. at 92-93 ("In effect, feminists fixed the limits of sexual expression, organized and channeled it, thereby reducing occasions for sexual intercourse."); Blanche Glassman Hersh, "A Partnership of Equals": Feminist Marriages in 19th-Century America, in THE AMERican MAN 183, 204 (Elizabeth H. Pleck \& Joseph H. Pleck eds., 1980) (arguing that nineteenthcentury woman's rights movement advocated "late marriage and 'moral [rather than legal] restraint' within marriage. These were the only means of birth control they could accept.").

Jane Larson's work on the history of rape reform also appears to operate on the premise that nineteenth-century feminists did not systematically challenge the law's treatment of marital rape. She characterizes feminist efforts between 1885 and 1900 to raise the age-of-consent in statutory rape laws as "the first American women's rape reform initiative." Jane E. Larson, "Even a Worm Will Turn at Last": Rape Reform in Late Nineteenth-Century America, 9 YALE J.L. \& HuMAN. 1, 4 (1997).

13. For instance, Karen Sánchez-Eppler observes that in the writings of feminist-abolitionists like Angelina and Sarah Grimké and Elizabeth Cady Stanton:

Concern over the slave woman's sexual victimization displaces the free woman's fear of confronting the sexual elements of her own bodily experienee, either as a positive force or as a mechanism of oppression. The prevalence of such fear is illustrated by the caution with which even the most radical feminist thinkers avoid public discussion of "woman's rights in marriage"; only in their private correspondence do the leaders of the woman's rights movement allude to sexual rights.

Karen SÁnchez-Eppler, Touching Liberty: Abolition, Feminism, and the Politics of the Body 22 (1993); see also Blanche Glassman Hersh, The Slavery of Sex: FeministABOLITIONISTS IN AMERICA 65 (1978) ("There was little argument about the grievance [sexual abuse in marriage], but timidity and prudishness made it diffieult to discuss even privately, and feminists expressed widespread anxiety that it would frighten away potential supporters who could accept less controversial but mueh-needed reforms."); Hersh, supra note 12, at 203 ("The efforts of the feminist women and men to elevate spiritual intercourse in marriage over physical union were consistent with their demand for woman's sexual autonomy. This was played down in public rhetoric, [however,] especially in the conservative postwar period when efforts at marriage reform virtually ended.").

Ellen DuBois takes a somewhat different tack. DuBois has done a tremendous amount of work uncovering the demands of the early woman's rights movement, and she briefly discusses some instances of public feminist advocacy for a woman's right to eontrol her husband's sexual access. Yet, ultimately, DuBois subsumes the sexual self-ownership claim within her argument that nineteenthcentury feminists understood suffrage to be their most radical and important goal, and were willing to bypass questions of marital status in order to secure women's right to participate in the public sphere on gender-neutral terms. See Ellen Carol DuBois, Outgrowing the Compact of the Fathers: Equal Rights, Woman Suffrage, and the United States Constitution, 1820-1878, 74 J. AM. HIST. 836, 843, 856-57 (1987); infra text accompanying notes 22-25, 135-139. 
in marriage, they pressed the issue constantly, at length, and in plain language.

Excavating the nineteenth-century contest over the law's treatment of marital rape restores a significant chapter in the history of the first woman's rights movement in the United States, offering a new perspective on the commitments and effectiveness of that movement. Historians have often characterized the first woman's rights movement as narrowly intent on securing gender-neutral rights of access to the public sphere, ${ }^{14}$ with suffrage defined as the movement's overriding and most radical goal..$^{15}$ Yet leading mineteenth-century feminists argued-in public, vociferously, and systematically - that economic and political equality, including even the vote, would prove hollow, if women did not win the right to set the terms of marital intercourse. Indeed, feminists explained a woman's lack of control over her person as the key foundation of her subordination. This claim was acutely gender-specific, grounded in the argument that women needed to control the terms of marital intercourse in order to regulate the portion of their lives they would have to devote to raising children. Convinced that women's subordination was ultimately rooted in the structure of marital relations, feminists dennanded both the right to refuse and viable socioeconomic alternatives to submission.

This agenda, admittedly radical, was neither dismissed nor ignored in the latter half of the nineteenth century, although it never fully transformed customary norms. The popular prescriptive (advice and instructional) literature on marriage contains strong evidence that the feminist critique of marital rape resonated with evolving societal understandings of desirable marital conduct. Very soon after nineteenth-century feminists began speaking about a wife's right to her own person, mainstreain prescriptive authors began to offer extended analyses of the harm that marital rape inflicted. This prescriptive literature, however, did not challenge a husband's legal right to control marital intercourse. It marshaled, instead, an array of moral, physiological, and strategic arguments designed to convince husbands to voluntarily cede discretion over sex to their wives, promising that the concession would serve the interests of husbands as well as wives. In the hands of the popular prescriptive hiterature, the feminist demand for enforceable rights to protect women froin subordination to their husbands was recast into a series of suggested strategies for narital mutuality, to be pursued in a husband's interest as he saw fit.

Ultimately, the law of marital rape changed only incrementally in the nineteenth century, and only in the context of divorce. As an episode of law reform, the course of the nineteenth-century feminist campaign against inarital rape illuminates a deep cultural resistance to altering this

14. See infra text accompanying notes 134-140.

15. See infra text accompanying notes $18-27$. 
aspect of the law, at a time when other aspects of married women's legal status were beginning to evolve. States willing to augment the property rights of married women in the middle of the nineteenth century, ${ }^{16}$ or to ratify woman suffrage in the early twentieth century, ${ }^{17}$ were emphatically unwilling to subject husbands to prosecution for marital rape. At least in this arena where sexual and reproductive relations were so directly implicated, authoritative legal sources proved staunchly opposed to the notion of incorporating into the law a vision of marriage as a potentially disharmonious, abusive, even dangerous site of human interaction, in which wives might need and deserve legal rights against their husbands.

The progress of this nineteenth-century debate on marital rape sheds new light on the modern contest over the exemption and helps explain its trajectory. As Part V discusses, one of the most striking aspects of the modern defense of the marital rape exemption-not generally remarked on as such by modern commentators but clear in the light of history-is that it assumes the aligned interests of husband and wife. The exemption's contemporary defenders argue that the rule's continued existence protects marital privacy and promotes marital harmony and reconciliation, leaving both husband and wife better off. In fact, they go farther than that. In the vision of the modern defense of the marital rape exemption, the assumption of aligned interests between husband and wife is so strong that proponents do not acknowledge that a marital rape exemption might cause wives harm. The argument assumes that a wife's interests, like her husband's, are fully and consistently served in a marital relationship shielded from the possibility of criminal prosecution for rape.

This line of reasoning has proven extremely successful, despite contemporary feminist efforts to analyze the exemption as an instrument of women's legal subordination. To be sure, the marital rape exemption has undergone more adjustment in the late twentieth century than in the nineteenth. The only change in the law's treatment of marital rape that nineteenth-century feminists lived to see consisted of marginal alterations in the terms on which divorce was available. Over the past quarter century, in contrast, a minority of states have eliminated the exemption and the rest have reduced its scope. But the marital rape exemption still survives in considerable measure in most states, at a time when the repudiation of women's legal subordination that was just beginning in the middle of the nineteenth century has been virtually completed as at least a formal matter. Twentieth-century feminists, like the nineteenth-century woman's rights movement, have had an impact on the law of marital rape, but one that falls far short of their aspirations or their level of success in other legal contexts.

16. See infra text accompanying notes 18-21.

17. See infra note 26 and accompanying text. 
In part, the dominant consensual vision of the history of marital rape helps explain why this modern argument from aligned interests has been so powerful. When one starts with the assumption that women have long accepted the marital rape exemption without protest, the proposition that the exemption continues to operate to the mutual benefit of husbands and wives is more likely to seem plausible and even mtuitively convincing. That position might be more difficult to sustain in light of a history of feminist argument and advocacy describing a husband's conjugal rights as a crucial constitutive element of women's oppression.

Yet it would be farfetched to suppose that the current legislative commitment to maintaining the marital rape exemption in substantial form, and the judicial decision not to intervene through equal protection doctrine, would suddenly dissipate if the record of struggle over marital rape were widely known. If the history of the nineteenth-century campaign against marital rape suggests anything, it is that the societal reluctance to acknowledge the possibility of antagonistic interests and hurtful behavior in marriage through the granting of legal rights to women is long-established, deeply embedded, and highly resistant to feminist challenge, particularly where questions of marital intercourse are at stake. On this view, it is hardly surprising that modern defenders of the exemption have been so inchined to assume and assert that the historical survival of a husband's conjugal privileges was uncontested; we have a tremendous cultural need to understand marital relations as consensual and harmonious, notwithstanding the contrary evidence we confront about the nature of some unions. The modern defense of the marital rape exeniption is one of the most obvious, if odd, manifestations of that phenomenon. Never do we hear more about the joys of marital love, trust, and intiniacy in a contemporary legal context than when courts, lawmakers, and commentators justify the preservation of a husband's legal right to rape his wife.

There is a highly relevant difference between the environment in which the first organized woman's rights movement campaigned against marital rape and present social and legal conditions, however, which suggests that the future course of the modern campaign against marital rape need not run parallel to that of its nineteenth-century predecessor. In the nineteenth century, the harm that a husband's right to marital rape inflicted upon wives was freely and explicitly acknowledged as a social matter. In an era still committed to a wide variety of legal structures subordinating women to men, that acknowledgment was not enough to convince mainstream writers or authoritative legal sources that the creation of legal rights protecting women against their husbands was an appropriate remedy. The modern defense of the marital rape exemption, in contrast, obscures and denies the harm that the rule inflicts upon women. This has been a crucial tactic because the injury that marital rape causes is far 
harder to defend, and the absence of legal remediation far harder to justify, in a nation now explicitly committed to women's legal equality. The historical record of struggle over marital rape helps reveal this harm, making concrete what the marital rape exemption's contemporary champions have concealed. In the process, this history provides a foundation upon which the modern feminist campaign against marital rape can build.

I

The Marital Rape Exemption as it was Articulated, Understood, AND DEFENDED IN THE NINETEENTH CENTURY

\section{A. Women's Legal Status in the Nineteenth Century}

\section{The Consensual Account of Nineteenth-Century Women's History}

The notion that a husband's conjugal rights were not contested until the late twentieth century accords with a common mode of thinking about women's legal status. This consensual account of the history of marital rape does not draw on any factual record, and it would find no comfort there. As this Article demonstrates, a husband's conjugal rights generated profound controversy in the latter half of the nineteenth century, virtually from the moment that the first feminist movement was organized. The account operates, instead, on a presumption: that longstanding aspects of women's legal status must have survived to the modern age because they embody a set of shared norms, long agreed to by women and men alike.

The premise that women's legal status is the product of consensual agreement is prominent even in many historical examinations of the first woman's rights movement. This line of scholarship acknowledges, of course, that nineteenth-century feminists campaigned to overturn laws subordmating women to men. But it depicts the feminist protest as limited in scope, and ultimately successful in convincing legislatures to reform the law wherever feminists pushed forcefully for change. These narratives of the nineteenth-century woman's rights movement stress the passage of the married women's property acts in a number of state legislatures, starting in the 1840s. At common law, married women had little, or no, right to contract, own property, or sue. ${ }^{18}$ Some of the first married women's property acts modified this common law regime by codifying court decisions that permitted married women to hold their own property in equitable trusts and by protecting a wife's real property from her

18. See Norma Basch, In the Eyes of the Law: Women, Marriage, and Property in Nineteenth-Century New YoRK 17, 51-55 (1982); Michael Grossberg, Governing the HeARTH: LAW AND THE FAMILY IN NINETEENTH-CENTURY AMERICA 25 (1985); ElizABETH Bowles Warbasse, The Changing Legal Rights of MARried Women, 1800-186I, at 7-21 (1987); Richard H. Chused, Married Women's Property Law: 1800-1850, 71 GEo. L.J. 1359, 1365-68 (1983). 
husband's debts. ${ }^{19}$ Later statutes, enacted from the 1850 s onwards, granted wives the right to keep their own earnings. ${ }^{20}$ All of this legislation, however, focused on questions of property distribution between husbands and wives that were of immediate practical concern to relatively few women: Only a small subset of wives in the nineteenth century either owned real property or worked outside the home. ${ }^{21}$ A number of historians nonetheless describe the married women's property acts as satisfying feminists' demands for the reform of marital status law..$^{22}$ In this vision, the passage of the married women's property acts left suffrage as the most important, controversial, and far-reaching claim of the woman's rights

19. See James Schouler, A Treatise on the Law of the Domestic Relations 16-21 (Boston, Little, Brown, \& Co. 1870); BASCH, supra note 18, at 156-59 (on New York statutes enacted in 1848 and 1849); WARBASSE, supra note 18, at 137-247; Richard H. Chused, Late Nineteenth Century Married Women's Property Law: Reception of the Early Married Women's Property Acts by Courts and Legislatures, 29 AM. J. LEgAL Hist. 3, 3 (1985); Chused, supra note 18, at 1398-1412; Siegel, Home as Work, supra note 11, at 1082-83.

20. See Basch, supra note 18, at 164-65; AMY Dru Stanley, From Bondage to Contract: Wage Labor, Marriage, and the Market in the Age of Slave Emancipation 175 , 199-217 (1998); Siegel, Home as Work, supra note 11, at 1083, 1142-43, 1180-87; Reva B. Siegel, The Modernization of Marital Status Law: Adjudicating Wives' Rights to Earnings, 1860-1930, 82 Geo. L.J. 2127, 2141-46 (1994).

21. See Siegel, Home as Work, supra note 11, at 1084 ("In 1860, the national census reported that only $15 \%$ of all free women were engaged in paid labor, and most were single or widowed. Historians estimate that $5 \%$ of married white women worked outside the home during the nineteenth century; the 1890 census counted only $3.3 \%$ of married women working for wages."). Free black married women participated in the labor force in significantly greater numbers. See, e.g., PAULA Giddings, When and Where I ENTER: The IMPACT of Black Women on Race and Sex in AMERICA 48 (1984) ("By 1847 a census revealed that close to half the female Black population of Philadelphia consisted of washerwomen and domestic servants. ... While the White female labor force was made up primarily of single women, Black women, both married and single, were forced to

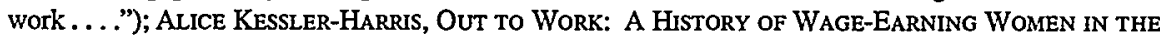
UNITED STATES 123 (1982) ("In 1880, 73.3 percent of black single women and 35.4 percent of black married women in seven southern cities reported paid jobs. Among white women only 23.8 percent of the single and 7.3 percent of the married reported paid employment.").

22. See Siegel, Home as Work, supra note 11, at 1085, 1076 (noting historians' claims that "the earnings statutes satisfied feminist economic demands," while disputing assertion with thorough account of feminist advocacy for "joint property" laws" that would entitle wives "to joint rights in marital property by reason of the [household] labor they contributcd to the family economy"); ELLEN Carol DuBois, Feminism and Suffrage: The Emergence of an Independent Women's MOVEMENT IN AMERICA, 1848-1869, at 42 (1978) (arguing that New York Married Women's Property Act of 1860 "granted New York women all the economic rights they demanded, but still refused women the right to vote"); BASCH, supra note 18, at 165 ("Every provision of the 1860 [New York] statute, it should be noted, was a specific goal of the women's movement. The New York Earnings Act, in other words, was the significant legislative realization of demands by women for women."). Zillah Eisenstein similarly writes that:

Stanton in the end focuses on the legal component of woman's oppression within marriage. She argues that because women give up their legal existence in marriage, they become nameless, purseless, and childless. The husband and wife become one person legally-the husband. The man has custody of his wife's person. He is guardian of their children, owner of her property, and has rights to her industry. Hence, the married woman has no legal status, and propertied single women are taxed without representation. If this is the problem, the solution in Stanton's mind was passage of the Married Woman's Property Act (1836-48).

Zillah R. Eisenstein, The Radical Future of Liberal Feminism 159 (1981). 
movement. Suffrage became, these historians report, "the capstone of women's emancipation."23 "Nineteenth-century feminists and anti-feminists alike perceived the demand for the vote as the most radical element in women's protest against their oppression;'24 feminists were willing to "bypass[] women's oppression within the family."25 This account explains the history of women's legal status in the nineteenth and early twentieth centuries as a story of steady liberalization and, ultimately, of consensualism. It suggests that the demands of the first feminist movement were all accommodated in turn, with the movement's agenda completed by the ratification of the Nineteenth Amendment in $1920 .^{26} \mathrm{On}$ this view, feminists never seriously challenged what remained unchanged-every aspect of the law of marriage that the married women's property acts did not reach. ${ }^{27}$

\section{DuBoIs, supra note 22 , at 40 . Aileen Kraditor similarly explains:}

Why did most feminists focus their campaign for equality so sharply on the vote between the Civil War and the passage of the Nineteenth Amendment to the Constitution in 1920? An obvious reason ... was that most of the other rights they had agitated for either had been won or were clearly on the way to being won.

Aileen S. Kraditor, Introduction to UP FROM the Pedestal: Selected WrITINGS IN the History of AMERICAN FEMINISM 3, 19 (Aileen S. Kraditor ed., 1968). Eleanor Flexner also presents suffrage as the key claim of the nineteenth-century feminist movement, the demand to which all its advocacy inexorably led. See, e.g., Eleanor Flexner, Century of Struggle: The Woman's Rights Movement In the United States 156 (rev. ed. 1975) (noting that Elizabeth Cady Stanton and Susan B. Anthony understood the vote to be the issue "of primary importance" to the woman's rights movement).

24. Ellen DuBois, The Radicalism of the Woman Suffrage Movement: Notes Toward the Reconstruction of Nineteenth-Century Feminism, 3 FEMINIST STUD. 63, 63 (1975).

25. Id.; see also STANLEY, supra note 20, at 203 ("By the postbellum era, only suffrage assumed higher priority for feminists than earnings legislation; this was a reform of marriagc law on which they could agree.").

26. See U.S. CONST. amend. XIX ("The right of citizens of the United States to vote shall not be denied or abridged by the United States or by any State on account of sex. Congress shall have power to enforce this artiele by appropriate legislation.").

Reva Siegel has argued that subsequent interpretation of the Nineteenth Amendment has itself been dominated by this same consensual vision of women's history. Advocates on both sides of the debate over woman suffrage understood the Nineteenth Amendment to have profound feminist implications for relations between the sexes, particularly in marriage. See Reva B. Siegel, Collective Memory and the Nineteenth Amendment: Reasoning About "the Woman Question" in the Discourse of Sex Discrimination, in HistoRY, MEMORY, AND THE LAW 131, 142-52 (Austin Sarat \& Thomas R. Kearns eds., 1999). Modern courts and commentators, however, have read the Nineteenth Amendment simply as a rule barring sex-based restrictions on the franchise, rather than as a source of broader constitutional norms about women's status and rights. See id. at 132-33. Siegel argues that this interpretation of the Nineteenth Amendment reflects and "in turn sustains the prevailing understanding of gender arrangements as the product of evolving social consensus rather than legal coercion and political conflict." Id. at 133.

27. Steven Buechler has a somewhat different account of the progress of the woman's rights movement, based primarily on his study of the movement in Illinois. See STEven M. Buechler, THE Transformation of The Woman Suffrage Movement: The Case of Illinots, 1850-1920, at xixiii (1986). Buechler does note that the movement began by criticizing many aspects of women's status beyond the scope of the married women's property acts, see id. at 26-27, 38-41, 88-90, but he explicitly rejects the notion that the movement ultimately turned to a narrow focus on suffrage because of the 
The history of the struggle over marital rape complicates this picture. ${ }^{28}$ It reveals that the legal demands of the nineteenth-century feminist movement were not limited to suffrage and the marginal property reforms at stake in the married women's property acts. The first organized woman's rights movement offered a much more systematic critique of women's legal status in marriage. Indeed, feminists repeatedly identified a woman's right to control the terms of marital intercourse as the predicate condition for women's equality, without which full property rights and even suffrage would be meaningless. Nevertheless, the law's treatment of marital rape hardly changed over the course of the nineteenth century, and the modest reform that did occur was limited to divorce law. The history of women's legal status in the nineteenth century did not follow just one path, of gradual progress and consistent success. Lawmakers willing to enact the married women's property acts or to ratify the Nineteenth Amendment apparently thought there was too much at stake in changing the marital rape exemption. The exemption's survival into the modern era is not evidence that the rule was never contested. The rule was maintained despite decades of feminist objection, because the exeinption's defenders were far more powerful than its critics.

\section{The Law of Marriage in the Nineteenth Century}

To appreciate what the defenders of the marital rape exemption understood to be at issue requires a brief introduction to the law of marriage in the nineteenth century. The frequent identification of the married women's property acts as the culmination of the feminist campaign for the legal reform of marriage might suggest-wrongly - that the law of marriage was somehow equalized in the middle of the nineteenth century. That was hardly the case. The marital rape exemption was explained and

strength of the opposition it encountered in seeking fundamental changes in the law of marriage, see id. at 211. Instead, Buechler argues, the middle-class women who led the woman's rights movement voluntarily dropped their challenge to marital status law as they became increasingly class-conscious and more anxious about radically disrupting the status quo. See id. at 45-47, 51-52, 95-96, 102.

28. As such, this Article fits into an emerging body of work that is returning to the primary sources to rethink the emphasis that historians of the woman's rights movement have traditionally put on suffrage specifically, and gender-neutral rights to participate in the public sphere more generally. See Elizabeth B. Clark, Religion and Rights Consciousness in the Antebellum Woman's Rights Movement, in AT THE Boundaries of LAw 188, 188-89 (Martha Albertson Fineman \& Nancy Sweet Thomadsen eds., 1991) ("Historians have overstated both the secular identity of antebellum feminism and the centrality of suffrage to that movement.... [R]ights consciousness was originally rooted in domestic concerus for many women, who saw them as a means of achieving protection for themselves and their families while pursuing the ends of social justice."); Siegel, Home as Work, supra note 11, at 1078 ("[M]ost accounts of nineteenth-century feminism have focused on the movement's quest for the vote.... But the movement's demand for joint property was no timid sister of suffrage advocacy.... [It constituted] an explosive critique of the family form-exposing the state's role in defining 'private sphere' life and demonstrating that women's economic dependence on men was a condition imposed and enforced by law."). 
defended amidst an elaborate legal regime that continued to explicitly subordinate wives to husbands.

In the nineteenth century, authoritative legal sources agreed that the rights and obligations of husbands and wives were most appropriately understood, explained, and regulated through the organizing rubric of a status/contract distinction. This distinction classified legal rules into two oppositional categories: status rules (like the marital rape exemption), which fixed marital rights and obligations in the law and made them unalterable by private agreement, and contract rules, which permitted husbands and wives, or couples contemplating marriage, to structure their own legal relationship if they preferred not to rely on the default rules set by the state. The marital relation was governed by both types of rules, mainly at alternate parts of its life cycle.

By the first half of the nineteenth century, individuals had a large measure of control over decisions about whether, when, how, and whom to marry. Nineteenth-century treatises stressed, for instance, that parental consent was not a legal prerequisite to marriage in the United States. ${ }^{29}$ Most states also held that valid marriage ceremonies did not need to take any particular form. ${ }^{30}$ Indeed, over the course of the nineteenth century, a majority of American jurisdictions recognized the legal validity of common law marriages, where the couple had not necessarily participated in a ceremony of any sort. ${ }^{31}$

Status rules were much more consequential and prominent in controlling ongoing marital relationships. A couple could choose whether to marry, but could rarely modify the legal nature of their union. The legal terms regulating married couples in the nineteenth century differed from contracts in multiple respects. First, and by definition, the status rules governing marriage provided that it was legally impossible for a husband and wife to circumvent their requirements by mutual decision. ${ }^{32}$ These

29. See 2 James Kent, Commentaries on American Law 99 (O.W. Holmes, Jr. ed., Boston, Little, Brown, \& Co. 12th ed. 1873); EdwaRd D. MANSField, The Legal Rights, Liabilities aNd Duties OF WOMEN 242-43 (Salem, John P. Jewett \& Co. 1845); SCHOULER, supra note 19, at 46.

30. See IRVING Browne, ElEMENTS of THE LAW of DOMESTIC RELATIONS AND OF EMPLoyer AND EMPLoyed 9-12 (Boston, Boston Book Co. 2d ed. 1890); KENT, supra note 29, at 100; MANSField, supra note 29, at 243-44; TAPPING REeve, THE LAW OF BARON AND FEMme 312 n.1 (Albany, William Gould 3d ed. 1862); JAMEs Schouler, A Treatise on the LaW of The Doniestic Relations 54 (Boston, Little, Brown, \& Co. 3d ed. 1882).

31. See Maryland v. Baldwin, 112 U.S. 490, $494-95$ (1884); Meister v. Moore, 96 U.S. 76, 79 (1878); 1 Joel Prentiss Bishop, Commentaries on the LaW of Marriage and Divorce 11 (Boston, Little, Brown \& Co. 4th ed. 1864); KENT, supra note 29, at 102-03; REEve, supra note 30, at 308 n.1; W.C. Rodgers, A Treatise on the Law of Domestic Relations 58-63 (Chicago, T.H. Flood \& Co. 1899); Ariela R. Dubler, Note, Governing Through Contract: Common Law Marriage in the Nineteenth Century, 107 YALE L.J. 1885, 1890-95 (1998).

32. See Maynard v. Hill, 125 U.S. 190, 211 (1888) ("[W]hen the contract to marry is executed by the marriage, a relation between the parties is created which they cannot change. Other contracts may be modified, restricted, or enlarged, or entirely released upon the consent of the parties. Not so with 
rules did not depend on securing actual consent from any particular couple; rather, they conclusively inferred consent, as a matter of law, from the couple's initial agreement to marry. ${ }^{33}$ Legal writers like Joel Bishop, author of one of the most influential family law treatises of the nineteenth century, explained that the marital relation, as the foundational unit of society, was too important to be left to the vagaries of individual will. "[T]he idea, that any government could, consistently with the general weal, permit this institution to become merely [a] matter of bargain between men and women, and not regulate it by its own power, is," he scoffed, "too absurd to require a word of refutation." 34

The marital relation in nineteenth-century law also diverged from a bilateral contract in its tremendous restrictions on the possibility of exit. A husband and wife could not simply agree to end their relationship. Marriages terminated at the death of one party or at divorce, which was only available for fault (most notably, cruelty, desertion, or adultery), and difficult to obtain even then. ${ }^{35}$ If a husband or wife became incapable-

marriage.”); Adams v. Palmer, 51 Me. 480, 483 (1863) (“[Marriage is] a new relation, the rights, duties and obligations of which rest, not upon [the couple's] agreement, but upon the general law of the State, statutory or common, which defines and prescribes those rights, duties and obligations. They are of law, not of contract."); 5 The AMERICAN AND ENGLish ENCYCLOPAdia OF LAW 746 (John Houston Merrill cd., Northport, Edward Thompson 1888) ("The relation of two married persons to each other is not a mere personal relation depending on their will, but a status, - a legal condition established by laws,-which the State has full power to create, change, and abrogate."); JOEL PRENTISS BISHOP, Commentaries on the Law of Marriage and Divorce 31 (Boston, Little, Brown \& Co. 1852) ("II]t is not in the power of the [married] parties, though of common consent, to alter any substantial, as to make the marriage for a time, or take the power over the wife from the husband, and place it in her or any other....") (citation and imternal quotation marks omitted); 1 William T. NELSON, A TrEatise ON THE LAW OF Divorce 5 (Chicago, Callaghan \& Co. 1895) ("The [marital] relation differs from a contract in the following essentials: 1 . The parties are not free to fix the terms of the agreement.").

33. See ScHOULER, supra note 19 , at 22 ("[Marriage] is a contract ..., to a certain extent, since the law always presumes two parties of competent understanding who enter into a mutual agreement.... But this agreement differs essentially from all others. This contract of the parties is simply to enter into a certain status or relation.").

34. BISHOP, supra note 31, at 10; see also Maynard, 125 U.S. at 205 ("Marriage, as creating the most important relation im life, as having more to do with the morals and civilization of a people than any other institution, has always been subject to the control of the legislature."); Adams, $51 \mathrm{Me}$. at 485 ("[Marital obligations] arise not from the consent of concurring minds-but are the creation of the law itself; a relation the most important as affecting the happiness of individuals, the first step from barbarism to incipient civilization, the purest tie of social life, and the true basis of human progress.").

35. See 1 Joel Prentiss Bishop, New Commentaries on Marriage, Divorce, and SEPARATION 16 (Chicago, T.H. Flood \& Co. 1891) ("Evils numberless, extending to the demoralization of society itself, would follow the abandonment of marriage as a permanent status, and permitting it to be the subject of experimental and temporary arrangements .... [Nevertheless,] [n] married partner should desert the other, commit adultery, beat or otherwise abuse the other ...."); KENT, supra note 29 , at 113 ("When a marriage is duly made, it becomes of perpetual obligation, and cannot be renounced at the pleasure of either or both of the parties. It continues, until dissolved by the death of one of the parties, or by divorce."); NELSON, supra note 32, at 18 ("In the divorce suit the interest of the state is paramount to the rights of the parties... . The state has an interest in marriage as a public institution; and public policy requires that the marriage be preserved in all cases where the purposes of the marriage are not defeated."); RODGERS, supra note 31 , at 3 ("[A] contract of marriage... is 
after marrying - of performing an obligation of the marital relationship (through impotence or insanity, for example), this incapacity did not free the other spouse from marital obligations and did not constitute ground for marital dissolution. ${ }^{36}$ The availability of remedies other than exit was extremely limited as well. If one spouse willfully refused to perform marital obligations, the common law did not permit the other to sue for enforcement or damages. ${ }^{37}$ Suits between husband and wife for torts like assault and false imprisonment were also prohibited. ${ }^{38}$

This structural account of status in the nineteenth-century marital relation only provides a partial picture, however. The rights and obligations of husband and wife also depended enormously, of course, on the

indissoluble in its binding force, even with the consent of the parties or either of them ...."); Schouler, supra note 19, at 22-23 ("Mutual consent ... brings them together . . . [But] [d]eath alone dissolves the tie,-unless the legislature [permits] divorce; and this it should only do when the grossly immoral conduct of one contracting party brings unmerited shame upon the other ... and inflicts a wound upon the community.").

For a more extensive discussion of the law of divorce in the nineteenth century, see infra Part IV.

36. See Ferris v. Ferris, 8 Conn. 166, 167-68 (1830) ("Corporal imbecility may arise after the marriage, which will not then vacate the marriage, because there was no fraud in the original contract.") (citation and internal quotation marks omitted); BisHoP, supra note 32, at 28 ("[Marriage] subsists in full force, even although one of the parties should be forever rendered incapable, as in the case of incurable insanity, or the like, from performing his part of the mutual contract.") (citation and internal quotation marks omitted); SCHOULER, supra note 30 , at 34 (noting that a marriage is not voidable for impotency where the "physical incapacity aris[es] from some cause subscquent to marriage").

Incapacity that existed at the time of the marriage ceremony was ground for marital dissolution. See Bascomb v. Bascomb, 25 N.H. 267, 272 (1852) (denying divorce on ground that alleged impotency "arose not only after the marriage, but as a consequence of it [specifically, injuries sustained during childbirth].... . 1t would seem to be the result not of the neglect, but of the performance of duty. It is no fault of the libellee, that she has fallen into her present condition ...."); BRowNE, supra note 30, at 5 ("Where impotence exists there can be no valid marriagc. ... The impotency must have existed at the time of the marriage."); Amos Dean, Principles of Medical JuRisprudence: Designed for the Professions of Law and Medicine 3-4 (New York, Banks \& Bros. 1866) ("[By statute, New York] provides that a marriage contract may be declared void for physical incompetency in either of the parties, which existed at the time of the marriage."); REEve, supra note 30, at 322 n. 1 ("Impotence, in order to constitute a ground of divorce, must exist at the time of the marriage, and must be incurable."); RODGERS, supra note 31 , at 12 ("The law never sanctions the annulment of a marriage on account of the disability of physical incapacity, unless the same existed at the time of the marriage.").

37. See BISHOP, supra note 32 , at 32 ("No suit at law or in cquity, sounding in contract, and going to the status itself, can be maintained between husband and wife .... And we may well conclude that where there is no remedy known to the law ... there is no right."); NELSON, supra note 32, at 5 ("The [marital] relation differs from a contract in [that] ... [n]o damages can be recovered for a violation of marital duty."); SCHOULER, supra note 19, at 56-57 ("[T]he peace of society forbids that [husband and wife] should sue one another for damages for breach of the marital obligations. Here again is marriage sui generis, and not like other contracts.").

38. See Tapping Reeve, The LaW of Húsband and Wife 93 n.l (Albany, William Gould, Jr, \& Co. 4th ed. 1888) ("1t is now settled in New York that a married woman cannot recover damagcs in a civil action against her husband for assault, notwithstanding the [1860 New York statute] allowing her to ... ‘[sue] for damages ... , the same as if she were sole."'); SCHOuLER, supra note 30, at 77-78 ("This disability of the spouses to sue one another ... . is founded on the principle that husband and wife are one.... [T] he wife has no cause of action in damages against her husband for a pure tort committcd upon her person during the marriage relation, such as assault or false imprisonment."). 
substance of these status rules. In the nineteenth century, many of these rules operated along common law principles of coverture, which explicitly subordinated wives to husbands. William Blackstone, whose treatise on the laws of England was extremely influential throughout the United States, offered the classic definition. "By marriage," he wrote,

the husband and wife are one person in law: that is, the very being or legal existence of the woman is suspended during the marriage, or at least is incorporated and consolidated into that of the husband: under whose wing, protection, and cover, she performs every thing.... Upon this principle, of an union of person in husband and wife, depend almost all the legal rights, duties, and disabilities, that either of them acquire by the marriage. ${ }^{39}$

Coverture united husband and wife by subsuming a married woman's civil identity and according husbands wide-ranging control over their wives. Legal scholars explaimed the principle in the language of hierarchical authority and obedience. As James Schouler's family law treatise elaborated, "the laws of nature and divine revelation" jointly designated the husband as "the head of the family." "It [was] for the wife to love, honor, and obey; it [was] for the husband to love, cherish, and protect." ${ }^{\text {,41 }}$

The implications of this understanding of the legal relationship between husband and wife can be found throughout nineteenth-century jurisprudence. Most notably for present purposes, a husband enjoyed substantial rights to his wife's person. ${ }^{42}$ The common law gave husbands the authority to chastise, or correct, their wives, as long as the corporal punishment did not cause permanent injury. ${ }^{43}$ Courts and commentators had

39. 1 William Biackstone, Commentaries *430.

40. SCHOULER, supra note 19 , at 53.

41. Id. (emphasis added); see also Bradwell v. Illinois, 83 U.S. (16 Wall.) 130, 141 (1873) (Bradley, J., concurring in the judgment) ("Man is, or should be, woman's protector and defender. The natural and proper timidity and delicacy which belongs to the female sex evidently unfits it for many of the occupations of civil life."); 1 Joel Prentiss Bishop, Commentaries on the LAW OF MARRIED WOMEN 27 (Philadelphia, Kay \& Brother 1871) (noting that coverture principles reflect "the law of nature, which gave strength to the man and feebleness and dependence to the woman").

42. See SCHOULER, supra note 19, at 53 ("As to the more strictly personal consequences of the marriage union, [the husband's] rights and duties have suffered no violent change at our modern law."); see also id. at 16-17 (describing a shared consensus "[t]hat as to rights of the person, or what are sometimes contrasted with civil as moral rights, no essential changes are wanted; the property rights of married women coming alone within the scope of a sweeping reform").

43. See 9 The AMerican AND ENGlish Encyclop fedia of LAw, supra note 32, at 815 ("[T]he old writers say that a husband may chastise his wife with a rod no thicker than this thumb...."); BLACKSTONE, supra note 39 , at $* 432$ ("The husband also (by the old law) might give his wife moderate correction. For, as he is to answer for her misbehaviour, the law thought it reasonable to intrust him with this power... in the same moderation that a man is allowed to correct his servants or children . ..."); BROWNE, supra note 30, at 14 ("The common-law idea of marriage is that the husband and wife become one person, and that person is principally husband .... He has the custody and control of her person. He may moderately chastise her."); 1 EMLIN MCClaiN, A TREatise on the Criminal LAw 207 (Chicago, Callaghan \& Co. 1897) ("It seems generally to be supposed that by the earlier common law the husband might lawfully inflict physical chastisement on his wife in exercising 
formally renounced this right by the latter half of the nineteenth century.4 But legal authorities continued, nonetheless, to treat wife beating more favorably than other instances of assault and battery and remained extremely reluctant to enforce criminal or civil penalties for marital violence. ${ }^{45} \mathrm{~A}$ husband could also, with only modest limitations, legally restrict his wife's movements in the nineteenth century-could conclusively determine where the couple would live,${ }^{46}$ could physically restrain his wife

over her a reasonable control, ... unless some permanent injury should be inflicted, or there should be an excess of violence...."); TAPPING ReEve, The LAW of BARON AND FEMme 65 (New Haven, Oliver Steele 1816) ("[At common law,] the husband seems to have had the same right over the person of his wife, that he had over the person of his apprentice; to chastise her moderately or confine her; a right still claimed and enforced in [England], among the lower ranks of society."); Siegel, "The Rule of Love," supra note 11, at 2121-29.

44. See Fulgham v. State, 46 Ala. 143, 146-47 (1871) ("[T] he privilege, ancient though it be, to beat [the wife] with a stick, to pull her hair, choke her, spit in her face or kick her about the floor, or to inflict upon her like indignities, is not now acknowledged by our law."); 9 THE AMERICAN AND ENGLISH ENCYCLOPEDIA OF LAW, supra note 32, at 815 ("Though the old writers say that a husband may chastise his wife with a rod no thicker than his thumb, modern law recognizes no such right, and a husband is not justified in beating his wife, even though she be drunk, or insolent."); 1 JOEL PRENTISS Bishop, Commentaries on the Criminal Law 535 (Boston, Little, Brown, \& Co. 7th ed. 1882) ("[A] former supposed right of chastisement is entirely abandoned ...."); BrownE, supra note 30, at 17 ("At ancient common law the husband had the right moderately to chastise his wife .... But under modern common law, the husband has no right to strike his wife even if she is drunk or insolent."); MCClAiN, supra note 43, at 207 ("But this authority on the part of the husband [to 'lawfully inflict physical chastisement on his wife'] has been expressly repudiated in all the recent cases on the subject ...."); REEVE, supra note 30, at 142 n.1 ("A husband has no right to inflict corporal punishment on his wife...."); SCHouler, supra note 19, at 59 ("[S]ince the time of Charles II. the wife has been regarded more as the companion of her husband; and this right of chastisement may be regarded as exceedingly questionable at the present day. The rule of love has superseded the rule of force."); Siegel, "The Rule of Love," supra note 11, at 2129 ("By the 1870s, there was no judge or treatise writer in the United States who recognized a husband's prerogative to chastise his wife.").

45. As Reva Siegel's study of this transition reveals, nineteenth-century judges and legal scholars explained the refusal to intervene in cases of wife beating as a method of protecting marital privacy and promoting marital harmony. See Siegel, "The Rule of Love," supra note 11, at 2142-70. For judicial explanations along these lines, see State v. Oliver, 70 N.C. $60,61-62$ (1874) ("If no permanent injury has been inflicted, nor malice, cruelty nor dangerous violence shown by the husband, it is better to draw the curtain, shut out the public gaze, and leave the parties to forget and forgive."); State $v$. Rhodes, 61 N.C. (Phil. Law) 453, 459 (1868) ("[It] is not, that the husband has the right to whip his wife ... ; but that we will not interfere with family government in trifling cases. ... We will not inflict upon society the greater evil of raising the curtain upon domestic privacy, to punish the lesser evil of trifling violence.").

46. See 9 The American ANd ENGLISH ENCYCLOPfadiA of LAw, supra note 32, at 812 ("The husband is the head of the family. He decides where the family residence shall be, and may change it as often as his pleasure, business or health dictates; and his wife must live where he directs ...."); BRowne, supra note 30, at 15 ("The husband is entitled to select the mutual domicile, where the wife is bound to reside, and whither she is bound to follow him."); KENT, supra note 29, at 218 ("The husband is the best judge of the wants of the family, and the means of supplying them; and if he shifts his domicile, the wife is bound to follow him wherever he chooses to go."); RoDGERS, supra note 31, at 126 ("[T] he husband, being the head of the family in law, has the right to the unmolested possession and control of the person of his wife to the exclusion of all the world. His home is her home; his domicile her domicile."); ScHouler, supra note 19, at 54 ("As there must be a home, so there is also a matrimonial domicile of the parties recognized by universal law. And the husband, as the dignior persona, has the right to fix it where he pleases.... [W]herever he goes she is bound to go 
to prevent her from leaving that household, ${ }^{47}$ and could retrieve her if she did stray, particularly if she had left to go to another man..$^{48}$ In recognition of the legal control that husbands exercised over their wives, common law courts in the nineteenth century presumed that married women acted under the coercion of their husbands and accordingly excused them from liability for a wide range of crimes if committed in their husbands'

likewise...."). Joel Bishop literally naturalized a husband's right to decide where he and his wife would live, explaining that "nature, as well as law, points to the husband as the proper party" to determine marital domicile. "The concurring testimony of the world," he observed, "represents the husband to be the forest oak, and the wife the forest vine, clinging to its bark, and graceful and lovely only while it clings." BISHOP, supra note 31 , at 654 .

Nineteenth-century courts were increasingly willing to consider modifications to this common law right, but only incremental ones. In 1882, for instance, James Schouler observed that "[a] husband would not be permitted to remove his wife to some remote and undesirable place for the sake of punishing or tormenting her, or so as to coinpel her to stay alone where he did not mean to rcside himself." This, he explained, "would not be fixing the matrimonial domicile with honest intent." SCHOULER, supra note 30 , at 65 .

47. See 9 The AMERICAN AND English EnCyclopedia of LAw, supra note 32, at 814 ("The husband as head of the family has a right of gentle restraint over his wife's movements. He may, by reasonable measures, enforce cohabitation and a common residence; he inay lock her up to prevent her from eloping, or going into lewd company and squandering her money ...."); BLACKSTONE, supra note 39 , at $* 433$ ("[T] he courts of law will still permit a husband to restrain a wife of her liberty, in case of any gross misbehaviour."); KENT, supra note 29, at 218 ("[A]s the husband is the guardian of the wife, and bound to protect and maintain her, the law has given him a reasonable superiority and control over her person, and he may even put gentle restraints upon har liberty, if her conduct be such as to require it ...."); MANSFIELD, supra note 29, at 270 ("[I]f [a wife] attempt[s] to leave [her husband], or is guilty of improper conduct, he has a right to control and constrain her liberty; provided always this is done gently and with no violation of the criminal law."); REEvE, supra note 43, at 66 ("[I]t is said, that [a husband] may imprison [his wife] to prevent her going off with an adultercr, and also to prevent her from destroying and squandering his property."); SCHOULER, supra note 19, at 53 ("Marriage necessarily supposes a home and mutual cohabitation. Each party has therefore a right to the society of the other. They married to secure such society. And the obligation rests upon both to live together-or as the expression sometimes goes to adhere.").

48. See 1 Joel Prentiss Bishop, Commentaries on the Criminal Law 739 (Boston, Little, Brown \& Co. 2 d ed. 1858) ("P] [his wife's] locomotion. And the North Carolina court has very properiy held, that he inay lawfully take her by force from the possession of an adulterer."); BRowne, supra note 30, at 17 ("There is no doubt that the husband may forcibly prevent the wife from eloping...."); MANSFIELD, supra note 29, at 270 ("I]f a wife leave her husband, he has a right to reclaim and bring her back."); REEve, supra note 43, at 66 ("This seems to be settled, that if a wife elope and go away from her husband without cause, that the husband inay seize upon her person and bring her home ...."); ScHovler, supra note 19, at 60 ("Strong instances for the exercise of this right [of 'gentle restraint'] occur where the wife has eloped with a libertine and the husband wishes to bring her home, or where she purposes an elopement and he secks to prevent it.").

Common law courts had placed some restraints on the exercise of this authority by the nineteenth century. Tapping Recve's family law treatise, the first published in the United States, explained as early as 1816 that "the court will never take away a wife from a friend to whom she has fled to escape the effects of his brutality, and order her to be delivered to her husband." REEVE, supra note 43, at 66; see also KENT, supra note 29, at 217-18 ("[F]or any unreasonable and improper confinement by [her husband], [a married woman] inay be entitled to relief upon habeas corpus."); ScHOULER, supra note 19, at 60-61 ("Mr. Justice Coleridge, in an English case, observes, that the husband's right inust not be exercised unnecessarily or with undue severity; and that the moment the wife, by her return to conjugal duties, makes the restraint of her person unnecessary, such restraint becomes unlawful."). 
presence. This presumption excluded only the most serious offenses, like treason, murder, and robbery, and crimes understood to be the particular province of women, like keeping a brothel. ${ }^{49}$

The marital rape exemption had deep roots in this legal regime. It was understood, explained, and defended in the context of a wide array of marital status rules that conclusively inferred consent from a person's initial agreement to marry and coverture principles that organized marital status so that husbands exercised control over their wives.

\section{B. The Marital Rape Exemption in Nineteenth-Century Criminal Law}

There was not the slightest suggestion in nineteenth-century case law and treatises that a husband could be prosecuted for raping his wife. Rape laws stated what a "male person" could not do to "any woman, other than his wife." cannot be guilty of a rape upon his own wife," that "a husband does not become guilty of rape by forcing his wife to his own embraces," 52 that rape "may be committed by any male of the age of fourteen or over, not the husband of the female." ${ }^{\text {"T3 }}$ This clear prohibition on prosecution had its intended effect. I have been able to locate no nineteenth-century attempts to

49. See 9 The AMERICAN AND ENGLISH ENCYCLOPfeDIA of LAW, supra note 32, at 826-28; 1 Joel Prentiss Bishop, Commentaries on the Criminal Law 243-49 (Boston, Little, Brown \& Co. 1856); Browne, supra note 30, at 14-15, 26-27; WM. L. CLARK, JR., HAND-BooK OF Criminal LAW 77-78 (St. Paul, West Publishing Co. 1894); MANSFIELD, supra note 29, at 285; RodGers, supra note 31 , at 230-31; 1 Thomas W. Waterman, A Complete Practical Treatise on Criminal Procedure *6-7 (New York, Banks, Gould \& Co. 6th ed. 1853); Francis Wharton, A Treatise on the Criminal Law of the United States 19-23 (Philadelphia, James Kay, Jun. \& Brother 1846).

Common law courts paired this exemption from liability for wives with a rule holding husbands criminally liable for the offenses their wives had committed in their presence. As Joel Bishop explained, a husband was required, on pain of criminal sanctions, "to put forth his marital power to restrain [his wife] from violating the laws." B1SHOP, supra note 44 , at 536 .

50. 2 WATERMAN, supra note 49 , at *304-1 n. 1 (quoting Ohio statute); see also id. at *305-1 n.1 (quoting Oregon law defining rape as an act committed by "'any male person"" against "'any woman other than his wife"').

51. Oliver L. Barbour, The Magistrate's Criminal Law 66 (Albany, Wm. \& A. Gould \& Co. 1841).

52. 2 Bishop, supra note 48 , at $623-24$.

53. MCCLAIN, supra note 43, at 429; see also id. at 207-08 ("The consent of the wife to sexual connection with the husband having been given by the act of marrying, he is not guilty of an assault in having such connection."); 3 Joseph ChitTy, A Practical Treatise on the Criminal Law *811 (Springfield, G. \& C. Merriam 4th Am. ed. 1841) ("A man cannot, indeed, be himself guilty of a rape on his own wife ...."); CLARK, supra note 49, at 190 ("It is lawful for a husband to have carnal knowledge of his wife, and the fact that he uses force does not make him guilty of rape."); 1 WM. L. Clark \& WM. L. Marshall, A Treatise on the LaW of Crimes 645 (1900) ("[A] man cannot be guilty of this offense [rape] by having carnal knowledge of his wife, and it can make no difference that he does so by force and against her will."); Ira M. Moore, A Practical Treatise on Criminal Law, and Procedure in Criminal Cases, Before Justices of the Peace and in Courts of ReCORD in the STATE of Illinols 306 (Chicago, Callaghan \& Co. 1876) ("The Husband Cannot be Guilty of Rape upon his own Wife....”); WHARTON, supra note 49, at 293 ("[A] husband cannot be convicted of the offence [of rape]...."). 
try a husband for personally raping his wife, ${ }^{54}$ and only one prosecution, Frazier $v$. State,$^{55}$ from early in the twentieth century. ${ }^{56}$ The Texas court that heard Mr. Frazier's appeal in 1905 reversed his conviction for assault with attempt to rape, which is not surprising. ${ }^{57}$ The unexplained-and unique-puzzle of the Frazier case is how it reached a trial court and a jury in the first place.

The history of marital rape necessarily contains large silences because of this absence of prosecution. Cases left uninvestigated and unbrought are much harder to reconstruct than the concrete proceedings of trials and appeals. As a consequence, the record of the marital rape exemption has, on occasion, bizarre locations. This section examines laws, legal treatises, and cases, but none of these sources were responding to, commenting on, or deciding actual marital rape suits; they addressed the exemption in some other, less direct way. A large proportion of the nineteenth-century judicial opinions that discussed the marital rape exemption, for instance, revolved around the question of whether a rape indictment, in a case with no evidence of a marital relationship between victim and defendant, still had to state that the victim and defendant were not married to each other. Some nineteenth-century courts actually

54. Husbands were successfully prosecuted for rapes committed on their wives, when they were not the direct perpetrators of the rape but had helped or forced another man to commit it. See infra text accompanying notes $78-97$.

In addition, at least one husband in England was prosecuted in the nineteenth century for forcibly sodomizing his wife. See Regina v. Jellyman, 173 Eng. Rep. 637, 637 (1838) ("The prisoner was indicted for having committed an unnatural offence with his own wife .... It was stated by the wife of the prisoner, that he committed the offence while in bed with her, and that she resisted as much as she could ...."). The court instructed the jurors to acquit if they found that the wife had actually consented to the sodomy. The jury returned a verdict of not guilty. See id. (recording jury instruction that: "[T]he wife, if she consented, would be an accomplice [to sodomy], she would require confirmation .... If you either disbelieve the evidence, or believe the prosecutrix did not resist, you ought to acquit; it was her duty to have resisted such an attempt to the utmost."); see also MOORE, supra note 53, at 307 \& n.3 (citing Jellyman); 1 Thomas W. Waterman, A Complete Practical Treatise on Criminal Procedure 185 (New York, Banks \& Bros. 7th ed. 1860) (discussing Jellyman).

55. 86 S.W. 754 (Tex. Crim. App. 1905).

56. At trial, Mason Frazier was found guilty of assault with attempt to rape. The evidence indicated that Emma Frazier, his wife, had informed her husband that she no longer wanted to have marital intercourse with him, had moved into a separate bedroom, and had unsuccessfully sought a divorce. See id. at 754-55. Mr. Frazier was convicted based on evidence that:

On the occasion of the alleged assault [he] entered [his wife's] room, and rather vigorously insisted upon what he believed to be his rights as a husband. She resisted, and fled into the room where the boys were sleeping. Appellant followed her in there, and again renewed his efforts. She finally escaped, however, and the matter ended. Id. at 755 .

57. The Texas Court of Criminal Appeals relied on a long line of precedent in finding that Mr. Frazier's conduct did not constitute "a violation of the law." Id. at 755. As it noted, "in all the cases it is said, so far as we are aware, wherever the question has been adjudicated, that the husband cannot be himself guilty of actual rape upon his wife." Id.; see also id. ("So far as we are aware, all the authorities hold that a man cannot himself be guilty of actual rape upon his wife ...."); id. ("[W]e are aware of no case holding that the husband can be guilty of the offense where he himself is the actual party to the intercourse."). 


\section{reversed rape convictions because the indictment had failed to explicitly indicate that the victim was not the defendant's wife. ${ }^{58}$}

58. These cases often relied on United States $v$. Cook, 84 U.S. (17 Wall.) 168 (1872), which held that an explicit statement of non-applicability was required in an indictment where the statutory exemption at issue constitutcd an element of the crime, rather than simply a defense to it, see id. at 173-74. The courts that considered this question in the context of the marital rape exemption wcre divided.

Some held that the marital rape exemption was a constitutive element of the crime of rape, so that an indictment could not give sufficient notice to the accused of the offense charged without specifically indicating that the exemption did not apply. See Parker v. Territory, 59 P. 9, 10 (Okla. 1899) ("[A]s thc allegation that the prosecutrix was not the wife of the accused was a material and necessary part of the definition of the offense,... we think there is no doubt that the failure to charge this fact in the indictment was fatal to the indictment ...." (citing Cook)); Young v. Territory, 58 P. 724, 725 (Okla. 1899) ("[Oklahoma's rape statute] cannot be read, and eliminate the clause 'not the wife of the perpetrator.' This [clause] is not a matter of exeuse for the defendant, ... but is a nccessary and essential element of the crime itself, which must be established by the prosecution ...." (citing Cook)); Dudley v. State, 40 S.W. 269, 269 (Tex. Crim. App. 1897) ("[I]n cases of assault with intent to rape the indictment must negative the fact that the girl was the wife of the accused."); Edwards v. State, 39 S.W. 368, 368 (Tex. Crim. App. 1897) ("[P] art of the definition [of raping a girl under 15], is the fact that the parties were not man and wife. ... [A]ll of the constituent elements that go to make up rape, exccpt penetration, must be alleged and proved in an assault with intent to rape ...."); Rice v. State, $38 \mathrm{~S} . \mathrm{W}$. 801, 802 (Tex. Crim. App. 1897) ("IT]he words 'other than the wife of the person' occur in the body of the enacting clause.... [It] is a part of the act itself, and, under the rule heretofore laid down, the indictment should negative the fact that the alleged injured female was the wife of the defendant.").

Other courts refused to overturn rape convictions where the indictment failed to specifically indicate that the victim was not the defendant's wife. See People v. Estrada, 53 Cal. 600, 600 (1879); State v. Terry, 20 N.C. (3 \& 4 Dev. \& Bat.) 240, 242 (1838); MCClaIN, supra note 43, at 434 ("It is not necessary to allege in the [rapel indictment that the woman is not the wife of the defendant ....."); see also State v. Halbert, 44 P. 538, 538 (Wash. 1896) (holding that an indictment for sexually abusing a female child, whose last name was the same as the defendant's, did not need to state that the child was not the defendant's wife). These decisions were generally careful to stress that the indictments at issue indicated, albeit indirectly, that the victim was, in fact, not the wife of the accused. See State v. White, 25 P. 33, 35 (Kan. 1890) ("[I]f Lottie Linden had been the wife of the defendant Charles W. White, her name would have been White, and the intercourse charged would not have been a 'crime' or 'rape' nor committed 'unlawfully and feloniously,' as charged ....."); Commonwealth v. Scannel, 65 Mass. (11 Cush.) 547, 548 (1853) ("The indictment, charging as it does, that the defendant did ravish one Mary Moran, a person of different name and without further description, corresponds to the usual precedents in this respect, and is well enough."). Some of these courts also specifically characterized the marital exemption as a defense to rape, rather than an element of the crime, which placcd the burden on the defendant to bring forth evidence that he was married to the victim. See Commonwealth v. Fogerty, 74 Mass. (8 Gray) 489, 491 (1857) ("[A1 party indicted [could always] show, in defence of a charge of rape alleged to be actually committed by himself, that the woman on whom it was charged to have becn committed was his wife. But it is not necessary to negative the fact in the indictment."); State v. Williams, 23 P. 335, 337 (Mont. 1890) ("The essential element of the offense is the outrage to the person and feclings of the female .... The offense would exist in an act of sexual intercourse committed with any female, under any of the [statutoryl circumstances ..., with the exception, not of a elass of females, but of a single individual, viz., the wife of the perpetrator."); State v. Williamson, 62 P. 1022, 1023 (Utah 1900) ("[T]t is not necessary, under our statute, to show in the information that the person ravished was not the wife of the defendant. The statute contains no provision or exception requiring it. ... The party indieted, however, may show in his defense that the alleged act was committed with his wife."); Francis J. LipPITT, Criminal Law as ADMINISTERED in MasSachusetTs 261 (Boston, Houghton, Osgood \& Co. 1879) ("The [rape] Indictment need not allege ... that the female was not his wife. ... This can be shown in defence."). 
The notable contrast between wives' categorical exemption from rape statutes and the protection against rape (nominally) accorded to other highly vulnerable classes of women also helps illustrate the exemption's deep roots in nineteenth-century law. It was a well-established proposition in nineteenth-century treatises that prostitutes and concubines fell within the purview of rape statutes, even if actual conviction was unlikely since the defendant could present evidence of the victim's occupation to the jury..$^{59}$ Legal writers explained that the concern of rape laws centered, not on the status of the victini, but on the fact that the act in question was "against the will of the fenrale on whom it is committed. ${ }^{.60}$ On this theory, prostitutes and concubines were fully covered by rape laws; ${ }^{61}$ a nran accused of raping a prostitute or concubine could offer reputational evidence against his alleged victim only because such evidence was understood to speak to the likelihood that the woman had in fact consented. ${ }^{62}$ Yet

59. The common law rule that a man could be prosecuted for raping a prostitute actually dates as far back as 1631, when the King's Bench in England noted in Lord Audley's Case that a rape conviction would stand, notwithstanding proof "that the party ravished [was] of evil fame, and of an unchaste life." The Trial of Mervin Lord Audley, Earl of Castlehaven, for a Rape and Sodomy (1631), reprinted in 3 A Complete Collection of State Trials 401, 414 (T.B. Howell ed., London, T.C. Hansard 1816) [hereinafter Lord Audley's Case]. As the opinion explained, "[t]he Judges resolve it to be a Rape, though committed on the body of a common strumpet; for it is the enforcing against the will which makes the Rape; and a common whore nuay be ravished against her will, and it is Felony to do it." Id.

60. BARBOUR, supra note 51 , at 65 .

61. See id. ("N]) will it be any excuse [in a rape case that the victim] ... was a common strumpet, or the concubine of the ravisher; for she is still under the protection of the law, and may not be forced."); CHITTY, supra note 53 , at $* 811$ ("Formerly it was said to be no rape for a man to have forcible knowledge of his own concubine, but the law now presumes the possibility of her return to virtue.") (citations omitted); CLARK, supra note 49, at 190 ("The fact that the woman is a common prostitute, or the man's mistress, does not make the act any the less rape, if force, actual or implied, is used; for the carnal knowledge is unlawful, and forcible unlawful carnal knowledge of any woman is rape."); CLARK \& MARSHALL, supra note 53, at 646 ("Subject to this qualification [for wives], any female may be the subject of rape. It is not necessary .... that she shall have been chaste. ... [Unchastity] does not, as a matter of law, prevent the intercourse from being rape, if it was in fact accomplished by force and without her consent."); DEAN, supra note 36, at 25 ("The crime of rape may be committed upon a virgin, a single or married woman, or even upon a prostitute. The latter being also under the protection of the law."); MCCLAIN, supra note 43, at 442 ("[T] he want of chastity of the female is no defense, for the crime of rape may be committed upon a prostitute or upon the mistress of the assailant ...."); MoORE, supra note 53, at 304 ('It is, however, no excuse for the party committing the offense of rape that the woman was a strumpet or the concubine of the ravisher, for she is still under the protection of the law and may not be forced."); 2 WATERMAN, supra note 49 , at *306$1 \mathrm{n} .1$ ("[A] common strumpet... is still under the protection of the law, and may not be forced. Neither is it even any justification, that [the victim] was a concubine to the ravisher himself; for a woman may forsake her unlawful course of life ...."); WHARTON, supra note 49, at 296 (similar).

62. See BARBour, supra note 51, at 67 ("If the prosecutrix be of good fame ... these and the like circumstances give greater probability to her evidence; but on the contrary, if she be of evil fame... these and the like circumstances carry a strong but not a conclusive presumption that her story is fictitious.'); ChitTY, supra note 53 , at $* 812$ (similar); 2 Joel Prentiss Bishop, CoMmentaries on THE CRIMINAL LAw 619 (Boston, Little, Brown, \& Co. 6th ed. 1877) ("This offence may be committed as well on a woman unchaste, or a common prostitute, as on any other female. In matter of evidence, however, want of chastity may, within recognized limits, be shown as rendering it more probable that 
nineteenth-century case law and treatises never indicated that analogous reasoning might suggest that husbands should be criminally liable for raping their wives. To the contrary, leading treatises reviewed the contrasting rights of prostitutes and wives side-by-side without any apparent qualms, noting, for example, that rape "may be committed as well on a common prostitute, as on any other female. But a husband does not become guilty of rape by forcing his wife to his own embraces."63

The reasons cited to explain and justify the exemption in nineteenthcentury authoritative legal sources originated in the work of Sir Matthew Hale, a former Chief Justice of the Court of King's Bench in England. Hale's seminal treatise, the History of the Pleas of the Crown, ${ }^{64}$ was first published in England in 1736 and became extraordinarily influential in American legal circles almost immediately thereafter. ${ }^{65}$ Even more than a century after Hale's work appeared, American treatises and case law had not supplemented Hale's arguments for the marital rape exemption with alternate theories of their own.

As an initial matter, this reliance on Hale suggests how secure nineteenth-century legal authorities took the criminal exemption to be. Indeed, one of the most striking aspects of the nineteenth-century "debate" over marital rape is how little debate there actually was in terms of direct exchange between the exemption's legal champions and its critics. Although, as we will see, some late nineteenth-century courts did modify the

she consented."); CLARK, supra note 49, at 190 ("The fact, however, that the woman was a prostitute, or of unchaste character, may always be considered in determining whether she consented or not, as a prostitute would be more apt to consent than a chaste woman."); CLARK \& MARSHALL, supra note 53, at 646 ("The fact that she was not chaste may aid, as a matter of evidence, in showing that she consented ....."); DEAN, supra note 36, at 24 ("II]t may . . . be shown that she ['the prosecutrix'] is a common prostitute, this fact, if true, tending to repel the allegation of force, and laying a foundation for inferring assent on her part."); MCCLAIN, supra note 43, at 442 ("While the want of chastity of the female is no defense, ... the bad character of the prosecutrix as to chastity is material as tending to show that the evidence of want of consent is not sufficient."); MOORE, supra note 53, at 302-03 ("For the purpose of raising the presumption that the woman consented, it may be shown that she bore a notoriously bad character for want of chastity and common decency; that she was in fact a common prostitute; or . . the concubine of the ravisher; or had voluntarily had connection with him."); 2 WATERMAN, supra note 49 , at $* 307$ to $307-1$ ("Nor is it any defence that she is a common strumpet .... But... though in itself no defence, it is most material for the defendant, and it is permitted to him to show the fact, to throw a doubt upon her statement that the connexion was had against her will."); WHARTON, supra note 49, at 296 ("All these latter circumstances [being 'a common strumpet' or 'a concubine to the ravisher'], however, are material to be left to the jury in favour of the party accused, more especially in doubtful cases, and where the woman's testimony is not corroborated by other evidence.").

63. 2 BisHOP, supra note 48 , at 623-24.

64. 1 Matthew Hale, The History of the Pleas of the Crown (Philadelphia, Robert H. Small 1st Am. ed. 1847) (1736).

65. See Cornelia Hughes Dayton, Women Before the Bar: Gender, Law, and Society IN CONNECTICUT, 1639-1789, at 246-47 (1995); Sharon Block, Coerced Sex in British North America, 1700-1820, at 179-80, 189, 195 (1995) (unpublished Ph.D. dissertation, Princeton University) (on file with author). 
law's treatment of marital rape as it affected the terms on which divorce was available ${ }^{66}$ lawyers and judges saw no need to respond to opposing arguments in the criminal arena - the core of the exemption, rather than its peripheries. In these sources, the criminal exemption remained a given. Treatise writers and judges saw no threat meriting a rethinking of the claims on which they had relied for over a hundred years.

Another explanation for this reliance on Hale, though, one equally important to understand, is that these sources depended on Hale so heavily because his arguments, grounded in principles of marital status law and common law coverture, still seemed so convincing to them. In the nineteenth century, American judges and lawyers who confronted the marital rape exemption routinely cited Hale's argument from irretractible consent. Hale's explication read, in full, as follows: "But the husband cannot be guilty of a rape committed by himself upon his lawful wife, for by their mutual matrimomal consent and contract the wife hath given up herself in this kind unto her husband, which she cannot retract." ${ }^{167}$ The statement included no supporting citations, and this appears not to have been an oversight. Even scholars who believe that ample common law authority already sanctioned the marital rape exemption when Hale wrote, ${ }^{68}$ posit that the theory of irretractible consent originated with him. ${ }^{69}$

66. See infra Part IV.

67. HALE, supra note 64 , at 629 .

68. The earliest roots of the marital rape exemption are murky. The rule may be linked to the concept of "conjugal debt" in medieval moral theology and the law of the church. This concept, derived from Biblical statements on marriage, held that "both husband and wife had a duty to perform sexually at the request of their mate." Elizabeth M. Makowski, The Conjugal Debt and Medieval Canon Law, 3 J. Medieval Hist. 99, 99 (1977); see also 1 Cor. 7:4 ("A wife has no authority over her body, but her husband; likewise the husband has no authority over his body, but his wife. You must not refuse each other ...."). A husband or wife could not unilaterally terminate this conjugal debt, even by joining a religious order that prohibited sexual intercourse. See Makowski, supra, at 109. A spouse lost his right of sexual access only if he committed a sin like adultery. See id. Some historians of the middle ages have presented the doctrine of conjugal debt as evidence "of female equality in marital sexual relations," arguing that "[m]edieval canonists' opinions about the sexual equality of married men and women formed an integral part of the process that slowly led to a grudging recognition that equity requires that men and women be treated equally in other spheres of life as well." JAMES A. BRUNDAGE, Sexual Equality in Medieval Cannon Law, in SEx, LAw ANd MarRiage IN The Middle Ages 66, 70, 72 (1993); see also Makowski, supra, at 99 (describing conjugal debt as an "equal opportunity concept"). The history of the marital rape exemption in the nineteenth and twentieth centuries suggests that these scholars may have read too much into the fact that the conjugal debt concept formally bound a husband as much as his wife. Tellingly, almost every marital rape statute has been made formally gender-neutral in the last twenty-five years, but the change has had essentially no impact on the genderspecificity of the law's operation. See infra text accompanying notes 444-447, 463-476.

69. See David Lanham, Hale-Misogyny and Rape, 7 CRIM. L.J. 148, 155 (1983) ("While it seems clear that there was ample authority for the fact of marital immunity in rape, the theoretical basis of the immunity does seem to be Hale's own creation."). Lanbam is very sympathetic to Hale, despite the impression that the title of his article might convey. He argues, for instance, that Hale invented his own explanation for the marital rape exemption because "Hale's attitude towards marital immunity was more favourable to women than any authority which he could have cited. Instead of giving a reference 
Yet treatises and cases would repeat Hale's words, virtually verbatim, throughout the nineteenth century, often as the only explanation they offered for the exemption: "A man cannot be guilty of a rape upon his own wife; for the matrimonial consent cannot be retracted," they noted. ${ }^{70}$ "[T]he husband of a woman cannot himself be guilty of an actual rape upon his wife, on account of the matrimonial consent which she has given, and which she cannot retract."71 Several aspects of Hale's theory suggest why it proved so compelling.

Hale's understanding of presumed legal consent made enormous sense in the framework of nineteenth-century marital status law. As we have seen, all of these status rules operated automatically, subjecting every husband and every wife to predetermined constraints without permitting individual negotiation or waiting for individual consent. These status rules, moreover, remained in place as long as the marital relation itself: Opting-out was impossible while one's marriage lasted (and the prospects for securing a divorce were very limited). Whether a husband or wife actually supported these rules, or would have liked to contract around them, was irrelevant as a matter of law. The only occasion for actual agreement was a person's decision to marry in the first place. Hale's theory applied this same understanding of legal consent to one of the many status rules that organized the marital relation at common law, namely, the rape exemption. His work explained that, in this context as

or series of references which would have given a misleading impression of his view of the law, he inserted his statement of marital immunity." Id. at 153-54.

Cornelia Hughes Dayton's study of court records in colonial Connccticut also suggests that Hale's writing on rape did not simply record the law as it was then understood, but instead was deeply influenced by Hale's own view of how rape law should be organized and explained. See DAYToN, supra note 65. Dayton studied, not the marital rape exemption, but another famous statcment from Sir Hale on rape, his warning that:

It is true rape is a most detestable crime, and therefore ought severely and impartially to be punished with death; but it must be remembered, that it is an accusation easily to be made and hard to be proved, and harder to be defended by the party accused, tho nevcr so innocent. HALE, supra note 64, at 635. Her research indicates that Hale's suspicion about the veracity of women who brought rape charges did not correspond to the law in colonial America, at least, at the time that he wrote. To the contrary, Dayton reports that courts in seventeenth-century Connecticut operated on the presumption that women's charges of rape were to be believed. See DAYTON, supra note 65, at 31-32, 234-40. The presumption eventually changed, by the middle of the eightcenth century, because judges and lawyers who had been influenced by reading Hale changed their local law to reflect his warning. See id. at 60-61, 232, 234, 246-47. This history suggests that contemporaries did not understand Hale's writing on rape simply as a positive account of the law, but rather took it, at least in some respects, as a normative argument.

70. BARBour, supra note 51, at 66 ; see also CHITTY, supra note 53 , at $* 811$ ("A man cannot, indeed, be himself guilty of a rape on his own wife, for the matrimonial consent cannot be retracted ...."); MOORE, supra note 53, at 306 ("The Husband Cannot be Guilty of Rape upon his own Wife for the matrimonial consent cannot be retracted ....").

71. State v. Haines, 25 So. 372, 372 (La. 1899); see also 2 WATERMAN, supra note 49 , at *306-1 n.1 (same statement). 
elsewhere, a married person's original agreement to marry justified a legal presumption of permanent and irretractible consent to marital status law.

It was, accordingly, important that Hale's consent theory, and the marital rape exemption, did not cover forced marriages, where the wife had been unlawfully compelled to wed. Hale himself explicitly carved out an exception for these women, noting that their putative husbands could be prosecuted for raping them. ${ }^{72}$ Nineteenth-century treatises, in turn, adopted the point. As Thomas Waterman explained in 1853, the agreement to marry was "in reality nothing more, nor less, than a contract between two parties." Because "a contract implie[d] mutual consent, there [could], of course, be no contract, when either party with[held] consent, or when consent [was] extorted by duress." The victim of a forced marriage had never freely agreed to marry, hence she was not legally married, hence her consent to the operation of marital status law could not be presumed. ${ }^{73}$

I want to stress, however, that Hale's theory generally did not concern itself with a wife's actual state of mind. To be sure, his explanation depended on the proposition that a woman had actually agreed to her marriage, under circumstances free from legally cognizable force, duress, or fraud. But after a woman had made that decision, Hale's theory no longer turned on what a woman actually wanted or would agree to if asked. Consider Hale's last clause: "But the husband cannot be guilty of a rape committed by himself upon his lawful wife, for by their mutual matrinonial consent and contract the wife hath given up herself in this kind unto her husband, which she cannot retract.". ${ }^{\prime 4}$ This clause suggested that there might be situations in which a married woman would want to retract her consent to marital intercourse. Hale's statement, in other words, acknowledged the potential divergence between a wife's actual state of mind at any particular moment during a marriage, and the legal rule conclusively inferring consent from her initial agreement to marry. More precisely, it acknowledged this divergence and enforced the legal presumption of consent. In doing so, it reconciled the theory behind the

72. See HALE, supra note 64 , at 629-30. Hale also argued that victims of forced marriages who retroactively gave their consent to the abduction could shield their husbands from rape prosecution. See id. at 629,633 .

73. 2 WATERMAN, supra note 49 , at $* 306-1 \mathrm{n} .1$; see also Barbour, supra note 51 , at 72 ; CHITrY, supra note 53 , at $* 811$.

Blackstone made a similar argument to explain why a wife could properly testify against her husband in cases of forced marriage:

in this case she can with no propriety be reckoned his wife; because a main ingredient, her consent, was wanting to the contract: and also there is another maxim of law, that no man shall take advantage of his own wrong; which the ravisher here would do, if by forcibly marrying a woman, he could prevent her from being a witness, who is perhaps the only witness, to that very fact.

BlaCkstone, supra note 39 , at $* 431$.

74. HALE, supra note 64 , at 629 (emphasis added). 
marital rape exemption with that explaining the legitimacy of marital status law generally.

Hale's argument for the marital rape exemption also resonated deeply with the coverture principles that shaped the content of most marital status rules in the nineteenth century. His explanation started by noting the "mutual matrimonial consent and contract" of husband and wife, evidenced by their shared agreement to marry. ${ }^{75}$ But it proceeded to outline only the obligation that a wife owed her husband: "for by their mutual matrimonial consent and contract the wife hath given up herself in this kind unto her husband."76 In other words, Hale presented a couple's mutual decision to marry as grounds for subjecting wives and husbands to very different obligations and rights. Both a wife and her husband agreed to marry, but where this agreement gave the husband a right of sexual access to his wife, it bestowed an obligation on the wife to submit. One might think, as a purely theoretical matter, that this explicit sex-based differentiation required justification. But in historical context, of course, such an explanation could easily be understood as superfluous. Hale's theory accorded with coverture principles that generally subjected wives to a wide array of limitations and obligations that husbands did not bear. This is not to say that the relationship between husband and wife was not a reciprocal one at common law. It was; a wife had the right to support and protection from her husband. ${ }^{77}$ But while the marital relationship was reciprocal, it was also explicitly hierarchical. Wives were vastly more constrained; they surrendered many more legal rights by marrying. The marital rape exemption, with its unequal demands on husband and wife, was just one more example of coverture principles at work. And the widespread commitment to the operative tenets of coverture was another reason that Hale's irretractible consent theory struck authoritative legal sources in the nineteenth century as so satisfactory.

When nineteenth-century cases and treatises considered the marital rape exemption, they did not limit themselves to citing Hale's consent theory, however. They often spent just as much time, or more, articulating what I call a "third-party caveat" to the marital rape exemption, also derived from Hale and also meant to legitimate a wife's subordination to her husband. This caveat stated that the marital rape exemption was a personal privilege. It only covered acts that a husband personally committed on his wife; it did not reach cases in which a husband had allowed, or forced, another man to rape his wife. Why were so many pages devoted to

75. Id. (emphasis added).

76. Id. (emphasis added).

77. See 9 THE AMERICAN AND ENGLISH ENCYCLopedia OF LAW, supra note 32, at 815-16, 829. 32; Peregrine Bingham, The Law of Infancy and Coverture 187-88 (Exeter, George Lamson Ist Am. ed. 1824); Bishop, supra note 32, at 31-32; BlaCKSTONE, supra note 39, at *430; KENT, supra note 29, at 176-79; MANSFIELD, supra note 29, at 284-305; SCHOULER, supra note 19, at 76-77. 
stating this limit on the marital rape exemption? The effort indicates, first, what was and was not understood to be contestable. Cases and treatises touching upon the marital rape exemption in the nineteenth century would often cite Hale's irretractible consent theory, but would generally do little else to confirm the existence and soundness of the ban on prosecuting a husband for raping his wife. The lack of standard forms of support, like case citations, in discussions of the marital rape exemption indicated its status as an understood baseline. In contrast, judges and lawyers clearly felt that they had to do more to explain and justify the third-party caveat, perhaps because the caveat functioned to limit a husband's control over his wife's person. Even though every case and treatise that considered the issue endorsed the caveat, ${ }^{78}$ the rule had to be defended rather than just stated.

More fundamentally, though, the emphasis on the third-party caveat reinforced the point that the marital rape exemption drew the line between legal and illegal intercourse so that it depended solely on whether a woman was married to her sexual partner, and not on her consent. In nineteenth-century jurisprudence, all sex outside of marriage, whether consensual or not, was illicit by definition and formally criminalized in fornication and adultery statutes. ${ }^{79}$ The marital rape exemption reflected and extended this dichotomy by making marital intercourse legal by definition. ${ }^{80}$ The third-party caveat helped to further underscore this demarcation by stressing that the marital rape exemption did not cover any sex outside of marriage, even if accomplished at a husband's command.

Structuring the legality of sex so that it turned exclusively on whether a woman was married to her sexual partner was crucially important because it obscured how the marital rape exemption made a wife's position resemble that of a prostitute. The comparison, which nineteenthcentury feminists would press aggressively, ${ }^{81}$ appears to have made the exemption's defenders anxious as far back as Hale. Prostitutes were generally thought to be socially degraded in ways that wives were not. But no overwhelming logic presented itself in this context to explain the

78. See sources cited infra notes 79-97.

79. See ClaRK, supra note 49, at 312-19; ClARK \& MARSHALL, supra note 53, at 164-65; Constable of the Commonwealth, Abstract of Criminal Laws of Massachusetts 80-81 (Boston, Wright \& Potter rev. ed. 1869); Eugene L. Gross, A Digest of the Criminal Laws of IllıNo1s 53 (Springfield, Illinois Journal Co. 1868); LIPPITT, supra note 58, at 130-34; EDWARD Livingston, A System of Penal LAW for the UNited States of AMERica 87-88 (Washington, Gales \& Seaton 1828); 2 MCCLAIN, supra note 43, at 248-60, 286-88; MOORE, supra note 53, at 44345; M. WarRen, OHIo Criminal LaIV and Forms 329-30, 336-38 (Cincinnati, Wrightson \& Co. 1856); WHARTON, supra note 49, at 556-59.

80. In fact, this dichotomy was never as complete as discussion of the marital rape exemption in the nineteenth century suggested. Many states prohibited sodomy between husband and wife. See, e.g., MOORE, supra note 53, at 306-07; WATERMAN, supra note 54, at 184-86. However, lawyers and judges never acknowledged this point in explaining the exemption's treatment of licit and illicit sex.

81. See infra text accompanying notes 184-209, 261-264. 
difference in the work performed. After all, a husband had a duty to support his wife at common law, ${ }^{82}$ and the exemption gave him a legal right to take sex in return. If a wife had extramarital relations (against her husband's wishes), the common law permitted the husband to collect civil damages from the other man, financially compensating him for "the invasion of his exclusive right to marital intercourse with his wife."

Rather than attempt to substantively distinguish the terms on which wives and prostitutes provided sexual services, authoritative legal sources, with the help of the third-party caveat, separated the two sets of women by reference to whether or not they were married to the men who had sex with them. Consider Hale's explanation of the caveat:
$A$. the husband of $B$. intends to prostitute her to a rape by $C$. against her will, and $C$. accordingly doth ravish her, $A$. being present, and assisting to this rape ... [T] his was a rape in $C$. notwithstanding the husband assisted in it, for tho in marriage she hath given up her body to her husband, she is not to be by him prostituted to another.... [T] also guilty as a principal in rape, and therefore, altho the wife cannot have an appeal of rape against her husband, yet he is indictable for it at the king's suit as a principal. ${ }^{84}$

In Hale's account, the difference between a wife and a prostitute is explained solely as a matter of jurisdiction. Intercourse with one's husband was the obligation of wives; it was part of what being a wife signified. In contrast, adultery (forced or not) fell within the purview of prostitutes. When a woman agreed to marry, she agreed to be a wife and, accordingly, not a prostitute. All this meant in practical terms, though, was that sex with one's husband (consensual or not) was licit and socially sanctioned, and sex with a man other than one's husband (consensual or not) was illicit and socially stigmatized. ${ }^{85}$

82. See supra note 77 and accompanying text.

83. Bigaouette v. Paulet, 134 Mass. 123, 125 (1883); see also Bedan v. Turney, 34 P. 442, 443 (Cal. 1893) ("Her sexual intercourse with another is an invasion of his rigbts . . . As the right belongs to the husband, it is no defense to his action for rcdress that its violation was by the consent or procurement of the wife, for sbe is not competent to give such consent . . ..”); Browning v. Jones, 52 Ill. App. 597, 604 (1893) ("[U]nder and by virtue of [the marriage contract] the husband had acquired a right and interest in, what is termed in law, consortship, ... which is the converse of a dishonored bed, the destruction of domestic comfort, of suspicion cast upon the legitimacy of offspring ...."); Wales v. Miner, 89 Ind. 118, 125 (1883) ("As against the rights of the husband, tbe wife is incapable of consenting to her seduction."); 9 THE AMERICAN AND ENGLISH ENCYCLOPfDIA OF LAW, supra note 32, at 834 ("Inasmuch as the husband has the exclusive right of sexual intercourse with his wife, necessarily he has a right of action against anyone who commits adultery with her."); ReEvE, supra note 43 , at 63-64; SCHOULER, supra note 19 , at 109.

84. HALE, supra note 64, at 629 (emphasis added).

85. Although Hale seems to have devised the argument from prostitution to explain the thirdparty caveat, the caveat itself appeared in the common law a century before his treatise was published. In Lord Audley's Case, tried at the King's Bench in England in 1631, the defendant, Mervin Lord Audley, Earl of Castlehaven, was found guilty of committing "a Rape upon his own wife; for holding 
Nineteenth-century treatises and case law took care to note the thirdparty caveat to the marital rape exemption, often citing Hale's reasoming as an explanation. A husband could be found guilty of rape "as a principal in the second degree," treatise writers observed, "by assisting another person to commit a rape upon his wife; for though, in marriage, the wife has given up her body to her husband, yet he cannot compel her to prostitute herself to another."86 Indeed, this caveat actually led to trial judgments where husbands were found guilty of aiding in the rape of their wives by other men. Consider two of the cases that reached a state supreme court. ${ }^{87}$ While there is no evidence to suggest that these cases were representative of prosecutions under the third-party caveat, they are instances in which a nineteenth-century court had serious occasion to discuss, and explain, why a husband could be convicted as an accomplice to a rape committed on his wife.

People v. Chapman, ${ }^{88}$ the earlier of the two cases, was decided by the Supreme Court of Michigan in 1886. Under a statute rendering all persons who had aided, assisted, or abetted in the commission of a crime liable to punishment as principals, Jeremiah Chapman had been tried and convicted in the rape of his wife, Maggie Chapman. The testimony of Mrs. Chapman and of the actual perpetrator of the offense, James Reagan, indicated that Mr. Chapman had entered into an arrangement with Reagan, whereby Mr. Chapman promised to pay Reagan twenty-five dollars in

her by force, while one of his minions forcibly, against her will, had carnal knowledge of her." Lord Audley's Case, supra note 59, at 401. Under English law, an accomplice or accessory to a felony was considered a principal and subject to the same penalty as the person who actually committed the crime, here a capital penalty for rape. See id. at 401, 416. The judges who decided Lord Audley's Case did not offer any explanation for their decision, beyond the fact that they found that the defendant had indecd committed the acts charged. See id. at 416; see also id. at 411 (wife's testimony); id. at 413 (servant's confession that he raped Lord Audley's wife at Lord's insistence). Indeed, the decision did not even mention the marital rape exemption as a background condition to be kept in mind.

86. 2 WATERMAN, supra note 49, at *306-1 n.1 (emphasis added; original emphasis omitted). For other endorsements of the third-party caveat, see Commonwealth v. Murphy, 84 Mass. (2 Allen) 163, 164-65 (1861); Commonwealth v. Fogerty, 74 Mass. (8 Gray) 489, 491 (1857); Strang v. People, 24 Mich. 1, 13 (1871); Parker v. Territory, 59 P. 9, 10 (Okla. 1899); Young v. Territory, 58 P. 724, 725 (Okla. 1899); 9 THE AMERICAN AND ENGLISH ENCYClOPfDIA OF LAW, supra note 32, at 807; BARBour, supra note 51 , at $66 ; 2$ Bishop, supra note 48 , at 624 ; CHITTY, supra note 53 , at $* 811$; ClARK, supra note 49, at 190-91; ClARK \& MARShall, supra note 53, at 645-46; DEAN, supra note 36 , at 24; LippitT, supra note 58, at 261; MCClaIN, supra note 43, at 430; Moore, supra note 53, at 306; WhARTON, supra note 49, at 293.

87. At least one other husband in the nineteenth century appealed his conviction as an accomplice in the rape of his wife to a state supreme court. State v. Haines, 25 So. 372 (La. 1899), endorsed the third-party caveat to the marital rape exemption as a general matter, see id. at 372 , but limited the caveat's scope to exclude cases, like Haines itself, in which: (1) there was no evidence that the man who had actually engaged in the sexual intercourse had been forced to do so, against his will, by the husband; and (2) this actual perpetrator had nonetheless becn acquitted of rape by the time the state's case against the husband went to trial, see id. at 373 . The court reasoned that "[o]ne cannot be guilty of aiding and abetting the perpetrator of a crime without its first being shown that the crime has been actuaily committed by another." Id.

88. 28 N.W. 896 (Mich. 1886). 
return for Reagan's agreement to seduce Mrs. Chapman so that her husband could catch the couple in bed and use that evidence to obtain a divorce for adultery. Mrs. Chapman, however, resisted Reagan's advances, and he proceeded to rape her. As Reagan knew, Mr. Chapman was in an adjoining room at the time, watching and listening to all of this through a hole he had bored through the intervening wall. But Mr. Chapman did nothing to stop the rape. Only after it was over, did he burst into the room, declaring "Now I have caught you." "899 Three days later, Mr. Chapman filed a bill for divorce, alleging that his wife had committed adultery with Reagan. ${ }^{90}$ On appeal, Mr. Chapman argued that his actions were too tangential to make him an accomplice: that he had simply remained passive throughout the crime, that his agreement with Reagan had called for seduction, not rape. ${ }^{91}$ The court decisively rejected this claim, applying standard principles from the law of accomplice liability. ${ }^{92}$ It also described what it understood to be the source of Mr. Chapman's "moral guilt." ${ }^{\text {"93 }}$ In doing so, the court did not simply explain that Maggie Chapman had been subjected to unwanted and forced sex. That would hardly have been a sufficient foundation for the case. Mrs. Chapman, remember, would have suffered no legally cognizable injury if the man in bed with her had been her husband. Rather, the opinion stressed that Mrs. Chapman, a married woman, had been subjected to extramarital intercourse, sex the judges took to be illicit and demeaning by definition. Jeremiah Chapman had then compounded his crime by falsely accusing his wife of adultery, subjecting her to the stigma of extramarital intercourse once more. In the court's words:

A husband who could barter with another for the despoiling of his wife's virtue, and stand by to witness it ..., and remain passive and silent while such object was obtained by violence, and then use such permitted and encouraged rape to divorce her from him, and by this, and perjury added, publish her to the world as an

\footnotetext{
89. Id. at 896.

90. See id. at 897.

91. See id. at 896-97.

92. As the court reasoned:
}

The husband was not a mere passive looker-on in the proceedings. Reagan knew he was in the next room, in sight of his work; and when the wife screamed, and respondent did not interfere, he knew that the husband was willing he should succeed in the accomplishment of the intercourse by force, if necessary, - an intercourse which had been bargained for by the husband. And the presence of the husband in the next room, waiting to catch the parties together, known to Reagan, both as to the presence, and the purpose of such presence, imparted to him a confidence in his undertaking. And the husband intentionally gave reason for such confidence. By the lifting of his finger or the opening of his mouth he could have prevented the injury to his wife, but he did not do so.

Id. at 897.

93. Id. at 898 . 
adulteress, is morally guilty of as foul a crime as can be named in the calendar. ${ }^{94}$

State v. Dowell,,$^{95}$ decided four years later in the Supreme Court of North Carolina, also enforced the third-party caveat. In this case, "[t]he white husband of a white wife, under menace of death to both parties in case of refusal, and supporting his threat by a loaded gun held over the parties, [had] constrain[ed] a colored man to undertake, and his wife to submit to, an attempted sexual connection." "96 Without doubt, the racial composition of this crime had overwhelmingly increased the likelihood of prosecution, conviction, and affirmation on appeal; witness how the North Carolina court stated the facts. But in reasoning about the third-party caveat to the marital rape exemption, the court here, like the court in Chapman, explained the rule as illustrating and reinforcing the divide between licit and illicit intercourse so that it turned on whether the woman was married to her sexual partner, rather than on the woman's consent. The fact that Dowell had attempted to force a black man to rape his wife certainly underscored the illicit nature of the intercourse at issue, but did not change the basic framework in which the court understood the problem:

The defendant strangely insists that he is not guilty because he is the husband of the prosecutrix; and he relies as a defense upon the marital relation, the duties and obligations of which he has, by all the laws of God and man, so brutally violated. In our opimion, in respect to this offense, he stands upon the same footing as a stranger, and his guilt is to be determmed in that light alone. . . It is true that [a husband] may enforce sexual connection; and, in the exercise of this marital right, it is held that he cannot be guilty of the offense of rape. But it is too plain for argument that this privilege is a personal one, only. Hence if ... the husband aids and abets another to ravish his wife, he may be convicted as if he were a stranger. The principle is thus tersely expressed by Sir MATTHEW

94. Id. (emphasis added). The dissent in Chapman condemned Jeremiah Chapman's conduct in even harsher terms. See id. at 901 (Sherwood, J., dissenting) ("It is hard to conceive of an act more cruel, or conduct more flagrant and injurious, to the young wife, whose person, pride, and chastity were violated and mangled, and whose hope, happiness, and life have been essentially destroyed, than was perpetrated by the villainous defendant ....") (emphasis added).

It is important to note that the Michigan Supreme Court ultimately set aside Chapman's conviction based on procedural inadequacies in his preliminary examination. See id. at 900-01. This outcome might be taken to mean that the court actually harbored some uneasiness about jailing a husband for a rape committed on his wife. But there was certainly no statement to that effect in the Chapman opinion. Perhaps, as the dissent argued, see id. at 904 (Sherwood, J., dissenting), the procedural irregularity in Chapman-the fact that none of the depositions taken at the preliminary examination were signed, see id. at 900-was too minor to justify setting aside the conviction. But the holding in Chapman did nothing to create particular obstacles to future third-party rape prosecutions against husbands. The procedural issue that was dispositive in Chapman applied to all criminal cases equally.

95. 11 S.E. 525 (N.C. 1890).

96. Id. at 525 . 
HALE: "For, though in marriage she hath given up her body to her husband, she is not to be by him prostituted to another."97

Authoritative legal sources in the nineteenth century agreed that a husband could not, and should not, be prosecuted for raping his wife. Their explanations, grounded in principles and presumptions evident throughout nineteenth-century regulation of the marital relation and sexuality, explicitly assumed and supported the legal subordination of wives to husbands. Judges, lawyers, and legislators may have been willing to oversee some modification of other aspects of women's legal status at common law in the latter half of the nineteenth century, but they remained emphatically unwilling to tamper with a husband's marital rape exemption.

\section{The Marital Rape Exemption's Effect on the Lived Experience of Marriage in the Nineteenth Century}

It is far simpler to discern how the marital rape exemption was explained and defended in judicial opinions and legal treatises than to discover how a husband's conjugal rights affected the lived experience of marriage in the nineteenth century. But the debate over marital rape turned on more than the arguments for the exemption put forth by judges and lawyers. The feminist campaign against marital rape did not simply treat a husband's right to control the terms of marital intercourse as an apt symbol of wonren's legal subjugation. The women challenging that right understood it to have important practical consequences for the shape of women's married lives. Moreover, the popular prescriptive literature that began to delineate the harm of marital rape in the second half of the nineteenth century focused exclusively on actual practice. These marriage manuals and health guides did not seek to change the legal rule granting husbands conjugal riglits, but sought to ameliorate the functional effect of the exemption by convincing husbands to voluntarily cede control of niarital intercourse to their wives.

By defmition, the marital rape exemption meant that women subject to forced sex in marriage did not have the option of seeking criminal prosecution. It is not surprising that I was able to locate no nineteenthcentury prosecutions of a husband for raping his wife. ${ }^{98}$ The existence of the exemption made such attenipts patently futile. The other practical consequences of the exemption are more hidden from view. Feminists and prescriptive writers engaged in a frank and voluminous dialogue about marital intercourse and marital rape in the latter half of the nineteenth century, but the social scientists of their era shied away from the subject. The studies of women's sexual experiences in marriage that do exist,

97. Id. (quoting HALE, supra note 64, at 629) (emphasis added).

98. See supra text accompanying note 54 . 
however, suggest a widespread desire among women to control the terms of marital intercourse, a widespread recognition that they did not have the right to exercise this control, and a widespread experience of harm caused by unwanted sex in inarriage.

Katharine Bement Davis's Factors in the Sex Life of Twenty-Two Hundred Women (1929) ${ }^{99}$ is the most systematic and rigorous examination of women's experience of sex in marriage during this approximate period. ${ }^{100}$ Davis, a social scientist and penologist, ${ }^{101}$ sent ten thousand letters to selected wives, asking thein if they would be willing to answer and anonymously return a questionnaire about their sexual experiences. ${ }^{102} \mathrm{Her}$ questionnaire was very thorough, ${ }^{103}$ and she ultimately received completed answers from 1073 married women. ${ }^{104}$ Davis's study is not ideal for a

99. Katharine Bement Davis, Factors in the Sex Life of Twenty-Two Hundred Women (1929).

100. At least two other studies of the sexual lives of married women were published in the United States in the early twentieth century. Dr. G.V. Hamilton published A Research in Marriage in 1929. This study, which was begun in 1924, reported the results of Hamilton's interviews with one hundred married women and one hundred married men, all volunteers solicited casually through personal contacts. See id. at xi, 1-2. Hamilton, a psychiatrist, asked his subjects a number of questions that might cast light on how the terms of intercourse were negotiated in actual marriages. But he presented the findings of his research in such a condensed form that they are difficult to interpret.

For instance, Hamilton asked his subjects: "Is sex intercourse between you and your (spouse) always a matter of mutual desire, or does your (spouse) at times merely submit to it because you desire it?" "Id. at 159 tbl.102. His report of their answers focused solely on the frequency of submission, without offering any qualitative information. Hamilton's chart reveals that wives often submitted when they did not desire intercourse. Seventy-three of the hundred wives reported having submitted at some point in their marriages, where only three reported that their husbands had ever submitted to them. See $i d$. Sixty-four of the hundred husbands reported that their wives had submitted to them, where only seven reported that they had ever submitted. See id. Hamilton's study does not indicate, however, the terms of this "submission." We do not learn, for example, whether (and why) any of these wives felt an obligation to submit, or feared physical violence if they refused.

Robert Latou Dickinson and Lura Beam published A Thousand Marriages: A Medical Study of Sex Adjustment in 1932. This study was based on the records that a single obstetrician/gynecologist had kept in the course of forty-seven years of practice. See id. at xvi, 3. It focused on the relationship between a woman's gynecological health and her sexual "passion" or "frigidity" in marriage. See id. at 3. The work did not consider the amount of control, or lack thereof, that wives were able to exercise over the terms of marital intercourse.

101. For brief accounts of Davis's career, see Estelle B. Freedman, Their Sisters' KeEpers: Women's Prison Reform IN AMERICA, 1830-1930, at 116-18 (1981); Nicole HaHN Rafter, Partial Justice: WOMEN, Prisons, ANd Soclal Control 60, 65-66, 69-72, 79, 153 (2d ed. 1990).

102. See DAvis, supra note 99, at xi. "From these 10,000 women," Davis reports that she "received requests for the questionnaires from about one third, and about one third of those receiving them filled them out and retumed them." Id.

103. Among other topics, Davis's questionnaires covered: childhood influences, sex education, sexual intercourse before marriage, expectations about marital intercourse, marital happiness, birth control practices, abortion, the frequency of intercourse, female sexual pleasure and orgasm, the relationship between sexual desire and the menstrual cycle, masturbation, and homosexuality. See id. at 1-78, 151-86, 218-37, 297-328.

104. See id. at xi. "For the most part, however," Davis "used only the first 1,000 received, as the additional 73 cases had no important effect on the results." $I d$. at xi-xii. Davis also sent a different questionuaire about sex to 1200 unmarried women. See id. at xiii. 
number of reasons, including its concentration on women somewhat younger than the contemporaries of the first woman's rights movement and its narrow focus on the middle class and the elite. ${ }^{105}$ But notwithstanding its shortcomings, the study offers valuable information about the nature of actual sexual practices in the approximate era in which the first organized woman's rights movement challenged a husband's conjugal rights. Her report presents a fascinating window into women's lives.

The women Davis surveyed repeatedly made clear that they had entered into marriage with the expectation that their husbands had the right to control the terms of marital intercourse, although they were hardly enthusiastic about that husbandly prerogative. When asked whether they had been " "adequately prepared by instruction for the sex side of marriage,", 106 a number of women reported that their mothers had explicitly conveyed this information about the nature of marriage to them. As one wife in this cohort explained, "My mother taught me what to expect. The necessity of yielding to her husband's demands had been a great cross in her own life."'107 Davis's questioning about whether the women had been " "attracted or repelled by the way in which married sex relations came into [their] experience" generated even more revealing responses. Nearly a quarter (223) of the first thousand women to respond "replied 'neither." 108

Of these, 173 said that they "took it as a matter of fact"something that every married woman had to go through with, regardless of her feelings. The other 50 qualified the "neither" with the following adjectives: Amused, 1; astonished, 8; bewildered, 3;

105. The Davis study has at least two major limitations. First, Davis published Factors in 1929 and conducted all of her research within the previous dccade, several decades after a husband's conjugal rights were hotly contested by an organized feminist movement. This limitation is partially overcome, however, by the fact that many of the women included in Davis's survey came to maturity in the latter half of the nineteenth century. At the time of their reply, Davis's marricd women respondents ranged in age from twenty-one to eighty-thrce. See id.at 1 . Second, Davis focused on the middle class and the elite. Davis deliberately did not want to survey a purely representative sample of married women. Half of her ten thousand letters went to the members of an unnamed "large national organization," with the organization's leadership instruetcd to choose five thousand "normal marricd women-that is, women of good standing in the community, with no known physical, mental, or moral handicap, of sufficient intelligence and education to understand and answer in writing a rather exhaustive set of questions as to sex experience." Twenty-five hundred other women "wcre selected from published lists of membership in various clubs belonging to the General Federation of Women's Clubs. The choice of names was purely arbitrary except that it was made from the grcat varieties of types and interests represented in this organization, and with a nationwide distribution." The last "2,500 names were taken from the alumnæ registers of women's colleges and coeducational universities, the ehoice of names being made on a basis of age and geographical distribution." Id. at xi.

106. Id. at 63 .

107. Id. at 67. Another respondent noted that "[her] mother had taught [her] that men were chiefly animals." Id. A third woman, who apparently felt that her mother's warnings had been overstated, reported a similar course of instruction: "II think mother gave me an abnormal idea of men by her own sex attitude. . . I thought most men must be beasts."'Id.

108. Id. at $69,68 \mathrm{tbl} . \mathrm{V}$. 
disappointed, 7; frightened, 8; indifferent, 8; indignant, 1; interested, 5; relieved (that it was no worse), 1; resigned, 3; shocked, 1 ; sorry, 1 ; stunned, 1 ; submissive, $2 .{ }^{109}$

Davis's work also suggests that women's marital happiness in this period importantly turned on how a husband chose to wield his authority over marital intercourse-whether a husband actually exercised his admitted rights or restrained himself voluntarily. Women "attracted" by their first experiences of marital intercourse were significantly more likely to report that their subsequent married life had been happy as well. ${ }^{110}$ In explaining what in their early sexual experiences had appealed to them, these women stressed "[o]ver and over again ... the unselfishness, consideration, and self-control of the husband." 111 In contrast, women who had been "repelled" by their introduction to marital intercourse-a group that included almost one quarter (237) of the first thousand women in the study-emphasized "[j]ust the opposite qualities ... . The wife ignorant, unprepared, shocked at the strength of her husband's passion; the husband unable to realize this, inconsiderate, uncontrolled; a long period of adjustment-and if this fails, unhappmess for both."112

Dr. Clelia Duel Mosher's earlier, if significantly smaller and less systematic, survey of married women's sexual lives accords with Davis's findings. ${ }^{13}$ The Mosher study was notably less rigorous than Davis's work. It consists of unprocessed data about just forty-five married women. ${ }^{114}$ Dr. Mosher, a physician and professor at Stanford University, did not attempt to analyze her findings or to publish her study. ${ }^{115}$ That said,

109. Id. at 69 .

110. Davis reports that 116 women responded that they were unhappy with their married life. She compared this group with 116 "happy" women from her survey, chosen to match the unhappy cohort in age and education. See id. at 67 . Of the unhappy group, $28(24.1 \%)$ had been attracted "'by the manner in which married sex relations came into [their] experience'" and $42(36.2 \%)$ had been repelled. In contrast, $54(46.6 \%)$ women in the happy group reported having been attracted by their initial experiences of marital intercourse and $27(23.3 \%)$ repelled. To phrase these findings another way: Eighty-two women in this sample of 232 reported having been attracted by their initial experiences of marital intercourse. Of these 82 women, $54(65.9 \%)$ reported being happy in their married life. Sixty-nine women in this sample reported having been repelled by their introduction to marital intercourse. Of these 69 women, 42 (60.9\%) women were unhappy in their married life. See id. at 68 \& tbl.V.

111. Id. at 69 .

112. Id. at 68 tbl.V, $69,71$.

113. Clelia Duel Mosher, The Mosher Survey: Sexual Attitudes of 45 Victorian Women (James MaHood \& Kristine Wenburg eds., 1980).

114. See James MaHood, Preface to MosHer, supra note 113, at v, vii ( "[O]ur best estimate is that significant information for a total of only 45 different women has come down to us and appears here."); id. ("The blanks [questionnaires] are consecutively numbered, and the last is No. 51. But Blanks No. 7, 37, 39, and 48 are missing in the original, and practically no information appears on Blanks 16A and 49... Stanford Historian Carl Degler identified Blanks 30 and 33 as from the same woman.").

115. See id. at v-vii; Mosher, supra note 113, at 3 (noting that her study "has given the investigator a priceless knowledge for a practicing physician and teacher," but "[s]ome thought of 
Mosher's work provides useful information about an era somewhat earlier than the period that Davis analyzed. Indeed, Mosher's study, conducted between 1892 and 1920, is the earliest known survey of women's sexual practices in the United States. ${ }^{116}$ Seventy percent of the women that Mosher questioned were born before 1870. Seventeen of the forty-five women were born before the Civil War. ${ }^{117}$

Mosher's subjects repeatedly explained that they wished to limit marital intercourse to those occasions when it was agreed to by wife and husband alike. When asked what they thought "would be an ideal habit" of sex in marriage, these women stressed mutuality again and again. "E]verything to be absolutely mutual," they typically responded. ${ }^{118}$ "When desired by both."119 "No habit at all, but the most sensitive regard of each member of the couple for the personal feeling and desires and health of the other."20 "The marital relation when mutual," they explained, "begets a certain bond of love and sympathy that is certainly peculiar only to those happily mated." 121

At the same time, these women-like Davis's subjects-were well aware that the actual conduct of their sexual lives was ultimately under their husbands' control. Some women happily reported that their husbands had agreed to mutuality. One wife, who had intercourse when it was "as much desired by me as by him," explained that her husband was "an unusually considerate man." 122 Another woman with a "[c]onsiderate husband" noted that he had delayed consummating their marriage for two weeks after the wedding. ${ }^{123}$ Many other women in Mosher's study,

arranging this work for publication ... was prevented by pressure of other routine work"); Carl $N$. Degler, Introduction to MosHer, supra note 113 , at xi, xii-xiv, xvii.

Mosher also never indicated her method for selecting subjects. She appears to have relied on volunteers that she knew personally or professionally, women drawn almost exclusively from the upper middle class. See id. at xii ("No clues are provided as to how the respondents were selected. Presumably they were self-selected .... Many of the Mosher women seem to be [Stanford] faculty wives."); id. at xiii ("Thirty-four of the 45 women attended college or normal school; the education of three is unknown. Since very few women or men attended college in the nineteenth century, these women were clearly not typical of the general population."). Moreover, Mosher varicd her methodology over time, altering the questions she asked, sometimes relying on a written questionnaire and sometimes asking her questions orally and recording the answers herself. See MaHood, supra note 114 , at vi-vii; Degler, supra note 115, at xii. Even at their most complete, Mosher's questionnaires never approximated the scope of Davis's inqniry.

116. See MaHood, supra note 114 , at v-vi; Degler, supra note 115 , at xi.

117. See Degler, supra note 115 , at $\mathrm{xi}$.

118. MosHER, supra note 113 , at 114 (Blank No. 10).

119. Id. at 435 (Blank No. 44).

120. Id. at 139 (Blank No. 12).

121. Id. at 276-77 (Blank No. 24); see also id. at 210 (Blank No. 18) ("ITJhe ideal must be a compromise between two and must be the best for both."); id. at 317 (Blank No. 28) ("Special occasion each time. Man should court wife each time.").

122. Id. at 25 (Blank No. 2(a)).

123. Id. at 426 (Blank No. 43); see also id. at 162-63 (Blank No. 14) (reporting that her "ideal habit" was "[sluch as I have-Where intercourse is only held when mutually desired"). 
however, indicated that they were routinely obliged to submit to unwanted sex. These women, like their peers, would have closen to limit marital intercourse to those times "[w]hen both had desire" 124 or "[w]hen acceptable to both." ${ }^{125}$ But they simultaneously reported their husbands" systematic deviation from this ideal and the harm they had experienced as a result. One of these respondents described "having intercourse on an average of once a week," although sexual relations were "[v]ery painful" for her because of injuries sustained in pregnancy and childbirth. ${ }^{126} \mathrm{An}-$ other explained that she had engaged in marital intercourse when she "often felt averse to it" and indicated that her husband controlled decisions about reproduction, the conception of her first child having taken place at "a time chosen by [her] husband as one that would probably result in pregnancy though [she] did not know his thought at the time."127 Some reported deep disappointment and dissatisfaction in marriage. One woman had repeatedly been subject to much more frequent intercourse than she desired. ${ }^{128}$ Although she felt "[in]ore alive mentally \& physically" after sexual climax, she concluded nonetheless that her sexual experience in marriage had been "[n]ot agreeable" and that "men ha[d] not been properly trained." 129 A second woman in the saine position wrote, more emphatically, of the "[s]hock and destruction of all ideals: When a pure woman is treated by her husband as he has treated the prostitute he has been to before marriage, it becomes loathsome."130

Although tantalizingly incomplete, Davis's study and Mosher's work provide some insight into how women negotiated marriage in the law's shadow. The responses to these surveys reflect a definite understanding that men had the authority to determine the conditions of marital intercourse and women the obligation to submit to whatever sexual demands their husbands chose to make. This understanding surely reflected social norms about acceptable marital behavior. But it would be a mistake to conclude that the popular expectations that Davis and Mosher reported were not linked to the law's embrace of the marital rape exemption. The married women who responded to the questionnaires that Davis and Mosher distributed made clear that unwanted sex in marriage had caused them real harm and that they would have greatly preferred it if their husbands had respected their desires about sexual intercourse. Yet they knew

124. Id. at 423 (Blank No. 42).

125. Id. at 409 (Blank No. 40).

126. Id. at 44 (Blank No. 3).

127. Id. at 252 (Blank No. 22).

128. See id. at 407 (Blank No. 40).

129. Id. at 408 (Blank No. 40); see also id. at 9-11 (Blank No. 1) (reporting more frequent marital intereourse than desired, although she "[c]onsidered that [marital intercourse] sh'd be regulated largely by the woman").

130. Id. at 421-23 (Blank No. 42). 
that their husbands had a right to act differently, to diverge from what these women took to be the most desirable standard of marital conduct. This understanding about a husband's right to marital intercourse may have had nonlegal sources. But it was certainly given enormous strength and realism by the fact that the criminal law categorically refused to entertain claims based on forced sex in marriage, especially when combined with the legal and socioeconomic obstacles to securing a divorce based on marital rape (which will be discussed below). ${ }^{131}$ As a practical matter, the marital rape exemption limited a woman's options if she sought to avoid marital rape. As a normative matter, the exemption added the law's sanction to husbandly claims of marital authority. The marital rape exemption was not just a theoretical question for the law books and the legal treatises. It affected how women lived their married lives.

Yet this is hardly the full story of the marital rape exemption in the nineteenth century. Authoritative legal sources unambiguously endorsed the exemption, and the popular understanding of a man's marital rights seems to have tracked the legal rule. This does not mean, however, that a husband's conjugal prerogatives went uncontested in the nineteenth century. As Part II recounts, the nineteenth-century woman's rights movement fought against a husband's right to control marital intercourse in a campaign that was remarkably developed, prolific, and insistent, given nineteenth-century taboos against the public mention of sex or sexuality. Leading feminists identified a husband's conjugal rights as the crucial constitutive element of women's subordination. They called for both an enforceable right to refuse a husband's sexual demands and realistic socioeconomic alternatives to submission. The record of this struggle dramatically expands our understanding of the history of marital rape, and also provides important new insights into the goals, progress, and efficacy of the first organized woman's rights movement, which historians now frequently describe as overwhelmingly dominated by the battle for suffrage.

At the level of prescriptive norms about marital behavior, discussed in Part II, the organized feminist critique had genuine resonance, but ultimately not transformative power. The advocates of "free love," who operated on the leftward fringe of organized feminism in the nineteenth century, articulated the arguments of the woman's rights movement in a more radical voice. More surprisingly, popular tracts on marriage, reproduction, and health agreed that the exemption's consequences should be curbed in actual practice. Very soon after the organized woman's rights movement mobilized against a husband's conjugal rights, these mainstream authors began to describe and denounce the harm that marital rape inflicted on wives. This prescriptive literature, though, did not contest a

131. See infra Parts II.B, III.A, IV. 
husband's legal right to determine the terms of marital intercourse. Instead, it called on husbands to voluntarily refrain from exercising their legal prerogatives, on the ground that such restraint would benefit them as much as their wives. Where feminists demanded a structure of rights to free women from subordination in marriage, the prescriptive literature turned the concern over marital rape into a call for voluntary strategies to enhance marital happiness and harmony, to be pursued to the extent that they served a husband's interests.

In the end, as Part IV explains, the nineteenth-century femimists lived to see no legal reform of a husband's conjugal prerogatives beyond marginal adjustınents in the terms on which divorce was available. The marital rape exemption outlasted the rise of the first organized woman's rights movement in the United States, the enactment of the first married woinen's property acts, and the ratification of woman suffrage, but not because the issue was uncontroversial or unspeakable. In this realm where sex and reproduction were so clearly at issue, authoritative legal sources, like mainstream prescriptive authors, were unwilling to translate the growing social recognition that marital rape inflicted severe harm on wives into a legal acknowledgment of the dangers potentially posed by the marital relation, through the granting of legal rights that women might enforce against their husbands.

III

\section{The First Organized Feminist Campaign Against a Husband's Conjugal Rights}

Almost immediately after the Seneca Falls Convention in 1848 sparked the formation of the first organized woman's rights movement in the United States, ${ }^{132}$ feminists began to argue that full political and economic rights, including even the vote, would not be nearly sufficient to establish women's equality with men. Although the woman's rights movement was committed to each of these reforms, feminists simultaneously contended that all of them would ultimately prove hollow unless a married woman also had the right to regulate her husband's sexual access-the right to her own person, in the language of the mineteenth century. Nineteenth-century Americans were reluctant to speak openly about

132. For a full account of the Seneca Falls Convention, see History OF WOMAN SuFrRage, supra note 10, at 67-73. This convention adopted a "Declaration of Sentiments" that demanded the reform of coverture laws. See Declaration of Sentiments (1848), reprinted in HiSTORY OF WOMAN SUFFRAGE, supra note 10, at 70, 70 ("[Man] has made [woman], if married, in the eye of the law, civilly dead.... [A married woman] is compelled to promise obedience to her husband, he becoming, to all intents and purposes, her master-the law giving him power to deprive her of her liberty, and to administer chastisement."). A woman's right to her person, however, was not mentioned. See id. at 7071. 
$\operatorname{sex},{ }^{133}$ and the leaders of organized feminism were well aware of the social sanctions for sexual frankness. But their commitment to establishing a woman's right of self-possession as the foundation of her equality led feminists to offer a systematic and thorough critique of marital rape in language wholly understandable to contemporary audiences.

The consensual account of the history of niarital rape now accepted by the exemption's supporters and critics alike is simply wrong as a factual matter. The nineteenth-century woman's rights movement contestcd a husband's right to determine the terms of marital intercourse vociferously and profoundly. Indeed, this campaign constitutes an important chapter in the history of organized feminism in the nineteenth century, one that sheds new light on the nature and dimensions of that movement.

Many historians have described the leadership of the nineteenthcentury woman's rights movement as classically liberal, meaning intent on securing a gender-neutral distribution of political and economic rights and uninterested in transforming the structure of familial relations. ${ }^{134} \mathrm{On}$ this account, the first organized feminist movement sought to apply the principles of the Declaration of Independence to women, without challenging any of the document's other premises. Specifically, these historians contend that feminists grounded their appeal for gender-neutral rights of access to the public sphere in a natural rights argument that stressed "that women were essentially human and only incidentally female" 135 and regarded any mention of women's particular position, especially in the family, "as suspect."

133. As late as 1899 , the frank discussion of sexual intercourse could be controversial at official gatherings of medical professionals. That year, Dr. Denslow Lewis presented a paper on the "Gynecologic Consideration of the Sexual Act" at a meeting of the American Medical Association (AMA). Denslow Lewis, The Gynecologic Consideration of the Sexual Act 23, 5-19 (M \& S Press 1970) (1900). One of his colleagues objected to the presentation, on the ground that the discussion of sex was "attended with more or less filth and we besmirch ourselves by discussing it in public." Id. at 20. The AMA declined to publish Lewis's work. See id. at 23-49. The AMA was a socially conservative organization, but its members' concerns were hardly unusual in this respect. Even progressive figures committed to the cause of sex education frequently expressed deep discomfort about breaching social proprieties. "Which shall we prefer," one such troubled writer asked in 1866 ,

an eruption of all the secrets of the physician into print and wood-cuts, every counter strewn with them, and boys and girls invited to premature fancies-or the old ignorance of sacred laws of the sexual relation, the old subjection of woman to the slavery of superfluous childbearing, with all the disgust, alienation, hidden chagrin, foundered health and spirits, which that brings?

J.W., Book Notice, Radical (Boston), Aug. 1866, at 492, 492 (reviewing R.T. Trall, Sexual PHysiology (1866)). John Weiss recommended "telling the truth with greater economy of details." Id.

134. By employing the term "classically liberal," I mean only to denote the sct of ideas stated above. My use of the designation is not intended to endorse any broader claims about the nature of classical liberalism, a much disputed subject.

135. DuBois, supra note 22 , at 36 .

136. DuBois, supra note 13, at 846 . Aileen Kraditor similarly explains the position of the organized woman's rights movement: 
appropriate way to recognize their equality was by distributing political liberty, namely the right to vote for democratically elected representatives. ${ }^{137}$ This historical interpretation of the woman's rights novement is grounded in a reading of women's demands for suffrage. But historians have extrapolated from the debate over suffrage to conclude that the nineteenth-century feminist movement was neither alert to sources of inequality within the family that affected women's power and resources as a class nor committed to gender-specific structural reform. ${ }^{138}$ Even where these historians briefly allude to the femimist claim for self-ownership in marriage, they do not indicate that this discussion might challenge their understanding of the movement. ${ }^{139}$ Nineteenth-century femimists certainly did rely on arguments grounded in classic liberalism, which was the dominant philosophical tradition of the era and well suited to the suffrage demand. Indeed, the Declaration of Sentiments adopted at Seneca Falls

If all men were created equal and had the inalienable right to consent to the laws by which they were governed, women were created equal to men and had the same inalienable right to political liberty. In asserting that natural right applied also to women, the suffragists stressed the ways in which men and women were identical. Their common humanity was the core of the suffragist argument.

Aileen S. Kraditor, The Ideas of the Woman Suffrage Movement, 1890-1920, at 44 (1965); see also Keith E. Melder, Beginnings of Sisterhood: The American Woman's Rights Movement, 1800-1850, at 154 (1977) ("All humans are equal in the sight of God and nature, was the assumption [of the nineteenth-century woman's rights movement], equal not necessarily in talents or endowments, but in basic rights and responsibilities. Aileen Kraditor has identified this approach as the argument for justice, eternal and undifferentiated, not dependent on gender.").

137. As Anne Firor Scott and Andrew MacKay Scott have observed:

Though the demand that women should be permitted to vote was radical in its implications, the argument was familiar. People who could not vote were being governed without their consent. The Declaration of Sentiments asked only that the Declaration of Independence be followed to its logical conclusion. If rights were given by the Creator was it likely that he discriminated on grounds of sex? Women were one-half the population. If they had no right to vote, the idea of consent of the governed was hollow.

Anne Firor Scott \& Andrew Mackay Scott, One Half the People: The Fight for Woman Suffrage 9-10 (Univ. of Illinois Press 1982) (1975); see also DuBois, supra note 13, at 841 ("The demand for political equality could inspire a women's rights movement among women from 1848 on because political democracy was simultaneously a widely held belief and a radical assertion when applied to women. Political equality for women rested on the popular republican tradition that insisted on equal rights for all, with the franchise the crowning jewel of individual freedom.").

138. See DuBols, supra note 22, at 37 (arguing that organized feminist movement, focused on establishing "that men and women were morally identical," "ignored the reality of women's domestic confinement, which made them different from and dependent on men"); Elizabeth B. Clark, Matrimonial Bonds: Slavery and Divorce in Nineteenth-Century America, 8 LAw \& HIST. REV. 25, 49 (1990) [hereinafter Clark, Matrimonial Bonds] ("Stanton's preoccupation with individual freedom prevented her from developing a coherent class-based theory that invoked systematic legal or institutional remedies to women's position in marriage."); Elizabeth B. Clark, Self-Ownership and the Political Theory of Elizabeth Cady Stanton, 21 CONN. L. REv. 905, 934 (1989) ("Elizabeth Cady Stanton's extreme individualist orientation made it very difficult for her at any stage in her career to develop a substantive theory of the state, or a theory of class action within the state.").

139. See DuBois, supra note 13 , at $843,856-57$. 
was explicitly modeled on the Declaration of Independence. ${ }^{140}$ Yet, as the feminist argument for a wife's right to control her own person makes clear, the notion that the woman's rights movement limited itself to applying established liberal principles to women vastly understates the scope of the movement's theoretical commitments. These feminists began with liberalism's dedication to freedom and autonomy, but took it in radically new directions.

In defining what the right to one's own person meant, articulate feminists did not focus on gender-neutral rights to the public sphere or freedom from coercion by the state. They were concerned about married women who submitted to their husbands' sexual demands as the result of force, or threats, or because they lacked palatable alternatives. The woinan's rights movement sought to establish a wife's right of refusal and to renıake women's social and economic possibilities to create realistic alternatives to marriage. In making these claims, feminists recognized that some of the most important barriers to female self-possession were located within the structure of marriage, as well as the behavior of individual husbands. Feminists criticized both a husband's legal right of sexual access and the coverture rules that stripped married women of control over their family's resources. They also objected to the tenuous circumstances under which many never-married, separated, and divorced women lived, subject to both explicit exployment discrimination that left woinen with few ways to support themselves outside of narriage and the social stigma associated with living outside a husband's household. ${ }^{141}$ Indeed, feminists called unwanted marital intercourse, where the wife had acquiesced because of lier economic and social dependence on her husband, legalized prostitution..$^{142}$ By that, they meant that the wife who was structurally compelled to have sex when she did not desire the act or its reproductive consequences was different only in naine from the woinan without any available option but to sell her body to strange men on the

140. See History of Woman SufFrage, supra note 10, at 68 ("After much delay, one of the [women gathered to write the Declaration of Sentiments] took up the Declaration of 1776, and read it aloud with much spirit and emphasis, and it was at once decided to adopt the historic document, with some slight changes such as substituting 'all men' for 'King George.'”); Declaration of Sentiments, supra note 132, at 70 ("We hold these truths to be self-evident: that all men and women are created equal ....").

141. As the Declaration of Sentiments adopted at the Seneca Falls Convention elaboratcd:

[Man] has monopolized nearly all the profitable employments, and from those she is permitted to follow, she receives but a scanty remuneration. He closes against her all the avenues to wealth and distinction which he considers most honorable to himself. As a tcacher of theology, medicine, or law, she is not known.

He has denied her the facilities for obtaining a thorough education, all colleges being closed against her.

Declaration of Sentiments, supra note 132, at 71.

142. This casts doubt on Elizabeth Clark's argument that the organized woman's rights movement felt "compelled to downgrade the importance of financial 'security' in marriage, in order to establish it as an affective relationship between equals." Clark, Matrimonial Bonds, supra note 138, at 49. 
street. In this vision, women's economic, legal, and bodily vulnerabilities in marriage were all intricately connected. In demanding a woman's right to her own person, feminists fought all of these inequalities simultaneously.

This claim, moreover, was intensely gender-specific. Feminists campaigning against marital rape focused solely on a woman's right to control marital intercourse, and they did not articulate their demand as a call for women to receive the same protections that men enjoyed. Their argument for self-ownership was not based on a theory of bodily inviolateness that would apply to man and woman like. Rather, it looked to women's exclusive responsibility for raising children. Nineteenth-century feminists did not celebrate the norm assigning women all of the work of childcare. Nonetheless, they took it to be such a profound social expectation that they reasoned within it, contending that women needed to have control over marital intercourse so that they could regulate the amount of their lives they devoted to motherhood. In demanding a woman's right to her own person, the nineteenth-century feminist movement was asserting an equal right, and challenging gender-based subordination, in a completely gender-specific way. This is not to suggest that the woman's rights movement would have countenanced sexual violence against men. But organized feminism explained the right to self-ownership in an idiom radically different from that employed by the nation's founders, one that was grounded in a gender-specific understanding of the comparative social position of women and men.

\section{A. A Wife's Right to Her Person as the Predicate for Women's Equality}

The feminist critique of women's legal subordination quickly focused on a married woman's lack of control over her own person. This concern, moreover, was evident throughout the woman's rights movement; feminists' substantive views on the issue differed far less than their strategic appraisals about how it could best be pursued. The most useful starting point for understanding what organized feminism took to be at stake in demanding a wife's right to her person lies in the work of Elizabeth Cady Stanton, the most prominent and brilliant theorist of the movement.

As early as 1852 , Stanton argued that marital intercourse was inappropriate under certain conditions. Addressing a temperance convention, she warned of the dire eugenic consequences of having children with an alcoholic husband and informed the wives of such men that they should cease sexual relations at once. "[L]ive with him as a friend," Stanton advised, "watch over and pray for him as a mother would for an erring son, soothe him in his wretchedness, comfort and support him, as best [you] may_but for woman's sake, for humanity's sake, be not his wife-bring 
no children to that blighted, dreary, desolate hearth."143 This exhortation, of course, left the key question ambiguous: How exactly was a wife to carry out her responsibility when her husband insisted on sexual access? Did Stanton expect a wife to rely solely on moral suasion? If so, what if persuasion did not work? ${ }^{144}$ Indeed, one might read this statement as placing married women in a double bind, wherein they would be held morally responsible for reproduction that they did not, in fact or in law, have the ability to control. Stanton's early ambiguity was deliberate. As she explained in a letter to Susan B. Anthony, her closest ally, Stanton had grave doubts about "whether the world [was] quite willing or ready to discuss the question of marriage." 145 But Stanton's commitment to securing a married woman's right to her own person was clear. Indeed, in the same letter, she identified the issue as the pivotal site of women's subordination:

It is in vain to look for the elevation of woman so long as she is degraded in marriage.... Man in his lust has regulated long enough this whole question of sexual intercourse. Now let the mother of mankind, whose prerogative it is to set bounds to his indulgence, rouse up and give this whole matter a thorough, fearless examination.... I feel, as never before, that this whole question of woman's rights turns on the pivot of the marriage relation, and, mark my word, sooner or later it will be the topic for discussion. I would not hurry it on, nor would I avoid it. ${ }^{146}$

In 1855, Stanton found the appropriate occasion for public frankness. ${ }^{147}$ That year, her cousin, Gerrit Smith, a leading antislavery reformer who was sympathetic to feminism, wrote her a public letter about the

143. Elizabeth Cady Stanton, Mrs. Stanton's Address, L1LY (Seneca Falls, N.Y.), May 1852, at 39, 41 (speaking at the second Women's Temperance Convention of the State of New York, April 20 , 1852).

144. Antoinette Brown Blackwell made a similarly ambiguous statement at the Tenth National Woman's Rights Convention, held in New York on May 10 and 11, 1860. See Tenth National Woman's Rights Convention, in HistoRY OF WOMAN SuFfrage, supra note 10, at 688, 727 ("'[Is a woman bound, because] legally married to one who is debased to the level of the brute, to be the mother of his children?' ... 'No! . . you are bound never to make one whom you do not honor and respect, as well as love, the father of any child of yours."') (statement of Antoinette Brown Blackwell).

145. Letter from Elizabeth Cady Stanton to Susan B. Anthony (Mar. 1, 1853), in 2 ElizaBETH Cady Stanton: As Revealed in Her Letters, Diary and Reminiscences 48, 48 (Theodore Stanton \& Harriot Stanton Blatch eds., 1922).

146. Id. at 48-49.

147. Stanton had already briefly alluded to the issue in an address prepared for the New York Legislature that she also presented at a woman's rights convention held in Albany in 1854. See Mrs. Stanton's Address, Albany Convention, in HistoRY OF WoMAN SuFFraGE, supra note 10, at 591, 599 ("[T] he signing of this [marriage] contract is instant civil death to one of the parties. ... [The wife] can own nothing, sell nothing. She has no right even to the wages she earns; her person, her time, her services are the property of another.") (emphasis added); id. at 605 ("Think you the wife of the confirmed, beastly drunkard would consent to share with him her home and bed, if law and public sentiment would release her from such gross companionship? Verily, no!") (cmphasis added). 
woman's rights movement. ${ }^{148}$ In this letter, he argued that women's continued inequality was largely the result of their dress, which was admittedly constraining and impractical. ${ }^{149}$ Stanton, in a forceful and public reply, explained women's inequality as rooted in their lack of control over their person. ${ }^{150}$ She identified this right as the most important that women hoped to achieve, more significant than any of the rights for which women had been publicly agitating simce 1848 . Indeed, Stanton articulated a view

148. Smith and Stanton had been discussing woman's rights for at least two years, in private correspondence that mirrored their eventual public writing. Smith, for instance, wrote Stanton at the end of 1853 to clarify his position. By that point, the general outlines of their dispute were already distinct. Smith explained:

My wife says that you do not regard me as going far enough. I believe no one can go further than $1 \mathrm{do}$. She says that you claim for every wife the right to her person against the tyranny and lust of her husband. So do I. But so long as she is dependent and poor, she will fail to establish this right; and so long as she remains in her clothes-prison, she will be dependent and poor. I believe you can make no claim for woman to which I do not respond. Do not regard me as opposing or ignoring any such claim. If we differ at all, it is only that you do not regard a radical change in the dress of woman to be indispensable to the achievement of the rights and independence of woman. But I hope we do not differ on this point.

Letter from Gerrit Smith to Elizabeth Cady Stanton (Dec. 19, 1853) (on file with author; Elizabeth Cady Stanton Papers, Library of Congress). As this missive implies, Stanton was never convinced of the need to prioritize dress reform above all else. In a letter to Smith from the early $1850 \mathrm{~s}$, she presented a different agenda:

Our laws, our customs, our fashions, are founded in some philosophy - All those relating to woman in the false one that God made woman for man - to grace his home, to minister to his necessities, to gratify his lust, hence our laws make her a mere dependent, she has no rights to houses or lands, to silver or gold, not even to the wages she earns. She is given in marriage like an article of merchandize.... [And] she that is given never dreams that she herself has the most sacred right to her own person.... The rights of humanity are more grossly betrayed at the altar than at the auction block of the slave-holder ....

Letter from Elizabeth Cady Stanton to Gerrit Smith 1-3 (Jan. 5, 1851?) (on file with author; Elizabeth Cady Stanton Papers, Library of Congress).

149. Smith's argument proceeded along the following limes:

I admit that the dress of woman is not the primal cause of her helplessness and degradation. That cause is to be found in the false doctrines and sentiments of which the dress is the outgrowth and symbol. On the other hand, however, these doctrines and sentiments would never have become the huge bundle they now are, and they would probably have all languished, and perhaps all expired, but for the dress. ... .

Were woman to throw off the dress, which, in the eye of chivalry and gallantry, is so well adapted to womanly gracefulness and womanly helplessness, and to put on a dress that would leave her frec to work her own way through the world, I see not but that chivalry and gallantry would nearly or quite die out. No longer would she present herself to man, now in the bewitching character of a plaything, a doll, an idol, and now in the degraded character of his servant. But he would confess her transmutation into his equal; and, therefore, all occasion for the display of chivalry and gallantry toward her on the one hand, and tyranny on the other, would have passed away.

Letter from Gerrit Smith to Elizabeth Cady Stanton (Dec. 1, 1855), reprinted in HISTORY OF WOMAN SUFFRAGE, supra note 10 , at $836,837$.

150. Frances D. Gage, another leading figure in the woman's rights movement, also publicly responded to Smith's letter. She, too, identified a woman's right to herself as the bedrock principle on which equal citizenship depended, although Gage defined this right broadly to include a woman's control over both marital intercourse and her own labor. See Letter from Frances D. Gage to Frederick Douglass' newspaper (Dec. 24, 1855), reprinted in HistoRY OF WOMAN SufFRAGE, supra note 10, at 842, 843 ("We must own ourselves under the law first, own our bodies, our earnings, our genius, and our consciences; then we will turn to the lesser matter of what shall be the garniture of the body."). 
of woman's citizenship that began, locationally, with the body. She understood a woman's right to control her person as the foundational right upon which political and economic equality needed to rest if they were to have any value. Yet when Stanton considered what was at stake in having control over one's person, she did not speak in terms of physical transgression, condemning the bodily invasion of unwanted intercourse or unwanted gestation. Instead, she focused on the social work of reproduction, the work of raising children. Stanton recognized that this work fell exclusively to women, and her demand for self-possession spoke only to women's claims. Stanton's argument about the right of self-ownership was, more accurately, an intensely gender-specific argument about a woman's particular right. She contended that women needed to have full control over marital intercourse so that they could determine how many children they would raise and when. As Stanton explained:

The rights, to vote, to hold property, to speak in public, are allimportant; but there are great social rights, before which all others sink into utter insignificance. The cause of woman is .... not a question of meats and drinks, of money and lands, but of human rights-the sacred right of a woman to her own person, to all her God-given powers of body and soul. Did it ever enter into the mind of man that woman too had an inalienable right to life, liberty, and the pursuit of her individual happiness? Did he ever take in the idea that to the mother of the race, and to her alone, belonged the right to say when a new being should be brought into the world? Has he, in the gratification of his blind passions, ever paused to think whether it was with joy and gladness that she gave up ten or twenty years of the heyday of her existence to all the cares and sufferings of excessive maternity? Our present laws, our religious teachings, our social customs on the whole question of marriage and divorce, are most degrading to woman .... Here, in my opinion, is the starting-point; here is the battleground where our independence must be fought and won. ${ }^{151}$

This was a claim about the right of every woman to control her own person. Moreover, Stanton was certain that the vast majority of women, including those who would never speak publicly, regarded present

151. Letter from Elizabeth Cady Stanton to Gerrit Smith (Dec. 21, 1855), reprinted in HisToRY of WOMAN SUFFaGE, supra note 10, at 839, 840-41. Stanton's 1852 address at the second Women's Temperance Convention of the State of New York also expressed deep dissatisfaction with the fact that most women's lives were devoted wholly to raising children and performing domestic work. She argued that:

[If] one half our race must forever hold a subordinate position, subject to the will and dictation of another, thinking no great thoughts, and feeling no true liberty, always confined to the narrow treadmill round of domestic life, wholly occupicd with trifling matters and ministering to the animal necessities, and lusts of the flesh alone, that part belongs not to woman.

Stanton, supra note 143 , at 40. 
arrangements with "deep and settled disgust."152 At the same time, it is clear that when Stanton thought about the sacrifice involved in a life unwillingly devoted to "excessive maternity," she was particularly mindful of the position of educated and middle-class women, women very much like herself. These women had the wherewithal and the desire to participate in public political life, but not the opportunity, in part because of the temporal demands of child rearing. Elsewhere in her letter to Smith, Stanton described women's frustration-and suggested the role she envisioned for women $\mathrm{m}$ the political community-this way:

[S]uppose yourself a woman. You are educated up to that point where one feels a deep interest in the welfare of her country, and in all the great questions of the day, in both Church and State; yet you have no voice in either. Little men, with little brains, may pour forth their little sentimients by the hour, in the forum and the sacred desk, but public sentiment and the religion of our day teach us that silence is most becoming in woman. ${ }^{153}$

Stanton's argument for a woman's right to her person, first fully developed in public in 1855 , remained her pressing concern for years. ${ }^{154}$ She consistently pursued the issue, with more or less explicitness, although she was well aware that a demand to restructure the most intimate relations of marriage would be extremely controversial. A year after Stanton's reply to Smith, Lucy Stone, another leader of the woman's rights movement, wrote Stanton privately, asking her to speak out again on "a wife's right to her own body" at an upcoming National Woman's Rights Convention, notwithstanding "the censure which a discussion of this question [would] bring." ${ }^{155}$ Stanton agreed to write to the convention, although her public letter was less direct than Stone's private correspondence. Rather than offer a complete account of the claim for control over one's person, Stanton effectively referenced and invoked her earlier argument. "Is it any wonder," she asked, "that woman regards herself as a mere machine, a tool for men's pleasure? Verily is she a hopeless victim of his morbidly developed passions." In the feminist reordering, woman would be "the rightful lawgiver in all our most sacred relations." "156 Women reading this letter would have had no difficulty understanding its intent. In the years to follow, Stanton spoke about a married woman's

152. Letter from Elizabeth Cady Stanton to Gerrit Smith, supra note 151, at 840.

153. Id.

154. For more discussion of Stanton's understanding of a woman's right to herself, see infra text accompanying notes 194-202.

155. Letter from Lucy Stone to Elizabeth Cady Stanton (Oct. 22, 1856), in Elizabetr Cady Stanton, supra note 145 , at 67,68 .

156. Letter from Elizabeth Cady Stanton to Lucy Stone and the National Woman's Rights Convention, Cooper Institute, 1856 (Nov. 24, 1856), reprinted in HISTORY OF WOMAN SUFFRAGE, supra note 10 , at $860,860-61$. 
right "to her person" again and again. ${ }^{157}$ She remained convinced that a wife's right to refuse her husband's sexual demands was the bedrock foundation needed to support equality. "Woman's degradation is in man's idea of his sexual rights," Stanton wrote to Anthony. "How this marriage question grows on me. It lies at the very foundation of all progress." 158

Stanton's understanding of a married woman's right to her person was shared throughout the woman's rights movement. Consider Lucy Stone, who was as prominent a feminist leader as Stanton but one generally taken to be more moderate. Stone absolutely agreed with Stanton that a woman's right to herself was the predicate on which equality depended. She differed from Stanton only in her greater reluctance to discuss the right in public, out of fear that outraged audiences would react by rejecting the entire feminist agenda. Yet despite her strategic hesitancy, Stone still publicly advocated a wife's right of self-possession, including, as we will see, ${ }^{159}$ through the famous protest she issued upon her own marriage. ${ }^{160}$ Stone was more wary of the potential costs of public exposure, but at the same time she was also determined to create public impetus for reform.

The tension in Stone's thought between her substantive commitment to establishing a woman's right to herself and her fears that public agitation on the question would be counter-productive was evident as early as

157. See Letter from Elizabeth Cady Stanton to the Editor of the New York Tribune (May 30, 1860), reprinted in HistoRY of WOMAN SuFFrage, supra note 10, at 738, 738-39 ("An unmarried woman can make contracts, sue and be sued, enjoy the rights of property, to her inheritance-to her wages-to her person-to her children .... It is only in marriage that [woman] must demand her rights to person, children, property, wages, life, liberty, and the pursuit of happiness.") (emphasis added); E.C.S., Marriage and Divorce, LiBERATOR (Boston), June 1, 1860, at 88, 88 (same); ADDREss of Elizabeth Cady Stanton, on the Divorce Bill, Before the Judiciary Committee of The New York Senate, in the Assembly Chamber, Feb. 8, 1861, at 3-4 (Albany, Weed, Parsons \& Co. 1861) ("[I come to plead] the justice of an entire revision of your whole code of laws on marriage and divorce. ... 1t is only in marriage, that [woman] must dcmand her rights to person, children, property, wages, life, liberty and the pursuit of happiness.") (emphasis added); The Property Law (note in pamphlet after Stanton's address), in id. at 13 (noting that the married women of New York were denied "tbe control and custody of [their] own persons"); Letter from Elizabeth Cady Stanton to Wendell Phillips and the National Antislavery Standard (Dec. 26, 1865), reprinted in EL1zABETH CADY STANTON, supra note 145, at 109, 110 ("[I]f the two millions of southern black women are not to be secured in their rights of person, property, wages, and children, then their emancipation is but another form of slavery.") (emphasis added); see also For Women Only: Mrs. Elizabeth Cady Stanton Discourses on Marriage and Maternity, Dally Iowa STATE Register (Des Moines, Iowa), July 29, 1871, at 2, 2 ("We must educate our daughters in this order: First-To regard THEIR OWN LIVES AND BoDIEs and the laws which govern them.").

158. Letter from Elizabeth Cady Stanton to Susan B. Anthony (June 14, 1860), in ElizaBeTH Cady Stanton, supra note 145 , at 82,82 .

159. See infra text accompanying notes 167-173.

160. Moreover, she also encouraged other feminists to speak publicly. Recall Stone's 1856 letter to Stanton. See supra text accompanying notes 155-156. The specific purpose of this letter was to urge Stanton, who had "dare[d] to speak" already, to raise her voice again: "I very much wish that a wife's right to her own body should be pushed at our next convention," Stone wrote. "It does seem to ine that you are the one to do it." Letter from Lucy Stone to Elizabeth Cady Stanton, supra note 155, at 68. 
1853. By this point, Stanton had resolved to speak publicly about the right to self-ownership when an agreeable opportunity arose, ${ }^{161}$ although she would not actually do so for another two years. ${ }^{162}$ Stone, however, remained deeply worried that explicit advocacy was premature. She explained her concerns in a letter to Stanton this way:

One who is in total darkness, finds his eyes pained by the sudden admission of bright light-and closes them. So too with many, who are thinking on the Woman question;-broach in their hearing, these thoughts, that we must think, and feel, and their progress is yet so little, that they will be frightened from further investigation. Such at least, has been my fear. I do not care for any damnation, that may come from any quarter, when I am sure that the full time has come. ${ }^{163}$

As this passage mdicates, Stone's anxieties did not reflect any doubts as to the importance of securing a wife's right to her person. She went on to emphasize that she agreed with Stanton, "in all, except it be the time to strike."164 "I know," Stone said, "that the abuse in question is perfectly appalling. ... One noble woman told me how she fled from her husband, to the Shakers, because he gave her no peace either during menstruation, pregnancy, or nursing." 165 Stone's eagerness to reform the marital relation so that wives controlled their husbands' sexual access was so great that even in a letter devoted to warning Stanton about the risk of public exposure, Stone indicated the appeal that public advocacy on the question held for her as well: "Shall we keep silence when such curses are inflicted through woman upon the race?," Stone asked herself as much as Stanton. "There is, I confess, much force in your reasoning upon the subject."166

Within two years, Stone herself had issued, on the occasion of her marriage, a public and widely distributed protest against a husband's legal control over his wife's person. Stone had long refused to marry because she was unwilling to submit to the operation of coverture principles. "It seems to me," she wrote in 1849 , "that no man who deserved the name of $M A N$, when he knows what a mere thing, the law, makes a married woman, would ever insult a woman, by asking her to marry." 167 Henry

161. See supra text accompanying note 146.

162. See supra text accompanying notes 147-153.

163. Letter from Lucy Stone to Elizabeth Cady Stanton (Aug. 14, 1853), in 1 The SELECTED

Papers of Elizabeth Cady Stanton and Susan B. ANThony 223, 224 (Ann D. Gordon ed., 1997).

164. Id.

165. Id.

166. Id.

167. Letter from Lucy Stone to Antoinette Brown Blackwell (Aug. 1849), in FriendS AND Sisters: Letters Between Lucy Stone and ANTOINetTe Blackwell, 1846-93, at 53, 56 (Carol Lasser \& Marlene Deahl Merrill eds., 1987); see also id. ("It is horrid to live without the intimate companionship, and gentle loving influences which are the constant attendant of a true love 
Blackwell, her patient suitor and a reformer in his own right, ultimately convinced her to change her mind by making clear that, in their marriage, he would never enforce marital status law against her ${ }^{168}$ In particular, she would have total freedom to determine the terms of marital intercourse and, accordingly, unrestrained control over the social relations of reproduction. "You shall," Blackwell assured her, "choose when, where \& how often you shall become a mother." ${ }^{169}$ At Blackwell's suggestion, ${ }^{170}$ Stone agreed to make their arrangement public in the form of a protest to be published immediately after their wedding on May 1, 1855. In this document, Stone and Blackwell specifically rejected the theory of consent underlying marital status law, which conclusively presumed agreement from a couple's decision to wed. They declared that their agreement to marry "implie[d] no sanction of, nor promise of voluntary obedience to such of the present laws of marriage, as refuse to recognize the wife as an independent, rational being, while they confer upon the husband an injurious and unnatural superiority." "In In listing the features of coverture that they rejected, Stone and Blackwell cited a husband's right to "custody of the wife's person" first. ${ }^{172}$ This statement was not as explicit as it might have been, and deliberately so, but it was perfectly understandable to a nineteenth-century audience. Indeed, it specifically inspired other feminists to speak publicly about a wife's right to control her husband's sexual access. ${ }^{173}$ Soon after her wedding, Stone reviewed her objections to the legal terms of marriage in language more accessible to modern readers:

marriage ... but nothing is so bad as to be made a thing, as every married woman now is, in the eye of Law.").

168. See Letter from Henry B. Blackwell to Lucy Stone (Dec. 22, 1854), in LoviNG WARriors: Selected Letters of Lucy Stone ANd Henry B. Blackwell, 1853 to 1893, at 108, 108 (Leslie Wheeler ed., 1981) ("The Law by clothing me with unjust powers puts me in the position of the wrongdoer ... . But after all what is the Law? It is nothing, unless appealed to. It is merely ' $\mathrm{a}$ rule of civil action' in case of such appeal. It exists only where it is invoked."). As their protcst specified, Stone and Blackwell agreed to submit any disputes that arose between them to private arbitration rather than the court system. See Henry B. Blackwell \& Lucy Stone, Protest (1855), reprinted in HisTORY OF WOMAN SUFFRAGE, supra note 10, at 260, 261 ("[M]arried partners should provide against the radical injustice of present laws, by every means in their power. ... [W] [here domestic difficulties arise, no appeal should be made to legal tribunals under existing laws, ... all difficulties should be submitted to the equitable adjustment of arbitrators mutually chosen.").

169. Letter from Henry B. Blackwell to Lucy Stone, supra note 168, at 110.

170. See Letter from Henry B. Blackwell to Lucy Stone (Jan. 3, 1855), in LoviNG WARRIORS, supra note 168, at 115, 115-16 ("I want to make a protest distinct and emphatic against the laws. 1 wish, as a husband, to renounce all the privileges which the law confers upon me, which are not strictly mutual .... Help me to draw one up. .. . Surely such a marriage will not degrade you ....").

171. Henry B. Blackwell \& Lucy Stone, Protest, supra note 168, at 261. This protest was originally published in the Worcester Spy and the Liberator. See HistoRY OF Woman Suffrage, supra note 10 , at 261 .

172. Henry B. Blackwell \& Lucy Stone, Protest, supra note 168, at 261.

173. Caroline Dall, for instance, cited this statement from the protest to explain why she could no longer remain silent about a wife's right to self-possession: 
[I] is clear to me, that [the marriage] question underlies, this whole movement and all our little skirmishing for better laws, and the right to vote, will yet be swallowed up, in the real question, viz, has woman, as wife, a right to herself? It is very little to me to have the right to vote, to own property \&c. if I may not keep my body, and its uses, in my absolute right. Not one wife in a thousand can do that now, \& so long as she suffers this bondage, all other rights will not help her to her true position. ${ }^{174}$

Stone, like Stanton, did not view a wife's right to her person as simply one of many important rights to which women were entitled. Like Stanton, she understood this right as the necessary foundation for equal citizenship, without which all other legal reform would prove near worthless.

Stanton and Stone articulated a perspective that was common in the woman's rights movement. Feminists repeatedly singled out a woman's right to control marital intercourse as the core component of equality. ${ }^{175}$ Paulina Wright Davis, president of the 1871 meeting of the National Women's Suffrage Convention, identified a woman's right to her person as the most crucial right that women needed to achieve. She explained:

That the evils, sufferings and disabilities of the women, as well as of men, are social still more than they are political, and that a

The protest signed by Lucy Stone and Henry Blackwell on the occasion of their marriage, seemed to relate to whatever was most objectionable in all law, every where. I take it, thereforc, section by section, as the foundation of whatever remarks I may wish to make....

$\ldots$

1. The custody of the wife's person.

... Probably no right with which he is invested occasions more suffering than this, yet it is necessarily of a kind to be passed over in silence, and which,- speak of it impersonally as we will,-it seems unfit to press publicly upon the attention of an audience. But, if the results of this right are sustained by the laws of the land; should they be such as we must blush to speak of; if women die under its inflictions, - arc they never to find those of their own sex strong enough to show the reasons why, and pure enough to remain unsuspected in doing so?... In relation to such a right, it may be said, that every thing will depend upon the character of the husband, and that no good man would feel himself justified by it. Precisely for this reason ought the law to be altered. Only the conduct of a violent, abusive man, regardless of all holy obligations, is likely to come before a Court under it; and such men ought not to be sustained by the law ....

Caroline H. Dall, Report Concerning Some of the Laws of Massachusetts in Rclation to Women (July 2, 1855), in Reports on the Laws of New England, Presented to the New England Meeting, Convened SePt. 19 and 20, 1855, at 1, 2 (Boston? 1855).

174. Letter from Lucy Stone to Antoinette Brown Blackwell (July 11, 1855), in Friends AND SISTERS, supra note 167, at 143, 144.

175. Susan B. Anthony, for instance, was convinced that "nearly all the wrongs of which we complain grow out of the inequality, the injustice of the marriage laws, that rob the wife of the right to herself and her children-that make her the slave of the man she marries." In marriage, Anthony concluded, "tyrant law and lust reign supreme." Tenth National Woman's Rights Convention, supra note 144, at 735 (statement of Susan B. Anthony); see also Clarina I. Howard Nichols, Reminiscences, in HISTORY OF WOMAN SUFFrage, supra note 10, at 171, 194, 197 (recounting an 1858 speech in which she discussed "the no-right of the white wife and mother to herself" and the systematic sexual exploitation of slave women by white men). 
statement of woman's rights, which ignores the right of selfownership as the first of all rights, is insufficient to meet the demand, and is ceasing to enlist the enthusiasm and even the common interest of the most intelligent portion of the community. ${ }^{176}$

There is no subject, Matilda E.J. Gage agreed, "which lies deeper down into woman's wrongs" than "the denial of the right to herself." 177 A woman should, Lucinda B. Chandler concurred, "legally hold the custody and control of her person in wifehood to govern according to her wisdom and instincts the maternal office."178 "The repeal of the law of coverture, leaving the wife free to maintain her self-respect and to determine the exercise of her function of maternity, will confer the greatest service legislation can render."179

Giving woman the right "to decide when she shall become a mother, how often \& under what circumstances" was only just, ${ }^{180}$ these arguments continued, because women performed the social work of reproduction. Like Stanton and Stone, these nineteenth-century feminists used women's exclusive responsibility for child rearing to insist that women were entitled to control the terms of this work and determine how much of their lives they would have to spend raising children. ${ }^{181}$ Chandler noted that

176. National Women's Suffrage Convention, Woodhull \& Clafl,IN's WeEKLY (New York, N.Y.), May 27, 1871, at 3, 3.

177. Matilda E.J. Gage, Is Woman Her Own?, Revolution (New York, N.Y.), Apr. 9, 1868, at 215, 215; see also id. ("[N]owhere has the marital union of the sexes been one in which woman has had control over her own body."); Matilda Joslyn Gage, Our Book Table, NaT'L Cirizen \& Ballor Box (Syracuse, N.Y.), Nov. 1878, at 2, 2 ("The law of motherhood should be entirely under woman's control, but in order to be that, woman must first of all be held as having a right to herself.").

178. Lucinda B. Chandler, Woman's Sphere of Motherhood, WomaN's J. (Boston, Chicago, \& St. Louis), Sept. 13, 1873, at 291, 291.

179. Lucinda B. Chandler, Marriage Reform, in REPORT OF THE INTERNATIONAL Council of Women, Assembled by the National Woman Suffrage Association, Washington, D.C., U.S. OF AMERICA, MARCh 25 To APRIL 1, 1888, at 284, 285 (Washington, Rufus H. Darby 1888); see also Elizabeth Blackwell, The Benevolence of Malthus Contrasted with the Corruptions of NeoMalthusianism (1888), in Essays IN MEdiCal Sociology 77, 109 (London, no pub. 1899) (contending that '[ $t]$ he ancient legal oppression, which is still upheld under the title of 'conjugal rights,' is a remnant of that old lustful subjection of the pbysically weaker to the stronger"); Mattie H. Brinkerhoff, Woman and Motherhood, Revolution (New York, N.Y.), Sept. 2, 1869, at 138, 138 ("[1]t should be for [women] to decide when and how often they shall take upon themselves the sacred duties of motherhood ....”).

180. Sarah M. Grimké, Marriage (1852-1857), in The Female Experience: AN American DOCUMENTARY 89, 91 (Gerda Lemer ed., 1977).

181. At the same time, these activists were also particularly aware, as Stanton was, of the distinctive opportunities in public political or intellectual life that might be available to educated and relatively affluent women like themselves, if they could successfully limit the portion of their lives devoted to physical and social reproduction. See supra text accompanying notes 152-153. Gage expressed the keen regret of many of these women when she noted that "without the control of one's own person, the opportunities of the world, which are [the] only means of development, cannot be used." Matilda Joslyn Gage on the Right of Habeas Corpus, BaLLor Box (Toledo, Ohio), Nov. 1876, at 1,1 . 
"[o]ne position, with its attendant round of cares and duties, has ever been acknowledged as especially Woman's-that of Motherhood."182 Sarah M. Grimké elaborated:

Surely as upon her alone devolves the necessity of nurturing unto the fulness of life the being within her $\&$ after it is born, of nursing \& tending it thro' helpless infancy \& capricious childhood, often under the pressure of miserable health; she ought to have the right of controlling all preliminaries. If man had all these burdens to bear, would not he declare that common sense \& common justice confer this right upon him. ${ }^{183}$

\section{B. Structural Consent and Marriage as Legalized Prostitution}

Nineteenth-century feminists often explained that economic and political equality would be meaningless, unless women had the right to their own persons in marriage. The statements reflected their view that equal citizenship needed to be grounded in self-ownership, because a wife's right to control her husband's sexual access would enable her to determine the conditions under which she performed reproductive labor. Yet this point constitutes only part of the feminist claim, and overstates the distinction that these women drew between personal self-possession, and political and economic rights. When feminists elaborated their understanding of consent, they made it clear that they would not be satisfied with legal reform recognizing a wife's right to herself. Instead, they argued that a wife could only freely consent to marital intercourse under circumstances in which she had both the legal right to refuse and realistic alternatives to submission. This was a structural understanding of consent that

182. Chandler, supra note 178 , at 291.

183. Grimké, supra note 180, at 91; see also id. at 95 ("Look at the unnatural tug upon [the] constitution [of a mother of six], her night watches, her sore vexations and trials \& causes nameless \& numberless, that wear away her life. If men had to alternate with their wives, the duties of the nursery, fewer \& further between would be its inmates."). "A Subscriber" to the Woman's Journal made a similar point:

As a mother, a woman goes through the tragedy of giving birth to her son, watches over and cares for his helpless infancy, brings him through all the diseases incident to childhood, is his nurse, physician, seamstress, washerwoman, teacher, friend, and guide, spending the cream of her days to bring him up to be a voter .... Then he leaves home and marries a wife, whom it took some other mother twenty-one years to raise .... Then he votes to help make a law to disfranchise his wife and these two mothers, who have unitedly spent forty-two years of the prime of their days for his benefit, without any compensation. And then he makes another law to compel his wife to do all the same kind of drudgery which his mother had done, with the addition of giving birth to as many children as in his good pleasure he sees fit to force upon her.... It is time we stated facts and called things by their right names, and handled this subject without kid gloves.

After being the recipient of so many favors, such base ingratitude and self-conceit, such arrogant, pompous, unwarrantable, criminal usurpation of power, such supreme selfishness is not to be tolerated or forgiven!

A Subscriber, $A$ Wife's Protest, Woman's J. (Boston, Chicago, \& St. Louis), Mar. 6, 1875, at 74, 74 (emphasis added). 
considered how the structure of the marital relation, rather than simply the behavior of individual husbands, shaped women's opportunities as a class. Feminists noted, and attacked, the tremendous legal, social, and economic pressures that pushed women into marriage and kept them there. A woman who lived outside a husband's household, or (worse yet) divorced or separated, was marginalized and often found it extremely difficult to support herself, given laws and practices that explicitly excluded women from most jobs and suppressed the wages for women's work. ln marriage, coverture principles stripped a wife of almost all legal claims to her household's resources and power, leaving her to confront her husband as an economic, social, and political dependent.

The language of "legalized prostitution" became one of the most powerful idioms in which nineteenth-century feminists articulated this structural understanding of consent. Even before the organization of the first woman's rights movement, Hale and his successors had anxiously recognized the similarities between the situation of wives subjected to the marital rape exemption and prostitutes. As we have seen, these lawyers and judges were never willing, or able, to present a substantive explanation differentiating the work of prostitution from the sexual services that husbands were entitled to take from their financially dependent wives. Instead, the authoritative legal sources sought to distinguish the two classes of women in jurisdictional terms. They argued that only extramarital intercourse could constitute prostitution, that sex could only be illicit and degrading if a woman's sexual partner was not her husband. ${ }^{184}$ The woman's rights movement emphatically rejected that notion and was convinced that it had spotted a crucial weakness in the defense of a husband's conjugal rights. Precisely countering the claims of the exemption's supporters, feminists employed the term legalized prostitution to describe the condition of wives who acquiesced to marital intercourse because they had no practical alternative, nowhere else to go and no other means of negotiating their marital relationship. They argued that the legitimacy of sexual intercourse depended on a woman's genuine consent (understood structurally), contending that there was little relevant difference between married women who effectively traded sexual access in return for their husbands' socioeconomic support, and prostitutes who explicitly sold their sexuality to strangers because they, too, had no better way to earn a living. Legal and illegal prostitution were mirrored phenomena in the feminist vision, understandable on the same terms. ${ }^{185}$

184. See supra text accompanying notes 78-97.

185. As Reva Siegel has shown, the woman's rights movement and doctors opposed to legal abortion engaged in a somewhat different contest over the meaning of "legalized prostitution" in the second half of the nineteenth century. In this debate also, the woman's rights movement used the language of legalized prostitution to criticize women's subordination in marriage and lack of control over their reproductive functions. See Siegel, Reasoning from the Body, supra note 11, at 308. But 
The feminist analysis of illegal prostitution focused on the societal inequities that drove women to the trade, including, very prominently, the inıpedimients that wonien faced in securing a living wage. Feminists understood prostitution as a (highly regrettable) substitute for work in the legitimate market, for women who did not have a husband to support then1. This critique was directed outward; it did not account for prostitution in terms of the internal character flaws or moral worthlessness of its practitioners. Abby Price, a feminist from Massachusetts, explained that "cruel necessity" often drove the prostitute to vice. "The washer-woman," Price elaborated, "works as hard in proportion as the wood-sawyer, yet she makes not more than half as much by a day's work. Thus by narrowing the sphere of woman, and reducing her renuneration of labor so unjustly, her resources are few and she finds it hard to acquire an honorable independence."186 "It is by no means rare," she added, "to see niarried women, widowed, or deserted by their husbands, becoming abandoned, with the sole object of saving their families from dying with hunger."187 Lucy Stone sinilarly identified the causes of prostitution. "Woinen working in tailor-shops are paid one-third as much as men," she noted. Someone had calculated that this wage left women "just three and a half cents a day for bread. Is it a wonder," Stone concluded, "that women are driven to prostitution?" 188 "Is it not time," these women asked, "to throw open to women, equal resources with men, for obtaining honest eniployment?"189

where the defenders of the marital rape exemption were anxious to distinguish marriage and prostitution, the anti-abortion movement embraced the analogy between the current state of marital relations and prostitution, "argu[ing] that marriage was a relation of legalized prostitution so long as man's natural sexual urge were allowed expression in marriage without reproductive consequence." Id. at 309 (original emphasis omitted).

186. Abby H. Price, Address Read to the "Woman's Rights Convention," at Worcester, in ThE Proceedings of the Woman's Rights Convention, Held at Worcester, October 23D \& 24TH, 1850, at 20, 24 (Boston, Prentiss \& Sawyer 1851); see also id. at 26 ("T have the authority of Dr. Ryan, and of Dr. Mayhew, persons of well known integrity ... and they publicly affirm, that nearly all were driven to dissolute lives because there were no means open to them of obtaining an adequate maintenance.").

187. Id. at 25 (citation and internal quotation marks omitted).

188. National Convention at Cincinnati, Ohio, in HisTORY OF WOMAN SuFFrage, supra note 10, at 163,166 (statement of Lucy Stone).

189. Price, supra note 186, at 26; see also Caroline H. Dall, The College, the Market, and THE COURT; OR, WomaN's RELATION to EduCATION, LABOR, AND LAW 135 (Boston, Lee \& Shepard 1867) ("I ask for woman, then, free, untrammelled access to all fields of labor; . . . the question which is at this moment before the great body of working women is 'death or dishonor:' for lust is a better paymaster than the mill-owner or the tailor ...."); Susan B. Anthony, Social Purity (1875), in 2 IDA Husted Harper, The Life and Work of Susan B. ANThony 1004, 1007 (Amo \& N.Y. Times 1969) (1898) ("[Women have] but few and meager chances. Only the barest necessaries, and oftentimes not even those, can be purchased with the proceeds of the most excessive and exhausting labor.... [C] an we wonder that so many poor girls fall ... ?"); Ellen Battelle Dietrick, "Rescuing Fallen Women," Woman's J. (Boston), May 27, 1893, at 162, 162 ("Society says to all women, "Go sew, you belongers in the home, go sew!' ... [A]s a direct consequence of millions of women crowded 
The feminist attack on legalized prostitution in marriage proceeded along the same lines, explaining why wives were not able to exercise free choice with regard to marital relations when they had no good alternatives to acquiescence. "[E]ven in our republic (so called)," Harriot Hunt reported, woman "is denied a finished education, and refused a just remuneration for her labor, and thus has been driven into legal and illegal prostitutions." 190 "[D]ollars and a home come to woman through man."191 Wives "prostitut[ed]" themselves "body and soul," Fuller Walker confirmed, "for the sake of a home, a shelter, or money enough to buy bread that the passions of men may be satisfied." ${ }^{\prime 92}$ While many feminists spoke of legalized prostitution as marrying "for a home," others contended that this description was too mild. Grimké, for instance, argued that marriages where women functionally traded sexual access for support could not accurately be described in a language of domesticity: "Many a woman (I call her not wife)," Grimké noted, "loathes the unhallowed connection she has formed \& would gladly welcome death as a deliverer from that polluted prison house, which the world miscalls her home. A revolting experience has forced upon her the conviction that she is a legal prostitute."193

into a channel of labor which cannot comfortably support more than thousands, a large proportion of them slowly starve or supplement their wages as adviscd by tempters."); Female Labor Question, REvolution (New York, N.Y.), Oct. 29, 1868, at 259, 259 ("Next to the liquor traffic, it is generally conceded that the greatest cause of vice is the inadequate reward of female labor, and the difficulty of woman's obtaining employment at any price."' (quoting Susan B. Anthony)); Helen M. Slocum, The Causes of Prostitution, WomaN's J. (Boston), Jan. 18, 1879, at 22, 22 ("1 have investigated this matter to some extent in New York, and I learn from various sources that want of remunerative employment is the chief cause which leads women first to go down."); id. ("There are in the city of New York, and its immediate vicinity, many thousand women, outside of domestic service, who are compelled to work for wages which do not average over $\$ 2$ pcr week. .. . How long would men hold out against such starvation wages, for the sake of being virtuous ... ?"); The Wages of Work and Sin, Revolution (New York, N.Y.), Oct. 8, 1868, at 221, 221 ("Large establishments that will sccure to women and girls profitable employments will do more to save them from destruction than all the prayer-meetings that can be organized in the John Allen dance-houses.").

190. HaRriot K. HuNt, Glances and Glimpses 201 (Boston, John P. Jewett \& Co. 1856).

191. Id. at 384

192. Fuller Walker, Women Fit for Suffrage, GoLDEN AGE (New York, N.Y.), Sept. 19, 1874, at

2, 2-3.

193. Grimké, supra note 180 , at 94 ; see also id. at 96 ("[M]any so called wives, rise in the morning oppressed with a sense of degradation from the fact that their chastity has been violated, their holiest instincts disregarded, ... and that, too, a thousand times harder to bear, because so callcd husband has been the perpetrator of the unnatural crime."); ADDRESS OF ELIzABETH CADY STANTON, on the Divorce Bili, Before the Judiciary Committee of the New York Senate, in the ASSEMBLy CHAMBER, FEB. 8, 1861, supra note 157, at 7 (explaining that "marriage is, in many cases, a mere outward tie, impelled by custom, policy, interest, necessity; founded not even in friendship, to say nothing of love; with every possible inequality of condition and development"); $i d$. at 8 ("IIs marriage sacred, where a woman] consents to live in legalized prostitution! her whole soul revolting at such gross association! her flesh shivering at the cold contamination of that embrace! held there by no tic but the iron chain of the law, and a false and most unnatural public sentiment?"); id. ("What father could rest at his home by night, knowing that his lovely daughter was at the mercy of a strong man, drunk 
Feminists elaborated on this analysis as it applied to middle-class women outside the wage labor market, but explained the constraints that operated on women who performed market work as well. Stanton, particularly interested in the situation of the middle-class housewife, articulated a multi-tiered set of obstacles to exercising free choice with respect to marital intercourse. The first obstacle, of course, was legal. Marital status law gave women no control over their husbands' sexual demands: "A man in marrying gives up no right; but a woman, every right, even the most sacred of all-the right to her own person."194 Yet that was not the only constraint Stanton saw. If marriage was to rise above "legalized prostitution," wives needed to have "[p]ersonal freedom," something more, even, than a legal right to control marital intercourse. ${ }^{195}$ This freedom "[did] not and [could not] now belong to the relation of wife, to the mistress of the isolated home, to the financial dependent." $" 196$ Middle-class women were systematically trained, in Stanton's view, "to lives of inaction and dependance."197 Indeed, they learned "dependance as a womanly virtue." 198 Marriage gave men enormous legal, economic, and social control over their wives. But women whose families could afford to educate them were taught to shun work in the arts, literature, philanthropy or the academy, which might have provided them with a happy alternative to marriage where they could not find "a pure and holy love."199 Instead, these women were instructed to devote themselves to attracting a husband.

with wine and passion, and that, do what he might, he was backed up by law and public sentiment?'); A History of the Nationai Woman's Rights Movement 22 (Paulina W. Davis comp., New York, Journeymen Printers' Co-operative Ass'n 1871) ("To [Stanton's] lectures, also, is due a healthier tone of public sentiment on the marriage question. It is slowly beginming to be felt that $\mathrm{m}$ that relation there is a vast amount of legalized prostitution, bearing the semblance of virtue, but is rotten below the fair exterior.").

Robert Dale Owen, a prominent divorce reformer, similarly reasoned from domesticity in arguing against restrictive divorce laws on the ground that they permitted marital rape:

Is it her home where [the unwilling wife] is sitting? Let us not so desecrate the hallowed word. A bloated wretch, whom daily and nightly debauch has degraded below humanity, lias the right to enter it. ... He has the command of torments, legally permitted, far beyond those of the lash. That bed-chamber is his, and the bed is the beast's own lair. It depends, too, on the brute's drunken will whether it shall be shared or not. Caliban is lord and master, by legal right. There is not a womanly instinct that he cannot outrage; not a holy emotion that he may not profane. He is authorized to commit what more resembles an infamous crime, usually rated second to murder, and often punished with death, than anything else.

Robert Dale Owen, Divorce, N.Y. DaILY TRIB., Mar. 5, 1860, at 7, 7.

194. Letter from Elizabeth Cady Stanton to Susan B. Anthony (July 20, 1857), in ELIZABETH Cady Stanton, supra note 145 , at $69,70$.

195. Id.

196. Id.

197. Stanton, supra note 143 , at 40 .

198. Id.

199. Id.; see also id. ("Could not fame, distinction, the love of science, of literature, a highly cultivated taste in the arts, the editor's or professor's chair, authorship or philanthropy as fully satisfy the soul of woman, as does the inferior position she now looks to as the summun bonum of all happiness?'). 
"[I]f," Lucy Stone agreed, a middle-class woman went "heartily and bravely to give herself to some worthy purpose, she is out of her sphere and she loses caste." ${ }^{200}$ As a consequence, these women had, Stanton continued, little alternative upon reaching adulthood, but "marrying for a home, a support, a position, a head, a protector, a defender, \&c., marrying to escape the horrors of a single life of inactivity and vacuity, the odious cognomen of old maid." "Tel "Teach woman self-dependance," Stanton advised, "and you end the wholesale degradation of the sacred institution of marriage."202 "[E]ducate woman," Ernestine Rose concurred, "to enable her to promote her independence, and she will not be obliged to marry for a home and a subsistence."203

Of course, it was hardly the worry of poorer women that their lives had been squandered away in frivolity and indolence. Many women had no choice but to engage in market work. The woman's rights movement also described the somewhat different reasons that these women needed more than the legal right to refuse marital intercourse before they would be able to exercise genuine control over their own persons. As the feminists noted, most "profitable employments" were closed to women, and women were paid less for the work they did: "Even for the same services woman generally receives less than man."204 They concluded that "[t]he present condition of woman cause[d] a horrible perversion of the marriage relation." 205 "As a consequence of her fewer resources, marriage has been to her the great means of securing position in society."206 Women had to

200. National Convention at Cincinnati, Ohio, supra note 188, at 166 (statement of Lucy Stonc); see also id. (noting that "the same society that drives forth the young man, keeps woman at home-a dependent-working little cats on worsted, and little dogs on punctured paper").

201. Stanton, supra note 143 , at 40 .

202. Id.

203. Tenth National Woman's Rights Convention, supra note 144, at 732 (statement of Ernestinc L. Rose); see also The Second National Convention in Worcester, in History OF WOMAN SuFfrage, supra note 10, at 226, 238 (statement of Ernestine L. Rose) (" $[I] t$ will be said that the husband provides for the wife.... I wish I had the power to make every one before me fully realize the degradation contained in that idea. Yes! he keeps her, and so he does a favorite horse; by law they are both considered his property."); Grimke, supra note 180, at 96 ("Her imperfcct education unfits her for acquiring that pecuniary indepcndence which would lift her above the tcmptation to marry for a home.... [T] gre great work to be done now for woman by woman, is to impress her with the necessity of pecuniary independence....").

204. Ann Preston's Address, Westchestcr Convention, in History of Woman Suffrage, supra note 10, at 350, 361-62; see also Grimké, supra note 180, at 96 ("Now [women] work under grcat disadvantages and can obtain a mere pittance."); National Convention at Cincinnati, Ohio, supra note 188, at 166 (statement of Lucy Stone) ("The flour-merchant, the house-builder, and the postman charge us no less on account of our sex; but when we endeavor to earn money to pay all these, then, indeed, we find the difference."); id. ("Female teachers in New York are paid fifty dollars a year [a fraction of what male teachers received], and for every such situation there are five hundred applicants.").

205. National Convention at Cincinnati, Ohio, supra note 188, at 166 (statement of Lucy Stone).

206. Ann Preston's Address, supra note 204, at 362; see also National Convention at Cincinnati, Ohio, supra note 188, at 166 (statement of Lucy Stone) ("It is asked of a lady, 'Has she married well?' 'Oh, yes, her husband is rich."'). 
"marry for a home," and were, accordingly, not able to exercise free choice in selecting, or remaining with, a husband. ${ }^{207}$ The marital relation, Ann Preston declared, "which should ever be a 'holy sacrament,' the unbiased and generous election of the free and self-sustained being-too often is degraded into a mean acceptance of a shelter from neglect and poverty!"'208 Woman would not be able to freely choose marriage, until she had "free access to vocations of profit and honor, the means of earning a livelihood and independence for herself!"209

\section{The First Woman's Rights Campaign Against Marital Rape as a Distinctly Nineteenth-Century Movement}

Leading nineteenth-century feminists understood a woman's right to her person as the core foundation on which equal citizenship needed to rest. Their definition of consent to nuarital intercourse, in turn, demanded both a legal right to refuse, as well as the existence of real socioeconomic alternatives to marriage and submission. In many ways, these claims still resonate as distinctly modern. But one should not make the mistake of conflating nineteenth-century feminism with modern claims against the marital rape exemption. ${ }^{210}$

As an initial matter, women were systematically excluded from the bar in the nineteenth century, ${ }^{211}$ and their lack of legal training had important consequences for the shape of the arguments that the first woman's rights movement put forth. Organized feninists clearly wanted to

207. National Convention at Cincinnati, Ohio, supra note 188, at 166 (statement of Lucy Stone).

208. Ann Preston's Address, supra note 204, at 362.

209. Id. at 361; see also Anthony, supra note 189, at 1007 ("To [end prostitution in marriage], girls, like boys, must be educated to some lucrative employment; women, like men, must have equal chances to earn a living.... Marriage, to women as to men, must be a luxury, not a necessity; an incident of life, not all of it.").

210. For a discussion of the modern feminist movement's understanding of the harm that marital rape inflicts upon women, see infra text accompanying notes 434-443.

211. See, e.g., Bradwell v. Illinois, 83 U.S. (16 Wall.) 130, 137-39 (1873) (upholding Illinois Supreme Court's dccision to refuse Myra Bradwell a license to practice law); $i d$. at 141 (Bradley, J., concurring) ("The natural and proper timidity and delicacy which belongs to the female sex evidently unfits it for many of the occupations of civil life. The constitution of the family organization ... indicates the domestic sphere as that which properly belongs to the domain and functions of womanhood."); In re Lockwood, 154 U.S. 116, 116-18 (1894) (holding that Virginia could deny Belva A. Lockwood admission to state bar, even though she had already been admitted to bars of United States Supreme Court and several other states); In re Application of Martha Angle Dorsett to Be Admitted to Practice as an Attorney and Counselor at Law in Said Court (Minn. Ct. C.P. Hennepin County 1876), in SyLLABI, Oct. 21, 1876, at 5, 6 (explaining that lawyers would not be able "to grade up the profession" if women were admitted to the bar, because women's reproductive responsibilities would always prevent them from "bestow[ing] that time (early and late) and labor, so essential in attaining to the eminence to which the true lawyer should ever aspire"); In re Motion to Admit Miss Lavinia Goodell to the Bar of this Court, 39 Wis. 232, 245 (1875) (endorsing women's statutory exclusion from bar on ground that contrary rule "would be revolting to all female sense of the innocence and sanctity of their sex" and "shocking to man's reverence for womanhood and faith in woman, on which hinge all the better affections and humanities of life"). 
establish a woman's right to control the terms of marital intercourse. They meant this to be an independent right, moreover, not one subject to a husband's benevolent agreement. But these women did not clarify what form of enforcement they had in mind. To my knowledge, the woman's rights movement never addressed, for instance, the relative merits of criminal penalties as opposed to civil sanctions for marital rape. Moreover, the movement did not specify whether husbands were to be punished for marital intercourse to which their wives had acquiesced for want of palatable alternatives. The feminists' understanding of genuine consent was significantly more far-reaching than any definition that has ever operated in the criminal law on rape, even outside of the marital context. Criminal rape law focuses on the interaction between the particular victim and perpetrator: who did what when, who said what to whom. But the mineteenth-century feminist understanding of marital rape did not always turn on what an individual husband did or said. It challenged the voluntariness of a wife's consent to sexual intercourse with her husband whenever the wife had no realistic socioeconomic alternatives to marriage and submission, even where the woman's husband had never resorted to force, threats, or coercion. Perhaps the feminists envisioned subjecting "legalized prostitution" to the far lesser criminal penalties associated with illegal prostitution, but they never made that point. Such institutional questions were not of particular interest to nineteenth-century feminism. But to be fair, the judicial opinions and legal treatises of the nineteenth century did not explain the marital rape exemption by reference to institutional claims about the unsuitability of criminal sanctions. The authoritative legal sources argued from an understanding about the nature of marriage that was grounded in an acceptance of women's legal subordination, and the woman's rights movement attacked marital rape on those terms.

Nineteenth-century feminists also had reasons to be wary of marital intercourse that do not neatly map onto the modern landscape. As we have already seen, nineteenth-century feminists built on the premise that women would do all the social work of reproduction, the work of raising children. Rather than highlight issues of bodily autonomy or inviolateness, they understood a wife's right to control her husband's sexual access as the mechanism through which a married woman would determine the conditions under which she performed this labor. A number of other considerations distinctively structured organized feminism's assessment of the risks and rewards of marital intercourse.

Nineteenth-century feminists understood male sexuality to be importantly different from female sexuality. This view did not deny the female sex drive. Indeed, Elizabeth Blackwell, the first woman to graduate from medical school in the United States, devoted much of a treatise to 
disputing the then-common notion that women naturally lacked sexual passion. ${ }^{212}$ But feminists did take male sexuality to be "morbidly developed" in a way that its female counterpart was not. ${ }^{213} \mathrm{On}$ this theory, woman had "more self-control than man;"214 irrational or immoral sexual acts tempted her far less. Stanton was sure that no woman enjoyed acts of prostitution, because "the true woman in her organization [was] too refined and spiritual, to be the victim of an over-powering passion" like that. ${ }^{215}$ In contrast, this view held that lust and licentiousness systematically overrode male rationality and constantly tempted men to commit immoral acts, like insisting on marital intercourse when their wives' health called for restraint. ${ }^{216}$

Although slightly more nuanced, the feminists' dichotomous rendering of the sexual instincts of man and woman drew heavily on a general societal understanding that the female sex drive was far less pronounced and more easily controllable than its male equivalent. ${ }^{217}$ As

212. Blackwell argued "that the assertion that sexual passion commands more of the vital force of men than of women is a false assertion, based upon a perverted or superficial view of the facts of human nature." Elizabeth Blackwell, The Human Element in Sex 56 (London, J. \& A. Churchill new ed. 1894); see also id. at 49. She noted, however, that the sexual interest of wives was highly diminished when they did not want to risk reproduction, remembered awkward or brutal conjugal encounters, or had suffered injuries in childbirth that made intercourse painful. See id. at 49-50. This argument insisted that women had the right to sexual feelings and called for a restructuring of the marital relation so that wives could control the terms of their husbands' sexual access.

Other feminists privately indicated their view that women could be active sexual agents. Stanton, for instance, once remarked in her diary that she had

been reading Leaves of Grass. Walt Whitman seems to understand everything in nature but woman. In "There is a Woman Waitmg for Me," he speaks as if the female must be forced to the creative act, apparently ignorant of the great natural fact that a healthy woman has as much passion as a man, that she needs nothing stronger than the law of attraction to draw her to the male.

Elizabeth Cady Stanton, Diary Entry (Sept. 6, 1883), in Elizabeth CadY Stanton, supra note 145, at 210, 210; see also Elizabeth Cady Stanton, Diary Entry (Feb. 22, 1881), in id. at 183, 183 ("I have come to the conclusion that the first great work to be accomplished for woman is to revolutionize the dogma that sex is a crime, marriage a defilement and maternity a bane.").

213. Letter from Elizabeth Cady Stanton to Lucy Stone and the National Woman's Rights Convention, Cooper Institute, 1856, supra note 156, at 860.

214. Stanton, supra note 143 , at 40 .

215. Id.

216. See Grimké, supra note 180, at 95 ("How often is [the pregnant woman] compelled by various considerations to yield to the unnatural embraces of her husband, and thus to endanger the very existence of her embryo babe. How often is it sacrificed to the ungoverned passion of its own father \& the health of the mother seriously impaired.").

217. For some notable expressions of this view, see William ACTON, THE FUnCtions and Disorders of The Reproductive Organs 162-63 (Philadelphia, Lindsay \& Blakiston 3d Am. ed. 1871) ("[T]he majority of women (happily for society) are not very much troubled with sexual feeling of any kind. What men are habitually, women are only exceptionally. ... [E]ven if [women's sexual feeling is] roused (which in many instances it never can be) it is very moderate compared with that of the male."); id. at 164 ("Many of the best mothers, wives, and managers of households, know little of or are careless about sexual indulgences. Love of home, of children, and of domestic duties are the only passions they feel."); [Nicholas Francis Cooke], Satan In Society 143 (Cincinnati, C.F. Vent 1871) ("While we readily admit and claim for our argument that a woman capable of bearing children 
Nancy Cott has most prominently noted, women had a number of reasons to accept and even promote their reputation for sexual reticence in the nineteenth century. ${ }^{218} \mathrm{Female}$ passionlessness was culturally associated with the premise that the natural inclination of womanhood was to moral seriousness. While women's status as moral exemplars had its own difficulties, it provided a sturdier foundation for respect and equality than earlier, Edenic images of women as sexual temptresses or sexual objects. ${ }^{219}$ The costs of passionlessness for women, moreover, were mitigated. Women did not have the freedom to take many sexual liberties, even if they had been assumed to have interests in that direction. The social and

is also capable of the sexual instinct, the simple fact remains that the majority perhaps-or certainly an immense proportion-of those who have borne children are innocent of the faintest ray of sexual pleasure."); Albert H. Hayes, Physiology of Woman 225-26 (Boston, Peabody Med. Inst. 1869) ("'S]exual feeling in the female, is, in a majority of cases, in abeyance, and ... it requires positive and considerable excitement to be roused at all; and, even if roused (which in many instances it never can be), is very moderate, compared with that of the male."); WILL1AM W. SANGER, THE HiSTORY OF Prostitumion 488-89 (New York, Harper \& Bros. 1858) (“'For] most females [desire] exists in a slumbering state until aroused by some outside influences. ... [W]ithout ... stimulating cause, the full force of sexual desise [sic] is seldom known to a virtuous woman. In the male sex nature has provided a morc susceptible organization than in females ....”).

218. See Nancy F. Cott, Passionlessness: An Interpretation of Victorian Sexual Ideology, 17901850,4 SiGNS 219, 235 (1978) ("[W]omen's participation in the creation of Victorian sexual standards and the place of passionlessness in the vanguard of feminist thought deserve more recognition. The serviceability of passionlessness to women in gaining social and familial power should be acknowledged as a primary reason that the ideology was quickly and widely accepted."); Howard Gadlin, Private Lives and Public Order: A Critical View of the History of Intimate Relations in the U.S., 17 MASS. REV. 304, 318 (1976) ("[T]he nineteenth-century double standard was the vehicle for a desexualization desired by both men and women for opposing purposes. Men wanted to desexualize relationships to maintain their domination; women wanted to desexualize relationships to limit male domination.").

219. Cott explains that:

[P]assionlessness served women's larger interests by downplaying altogether their sexual characterization, which was the cause of their exclusion from significant "human" (i.e., male) pursuits. The positive contribution of passionlessness was to replace that sexual/carnal characterization of women with a spiritual/moral one, allowing women to develop their human faculties and their self-esteem. The belief that women lacked carnal motivation was the cornerstone of the argument for women's moral superiority, used to enhance women's status and widen their opportunities in the nineteenth century.

Cott, supra note 218, at 233; see also John D'Emilio \& Estelie B. Freedman, 1Ntimate MATTERS: A History OF SEXUALity IN AMERICA 71 (2d ed. 1997) ("[M]any middle-class women accepted the view that women lacked innate sexual desire. For one, it provided a means of elevating women to spiritual equality with men."); JoHN S. HALlER, JR. \& ROBIN M. HAller, THE PHYSician AND SEXUALITY IN Victorian AMERICA at xii (1974) ("[T]he Victorian woman sought to achieve a sort of sexual freedom by denying her sexuality, by resorting to marital continence or abstinence in an effort to keep from being considered or treated as a sex object."); CHRISTINE STANSELl, CITY of WOMEN: SEX AND CLASS IN NEw YORK, 1789-1860, at 68 (1986) (“[T]he 'true' woman, powcrfully repudiated misogynist assumptions about the weaker character of the sex and studiously ignored the well-worn tales of Eve's transgressions[, banishing] .... the image of the vain, foolish, sexually duplicitous woman. The dignified Christian woman demanded respect and esteem for her sex.").

For discussions of an earlier, more sexualized understanding of woman's nature, see JOHN DEMOS, A Little Commonwealth: Family Life in Plymouth Colony 82-84 (1970); Laurel. Thatcher UlRich, GoOd Wives: IMAGE aNd REALITY IN THE Lives OF WOMEN IN NORTHERN NEW ENGLAND, 1650-1750, at 89-105 (1982). 
economic penalties for a woman's adultery within marriage and promiscuity or pregnancy before it remained extremely high. ${ }^{220}$ The available empirical evidence on sexual practices, furthermore, suggests that many of the heterosexual experiences that women did have were not pleasurable, with men focused solely on their own sexual satisfaction. ${ }^{221}$

This vision of female sexuality helped structure the nineteenthcentury feminist conversation on marital rape. Widespread agreement about women's lesser sexual interest lent support to feminist efforts to resist men's sexual demands. The image of overdeveloped male sexuality, in turn, gave force to the claim that women needed an enforceable right to control the terms of marital intercourse because they could not assume that their husbands' sexual overtures would be tempered by reason and good moral judgment. Finally, the feminists' understanding that women's sexual desires were less developed led them to discount the potential costs of sexual restraint. The woman's rights movement did not criticize marital intercourse to which the woman had genuinely consented. It would be a mistake to conclude that nineteenth-century feminists were categorically hostile to sex. But they did not express any concern that according women full control over their husbands' sexual access would limit opportunities for sexual expression or sexual pleasure.

The nineteenth-century femimists' opposition to the use of contraceptive devices and abortion also influenced their understanding of the risks of marital intercourse. The first wonıan's rights movement was highly sympathetic to the reasons why women sought abortions. These feminists understood the incidence of abortion, in fact, to be rooted in women's lack of control over marital intercourse, which led desperate women to resort to abortion in order to control their fertility. They blamed the husbands who refused to restrain their sexual demands, rather than the wives forced to submit to them. "Forced maternity, not out of legal marriage but within it, the complete power of the stronger over the weaker sex," femimists explained, "must lie at the bottom of a vast proportion of such revolting outrages against the laws of nature and our common humanity."222 But nineteenth-century feminists still did not endorse

220. See Cott, supra note 218 , at 233 ("[W]omen had to conform to male tastes and wait to be chosen but resist seduction or suffer ostracism for capitulating . ... In sexual encounters women had more than an even chance to lose, whether by censure under the double standard, unwanted pregnancy and health problems, or ill-fated marriage."); HALLER \& HALLER, supra note 219, at xii ("The options open to the Victorians were few. Respectable ladies, even in the privacy of their own homes, had to remain ladies. They could not become promiscuous without attracting the wrath of society ....").

221. See supra text accompanying notes 106-112, 118-130 (discussing Davis and Mosher studies).

222. Child Murder, Revolution (New York, N.Y.), Mar. 12, 1868, at 146, 146-47; see also id. at 146 ("There must be a remedy even for such a crying evil as this [abortion]. But where shall it be found, at least where begin, if not in the complete enfranchisement and elevation of woman?"); A., Marriage and Maternity, Revolution (New York, N.Y.), July 8, 1869, at 4, 4 ("[Husbands] think it impossible that they can outrage [their wives]; they never think that even in wedlock there may be the 
abortion or contraceptive devices as means of regulating reproduction. ${ }^{223}$ Linda Gordon has posited that nineteenth-century feminists feared that separating intercourse from reproduction would facilitate male infidelity, destabilizing marital relationships on which women were enormously dependent, in an environment in which extramarital sexuality remained an unattractive option for middle-class women. ${ }^{224}$ As Reva Siegel has noted, supporting abortion would also have been very politically costly for the feminist movement, given the medical establishment's fierce and organized opposition to abortion in the second half of the nineteenth century. ${ }^{225}$ This focus on limiting intercourse as the only means of curtailing reproduction, however, made nineteenth-century feminists extremely conscious of the costs and perils of each act of marital intercourse. These risks, moreover, encompassed more than the possibility that a woman would have to raise too many children, too quickly. They also included the physiological dangers associated with reproduction. Women still commonly died, or were permanently disabled, by pregnancy and childbirth in the nineteenth century. ${ }^{226}$

very vilest prostitution; and if Christian women are prostitutes to Christian husbands, what can we expect but the natural sequence-infanticide?'); L.B. Chandler, Motherhood: Its Power Over Human Destiny, Woodhull \& Claflin's WEeKLY (New York, N.Y.), May 13, 1871, at 1, 2 ("The practice of feticide is becoming one of the crying evils of our time, and there is but the alternative of an undesigned and undesired maternity, at which the soul of the mother not only shrinks, but stands outraged, ... or a free, unhindered, God-inspired motherhood, never imposed by selfishness and lust."); Child Murder, Revolution (New York, N.Y.), Apr. 9, 1868, at 217, 217 ("[C]ould you look in upon the wretched homes where heartbroken women work ... to provide food for the little ones whom the brutal lusts of a drunken husband have forced upon them, you would not wonder that they did not choose to add to their number."); Gage, supra note 177, at 216 ("I hesitate not to assert that most of this crime of 'child murder,' 'abortion,' 'infanticide,' lies at the door of the male sex."); Grimke, supra note 180 , at 90 ("Has she not, too often, when thus compelled to receive the germ she could not welcome, refused to retain \& nourish into life the babe, which she felt was not the fruit of a pure connubial love?"); Siegel, Reasoning from the Body, supra note 11, at 306-07; GoRDON, WoMAN's BODY, WOMAN's RIGHT, supra note 11 , at 108.

223. See Blackwell, supra note 179, at 115 ("[T] he wife must dctermine the times of union; this is the only natural method of regulating the size of the family.... The [contraceptive] mcthods recommended to women by Neo-Malthusians are ineffectual, and if widely practised will subject women to a more degrading slavery than has hitherto been devised by the insanity of lust."); For Women Only: Mrs. Elizabeth Cady Stanton Discourses on Marriage and Maternity, supra note 157, at 2 ("One lady asked a question which hinted at prevention by other than legitimate means, and Mrs. Stanton promptly replied that such views of the matter were too degrading and disgusting to touch upon, and must be classed in the category of crime alongside of infanticide."); GoRDON, WoMAN's BoDy, WomaN's Right, supra note 11, at 97-I01; Gordon, Why Nineteenth-Century Feminists Did Not Support "Birth Control," supra note 11, at 144-47; Siegel, Reasoning from the Body, supra note 11, at 304-05.

224. See GoRdon, Woman's Body, Woman's Right, supra note 11, at 98, 111, 119.

225. See Siegel, Reasoning from the Body, supra note 11, at 305 n.175, 280-323.

226. See Carroll Smith-Rosenberg \& Charles Rosenberg, The Female Animal: Medical and Biological Views of Woman and Her Role in Nineteenth-Century America, 60 J. AM. HIST. 332, 345 (1973) ("Death from childbirth, torn cervixes, fistulae, prolapsed uteri were widespread 'female complaints' in a period when gynecological practice was still relativcly primitive and pregnancy evcry few years common indeed."); GORDON, WOMAN's BODY, WOMAN's RIGHT, sipra note 1I, at 106; 
Finally, the first woman's rights movement predicted horrific eugenic consequences for the children that unwanted marital intercourse produced. In the second half of the nineteenth century, Americans increasingly understood their country in demographic terms, locating the key constitutive act of nation building in women's reproductive capacity and articulating a wide variety of claims im a eugenic idions. The dominant eugenic argunients of the period endorsed America's hierarchies of national origin and race, contending that this ordering was natural, physiological, and unchangeable. These arguments faulted native-born white women for producing too few children while foreign-born and AfricanAmerican women were producing too nany. The claim featured heavily in the antiabortion literature of the day. Horatio R. Storer, the leader of that campaign, advised native-born white women that "the future destiny of the nation" rested "upon their loins." If unchecked, their supposedly disproportionate propensity for abortion would leave America "filled" with the children of aliens. ${ }^{227}$ Similar fears about the nation's demographic fate lent support to the rash of antimiscegenation laws prohibiting interracial niarriage that states enacted im the aftermath of the Civil War. ${ }^{228}$

Historians have frequently noted that some nineteenth-century feminists directly appealed to this tradition on occasion. In particular, the debates over the Fifteenth Amendnient led some women to make eugenic clainis in support of the contention that native-born white women deserved the vote nore than black men or male immigrants. ${ }^{229}$ But there was niore to the feminist argument about eugemics than this account suggests.

Regina Markell Morantz, Making Women Modern: Middle Class Women and Health Reform in 19th Century America, 10 J. Soc. Hist. 490, 497-98 (1977).

227. HoRATIO ROBINSON STORER, WHy NOT?: A BOOK FOR EVERY WOMAN 85 (Boston, Lee \& Shepard 1866); see also JoHn TODD, SERPENTS IN THE Doves' NEST 16 (Boston, Lee \& Shepard 1867) (anti-abortion tract warning "that while our foreign population have large families, our own native American families are running out, and, at this rate, must and will entirely run out"); Jill Elaine Hasday, Federalism and the Family Reconstructed, 45 UCLA L. REv. 1297, 1344-45 (1998); Siegel, Reasoning from the Body, supra note 11, at 299 "'Translating the creed of manifest destiny into reproductive terms, Storer fused America's populations, territories, and women in a powerful image of reproductive potentiality.... In this vision, the state was its populations, and its identity was determined by the reproductive conduct of its female citizens."); Carroll SmTh-Rosenberg, DISORDERLY CONDUCT: VisIONS OF GENDER IN VICTORIAN AMERICA 238 (1985) "Equally political race-suicide arguments, which, beginning in the 1870 s and 1880 s, put the birth-control and abortion issue in a racist and xenophobic context, also singled out bourgeois matrons as the 'unnatural' perpetrators of 'unnatural' acts.").

228. See Hasday, supra note 227 , at $1344-45$. As one white Southerner articulated the danger of interracial union:

"If we have social equality we shall have intermarriage, and if we have intermarriage we shall degenerate; we shall become a race of mulattoes; we shall be another Mexico; we shall be ruled out from the family of white nations. Sir, it is a matter of life and death with the Southern people to keep their blood pure."

David Macrae, The Americans at Home 297 (E.P. Dutton \& Co. 1952) (1870).

229. Ellen DuBois, for instance, has explained that postbellum suffrage arguments 
Like the dominant purveyors of eugenic theories, the woman's rights movement developed eugenic arguments that supported its moral and legal claims. ${ }^{230}$ At least when feminists described the eugenic consequences of depriving wives of control over their persons, their attention rested on environmental conditions of structured inequality rather than on race or national origin. In the (convenient) thinking of the movement, forced niarital intercourse not only undermined a woman's freedom and equality, it was also eugenically disastrous for her children. Feminists assumed the inheritability of acquired characteristics and contended that a husband's licentiousness and a wife's unhappiness about her impending maternity

contained a strong theme of race antagonism, a reaction to the strategic antagonism between black suffrage and woman suffrage.... Woman suffragists criticized the Fifteenth Amendment because "a man's government is worse than a white man's government" and because the amendment elevated the "lowest orders of manhood" over "the higher classes of women." The racism of such protests was expressed in hints of sexual violence, in the suggestion that women's disenfranchisement would mean their "degradation," "insult," and "humiliation." Those overtly racist arguments reflected white women's special fury that men they considered their inferiors had been enfranchised before them.

DuBois, supra note 13, at 849-51; see also FLEXNER, supra note 23, at 225 ("Another reason for the widening gap between working and more privileged women in the suffrage movement was the antagonism many of the latter felt for the huge and increasing numbers of immigrants.... [T] [Tese women resented the fact that such men, speaking little or no English, stood betwcen them and the vote."); Elisabeth GRIfFith, IN Her OWN Right: The Life of Elizabeth CADy Stanton 124 (1984) ("The insistence of abolitionists and Republicans that black male suffrage take precedence over female suffrage enraged Stanton. In defense she adopted an antiblack, antimale, profemale argument. According to Stanton, it was better and safer to enfranchise educated white women than former slavcs or ignorant immigrants."); Hersh, supra note 13, at 94 ("Like most feminists, [Stanton] found it particularly galling that the 'lowliest white man' (and later the most ignorant black man, whom Stanton contemptuously referred to as 'Sambo') was given suffrage before the most educated woman."); KRADITOR, supra note 136, at 44 ("The suffragists, belonging to the same native-born, white, AngloSaxon, Protestant, middle class as the men who were rethinking the meaning of natural right ['as it applied to the new immigrants'], also began [by the late nineteenth century] to put less emphasis on the common humanity of men and women."); LEACH, supra note 12, at xiv ("[Stanton's] speeches often resonated with elitism, with contempt for the 'ignorant foreigners and other riff-raff' who refused to support suffrage, and with conviction that the 'Saxon race' above all others was 'destined' to 'carry the new gospel of women's equality to all the nations of the earth."' (quoting Women's TriB., July 5, 1890)); MELDER, supra note 136, at 154 ("Paulina Wright Davis and Elizabeth Cady Stanton were more concerned for women's interests than for the needs of blacks, and when offered a choice in the struggle over the fifteenth amendment, between giving the vote to black males and denying it to women, they turned against the Negro."); Gordon, Why Nineteenth-Century Feminists Did Not Support "Birth Control," supra note 11, at 149-50 ("Elizabeth Cady Stanton's appeal for giving the vote to educated women in preference to ignorant men is of a piece with trade unionists' denunciation of Blacks as scabs even as they excluded them from their unions.").

The final version of the Fifteenth Amendment states that: "The right of citizens of the United States to vote shall not be denied or abridged by the United States or by any State on account of race, color, or previous condition of servitude." U.S. CoNST. amend. XV, $\$ 1$.

230. Cf. Siegel, Reasoning from the Body, supra note 11, at 293 (noting that doctors in the second half of the nineteenth century "attacked both abortion and contraception as violations of marital obligation, and, to prove this, emphasized the danger they posed to women's health") (original emphasis omitted). Siegel argues that this "[s]cientific construal of the human body was a form of sexual politics, transposing religious and legal norms into physiological imperatives in a way that obscured questions of "justice and inherent right." Id. at 313. 
would be transmitted to their child before birth, forever diminishing the child's capabilities and prospects. A "corrupt, licentious, drunken brute" had the legal right, a subscriber to the feminist Woman's Journal warned, to "debauch and outrage [his wife's] person," to "force her to give birth to unwelcone children, the exact pattern of the father, to curse the world."231 "Medical jurisprudence," Gage also advised, "has begun to accumulate facts on this point, showing how the condition and feelings of the mother mould not only the physical and mental qualities of the child, but its moral nature."232 "[S]o long as children are conceived in weariness and disgust," Stanton agreed, "you must not look for high-toned men and women capable of accomplishing any great and noble achievement."233

Such arguments demarcated a field of harn, predicting that the adverse consequences of marital rape would be felt intergenerationally. But they also held out the possibility of change and salvation. The leading eugenic theories of the period described large portions of the population as irredeemably inferior, and used that to justify their continued subordination. Feminists, committed to more emancipatory principles, presented the mirror image of that claim, promising that the character of subsequent generations would improve if women had the right to control marital intercourse. Furthermore, where standard eugenic arguments blamed women for using their reproductive capacity unwisely, feminists laid the responsibility for eugenically undesirable children squarely at men's feet, on the ground that men controlled the terms on which reproduction occurred. As intended, these claims only increased what was at stake in marital intercourse. Nineteenth-century feminists sought to establish a

231. A Subscriber, supra note 183, at 74 (emphasis added); see also id. ("The fruit of such marriages fill our alms houses with paupers, our penitentiaries with criminals, our lunatic asylums with incurable maniacs, and our other public institutions with idiots and spendthrifts. Such marriages spread wickedness, misery, ruin, and death, everywhere throughout the world.").

232. Gage, supra note 177 , at 215.

233. Letter from Elizabeth Cady Stanton to Gerrit Smith, supra note 151, at 841; see also Isabella Beecher Hooker, Womanhood: Its Sanctities and Fidelities 15 (Boston, Lee \& Shepard 1874) ("[A] great part of the physical and moral deterioration of the present day arises, it seems to me, from the fact that children are not conceived in the desire for them, and out of the pure lives of their fathers, as well as their mothers ...."); HuNT, supra note 190, at 9-10 ("[T] he reception of every child has much to do with its whole life... . The child accepted as a necessity-nursed and tended grudgingly - has one birthright. But the child, loved and cared for in embryo, and received in the fulness of conjugal, paternal, and maternal love,- has quite another birthright!"); Harriot Stanton Blatch, Voluntary Motherhood, in Transactions of The National Council of Women of the United States, Assembled in Washington, D.C., February 22 to 25, 1891, at 278, 280 (Rachel Foster Avery ed., Philadelphia, J.B. Lippincott Co. 1891) ('Poets sing and philosophers reason about the holiness of the mother's sphere, but men in laws and customs have degraded the woman in her maternity. Motherhood is sacred,-that is, voluntary motherhood; but the woman who bears unwelcome children is outraging every duty she owes the race."); $i d$. at 282 ("Ever since the patriarchate was established there has been a tendency to cramp the mother in her maternal rights; so we see no race improvement comparable with our advance in material science. . . [T] [Te remedy does not lie in depriving women of public freedom, but in according them absolute domestic liberty."). 
wife's control over her husband's sexual access in order to achieve equal citizenship for women. They also insisted that placing the regulation of marital intercourse in female hands was the only way to guarantee the health, vigor, morality, and developmental soundness of the future generation. "Truly," Stanton concluded, "are the sins of the father visited upon the children. God, in his wisdom, has so linked together the whole human family, that any violence done at one end of the chain is felt throughout its length."234

Participants in the nineteenth-century woman's rights movement argued that a wife's right to her own person was the foundation on which women's equality and freedom depended. This view reflected their understanding that the right of self-possession would enable women to determine the conditions under which they raised children. Organized feminists in the nineteenth century, as should be clear at this point, did not contest women's responsibility for this work, or sanction other means of regulating the frequency of childbirth, like contraception or abortion. They saw limiting marital intercourse as the only legitimate method of regulating the work of motherhood and, for precisely this reason, were determined to give control over marital intercourse to wives. Accordingly, where authoritative sources in the criminal law argued that a wife's consent to marital intercourse could be legally and irretrievably presumed from her decision to marry, the woman's rights movement demanded both a legal right to refuse and real socioeconomic alternatives to submission.

\section{III}

\section{Alternate Iterations of the Nineteenth-Century Critique of MARITAL RAPE}

Criticism of marital rape in the nineteenth century was not limited to the members of the organized woman's rights movement. Accounts of the harm that marital rape inflicted on wives appeared in other iterations, both on the fringes of feminism and, more reniarkably, in the popular prescriptive literature on marriage, health, and reproduction. The nature and direction of the causal links between these social conversations is, to be sure, difficult to trace precisely. Most likely, the causation was circular, so that the organized feminist campaign was facilitated by growing

234. Letter from Elizabeth Cady Stanton to Paulina Wright Davis (Oct. 20, 1850), in The Proceedings of the Woman's Rights Convention, Held at Worcester, October 23D \& 24TH, 1850, supra note 186, at 51, 54; see also Tenth National Woman's Rights Convention, supra note 144, at 719 (statement of Elizabeth Cady Stanton) ("Men and brethren, look into your asylums for the blind, the deaf and dumb, the idiot, the imbecile, the deformed, the insane . ... and there behold the terrible retributions of your violence on woman!"); Letter from Elizabeth Cady Stanton to Lucy Stone and the National Woman's Rights Convention, Cooper Institute, 1856, supra note 156, at 860-61 ("[Woman] suffers not alone! Man too pays the penalty of his crimes in his enfeebled mind, dwarfed body, and the shocking monstrosities of his deformed and crippled offspring."). 
opposition to marital rape outside the movement, at the same time that the efforts of organized feminism helped foster and give momentum to this wider opposition. What is striking, though, is that there was a near simultaneous broaching of the question of marital rape in a number of different social communities in the latter half of the nineteenth century, suggesting that the woman's rights discourse about a supposedly unspeakable subject was far more centrist and in dialogue with customary norms than one might have otherwise assumed.

One site of opposition to marital rape outside of the orgauized woman's rights movement in the nineteenth century centered on the advocates of what was then known as "free love." These figures, less the constituents of a cohesive movement than a series of loosely affiliated individual thinkers, occupied the left-most part of nineteenth-century feminism, although at the margins there was some overlap in membership with the woman's rights movement. The free lovers agreed with the essential elements of the organized feminist argument for a woman's right to her own person. But they articulated their critique of the current structure of marital relations more radically and expansively, and called for even more transformative change than the woman's rights movement envisioned. Many members of the woman's rights movement resented the controversial free lovers and labored to disassociate themselves from free love in the popular mind. Yet it is hardly clear that the advocates of free love hampered the woman's rights movement's campaign against marital rape. The work of the free lovers added to the reasoning underlying the organized feminist attack on a husband's conjugal prerogatives. And the free lovers' deliberately provocative style may have made the woman's rights movement appear less radical by comparison.

More importantly, perhaps, the popular prescriptive literature contains powerful evidence that the ferminist campaign against marital rape resonated with changing social norms about good marital behavior. Dozens of mainstream prescriptive writers began to publish extensive discussions of the moral, physiological, and eugenic harm caused by marital rape almost immediately after the organized feminist movement began to address the issue. This literature, however, did not contest a husband's legal right to determine the terms of marital intercourse. Rather, it sought to couvince husbands to voluntarily refrain from exercising their acknowledged legal prerogatives, assuriug them that the accommodation would benefit men as inuch as their wives. Feminists insisted on a wife's right to control her own person, to be pursued in the interest of ending women's inarital subordination. The prescriptive literature certainly helped disseminate societal recognition of the proposition that marital rape inflicted injury on women. But that literature's version of the claim recommended only noncompulsory strategies for marital health, 
happiness, and harmony, to be pursued at a husband's discretion so long as they furthered his self-interest.

Let's begin, though, with the free lovers.

\section{A. The Advocates of Free Love}

The advocates of free love parted company with the nineteenthcentury feminist movement mainly over the ultimate desirability of the marital relation. The woman's rights movement sought to radically restructure marriage so that wives exercised much more power and control within it, but organized feminism endorsed marital monogamy and stability. Free lovers rejected the marriage form altogether. They argued that the law should create absolutely no constraints on consensual love and sex, and understood the prohibition on extramarital intercourse as such a constraint. ${ }^{235}$ In the free love vision, each person had the " right to love when she will, where she will and how she will."'236

235. See Victoria Woodhull, The Beecher-Tilton Scandal Case, WoodHull \& Claflin's WEEKLY (New York, N.Y.), May 17, 1873, at 3, 4-5 ("“[T] he marriage institution ... is now effete, and in a general sense injurious .... I mean by marriage in this connection, any forced or obligatory tie between the sexes, any legal intervention or constraint to prevent people from adjusting their love relations ... in complete personal freedom ...."' (quoting herself)); E.H. HEYwood, Cupid's Yokes: OR, THE Binding Forces of Conjugal Life 22 (Princeton, Co-operative Publishing Co. 1877?) ("Sexual organs are not less sacredly the property of individual citizens than other bodily organs .... The belief that our Sexual Relations can be better governed by statute, than by Personal Choice, is a rude species of conventional impertinence ...."). Thomas Low Nichols and Mary S. Gove Nichols contended that a loveless and inescapable marriage could actually be fatal:

In this marriage a man is bound to live with a woman he does not love, and to renounce all hope of enjoying any intimate relation with any other woman whom he does love; for the law of marriage makes such enjoyment a crime punishable in many States by a long imprisonment. He must support a woman for whom he has no attraction; one who, from the very fact of a loveless marriage, becomes peevish, ill-tempered, and finally diseased. Our graveyards are filled with the corpses of women who have died at from thirty to thirty-five years of age, victims of the marriage institution.... The cares, the responsibilities, the monotony, the dissatisfaction, the disgust, the perpetual struggle between inclination and duty, make life a burthen and death a welcome relief.

T.L. Nichols \& Mary S. Gove Nichols, Marriage: Its History, Character, and Results 84-85 (Cincinnati, Valentine Nicholson \& Co. 1854).

236. A Spicy Time on Free-Love-Very Broad Doctrines Freely Avowed, N.Y. TIMEs, June 29, 1858, at 1, 1 (quoting Julia Branch); see also id. ("I believe in the absolute freedom of the affections, and that it is woman's privilege, aye, her right, to accept or refuse any love that comes to her. She should be the ruling power in all matters of love ...."' (quoting Julia Branch)).

Notwithstanding the charges of their many critics, free lovers did not advocate promiscuity. Indeed, they phrased much of their critique in terms of an attack on the impurity inherent in "fidelity to a legal bond, where there is no Love-where there is Force on one side and Fear on the other." Letter from Stcphen Pearl Andrews to Horace Greeley, in Love, MarRiage, AND Divorce 60, 70 (Stephen Pearl Andrews ed., New York, Stringer \& Townsend 1853) (quoting Mary S. Gove Nichols). "Promiscuity in sexuality [was] simply the anarchical stage of development wherein the passions rule supreme." Vic's Vagaries, CHI. TrMEs, Oct. 17, 1875, at 9, 9 (quoting Victoria Woodhull). "[TT]he very highest sexual unions [were] those that [werel monogamic, and ...these [were] perfect in proportion as they [were] lasting." Id. The free lovers wanted love and intimacy, believed they could only flourish if freely chosen by both woman and man, and concluded that they could only be freely chosen if the state placed no limits at all on their operation. This was not only a normative claim, but a 
Not surprisingly, nineteenth-century conservatives were ferocious critics of free love. They abhorred its rejection of legal marriage, which they took to be a simple promotion of "Libertinism" and licentiousness. ${ }^{237}$ Many-although not all-members of the organized woman's rights movement, in turn, were anxious to distinguish themselves from the more radical free lovers, ${ }^{238}$ particularly since one of the most effective, if

statement of law as well. The free lovers contended that both natural rights theory and the United States Constitution, properly understood, already recognized the liberty they demanded. Victoria Woodhull, one of the most prominent free lovers, explained that she had "an inalienable, constitutional and natural right to love whom [she wanted]; to love as long or as short a period as [she could]."' VICTORIA C. IVoodhull, The Elixir of Life; OR, Why Do We Die? 19 (New York, Woodhull \& Claflin 1873) (quoting herself) (emphasis added). Ezra Heywood argued that "statutes against adultery and fornication, [were] unreasonable, unconstitutional, unnatural and void." HEYwood, supra note 235, at 22 (emphasis added).

237. The Free Love System, N.Y. DaIly TIMES, Sept. 8, 1855, at 2, 2; see also Concerning Free Love, N.Y. DaILY TRIB., July 20, 1871, at 4, 4 ("[Free love destroys] those ideas of conjugal duty, with which society has succeeded for some centuries .... [T] he obligations of fidelity are to last no longer than the [sexual] impulse. ... Mrs. Davis's vagaries may be fun to men, but they are death to women."); Of Free Love, Finally, N.Y. DaILY TRIB., Aug. 1, 1871, at 4, 4 ("These are the only two logical results of the doctrine of Free Love. With pure women ... it means no love at all. With the other kind, it means the promiscuous license of the beasts that perish.").

238. Much talk at the 1869 meeting of the Equal Rights Association, for instance, was devoted to the question of how the woman's rights movement could best distance itself from the advocates of free love. A variety of participants agreed on this goal; they differed only in their analysis of the best strategy for achieving it. Mary Livermore, a feminist from Chicago, wanted the Association to pass a strong resolution endorsing "the sanctity of the marriage relation .... At the West, she said, this woman's movement had to contend against the obloquy of being in favor of the free-love doctrine; she wanted this resolution to rebut that false charge to the fullest extent." Equal Rights, N.Y. TIMEs, May 14,1869 , at 8, 8. Antoinette Brown Blackwell, the first woman ordained as a minister in the United States, "speaking on behalf of New England, agreed with Mrs. L. as to the necessity of making the resolution stronger on this point." Id. Lucy Stone, in contrast, "thought the resolution and the whole discussion concerning it out of place. The subject should not even be hinted in this connection. If any one said that the women who urge this suffrage reform had any affiliation with the detestable doctrine of free love," she declared, "let the lie stick in his throat." Id. Ernestine L. Rose concurred with Stone. She

objected to the resolution on account of its being in effect a plea of guilty. If a man said to her he was not a thief, she would immediately look out for her pocket-book. The prominent workers in this movement had been before the nation a long time, and none dare assert that their moral characters were stained. It was not the thing now, after thirty-three years of toil, and when success was ready to crown their efforts, for the women who desired simply equal political rights for their sex to come out and voluntarily declare that they were not prostitutes. Id; see also 1 HARPER, supra note 189, at 322-26 (similar account of 1869 meeting).

A decade earlier, Saralı M. Grimké had also taken care to "exculpate 'the woman's rights movement,' from the charge of 'tending directly and rapidly to the Free Love system, \& nullifying the very idea of Marriage as anything more than a partnership at will.' On the contrary," she explained, "our great desire is to purify \& exalt the marriage relation \& destroy all licentiousness." Grimké, supra note 180, at 93 (quoting the New York Times).

Not every member of the organized woman's rights movement, however, was so concerned about distancing herself from the free lovers. Stanton, for instance, deeply resented the popular attacks on Victoria Woodhull that focused on her reputation for (un)chastity rather than her political views. "We have had women enougl sacrificed to this sentimental lyper critical, prating about purity," Stanton concluded. "This is one of man's most effective engines, for our division, and subjugation." Letter from Elizabeth Cady Stanton to Lucretia Mott (Apr. 1, 1872) (on file with author; Elizabeth Cady Stanton Papers, Vassar College). Isabella Beeclier Hooker and Susan B. Anthony, in turn, agreed that 
unsubstantiated, charges leveled against the woman's rights movement in the nineteenth century was that it advocated free love. ${ }^{239}$ Nonetheless, the free lovers' willingness to operate at the left-most reaches of public discourse may have helped deaden the shock of the mainline feminists' only somewhat more moderate claims. Moreover, for all the differences between free love and organized feminism on the value of the marriage form, the free lovers' attack on marital rape was closely aligned to that articulated by the woman's rights movement, even if couched in a more explicit and provocative idiom. The free lovers constituted another set of voices making the femimist case for a woman's right to self-possession.

The free lovers agreed with organized feminism that a woman's control over her own person was the necessary foundation for her equal citizenship. ${ }^{240}$ They characterized a husband's sexual imposition on his unwilhing wife as the violation of a "Woman's Natural Right to ownership of and control over her own body-self,- - a right inseparable from Woman's intelligent existence; a right unquestionable, precious, inalienable, real-beyond words to express."241 But where the organized feminist movement's critique of marital rape left its preferred mode of enforcement unspecified, the free lovers charged-at great length and to tremendous publicity-that unwanted sex in marriage was no different from the nonmarital outrages already prohibited and severely punished in criminal rape statutes. "Night after night there are thousands of rapes cominitted," Victoria Woodhull reported, "under cover of this accursed [marriage] license." "The world has got to be startled . . . into realizing that there is nothing else now existing among pretendedly enlightened nations, except marriage, that invests men with the right to debauch women, sexually, against their wills." ${ }^{433}$ "To the unmarried woman," Thomas Low Nichols and Mary S. Gove Nichols added, "a rape, or the violent possession of her person, is an outrage, which the laws of most countries punish with death." Yet after the marriage ceremony, "not only does the law justify the outrage, but she is severely blamed by a virtuous

the woman's rights movement should avoid criticizing Woodhull in public. See Letter from Isabella Beecher Hooker to Snsan B. Anthony (Mar. 11 and 14, 1871), in The Limits of Sisterhood: The BeECher Sisters on WOMEN's Rights AND WOMAN's SPHERE 205, 206-09 (Jeanne Boydston et al. eds., 1988).

239. See, e.g., The Free Love System, supra note 237, at 2 ("The Woman's Rights movement tends directly and rapidly in the same direction [as free lovel,- that extreme section of it, we mean, which claims to rest on the absolnte and indefeasible right of woman to an equality in all respects with Man, and to a complete sovereignty over her own person and her conduct.").

240. See Nichols \& Nichols, supra note 235, at 117 ("Woman's one, single, and supreme right, and the one which includes all others, is her right to herself.").

241. [EzRa H. Heywood, Free SPEech: Report op Ezra H. Heywood's Defense Before the United States Court in Boston, April 10,11 and 12, 1883, at 16 (Princeton, Co-operative Publishing Co. 1883?).

242. Victoria C. Woodhull, TRIEd as by FiRE 8 (New York, Woodhull \& Claflin 1874).

243. Id. 
society for not submitting to the man, to whom her person, her whole being forever belongs!"244

The free lovers also compared a wife's sexual subjection im marriage to slavery. This was the most powerful reformist analogy available in postbellum America. After generations of debate over slavery and four years of war, the nation had just declared that particular form of subordination to be illegitimate. It was an open, and highly contested, question just how far the logic of freedom and equality that had undergirded the emancipation of the slaves would be permitted to extend in the postbellum period. But it was clear that other status relations would be more vulnerable the more they were understood to resemble slavery. The advocates of free love, taking full advantage of the rhetorical possibilities, constantly described marital rape in the language of bondage. Wives, they said, were "Sexual Slaves."245 Under "legal sexual slavery,"246 a wife's duty was "submission."247 Her husband's will was "her only law." ${ }^{248}$ Indeed, in the decade before the Civil War, the Nicholses had devoted an entire chapter of their work on marriage to the parallel between a wife and a slave. ${ }^{249}$ This discussion drew a specific analogy to the systermic sexual exploitation of slave women by white men, which was a constitutive element of chattel slavery in the Umited States. ${ }^{250}$ The Nicholses advocated abolition,

244. Nichols \& Nichols, supra note 235, at 102; see also id. at 336 ("[The crime of rape] exists chiefly in the marriage relation."); [MOSES HARMAN], THE NeXT REVolution: OR WOMAN's Emancipation from Sex Slavery 7 (Valley Falls, Lucifer Publishing Co. 1890) (condemning "legalized rape" in marriage).

245. HARMAN, supra note 244 , at an unnumbered back page.

246. Victoria C. Woodhull, The Scare-Crows of Sexual Slavery 22 (New York, Woodhull \& Claflin 1874); see also id. at 21-22 ("I hope I may break up every family in the world that exists by virtue of sexual slavery,... . [I will] stand even upon the scaffold, if need be, that my sisters all over the world may be emancipated, may rise from slavery to the full dignity of womanhood."); $i d$. at 22 ("Marriage slavery has slaughtered more women than ever there were men slaughtered on the gory fields of battle.").

247. Nichols \& Nichols, supra note 235 , at 85.

248. Id.; see also id. at 306 (condemning "the domestic servitude of marriage," in which wives are subject to "involuntary, compulsory, and repugnant maternity"); Letter from Theresa Hughes to the Lucifer (Apr. 26, 1890), reprinted in HARMAN, supra note 244, at 63, 63 ("She [the author's married friend] was a slave in every sense of the word, mentally and sexually, never was she free from his brutal outrages, morning, noon and night, up almost to the very hour her baby was born, and before she was again strong enough to move about."); WoODHULL, supra note 242 , at 37 ("[A] woman ... is compelled to submit herself, sexually, to a legal master whenever he demands it, even to the extent of brutality!'); Letter from Stephen Pearl Andrews to Horace Greeley, supra note 236, at 70 (identifying a wife as "'a legal slave"" to her husband's sexual demands (quoting Mary S. Gove Nichols)); $A$ Spicy Time on Free-Love-Very Broad Doctrines Freely Avoved, supra note 236, at 1 ("Why should woman tame herself into calm submission, and be the slave and toy and play-thing of man? ... Women are bought and paid for, as the negro slave is." (quoting Julia Branch)).

249. See NichoLs \& NicHoLs, supra note 235 , at 90-96.

250. For a discussion of sexual exploitation under slavery and the abolitionist advocacy that contested it, see Hasday, supra note 227 , at 1332-34. 
defined broadly to include all forms of sexual subjugation that denied a woman-slave or wife-the right to refuse a man's sexual demands. ${ }^{251}$

In criticizing marital rape, the free lovers stressed that a woman needed control over her own person in order to determine the conditions under which she performed the work of raising children. ${ }^{252}$ But the free lovers' focus on the work of motherhood was not particularly tight. In contrast to the leaders of the organized woman's rights movement, who

251. Indeed, in their enthusiasm to make the connection between marital rape and slavery, the Nicholses contended that a wife's sexual vulnerability to her husband was actually more absolute than a slave woman's vulnerability to her master, the (highly unconvincing) theory being that any one slave had a greater chance to escape her master's notice and abuse than a wife had to escape her husband's notice and abuse:

The female slave may be compelled to submit to the embraces of her master-the wife is compelled to submit to the embraces of her husband, however disagreeable, painful, revolting, or dangerous to health and life....

The female slave has little chance of choosing who shall be the father of her childrenthe civilized wife has still less power of choice. ... [T] one [marriage] in a thousand. ...

The master may be a kind and benevolent man, giving his slave every indulgence; so may the husband; but the wife, in vital matters coneerning the affections, is far less likely to be indulged in freedom than the slave.

Nichols \& Nichols, supra note 235, at 93-94. Fifteen years later, John Stuart Mill offered an even more extreme version of the same argument in The Subjection of Women first published in England in 1869. Mill also charged that women were more sexually subordinated in marriage than in slavery, but his claim turned on the wholly inaccurate premise, see supra note 250 and accompanying text, that a female slave had the right to reject her master's sexual advances outright. As Mill explained:

Above all, a female slave has (in Christian countries) an admitted right, and is considered under a moral obligation, to refuse to her master the last familiarity. Not so the wife: however brutal a tyrant she may unfortunately be chained to-though she may know that he hates her, though it may be his daily pleasure to torture her, and though she may feel it impossible not to loathe him-he can claim from her and enforce the lowest degradation of a human being, that of being made the instrument of an animal function contrary to her inclinations.

John Stuart Mill, The Subjection of Women 33 (Susan Moller Okin ed., Hackett Publishing Co. 1988) (1869). For a discussion of the nineteenth-century feminist campaign against marital rape in England, see Mary Lyndon Shanley, Feminism, Marriage, and the Law in Victorian ENGLAND, 1850-1895, at 156-88 (1989).

252. Woodhull "protest[ed] against the custom which compels women to give the control of their maternal functions over to anybody. It should be theirs to determine when, and under what circumstances, the greatest of all constructive processes-the formation of an immortal soul-should be begun." Victoria C. Woodhull, A Speech on the Principles of Social Freedom 36 (New York, Woodhull \& Claflin 1874). Woman, Eliza W. Farnham explained, had an "'indefeasible right"” to "'that freedom and control of her person in the marriage relation which alone would enable her to consult her nature, and its physical and spiritual capacity to assume at any time the office of mother." A Spicy Time on Free-Love-Very Broad Doctrines Freely Avowed, supra note 236, at 1 (quoting Eliza W. Farnham); see also id. ("'[W]omen of the Nineteenth century! The marriage institution gives you one right ... the right to bear children.... [I]t is the law of wise men, who know very much better than you do when you want a child, and when you ought to become a mother." (quoting Julia Branch)); HeYwooD, supra note 241, at 9 ("Do you believe that maternity is a matter concerning which women should be consulted, that they should do therein what seems to them right and best; or do you think it right or expedient to subject women to forcible impregnation ... ? In other words are you opposed to Rape?"); NicHOLS \& NichOLS, supra note 235, at 102 ("[Women are] compelled to submit to the toils and sufferings of a maternity for which they have no desire... [T] bear children against her own will, is a part of the marriage system ...."). 
concentrated on limiting the downside risks of sexuality for women, the advocates of free love also justified a woman's right to control her husband's sexual access by reference to rights of the body: namely, female sexual autonomy and pleasure. Woodhull, who always made the woman's rights movement seem substantially more traditional by comparison, was concerned about wives who were sexually unfulfilled because "compelled to undesired relations with the legal owners of their sexual organs."253 "The mind," she elaborated, "in rebellion at the enslaved condition, has such an effect upon the sexual act that it becomes impossible for [the woman] to respond or reciprocate." 254 In Woodhull's view, sexual apathy actually threatened a wife's health and longevity. She cited medical authority for the proposition that: "If the [sex] act is complete, so that both body and mind are satisfied, no disease arises, though there be frequent repetitions; but if the act be incomplete, the organs being irritated merely, and the mind not satisfied, then disease will surely follow." 255 The Nicholses concurred in finding that " $t]$ he apathy of the sexual instinct in woman is caused by the enslaved and unhealthy condition in which she hives."256 "A healthy and loving woman," they reported, "is impelled to material umion as surely, often as strongly, as man.'257 These women were, the couple warned, "destroyed by being made bond-women." 258

The free love critique of forced oral sex in marriage was another sign of their concern with women's sexual autonomy and pleasure, as well as their willingness to delve publicly into topics that brought the issue of marital rape to the fore even as they made the orgamzed woman's rights movement seem almost tactful by comparison. The conduct here was necessarily not procreative, but many women in the nineteenth century thought oral sex was inherently degrading. The issue was whether a wife had the right to refrain from sex acts in which she did not want to

253. WoODHULL, supra note 236 , at 9.

254. WoODHULL, supra note 242 , at 42.

255. Id. at $42-43$ (quoting Dr. John M. Scudder, Professor of the Diseases of Women in the Cincinnati Medical College); see also id. at 43 ("Therefore,' he adds, 'the wife should not lose control of her person in marriage. It is hers to rule supreme in this regard."' (quoting Scudder)). A correspondent to Moses Harman's Lucifer offered a similar diagnosis in describing the plight of a woman whose "health and strength left her after her marriage." The writer surmised that:

This would not have occurred, however amative her husband might have been, if he had been kind and careful, but instead, he played the brute the first night after their marriage. To use her own expression, "he went to work like a man a mowing," and instead of a pleasure as it might have been, it was most intense torture.

He kept this up for a little less than a year, then, as you know, she was laid in the grave, and he is just as much her murderer, as though he had killed her in any other manner.

I believe that a strong, healthy, well organized woman will have sexual desires, and if less so than man, it is because she is less active in the fresh outdoor air.

Letter from Sadie Athena Magoon to the Lucifer, reprinted in HARMAN, supra note 244, at 8, 9.

256. NicHOLs \& NichoLs, supra note 235, at 202.

257. Id.

258. Id. 
participate, even when the possibility of maternity was not at stake. The free lovers answered that question, not surprisingly, with a resounding yes. The Lucifer, a journal devoted to free love principles, published a series of letters in 1890 detailing the particular humiliation that wives experienced upon being compelled to perform oral sex. "I know of one case," one correspondent reported, "where a man when his wife was so near her confinement that he did not care to enforce his claim in the natural way, forced her to relieve him by making a 'sucker' of her and she would vomit with the disgust and nausea thus caused." 259 "So long as these revolting, disgusting, horrible things are," these writers agreed, "they may as well be made known, that they may be done away with. The fact that they do exist is enough to make any person having any humanity in them, struggle to enlighten the race on the right use of sex."260

Like the organized woman's rights movement, the free lovers went on to demand more than a wife's legal right to refuse. They also condemned the structure of marriage more generally, joining organized femimism to explain that wives functioned as legalized prostitutes whenever they had no realistic alternatives to marriage and submission. ${ }^{261}$ Woodhull, like Stanton and Stone, repeatedly stressed that women would never achieve sexual freedom until they were "self-reliant and self-supporting individuals," 262 no longer "dependent upon [men] for the means of subsistence."263 "Sexual relations," she declared, "should be the result of entirely different motives than for the purpose of physical support." 264 The

259. Letter from Lois Waisbrooker to Moses Harman, editor of the Lucifer (Mar. 27, 1890), reprinted in HARMAN, supra note 244, at 35,36. "The young man of whom I knew," added a second writer, "threatened his bride of a week with a sharp knife in his hand, to compel her to perform the office of "sucker." Letter from Lucinda B. Chandler to the Lucifer, reprinted in id. at 48, 49. Another wife successfully resisted her husband's demands, but not before "he dragged her out of bcd, kickcd, choked, pinched and bit her, and then left her lying on the floor unconscious." Letter to Moses Harman, editor of the Lucifer, reprinted in id. at 13,14.

260. Letter to Moses Harman, editor of the Lucifer, reprinted in id. at 13, 14.

261. See WoODHuLL, supra note 246, at 24 ("[A] blessed emancipation shall dawn for womankind, such as eye hath not seen nor heart conceived, in which no woman will ever even seem to be compelled to sell her body to any man for a permanent home, or for the means to procure a temporary one."); WoODHULI, supra note 242, at 19 ("In the exact sense, the woman who sells her body promiscuously is no more a prostitute than she is who sells herself in marriage without love. She is only a different kind of a prostitute."); $i d$. at 43 ("Sexual freedom, then, means the abolition of prostitution both in and out of marriage; ... means the end of her pecuniary dependence upon man, so that she may never even seemingly, have to procure whatever she may desire or need by sexual favors ...."); Sixteenth Amendment. Woman as a Social Element., WoodHuLL \& ClAFLIN's WeEkLY (New York, N.Y.), May 28, 1870, at 4, 4 ("Public prostitution is but nothing compared to that practiccd under the cloak of marriage. The latter is increasing to such an extent as to threaten the existence of the former.").

262. WoODHULL, supra note 252 , at 35 .

263. Sixteenth Amendment. Woman as a Social Element., supra note 261, at 4.

264. WoodhulL, supra note 252, at 35. Stephen Pearl Andrews seconded the view that woman would not control her own person until she "possess[ed] the Freedom to bestow herself according to the dictates of her own affections, wholly apart from the mercenary considerations of shelter, and food, and 
free lovers ultimately rejected the marriage form entirely, going significantly beyond what the woman's rights movement endorsed. ${ }^{265}$ But the free lovers' analysis of marriage as it was currently constituted resonated deeply with the organized feminist effort against marital rape.

Feminists across the spectrum in the latter half of the nineteenth century agreed that a husband's conjugal rights were a crucial constitutive element in women's subordination and campaigned for a wife's right to her own person. The advocates of free love offered a critique of marital rape which reinforced that advanced by the organized woman's rights movement, even as the free lovers spoke in a more radical and explicit voice. But feminists were not alone in their opposition to marital rape. Very soon after feminists began to address the question, the popular prescriptive literature on marriage started to broach the subject as well.

\section{B. The Popular Prescriptive Literature}

The prescriptive literature on marriage in the second half of the nineteenth century was preoccupied with warning husbands to refrain from marital intercourse when they did not have their wives' consent. Popular authors, like the woman's rights reformers, were remarkably frank, even verbose, in their discussion of the issue. ${ }^{266}$ Marriage manuals, written by both men and women and widely read, warned husbands that subjecting one's wife to marital intercourse when she did not want to risk the possibility of motherhood was immoral and dangerous to the health of

raiment." Letter from Stephen Pearl Andrews to the editor of the New York Tribune, in Love, MARRIAGE, AND Divorce, supra note 236, at 39, 47; see also HeYwood, supra note 235, at 21 ("In marriage,] social pleasure, being an object of common desire, becomes a marketable commodity, sold by her who receives a buyer for the night, and by her who, marrying for a home, becomes a 'prostitute' for life."); Nichols \& Nichols, supra note 235 , at 85 (describing the sufferings of a wife who "has married for a home-for position-because her friends will not hear of her refusing a good offer" and now finds "[h]er body ... prostituted to [her husband's] morbid passions").

265. See supra notes 235-236 and accompanying text.

266. This literature did not take mutual consent to be a sufficient condition for marital intercourse. It opposed all intercourse where reproduction was not sought and desired, instructing readers that "[p]assional enjoyment must be made wholly incidental, never pursued as an end." Nicholas E. Boyd, To the Studious and Thoughtful, in Dio LewIS, Chastity; OR, OUR SECRET Sins 312, 316 (Philadelphia, George Maclean \& Co. 1874). But it did advise husbands to accept mutual consent as a necessary condition for marital sex. See also id. ("It is right, then, to exert the sexual function when children are desired, and rightly desired, and only then ...."); JoHN COWAN, THE SCIENCE OF A NEW LIFE 112-13 (New York, Fowler \& Wells Co. 1869) ("[S]exual connection was intended only for the propagation of the species; for had God intended it otherwise, He would, in the greatness of His wisdom, have adapted some peculiarity of structure in the sexual organism that would have enabled mankind to exercise the lustful of their natures without the danger of impregnation following."); E.B. Duffey, The Relations of THE SeXes 235 (New York, M.L. Holbrook \& Co. 1885) ("It is a solemn thing to evoke a human being to life-a being ... whose everlasting good or ill may depend directly upon ourselves. Are we justified, then, in calling such a being lightly into existence, at a lustful impulse, and then blasphemously throwing the responsibility upon God?"). 
man, woman, and unwillingly produced child. ${ }^{267}$ They called on husbands not to exercise their legal prerogatives and proposed a wide array of stratagems to facilitate that result. In this way, criticism of marital rape registered and reverberated in a wider popular conversation about intimacy in marriage in the nineteenth century.

It is important to recogmize, however, the differences between the feminist rights discourse on marital rape and the work of mainstream prescriptive writers. First, the popular prescriptive literature focused on each individual husband's behavior. These texts wanted husbands to refrain from nonphysical coercion, as well as physical force compelling a wife to submit to marital intercourse. But their understanding of a wife's consent did not include the structural concerns about marriage that occupied feminists; these writers did not suggest an inquiry into the limited economic and social opportunities that pushed women into marriage and kept them there.

More fundamentally, the operative premise behind the popular prescriptive literature's argument for a husband's voluntary restraint was that he had the authority to act differently. This literature explicitly addressed social norms, rather than the law. Yet the two were never fully separable. The law shaped the prescriptive literature's understanding of society, even as that literature urged husbands to act better in practice than the law required. The prescriptive literature's entire discussion of manly selfrestraint assumed and accepted the baseline proposition that a husband had the right to control the terms of marital intercourse. He might be persuaded not to avail himself of that entitlement, by tracts promising that marital mutuality would benefit a husband at least as much as his wife. But prescriptive writers acknowledged that the choice was ultimately his. This was the very proposition that the woman's rights activists vigorously disputed. Nineteenth-century feminists explained a husband's conjugal prerogatives as an instrument of women's subordination and demanded rights that women could enforce against their husbands. In the prescriptive literature, this rights discourse was transformed into suggested strategies for marital health, happiness, and harmony, to be pursued in a husband's interest and at his discretion.

267. A number of the women that Mosher surveyed, for instance, reported having carefully reviewed the popular prescriptive literature on marriage bcfore their own weddings. Sevcral women specifically cited Alice Stockham's Tokology. See MosHer, supra note 113, at 21 (Blank No. 2); id. at 29, 41 (Blank No. 3); id. at 111 (Blank No. 10). Others mentioned John Cowan's The Science of a New Life, see id. at 195 (Blank No. 17); id. at 273 (Blank No. 24), works by George Napheys,see id.; id. at 299 (Blank No. 26), and works by R.T. Trall, see id. at 21 (Blank No. 2). One woman reported having read the "best pages" of Orson Squire Fowler. Id. at 273 (Blank No. 24). 


\section{The Prescriptive Account of the Harm of Marital Rape}

Like the nineteenth-century feminists, prescriptive writers elaborated at length on the harm that marital rape inflicted. But the prescriptive literature's focus was not on wives alone. This literature warned that marital rape inflicted severe injuries on wives that were morally untenable. It went on, however, to report that marital rape ultimately operated against a husband's self-interest as well, appealing directly to the party who retained the right of control.

Prescriptive writers put forth three prominent moral arguments explaining the harm that marital rape caused wives. These arguments were not feminist in their reasoning; they did not consistently recognize the fundamental equality of men and women. But they were real and empathetic nonetheless. The prescriptive literature's first moral argunent was grounded in a view of the animal world, which supposed that intercourse among lower animals was always under the female's control. This argument, in essence, was a claim that women should be treated as well as other female animals, not a claim for women to be treated as well as men. Although put forth in an effort to mitigate the functional consequences of women's subordination to nien, the argument did not challenge that hierarchical ordering. ${ }^{268} \mathrm{It}$ simply contended that what was natural (and therefore right) for lower aninials, was right for women as well. When R.T. Trall declared that "GoD and Nature have given to the fentale the supreme control of her own person," he cited the practice of "[t]he whole animal kingdom below man" as his sole piece of supporting evidence. "269 "No male animal offers violence to the fentale," Trall explained. "[H]e never compels her to submit to the sexual embrace against her desire, nor forces her to bear offspring against her inclination or will. But, when she is in condition to propagate her kind, and desires the co-operation of her male partner, she informs him of it."270 William McLaury similarly advised husbands to "take a lesson from the lower aninuals, and not coerce or over-persuade, but await the wife's invitation at this time.".271

268. Indeed, only a few of the prescriptive authors ever spoke in terms of human nature and a woman's human rights. Sylvanus Stall explained that a woman, as "a free moral agent," was fully capable of assuming responsibility for the regulation of her own maternity and had a "personal right[]" to do so. Sylvanus Stall, What a Young Husband Ought to Know 152 (Philadelphia, Vir Publishing Co. 1897). A wife, Eliza Duffey added, did "violence to her own moral nature, by yielding unwillingly to demands or pressing importunities." DUFFEY, supra note 266, at 209; see also HAYEs, supra note 217, at 54 ("The conjugal embrace should never be indulged in against her [the wife's] wishes. ... She is a free, moral agent, as well as himself.").

269. R.T. Trall, Sexual Physiology: A Scientific and Popular Exposition of the Fundamental Problems in Sociology at xi (New York, Miller, Wood \& Co. 4th ed. 1867).

270, Id.

271. Wm. M. McLaury, Remarks on the Relation of Menstruation to the Sexual Functions, 20 AM. J. OBSTETRICs 158, 161 (1887). Orson Fowler agreed: "This is the "male and female' law throughout all the kingdoms of animal, feathered, and even insect life," he wrote. "In no single instance, except 
Marriage manuals also argued that women should control their husbands' sexual access because wives would have to do the work of bearing and nursing any children conceived. Grounded in a gender-specific appreciation of the work that women performed, this argument did track the predominant feminist claim for a wife's right to her own person. The feminist reformers focused on the work of raising children, identifying it as the most time-consuming and taxing part of motherhood. The prescriptive literature spoke about the physiological aspects of reproduction (childbirth and lactation), a form of labor that was perhaps easier for a popular audience to recognize as onerous work. John Cowan explained that a wife needed the right "to her own person-the right to deny all approaches, save and only when she desired nuaternity," 272 because she bore all of the risks of gestation and childbirth: "[t] he pains, the troubles, the heart-burnings, the sickness, the danger of premature death."273 "[J]ustice and reason dictate," Nicholas Boyd agreed, "that she who feeds the unfolding germ with her very life-blood, endures the pangs of travail and nurses the babe at her own breast, should be left to decide freely, without compulsion or entreaty, when she is ready to undertake the holy office of n1aternity."274

among human, does the male ever obtrude himself upon the unwilling female." O.S. FowLER, SExuAL SCIENCE 682 (Philadelphia, National Publishing Co. 1870). Even Stall relied on evidence from the animal kingdom: "[A]ny one who has given attention to the reproductive act among animals," he reported, "will have noticed that in no instance can the male force this relation upon the female without her acquiescence, and in most instances the time of copulation is wholly determined by the condition of the female." STALL, supra note 268, at 128 . Stall could not "but believe that this is also intended to be the rule among human beings." Id.; see also Boyd, supra note 266, at 318 ("It is for the fernale to determine when impregnation shall take place. Observing the lower animals alone would favor this conclusion ...."); Letter from Mrs. Z.R. Plumb to M.L. Holbrook, in PARTURITION Without Pain; A Code of Directions for Escaping from the Primal Curse 124, 126 (M.L. Holbrook ed., New York, M.L. Holbrook 14th ed. 1882) ("'Enforced and unwilling maternity is not the habit of the brute; why of the human, so-called, enlightened world?"').

272. CowaN, supra note 266 , at 394 .

273. Id. at 109.

274. Boyd, supra note 266, at 318-19. It would, Dio Lewis concurred, be "a tyranny and outrage" for a wife to have no "right to deny her husband," whcre every "sexual intimacy mean[t] a possible pregnancy with all its deprivations and discomforts, a parturition with all its sufferings and dangers, a long period of lactation-in brief, motherhood, with all its weighty responsibilities and incessant labors." Lewis, supra note 266, at 18-19; see also E.B. DUFFEY, WHAT WOMEN SHOULd KNOW 13233 (Philadelphia, J.M. Stoddart \& Co. 1873) ("[The woman] has to endure the pains, penalties and responsibilities [of bearing children], both before and afterward, and she can best judge of her fitness and her powers of endurance.... [I]t is the extreme of cruelty for her husband to force child-bearing upon her."); HAYES, supra note 217, at 54 ("The conjugal embrace should never be indulged in against [the wife's] wishes. The husband may have the power, but he is a brute, if he imposes upon his wife the pains of labor and the perils of maternity against her consent."); TRALL, supra note 269, at 202 ("It is for [woman] to nourish and sustain the new being; it is her health and life that are directly imperiled by being compelled to bear children .... [I]t is her absolute and indefeasible right to determine when she will, and when she will not, be exposed to pregnancy."); Henry C. WRight, The UNwelcome ChILD; OR, THE CRIME of AN UNDESIGNed AND UNdesiRed MATERnity 23 (Boston, Bela Marsh 1858) ("Who shall say how often, for what purposes, and under what conditions, the wife shall subject her person to 
Finally, the postbellum prescriptive literature's last moral argument in favor of voluntary restraint warned husbands that subjecting an unwilling wife to marital intercourse meant treating her like a prostitute, a fundamentally immoral and degrading course of action. As this commentary repeatedly explained, prostitution could exist inside marriage under essentially the same terms on which it operated outside the marital relation. ${ }^{275}$ When femimists made this point, they used it to draw attention to women's socioeconomic dependence on their husbands and to indicate how this inequality hampered women's ability to refuse marital intercourse. ${ }^{276}$ The prescriptive literature took a somewhat different tack: These writers argued that the essence of prostitution, inside marriage and out, was a sex act in which the man used the woman simply to satisfy his sexual desire, without any attempt to modify his sexual demands and without any concern, more generally, for the woman's welfare or state of mind. Eliza Duffey described wives "who feel that they bear the brand of the prostitute within their souls, because they are forced to yield their bodies unwillingly to gratifying that which they can regard in no other light than as a selfish lust, hallowed as it is by no mutual desire, nor exalted by self-forgetting impulses."27 As an article entitled Prostitution Within the Marriage Bond concluded, "marriage, home, and posterity are alike dishonored when women are forced to submit to sexual abuses whicl are revolting to their souls."278 "He is an ill luusband," Sylvanus Stall agreed, "that uses his wife as a man treats a harlot, having no other end but pleasure."279

The prescriptive literature supplemented these moral claims against marital rape with a series of physiological arguments that made clear that the injury caused by marital rape was not limited to wives. This literature warned that the practice of marital rape actually endangered the liealth of

a relation which renders her liable to become a mother, and to the suffering and anguish of developing and giving birth to a child?").

275. See CowaN, supra note 266 , at 104-05 ("The honeymoon is one nightly repetition of legalized prostitution, sinking the pure, high and holy into the low, debasing and animal.... [T] result of marital excess is as disastrous to the body, mind and soul of the individual as is unlegalized prostitution."); Alice B. STOCKhaM, TOKOLOGY, A BOOK FOR Every WOMAN 154 (Chicago, Alice B. Stockham \& Co. rev. ed. 1889) ("Is it too strong language to say [a wife] is the one prostitute taking the place, for the man, of many, and not like her, having choice of time or conditions? In consequence she not only suffers physically, but feels disgraced and outraged to the depths of her soul."); B.O. Flower, Prostitution Within the Marriage Bond, 13 ARENA 59, 70 (1895) ("[P]rostitution, even though sanctioned by the church and state in the marriage ceremony, is none the less prostitution, and ... its fruits are altogether debasing.").

276. See supra text accompanying notes 184-209, 261-264.

277. DUFFE, supra note 266 , at 207.

278. Flower, supra note 275 , at 70.

279. STALL, supra note 268 , at 93 (citation and internal quotation marks omitted). How could it be a wife's duty, Henry Clarke Wright similarly asked, "to submit to snch a relation, when her own soul not only does not sanction, but loathes it! . . A duty to become a prostitute, -a mere tool of her husband's gratification! It is a horrid mockery!" WRIGHT, supra note 274, at 39-40. 
its male perpetrator. It also indicated that the physiological injury that marital rape inflicted on women and the children they unwillingly bore inevitably redounded to men's material, emotional, and dynastic detriment as husbands and fathers. Nineteenth-century feminists, demanding a woman's enforceable right to her own person, focused on the injury that marital rape caused women. Prescriptive writers, hoping to appeal to the self-interest of husbands, explained the physiology of marital rape in much more male-centered terms than those feminists employed, ${ }^{280}$ using their own health claims to establish their own (male-centered) case for voluntary restraint.

In contending that husbands put their own health at risk when they subjected their unwilling wives to marital intercourse, prescriptive writers built on a widespread understanding that a man could endanger his prospects by expending sexual energy. Many articulate Americans in the nineteenth century envisioned the male body as a closed energy system and sexual activity as a taxing drain, so that the outlay of sexual effort would leave a man physically weakened and with less vigor to devote to intellectual, economic, and moral pursuits. This presupposition was endorsed by leading medical professionals ${ }^{281}$ popular guides to men's health, ${ }^{282}$ and even some of the utopian experimental communities of the day, whicl taught their male followers to avoid sexual climax. ${ }^{283}$

280. See supra text accompanying notes 227-234.

281. See, e.g., Benjamin Rush, MEdical INQuiries and ObSERVATIONS UPON THE Diseases of THE Mind 347 (Hafner Publishing Co. 1962) (1812) (warning that sexual appetite, "when excessive, becomes a disease both of the body and mind," with potential consequences including "seminal weakness, impotence, dysury, tabes dorsalis, pulmonary consumption, dyspepsia, dimness of sight, vertigo, epilepsy, hypochondriasis, loss of memory, manalgia, fatuity, and death"); W., Remarks on Masturbation, 12 Boston MEd. \& Surgical J. 94, 96 (1835) ("[This drain upon the system [ejaculation] should . . . be made but sparingly. Sturdy manhood, in all its vigor, loses its energy and bends under the too frequent expenditure of this important secretion; and no age or condition will protect a man from the danger of unlimited indulgence, [even if] legally and naturally exercised."); Gail Pat Parsons, Equal Treatment for All: American Medical Remedies for Male Sexual Problems: 1850-1900, 32 J. Hist. MED. \& Allied Sc1. 55, 59 (1977) ("Doctors believed that the healthy body, whether male or female, maintained an equitable distribution of this static quantity of nerve force. ... Too much sexual excitement ... could upset a delicate health sustaining equilibrium. Excessive sexual activity attracted this force to the genitals and withdrew it from other areas of the body ....").

282. For some of the more extreme manifestations of this argument, see SYLVESTER GrAHAM, A Lecture to Young Men 20 (Arno Press 1974) (1834) (warning that sexual "excesses" will "produce the most terrible effects. The nervous system ... is tortured into a shocking state of debility ... and the muscles generally, become relaxed and flaccid; and consequently, all the organs and vessels of the body, even to the smallest capillaries, become extremely debilitated; and their functional power, exceedingly feeble."); HenRy G. Hanchett, Sexual Health 25-26 (New York, Charles T. Hurlburt 1887) ("The sexual act is an exhausting one. It takes hold of the whole body, and demands the best energies of every part of the system. It requires so much of nerve-force that it ought always to be followed by a period of rest."); Frederick Hollick, A Popular Treatise on Venereal Diseases, IN All Their Forms 361 (New York, Excelsior Publishing House 50th ed. 1881) ("When a man expends too much Semen ... he does the same thing as if he really destroyed a portion of his brain, because he takes away that which is necessary to nutrify it. Nature will not produce enough of these 
The prescriptive literature on marriage contained analogous warnings about the still more severe physiological consequences for men who had marital intercourse without their wives' consent. Dr. Cowan issued one of the most complete accounts of the potential dangers. "[I]f the husband demands his rights from the wife, who only accedes through dread of consequences," he warned, "the effect on the man's brain and nervous system is very little different from that produced by self-abuse." 284 Indeed, Cowan elaborated a progression of symptoms with starkly debilitative consequences: "a general weakness of the nervous system;" the "inability to promptly digest ordinary food;" "a weakening of the joints, and especially the joints of the knees, a softening of the muscles, a want of strength, and a motion of an unsteady, dragging nature, differing so noticeably from the springing, strong, elastic carriage of the continent individual;" "dyspepsia;" "general debility;" "consumption;" "weakened and impaired" memory; "disordered vision;" "impaired" hearing; and "[p]aralysis of the lower extremities." 285 Henry Clarke Wright went so far

substances to make Brain and to allow of licentious indulgence at the same time."); see also G.J. Barker-Benfield, The Horrors of the Half-Known life: Male Attitudes Toward Women and Sexuality in Nineteenth-Century America 180-88 (1976); Stephen Nissenbaum, Sex, Diet, and Debility in Jacksonian America: Sylvester Graham and Health Reform 25-38 (1980); Jayme A. Sokolow, Eros and Modernization: Sylvester Graham, Health Reform, aNd the Origins of Victorian Sexuality in AMERICA 12-14, 77-99 (1983); Ronald G. Walters, Primers for Prudery: Sexual Advice to Victorian America 32-48 (1974); Ben Barker-Benfield, The Spermatic Econony: A Nineteenth-Century View of Sexuality, in The AMERICan Family iN Social-Historical Perspective 336, 340-44 (Michael Gordon ed., 1973).

283. Most notably, a utopian community in Oneida, New York practiced "male continence," sexual intercourse without male orgasm or ejaculation, under the leadership of John Humphrey Noyes. Noyes argued that the habit would "give new speed to the advance of civilization and refinement. The self-control, retention of life, and ascent out of sensualism, which must result from making freedom of love a bounty on the chastening of physical indulgence," would, he promised, "raise the race to new vigor and beauty, moral and physical." John Humphrey Noyes, Male Continence 16 (Oneida, Office of Oneida Circular 1872), reprinted in The Berean, Male Continence, Essay on Scientific Propagation (Amo Press 1969); see also Lawrence Foster, Religion and Sexuality: Three American Communal Experiments of the Nineteenth Century 74, $93-98$ (1981); LaWrence Foster, Women, Family, and Utopia: Communal Experiments of the ShaKers, the ONeIDa Community, AND the Mormons 81-84 (1991); Louis J. KERN, AN ORdered Love: Sex Roles and

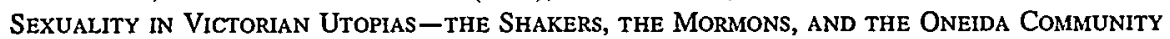
224-44 (1981); Spencer Klaw, Without Sin: The Life and Death of the ONEida Community 130-32 (1993); Ira L. Mandelker, Religion, Society, and Utopia in Nineteenth-Century AMERICA 36-37, 118-19 (1984).

The Shaker community, which practiced complete abstinence, similarly believed that sexual expenditure "taxe[d] severely every part of the vital economy" of the body. "[U]nchastity causes in the aggregate, a tremendously expensive, inane and profitless drain upon the vital forces," Shakers explained. "It penetrates every part of the system and drains therefrom the finest essence of brain and blood and nerve, the secds of health, vigor, life and motion, and expels them as food for demons of darkness that feed on the vices of mortals." A.G. Hollister, Mission of Alethian Believers, Called Shakers 7 (Mount Lebanon, A.G. Hollister 1892-1899); see also KERN, supra, at 77-91.

284. CowAN, supra note 266 , at 105.

285. Id. at 105-06. George Napheys similarly observed that: 
as to suggest that "[i]ntemperance, war, slavery, unsuitable food, dress and habitations, exposures to heat, cold, and excessive toil" had historically been less dangerous to the health of the male population than "uncalled for and unwarranted" marital intercourse. ${ }^{286}$ Duffey made the intent of such health advisories perfectly explicit. Even if a husband was too much of a "sensualist" to consider moral arguments or the interests of anyone but himself, the consequences for a man's own health"diminished strength, dimimished nervous force, and diminished mental powers"-were "sufficiently serious for men to pause, at least, in their selfish course, and consider a little."287

The prescriptive literature also described the marital disfunction, financial strain, and household disorder that would come to pass if wives were physiologically damaged by unwanted marital intercourse, explaining women's welfare in terms of their husband's self-interest. These tracts reported that undesired intercourse was devastating to a woman's health, even putting aside the risks involved in gestation and childbirth. Augustus Gardner, for instance, advised men that just one night of excess could have lasting consequences. Unless a wife retained control over her person on her wedding night, "permanent disorganizations," "uterine weakness with its whole train of nervous sympathies," were likely. ${ }^{288}$

Here again, the marriage manuals relied on a wider medical and prescriptive discourse, one that located women's physical and psychological vulnerability in their reproductive and sexual capacity. Most notably, doctors in the latter half of the mineteenth century were preoccupied by the mcreasing number of middle-class, urban women stricken with "hysteria,"

The ordinary results of an abuse of the conjugal privilege are, in the man, very much the same as those brought on by self-abuse. Locally there is over-excitation, irritability, and possibly inflammation. The digestion becomes impaired, dyspepsia sets in, the strength is diminished, the heart has spells of palpitation, the spirits are depressed, spermatorrhœa may arise, the genetic powers lose their vigor, there is unusual sensitiveness to heat and cold, sleep is not refreshing, and a jaded, languid indifference takes the place of energy and ambition.

George H. Napheys, The Transmission of Life: Counsels on the Nature and Hygiene of the Masculine Function 179-80 (Philadelphia, H.C. Watts \& Co. new ed. 1884).

286. Henry C. Wright, Marriage and Parentage: OR, the Reproductive Element in Man, as a Means to His Elevation and Happiness 172 (Boston, Bela Marsh 1854); see also Augustus K. Gardner, Conjugal Sins Against the Laws of Life and Health 78 (New York, Hurst \& Co. rev. ed. 1874) ("Excess in lawful desire is subject to the same corporeal laws as in unlawful, and its penalty is disease and debility."); WILLIAM GOODELL, LESSONS IN GYNECOLOGY 43637 (Philadelphia, D.G. Brinton 1880) ("Destroy the reciprocity of the union, and .... Nature exacts a forfeit .... [W]itness [the husband's] ill health and ill temper ...."); STALL, supra note 268, at 130 (predicting a "destruction of physical power" and "weakening of the intellect," which would leave the husband "unfit for study, mental activity, and oftentimes for all kinds of business").

287. DUFFEY, supra note 266, at 220-21.

288. GARDNER, supra note 286 , at 79. "So serious was the hæmorrhage" resulting from one husband's initial use of force, Gardner wrote, "that the services of several of the most eminent surgeons of this city were requisite, and the life of the blooming bride was for several days most seriously jeoparded." Id. at 77. 
a newly discovered medical condition that manifested itself in pain, paralysis, chronic fatigue, and general "nervousness."289 Medical science could discover no organic basis for hysteria, but physicians speculated that its predominance reflected an emotional instability and physical weakness inherent in women's nature. ${ }^{290}$ Many doctors thought, more specifically, that the onset of hysteria was linked to a woman's reproductive cycle and that women with a history of sexual excess were far more likely to fall victim to the disease. ${ }^{291}$ Notwithstanding such insights, physicians could devise no reliable cure for hysteria; the victims' families were often faced with medical bills of mounting size and disruptions of imdeterminate length. ${ }^{292}$

The prescriptive literature's description of what happened to wives subjected to unwanted marital intercourse, which included both verifiable somatic ailments and reports of the sort of "nervous weakness" associated with hysteria, resonated with widespread popular awareness of the hysteria phenomenon. According to these popular experts on marriage, husbands-perhaps without even realizing it-were making their wives pathologically "weak and nervous" and imposing upon themselves "large financial outlays for medical advice and attendance." 293 Whenever a husband did not permit his wife to regulate their marital intercourse, the woman's "tender, delicate organs of generation" were prone to "become inflamed, and ulcerate, and render the woman an invalid."294 "[D]ireful diseases, insanity and consumption"" were the usual result. ${ }^{295}$ Stated most bluntly, these experts warned that husbands intent on claiming their "legal

289. See SMith-Rosenberg, supra note 227, at 204-05; Barbara J. Berg, The Remembered Gate: Origins of AMERICAN Feminism, THE Woman AND the City, 1800-1860, at 112-14, 116-19 (1978); Barbara Ehrenreich \& Deirdre English, For Her OWn Good: 150 Years of the Experts' Advice to Women 103-05 (1978); Rachel P. Maines, The Technology of ORGASM: "Hysteria," the VibRator, and WOMEN's SeXual Satisfaction 4-5, 7-8, 35 (1999); Ann Douglas Wood, "The Fashionable Diseases": Women's Complaints and Their Treatment in Nineteenth-Century America, 4 J. INTERDISC. HIST. 25, 26-29 (1973).

290. See SMITH-Rosenberg, supra note 227, at 204-06; EHRENREich \& ENGLISH, supra note 289, at $110-11$.

291. See SMIth-Rosenberg, supra note 227, at 206-07; BERG, supra note 289, at 114-15; EhrENREICH \& ENGLISH, supra note 289, at 110-11, 134; MAINEs, supra note 289, at 36, 38, 41; Wood, supra note 289 , at 28-29, 36 .

292. Indeed, Carroll Smith-Rosenberg has suggested that women may have become hysterics precisely because it became a socially acceptable way in which they could deviate from routine responsibilities that had proven deeply unsatisfying. See SMITH-ROSENBERG, supra note 227, at 207-08; see also BERG, supra note 289, at 116, 120; EHRENREICH \& ENGLISH, supra note 289, at 107-08, 13340; Wood, supra note 289, at 35-36. Rachel Maines has offered a somewhat narrower explanation, positing that the victims of hysteria may have been expressing a dissatisfaction and frustration that was particularly sexual and somatic in nature. See MAINES, supra note 289, at 5 ("When marital sex was unsatisfying and masturbation discouraged or forbidden, female sexuality, I suggest, asserted itself through one of the few acceptable outlets: the symptoms of the hysteroneurasthenic disorders.").

293. Stall, supra note 268 , at 131.

294. DuFFEY, supra note 266 , at 215.

295. Id. at 216 (quoting Dr. Dixon). 
right" were "destroy[ing] and oft-times murder[ing] their wives" and, with them, their marriages. ${ }^{296}$

The physiological dangers confronting the children that these wives unwillingly conceived were hardly less severe. In this context, too, the prescriptive literature advised husbands that they would ultimately bear the cost of the injury they inflicted through marital rape, in this case through a diminution in the quality of their offspring. Like the leaders of the woman's rights movement, ${ }^{297}$ prescriptive writers in the latter half of the nineteenth century contended that acquired characteristics were inheritable. This meant that a wife's despair about her pregnancy would be forever stamped on her-and her husband's-child. Wright warned that when a wife became "a mother from necessity rather than from choice," her child would "partake of her degradation." ${ }^{298}$ "[D]eveloped in joyless, lifeless imbecility, or intense anguish," it would be "born an idiot, or without sufficient vital force to develop it into life with the ordinary energies and faculties of a man or woman. ${ }^{.299}$ The child would also be permanently marked by his father's base carnality in forcing marital

296. CowAN, supra note 266, at 311; see also GoodeLL, supra note 286, at 437 (explaining that unwanted marital intercourse reduced a wife to a "wreck of body and of mind"); TRALL, supra note 269 , at 244 (reporting that "[m]any a man who would have becn a good husband if he had only known how" had "destroyed [his wife'sl health, happiness and life" by denying her control over marital intercourse).

Marriage manuals often warned husbands that their wives' health was particularly impaired by sexual intercourse during pregnancy or lactation. See [William A. Alcott], The Physiology of MARriage 158 (Boston, John P. Jewett \& Co. I856) ("[I]f young men as a gencral rule, could see... all the diseases of mind and body to which, by their sensual indulgence during pregnancy, they subject their wives and children, they would hesitate in their career of thoughtlessness and recklessness."); STALL, supra note 268, at 215 ("[T]he conscquences [of sex during pregnancy] have entailed permanent injuries upon the young wife, and oftentimes resulted in death itself."); STOCKHAM, supra note 275 , at $159-60$ ("The sexual relation at this time [during gestation] exhausts the mother .... It is worth investigating, whether the cause of much of the pain at parturition may not also be removcd by the practice of continence during gestation.") (internal quotation marks omitted); WRIGHT, supra note 286 , at 217 ("[Sex during pregnancy] deranges the action of the whole generative system; the pains and perils of childbirth are greatly aggravated, and the life of child and mother is oftentimes endangered."); Boyd, supra note 266, at 319 ("To prostitute her while pregnant to merely sensual uses inflicts atrocious wrongs both on her and on her offspring. (It causes the woman a variety of distressing maladies .... . The same holds true in a measure so long as the infant draws its mother's milk.)").

297. See supra text accompanying notes 23I-234.

298. Wright, supra note 274 , at 116.

299. Id. at 40; see also CowAN, supra note 266, at 131-32 ("The originating of children in God's own image should be an intensely active, loving desire on the part of both man and wife. ... Children can as easily be brought into the world with happy, sunny, laughing natures, as with cross, fretful, irritable natures."); HAYES, supra note 217, at 54 ("The children born of such enforced embraces are, in the language of Michelet, an outrage on their mothers."); TRALL, supra note 269, at xii ("[The] mental states ... of both parents at the moment of conception, affect the future being for life ... [The mother's] happy or unhappy circumstances, through the periods of gestation and lactation, continually affect and modify the organization of the offspring for good or for evil."); Flower, stpra note 275, at 70 ("When a woman is forced to bear ehildren to a man she hates or no longer loves, ... the child is cursed before it is born. ... I can conceive of few crimes greater than the bringing into the world of children of lust or hate."). 
intercourse. "Witness," Cowan observed, the thousands of children born predisposed to be "the idiotic, the weak, the diseased, the drunkards, the gluttons, the debased." ${ }^{300}$ These children, Alice Stockham elaborated, were endowed before birth "with lustful passions and morbid appetites."301 Benjamin Flower similarly concluded that the "children of lust," born to women whose husbands refused to recognize their "rights and desires," could never rise much above the manifest qualities of their fathers; they were destined to fill "prisons and insane asylunıs."302

\section{Manly Self-Restraint and Self-Interest}

The inarriage nianuals and health guides of the second half of the nineteenth century offered an extensive account of the injury that marital rape inflicted, on husbands along with their wives and children. But this literature did not proceed to advocate legal reform. Unlike the mineteenthcentury feminist movenent, it accepted a husband's right to determine the terms of sex in marriage. The prescriptive literature described the harm that marital rape caused in order to set the stage for the presentation of strategies designed to encourage husbands to refrain voluntarily from exercising their admitted legal prerogatives. Having recognized a husband's sexual entitlement, these strategies appealed to a inan's self-interest explicitly and without apology. Prescriptive writers acknowledged that a husband's conjugal restraint would benefit his wife, but hastened to reassure their inale readers that voluntarily ceding control over niarital intercourse would always strengthen and solidify a husband's power and position in his family. Their argunients for voluntary restraint were directed at a man's self-esteem and his property interest in his wife's welfare. Storer, the leader of the anti-abortion movement, offered the quintessential explanation for his recommendation that husbands no longer subject their wives to unwanted intercourse, characterizing a wife's iniproved health and longevity solely as an aspect of her husband's wellbeing:

And here let me say, that I intend taking no ultra ground; that I am neither a fanatic nor professed philanthrope; and that in loosing, as I hope to do, sonie of woman's present chains, it is solely for professional purposes, to increase her health, prolong her life, extend the benefits she confers upon society-in a word, selfishly to enhance her value to ourselves. ${ }^{303}$

300. Cowan, supra note 266 , at 138.

301. Sтоскнам, supra note 275 , at 154.

302. Flower, supra note 275 , at 67.

303. Horatio Robinson Storer, Is It I?: A Book For Every MAN 89 (Boston, Lee \& Shepard 1868). 
Much of the prescriptive literature evoked similar themes, albeit in somewhat less blatant and extreme form.

A number of writers proposed that a husband think of voluntarily ceding control over intercourse to his wife as the best possible manifestation of manlimess, a way to confirm and display his noble character. This was a particularly powerful approach because it connected to an enormous body of existing sentiment which insisted that the key characteristic of successful masculinity was self-restraint in the face of strong temptation. The contention was especially prominent in discussions of male sexuality, which simultaneously recognized the fierce sexual desires of young men and urged them to direct their energy to matters intellectual and econoinic instead. ${ }^{304}$ Reformers in other arenas, however, also profitably relied on the prevalent association between ideal masculinity and self-restraint. Activists seeking to change white America's initially cavalier attitude toward the lynching of African-American men in the South, for instance, effectively depicted lynch mobs as lustful, passionate, undisciplined, and accordingly unmanly. ${ }^{305}$

In the latter half of the nineteenth century, prescriptive writers brought the weight of this understanding of masculinity to bear on the question of forced sex in marriage. Boyd emphasized that "it is for woman to determine when (and when only) the closest relations may be assumed," by reminding husbands that "[i]t is the part of a true man to render instinct and desire wholly subject to reason and conscience." ${ }^{306} \mathrm{ln}$ deed, he compared a husband's sexual desire to a formidable racehorse that needed to be broken by masculine human will. "If a mettlesome young blood-horse becomes your property, do you let him tame you and drive you?," Boyd asked. If a husband did, "such failure would betray weakness and lack of manhood. Just so with regard to the amative propensity; you are to get the upperhand and keep it. Your manliness is shown when you possess yourself and master passion, not when passion overpowers and possesses you." ${ }^{307}$ Duffey seconded the idea that "true manliness" in a husband entailed "a wise restraint of the passions for his

304. See supra notes 281-283 and accompanying text; see also NoYes, supra note 283, at 20 ("Male Continence in its essence is self-control, and that is a virtue of universal importance.").

305. See GaIl Bederman, "The White Man's Civilization on Trial": Ida B. Wells, Representations of Lynching, and Northern Middle-Class Manhood, in MANLINESS \& Civilization: A Cultural History of Gender and Race in the United States, 1880-1917, at 45, 58-59 (1995) ("[Ida B.] Wells [a leading anti-lynching activistl depicted lynch mobs as vile, unmanly and cowardly, hiding their own rampant lusts with sanctimonious calls for chastity, and excusing their brutal murders by invoking the honor of harlots.... Northern men could only regain their manliness by ending lynching."); see also id. at 70 (concluding that Wells's campaign "force[d] some long-lasting, if subtle, shifts in whites' approaches to lynch law.... After 1894, most Northern periodicals stopped treating lynehing as a colorful Southern folkway.... It became a truism that lynching hurt America in the eyes of the 'civilized world."').

306. Boyd, supra note 266, at 319.

307. Id. 
wife's sake."303 As Wright also explained, "[h]uman law and custom" gave the husband complete authority over marital intercourse, but a man who was "pure, honest, noble, manly" would never "demand[] sensual gratification, against the wishes of his wife."309

Many authors also counseled husbands that ceding control over marital intercourse was the only way to preserve the enormous personal benefits of marital love, happiness, and harmony. "The first great requirement necessary in those whose desire is for a happy and lovable married life," Cowan advised, was that it "be allowed by the liusband that with the wife should rest the question as to the time when she wished to accept the sacred trust of maternity." ${ }^{310}$ Where a wife was reduced to "loathing submission," William Goodell agreed, "love and affection change[d] into aversion and hate. ${ }^{1311}$ McLaury took pains to make clear to husbands that exercising their marital rights would simply produce "morose, angular, and disagreeable" wives; "peaceful rest" only blessed marriages in which the husband allowed his wife to determine the terms of marital intercourse. ${ }^{312}$

On a related note, the prescriptive literature promised husbands that their voluntary restraint would ultimately lead to more pleasurable marital intercourse, making a husband's self-interest in his wife's welfare clearer still. Duffey predicted that a husband who continued to court his wife's affection after marriage and wait for reciprocation would find "greater delight" in a "monthly inarital conjunction" than a selfish sensualist could obtain from "daily or semi-weekly excesses." ${ }^{313}$ A husband, she wrote, "will have only himself to blame, if he is bound all his life to an apathetic, irresponsive wife. ${ }^{314}$ Cowan, a less elegant if more direct writer, surmised that "nearly all women ... who are used by their husbands simply as chattels ... lie passive and motionless." "As to the possible pleasure to him of such a union," Cowan suggested that a husband "might as well

308. DUFFEY, supra note 266 , at 284.

309. WRIGHT, supra note 286, at 184, 182 (emphasis added); see also J.H. KellogG, PLAIN FACTS FOR OLD AND YouNG 264-65 (Burlington, I.F. Segner 1884) ("The duty of the husband [to restrain himself] is very plain, and to him the wise physician will appeal in a manner which cannot fail to arouse him to a sense of his duty if there is yet left unconsumed by the fires of lust even a vestige of genuine manhood."); STALL, supra note 268, at 102 ("[T] he man who gains the mastery [of his sexual nature] grows more manly, more noble, while the man who is overcome becomes less manly, and if lust be given the sway he becomes increasingly beastly.").

310. CowaN, supra note 266, at 394.

311. GoodeLL, supra note 286 , at $436-37$.

312. McLaury, supra note 271, at 161. Wright, too, spoke again to instruct husbands that they should "ask not what the law allow[ed]," but "govern themselves by the one only law of the heart." WRIGHT, supra note 286 , at 139 . If a husband loved his wife and wanted to keep her love, he could "never, intentionally nor unintentionally, impart to her the germ of a new existence, till she demands it, and is ready, cheerfully and joyfully, to receive, nourish and develop it." Id. at 184.

313. DUFFeY, supra note 266 , at 223.

314. Id. at 206. 
practice solitary indulgence." ${ }^{315}$ Stall agreed that a man's exercise of his marital rights would always be self-defeating in sexual terms. It would only render his wife "incapable of marital pleasure, and also render[] her mcapable of bringing to him the satisfaction which he seeks." ${ }^{316}$

Even outside the woman's rights movement and the domain of the free lovers, the question of marital rape was hardly unthinkable or unspeakable in the latter half of the nineteenth century. The popular prescriptive literature agreed with feminists, publicly and at length, that marital rape inflicted severe harm. But feminists made a rights claim putting forth women's interests, as distinct from and defined against the interests of men. They wanted a wife to have the legal right and socioeconomic ability to refuse her husband's sexual demands against his will, recognizing that voluntary concessions were an unreliable defense against potentially recalcitrant, dangerous, and selfish husbands. The popular prescriptive literature, in contrast, did not situate its opposition to marital rape im an analysis of women's subordination, and did not support giving women enforceable rights against men. It left decisive control over marital intercourse in the husband's hands, to be exercised in his own interest as he saw fit. Popular prescriptive writers promised that the interests of husband and wife coincided on the issue of marital rape (although one could deduce from their descriptions of contemporaneous marital relations that many husbands had been slow to recognize that fact). The prescriptive account of the injury that marital rape produced focused as much attention on the costs to husbands as wives. Yet it was clear which party to the marriage would prevail when marital mutuality broke down.

IV

\section{Circumscribed Legal Reform in the Nineteenth Century: The LAW OF DIVORCE}

In the end, authoritative legal sources in the latter half of the nineteenth century refused to alter the law's treatment of marital rape, with the exception of marginal changes in the terms on which divorce was available. The fate of the feminist campaign for a woman's right to her own person reveals a deep reluctance to tamper with a husband's conjugal

315. CoWAN, supra note 266, at 111; see also HAYES, supra note 217 , at 54 ("[W1here the woman is enforced to yield to her husband's lust, coition then becomes purely animal on the part of the husband, and he might as well gratify himself upon a stuffed figure.").

316. STALL, supra note 268, at 130-31; see also FoWLER, supra note 271, at 684 ("OBLIGING HER to submit, against her inelinations, prevents your enjoyment and disgusts her of you, infuriates you against her, diseases her, and thus cuts off your own and her future sexual pleasures, and outrages Nature's sexual ordinances."); STOCKHAM, supra note 275 , at 156 (describing a married couple in which "a single [voluntary] coition in a month gave the husband more satisfaction than the many had done previousiy"); WRIGHT, supra note 286, at 191 ("Manly passion is not in itself repulsive or unweicome to the purest heart of woman, when it is the voice, as it ever should be, of a love unspeakable."). 
prerogatives, in an era when lawmakers were willing to ameliorate the property rights of married women and, eventually, to ratify woman suffrage. Social recognition of the proposition that marital rape inflicted severe harm on women was widely disseminated. But in this context where marital intercourse and reproduction were so manifestly at stake, legal authorities-like popular prescriptive writers-were strongly disinclined to incorporate into the law a recognition of marriage as a possible site of antagonism and danger, in which women might need and merit enforceable legal rights protectimg them from their husbands. ${ }^{317}$

Authoritative legal sources considering marital rape in the last decades of the nineteenth century were only willing to make limited adjustments at the peripheries of the divorce regime. Over time, in some jurisdictions and in some extreme circumstances, it became easier for a (privileged) woman to secure a divorce based on her husband's unwanted sexual demands, or to prevent her husband from divorcing her because she refused marital intercourse. These changes took feminists' concerns into account, but in a severely modified form.

\section{A. A Husband's Unwanted Sexual Demands as Legal Cruelty}

The first site of change in the law's treatment of marital rape in the nineteenth century revolved around the question of whether, and when, a husband's unwanted sexual demands might constitute legal cruelty entitling his wife to divorce. This was a significant issue because divorce in the nineteenth century was available only for cause, and the recognized grounds of fault were highly limited, the most important being adultery, desertion, and cruelty. ${ }^{318}$ In the first half of the nineteenth century, courts were almost completely silent on the question of whether marital rape could ever be cruelty. The one notable case on the subject during this period, Shaw v. Shaw, ${ }^{319}$ suggested that wives would encounter extreme difficulty in establishing the claim.

Emeline Shaw's petition for a divorce on the ground of intolerable cruelty reached the Connecticut Supreme Court of Errors in 1845. Mrs. Shaw needed to avoid sexual intercourse for clear and undisputed health reasons, which the court acknowledged. But her husband, Daniel Shaw, had repeatedly and forcibly compelled her to submit, despite her protests

317. The strength with which legal authorities clung to a husband's right of sexual access, even as they accommodated some expansion of women's economic and political rights, might be read as support for Catharine MacKinnon's argument that sex-based domination takes its deepest and most fundamental form in control over sexuality. MacKinnon contends that "[s]exuality," rather than property or politics, "is the social process through which social relations of gender are created, organized, expressed, and directed." MACKINNON, TowARD, supra note 8, at 3.

318. See supra text accompanying notes 35-36.

319. 17 Conn. 189 (1845). 
and attempts to escape ${ }^{320}$ The supreme court of errors agreed with Mrs. Shaw that involuntary marital intercourse might constitute cruelty in cases where the wife had physiological grounds for refusal. Yet it denied her a divorce, on the theory that there was insufficient evidence that her husband had known the state of her health and understood the consequences of his behavior. Mrs. Shaw, the court admitted, had told her husband that his sexual demands endangered her health. But she could not prove, the court reasoned, that he believed her. ${ }^{321}$ In coming to this judgment, the court focused on the "frailty" of Mr. Shaw, rather than his wife, and made its deep reluctance to reorder the marital relation clear. The court contended that the law had to allow a husband room for irrationality and willful blindness when his marital prerogatives were at stake. "Are we," the court asked, "to allow nothing to the frailty of human nature, excited by passion?"322 The court thought not and invoked the language of privacy: "In a case of so delicate a nature, the court ought not to interfere, but for the most substantial reason." ${ }^{323}$ This line of argument placed no weight on the injuries that Mrs. Shaw had already suffered and the high likelihood that Mr. Shaw would subject his wife to forced sex again if she had to return to his household. Although the trial court had found that Mrs. Shaw "had just reason to fear, that he would compel her to occupy the same bed with him regardless of the consequences to her health," the supreme court of errors considered this possibility "too contingent, and too remote, to lay a foundation for the action of this court." 324

Within less than a decade, however, the Shaw decision was being criticized, even in legal treatises. As early as 1852, Joel Bishop, author of one of the leading family law treatises, concluded that Mr. Shaw had exercised his marital prerogatives "to a very questionable extent." ${ }^{\text {"25 }}$ Bishop noted, quite sharply, that the Connecticut court had not indicated how a husband "was to be made acquainted with the injurious tendency of his conduct, when he refused to inform himself after such warning [from his wife], or how a wife could ever protect herself from the devouring consequences of ungoverned lust, warring against her under the cover of marital right. ${ }^{326}$ Caroline Dall, a Massachusetts feminist who apparently learned of Shaw by reading Bishop's work, was more demanding. She argued in 1855 that the case constituted clear evidence in favor of eliminating a husband's marital prerogative, on the ground that voluntary restraint offered wives insufficient security: "In relation to such a right, it may be

320. See id. at 190-91, 195-96.

321. See id. at 195-96.

322. Id. at 196.

323. Id.

324. Id. at 196-97.

325. B1SHOP, supra note 32 , at 392.

326. Id. at 392-93 (emphasis added). 
said, that every thing will depend upon the character of the husband, and that no good man would feel himself justified by it. Precisely for this reason ought the law to be altered." "Have the law and the Courts," she wondered, "so little interest in the welfare of the State, that the personal degradation of the wife, which this law involves, is nothing to them?" ${ }^{327}$

The law of divorce for cruelty did soon move away from the position articulated in Shaw. By 1873, Bishop confidently reported "that the majority of our American judges would differ from the conclusion to which the majority of the Connecticut court arrived on these facts." ${ }^{328}$ Yet judges in the nineteenth century hardly adopted Dall's proposed reform.

In the last quarter of the nineteenth century, some courts found legally cognizable cruelty where a husband had subjected his wife to excessive sexual demands and those demands had endangered her health. Allowing these women to divorce their husbands was, it should be noted, a liberalization. Indeed, the decisions were part of a larger liberalization of divorce law in postbellum America, a period in which the number of divorces granted to women claiming cruelty escalated dramatically. ${ }^{329}$ These successful divorce suits for sexual cruelty suggest that the critique of marital rape articulated, in different forms, by feminists and popular prescriptive writers was influencing social understandings about appropriate marital behavior, at least in arenas otherwise receptive to change..$^{330}$

327. Dall, supra note 173, at 2. As Dall noted, the Connecticut Supreme Court of Errors had "refused to grant [Mrs. Shaw's] prayer, because the husband had no means of ascertaining that her health was injured, except,- her own assertion! Will it be believed," she asked, "that the Court neither required the husband to find such evidence for the future, nor instructed the injured wife as to some legal way of resisting such demands?" Id.

328. 1 Joel Prentiss Bishop, Commentaries on the Law of Marriage and Divorce 631 (Boston, Little, Brown, \& Co. 5th ed. 1873). Nonetheless, at least one decision rejecting a sexual cruelty claim in the last quarter of the nineteenth century cited Shaw with approval. In Youngs $v$. Youngs, 33 Ill. App. 223 (1889), an Illinois Appellate Court held that Marie Youngs's charge that her husband had compelled her "to submit to excessive sexual iutercourse" would "not amount to cruelty unless it is shown that it is persisted in by the husband against the will of the wife, and when he knows that the act is injurious to her bodily health," id. at 225 (citing Shaw). The Illinois Supreme Court also rejected Mrs. Youngs's sexual cruelty charge on appeal, noting only "that in our opinion it fails to show such state of facts as would amount in law to cruelty." Youngs v. Youngs, 22 N.E. 806, 808 (Ill. 1889).

329. See Robert L. Griswold, Law, Sex, Cruelty, and Divorce in Victorian America, I840-1900, 38 AM. Q. 721, 722 (1986) ("From 1867 to 1906, wives received 218,520 divorces because of cruelty and husbands 39,300. Next to nonsupport, cruelty cases rose more sharply than cases based on any other cause .... Comparing the years 1902-1906 with 1867-1871, divorces granted to wives on the ground of cruelty jumped 960 percent, and to husbands 1,610 percent.").

330. In analyzing some of the cases discussed in this section, Robert Griswold has argued that these decisions reflected and reinforced a growing understanding among male judges and male prescriptive writers that appropriate masculinity required large measures of self-restraint. See Robert $\mathrm{L}$. Griswold, Sexual Cruelty and the Case for Divorce in Victorian America, 11 SIGNS 529, 529-30, 532 34 (1986); Griswold, supra note 329, at 738-39; ROBERT L. Griswold, FAMILY AND DIVORCE IN CALIFORNIA, 1850-1890, at 114-16 (1982) [hereinafter GRISWOLD, FAMILY AND DIVORCE]. This social understanding, discussed above, certainly helps explain the courts' increasing willingness to grant women divorces for cruelty based on their husbands' excessive and unwanted sexual demands. See 
But the liberalization was strictly limited. First, the potential availability of divorce for cruelty did not change the law governing intact marriages. The legal possibility of exit may have given some wives more leverage in negotiating the terms of marital intercourse; yet it did not do more than that to protect wives from their husbands' sexual demands while the marriage lasted. Husbands retained their prerogatives without the threat of either criminal sanction or any other legal intervention. Until divorce, Hale's theory of irretractible consent remained in place.

Second, divorce was not an available or attractive option for wide segments of the female population in the nineteenth century. Pursuing a divorce petition for sexual cruelty was expensive and risky. Judicial recognition of cruelty could be explicitly class-conscious, with poorer wives expected to endure more. ${ }^{331}$ The public exposure involved in such a divorce suit might also be highly humiliating. As Dall observed, "women know that the coarsest woman [would have to] have suffered in no ordinary degree, before she could [be] driven into a public statement of such grievances. ${ }^{332}$ More fundamentally, many women, even if they could have successfully weathered a divorce suit, lacked real socioeconomic alternatives to marriage-a point feminist critics made abundantly clear. ${ }^{333}$ Women were likely to be particularly concerned about the well-being of their children and their ability to support them. Indeed, the economic vulnerability that most women and children experienced upon divorce led a number of mineteenth-century feminists to actively oppose the liberalization of divorce laws as a general matter. ${ }^{334}$ In addition, many women had

supra text accompanying notes 304-309. But Griswold does not discuss the feminist campaign against marital rape. Indeed, he suggests that feminists spoke about marital rape only amongst themselves and in private. See GRISwOLD, FAMILY AND DivorCE, supra, at 115 ("The right of women to say no to their husbands, early feminists confided privately, was at the heart of female emancipation."). In his account, the successful sexual cruelty cases are evidence of shared norms of companionate marriage, which evolved over time under men's stewardship. See id. at 119-21, 170, 173; Griswold, supra note 329, at 738-39. In fact, the feminist attack on marital rape was public and remarkably frank. It suggests that legal norms and social customs about marital conduct were radically more contested than Griswold posits and that they were importantly shapcd by women's advocacy as well as men's self-definition.

331. See infra text accompanying notes 358-373.

332. Dall, supra note 173 , at 2 .

333. See supra text accompanying notes 184-209, 261-264.

334. As Antoinette Brown Blackwell explained:

The advantage, if this theory of marriage [with liberalized divorce rules] is adopted, will not be on the side of woman, but altogether on the side of man. The cure for the evils that now exist is not in dissolving marriage, but it is in giving to the married woman her own natural independence and self-sovereignty, by which she can maintain herself.

Tenth National Woman's Rights Convention, supra note 144, at 728 (statement of Antoinette Brown Blackwell). Henry B. Blackwell (Antoinette's brother-in-law) agreed, contending that "indissoluble marriage or free divorce, marital fidelity or unbridled licentiousness, have literally nothing to do with" women's enfranchisement. "Since Free Love, as it is called, would be, practically, frcedom of unworthy men to leave their wives and children to starve, while it could not give similar freedom to mothers to leave their children, there is no danger that women will ever favor such a system." H.B.B., Woman Suffrage and Free Love, Woman's J. (Boston, Chicago, \& St. Louis), Sept. 12, 1874, at 294, 
profound religious or moral objections to divorce. Opposition to divorce remained widespread among American churches in the second half of the nineteenth century (especially in the absence of adultery). ${ }^{335}$ Even some members of the woman's rights movement argued that marriage vows represented an unseverable commitment. ${ }^{336}$

Third, the cruelty decisions accepting a husband's unwanted sexual behavior as ground for divorce only recognized harm in a confined category of cases. Under this case law, a wife could not secure a divorce simply because her husband had raped her. Marital rape, standing alone, was not a recognized cause for divorce. Instead, petitioming wives had to demonstrate: (a) that their husband's unwanted demands were unusual, either quantitatively excessive or particularly brutal; and (b) that these demands had jeopardized their health. It is to this third limitation that we turn first.

The leading cases where a wife subject to unwanted sexual demands won a divorce for cruelty all fit within a discernible, if narrow, pattern. In each case, the husband had acted in a manner that the court understood to be extraordinary. The jurisprudence described these men in the language of deviance. ${ }^{337}$ Some were very violent; they had acted "rashly and

294; see also Blatch, supra note 233, at 284 ("It is because divorce merely shifts the disease from one home to another, because it in no way lessens our trouble-the financial dependence of women, and enforced maternity-that the carrying of legislation upon the lines of easier dissolution of the marriage contract proves but a barren victory."); Clark, Matrimonial Bonds, supra note 138, at 47-48; DuBois, supra note 13 , at 843 .

335. For instance, the Catholic Church and all the major Protestant denominations were charter members of the National Divorce Reform League, an organization founded in 1885 to oppose liberalized divorce laws. See National Divorce Reform League, AN ABSTRact of Its ANNUAL REPORTS, OctoBER, 1885, at 1-2 (Montpelier, National Divorce Reform League 1885). One year earlier, the Methodist Episcopal Church had resolved "“[t]hat no divorce shall be recognized as lawful by the Church except for adultery." Journal of THE General CONFERENCE of THE METHodist Episcopal Church, Held in PhiladelPhia, PA., MAY 1-28, 1884, at 334 (Rev. David S. Monroe ed., New York, Phillips \& Hunt 1884). In 1883, the Presbyterian Church found "the action of the civil courts, and the divorce laws in many of the States" to be "in direct contravention of the law of God." 7 Minutes of the General Assembly of the Presbyterian Church in the United States of AMERICA 689 (New York, Presbyterian Board of Publication 1883).

336. Antoinette Brown Blackwell, for example, articulated one reason for her opposition to divorce this way:

Mrs. Stanton calls marriage a "tie." No, marriage is a relation .... Let, then, the two parties deliberately, voluntarily consent to enter into this relation. It is one which, from its very nature, must be permanent. Can the mother ever destroy the relation which exists between herself and her child? Can the father annul the relation which exists between himself and his child? Then, can the father and mother annul the relation which exists between themselves, the parents of the child? 1t can not be.

Tenth National Woman's Rights Convention, supra note 144, at 724 (statement of Antoinette Brown Blackwell).

337. I have not been able to find any American cruelty cases from the nineteenth century in which a wife sued for divorce because her husband had subjected her to forced sodomy. As nineteenthcentury American treatises noted, however, English precedent might have supported such a claim. See Bishop, supra note 32, at 382; WM. HARdCAstle Browne, A COMMENTARY on the LAW of DivorCE AND Alimony 112 (Philadelphia, Kay \& Brother 1890). In $N-v . N-$, decided by the English Court for Divorce and Matrimonial Causes in 1862, a wife sued for divorce on the ground of cruelty, 
roughly and unreasonably," 338 interested only in "the brutal gratification of [their] lustful passions." quency of their "incessant" demands. ${ }^{340}$ In each case, also, the conduct at issue had impaired the wife's health, or even "endanger[ed] her life by degrees."341 These opinions detailed afflictions that necessitated a woman's abstention from intercourse and made sex "painful and hurtful." 342 They involved marital relations where "a continuance of [the husband's behavior] would seriously and permanently injure [his wife's] health." 343 They described women who "had become weak, pale, nervous, spiritless and utterly broken down." ${ }^{344}$ In a number of cases, the husband

contending that her husband had forcibly sodomized her. See 3 Sw. \& Tr. 234, 234-36, 164 Eng. Rep. 1264,1264 (1862). The court indicated that forced sodomy could constitute cruelty, but held that a wife needed to present more than her own sworn testimony to prove the charge. See 3 Sw. \& Tr. at 238,164 Eng. Rep. at 1265 ("The crime here imputed is so heinous and so contrary to experience, that it would be most unreasonable to find a verdict of guilty where there is simply oath against oath, without any further evidence, direct or circumstantial, to support the charge.").

338. Mayhew v. Mayhew, 23 A. 966,967 (Conn. 1891) (quoting finding of trial court).

339. Melvin v. Melvin, 58 N.H. 569, 571 (1879); see also Walsh v. Walsh, 28 N.W. 718, 720 (Mich. 1886) (noting that Mr. Walsh had "used violent means to accomplish" sexual intercourse with his wife); Maget v. Maget, 85 Mo. App. 6, 8 (1900) ("[Lena Maget testified] that on one occasion when she declined to submit herself to the gratification of his insatiable lust he became very angry and struck her a violent blow on the back.").

340. Commonwealth v. Monroe, 9 Kulp 369, 369 (Pa. Ct. Quarter Sessions Luzerne County 1899); see also Grant v. Grant, 54 N.W. 1059, 1059 (Minn. 1893) (finding "that the defendant had continuously compelled the plaintiff to submit to excessive intercourse with him"); Fulmer v. Fulmer, 11 Ohio Dec. 795, 796 (Sup. Ct. Summit County 1884) ("Plaintiff showed by her physician also (a fact stated to him by defendant), that he had sexual intercourse with his wife not less than three times every might straight through."); Gardner v. Gardner, 58 S.W. 342, 342 (Tenn. 1900) (describing husband as “"a man of inordinate lust," who forced his wife to submit to "excessive indulgence").

341. Melvin, 58 N.H. at 571.

342. Walsh, 28 N.W. at 719.

343. Grant, 54 N.W. at 1059.

344. Fulmer, 11 Ohio Dec. at 796; see also Mayhew v. Mayhew, 23 A. 966, 967 (Conn. 1891) (reporting that trial court found "'injury to the plaintiff and to her health"" and "that the plaintiff could not safely cohabit with [her husband any] longer'"); Gibbs v. Gibbs, 18 Kan. 419, 424 (1877) (affirming trial court's judgment that husband was guilty of extreme cruelty, where husband had, inter alia, "compell[ed] his wife to sleep with him against her wishes, when she was diseased" in the womb, and wife's health had become "so bad that the physician who examined her, and testified at the trial, stated that he did not think she ever would be well"); Maget, $85 \mathrm{Mo}$. App. at 13 ("The acts complained of when not excessive and in ordinary circumstances were not per se unlawful, injurious or dangerous, but [they constitute cruelty] when carried to the excess shown by the evidence, with a knowledge on the part of defendant that such acts were injurious to the plaintiff's health and endangered it ....."); Gardner, 58 S.W. at 342 (noting that Mr. Gardner was accused of having "seriously impaired" the health of his wife, "a delieate woman").

In addition, the New Jersey Court of Chancery noted in Weigel v. Weigel, 47 A. 183 (N.J. Ch. 1900), that Alice Weigel would have established a divorce claim for cruelty, if she had been able to prove her allegation that her husband "violently and against [her] will, while she was sick and enfeebled, forcibly compelled her to submit to sexual intercourse, and that this conduct was so frequent and continued that it had caused [her] to have a number of miscarriages, and had undermined her health and endangered her reason," id. at 184. 
had communicated a venereal disease to his wife. ${ }^{345}$

These were extreme circumstances, already singled out by legal rule and social custom alike. The unrelenting physicality of the husbandly conduct at issue in the successful sexual cruelty cases resonated with the larger jurisprudence on divorce for cruelty, which began by recognizing only physical attacks that caused somatic harm and long continued to privilege physical over mental injury. ${ }^{346}$ The female plaintiffs in these cases, in turn, seemed to prove the veracity of the myriad warnings in the prescriptive literature about the physiological consequences of unwanted marital intercourse for women. ${ }^{347}$ Under these extreme circumstances, courts in the last quarter of the mineteenth century were willing to grant a wife's cruelty suit for divorce. Even the Connecticut Supreme Court of Errors upheld a cruelty-based divorce in 1891, in a case where the trial court had been careful enough to find that the husband actually "knew the condition of [his wife], and the suffering and injury [his "brutal and unendurable" conduct] would be likely to inflict on her, and her inability to safely and properly accede to his wishes." "348

These successful divorce suits marked an important change in the law's treatment of marital rape. They constituted, for the first time, some acknowledgment that a husband could "abuse[] his right to his wife's person" in a way the law would recognize. ${ }^{349}$ They prompted James Schouler, who had seen no need to mention a husband's marital prerogatives $\mathrm{m}$ the first two editions of his family law treatise (published in 1870 and 1874), to discuss the question in his third edition, published in 1882. Schouler had no doubt about the continued vitality of the criminal exeniption, but he carefully noted that "a husband who wantonly abuses his wife so as to inflict needless pain and injury upon her, and disregards her health and delicate organization, is guilty of legal cruelty." 350

The limits of this liberalization are easiest to discern in the unsuccessful cruelty suits that wives brought during approximately the same

345. See Morehouse v. Morehouse, 39 A. 516, 519 (Conn. 1898); Holthoefer v. Holthoefer, 11 N.W. 150, 150 (Mich. 1882); Canfield v. Canfield, 12 Mich. 519, 519 (1876); McMahen v. McMahen, 40 A. 795, 797-98 (Pa. 1898); see also BisHoP, supra note 32, at 380 ("A husband's attempts, when affected with venereal disease, to force his wife to his bed, is of a mixed nature, partly cruelty and partly evidence of adultery."); THE AMERICAN AND ENGLISH ENCYCLOPfDIA OF LAW, supra note 32, at 795; Browne, supra note 337, at 112-13; Henry Folsom PAGE, A ViEW of the LAW Relative to The Subject of Divorce, In OHIo, Indiana ANd Michigan 145 (Columbus, J.H. Riley \& Co. 1850).

346. See PAGE, supra note 345, at 138-41; Robert L. Griswold, The Evolution of the Doctrine of Mental Cruelty in Victorian American Divorce, 1790-1900, 20 J. Soc. HIST. 127, 127, 130, 135, 138 (1986); Griswold, supra note 329, at 729.

347. See supra text accompanying notes 288-296.

348. Mayhew, 23 A. at 967 (quoting finding of trial court).

349. BROWNE, supra note 337, at 112.

350. SCHOULER, supra note 30, at 63. For similar statements, see THE AMERICAN AND ENGLISH ENCYCLOPfDIA OF LAW, supra note 32, at 795; BROWNE, supra note 30, at 66; NELSON, supra note 32, at 328-30; Irving Browne, Oral Cruelty as a Ground of Divorce, 46 CENT. L.J. 81, 82 (1898). 
period. Consider Moores v. Moores, ${ }^{351}$ decided by the New Jersey Court of Chancery in 1863. Israel Moores had compelled his wife Mary to submit to marital intercourse, and she had become pregnant against her will. ${ }^{352}$ But unconsensual sex and unwilling maternity, by themselves, did not constitute the basis for a successful divorce suit for cruelty. Mrs. Moores lost because she could not demonstrate that the circumstances of her marriage were atypical. There was, the court found, "no pretence of any peculiar debility or physical infirmity on the part of the wife" and "no allegation of any violence" by the husband. ${ }^{353}$ The court observed, in particular, that "sickness" associated with pregnancy did not constitute physiological harm for purposes of establishing cruelty. ${ }^{354}$ Other failed divorce suits told the same story. Almost twenty years after Moores, in 1880, the Michigan Supreme Court denied Prudence Lockwood a divorce because she had not proved "that [her] illness was caused by her husband's conduct towards her, or that she was seriously ill at any time."335 Ida Louisa Dignan, sumg for divorce in 1896, alleged "roughness or violence in sexual intercourse." ${ }^{356}$ But the Supreme Court for New York County found no marital cruelty, reasoning that " $[t]$ he copulation itself was in the exercise of [her husband's] marital right, and it is not shown either that its ill consequences were due to any wanton brutality on his part, or of serious detriment to the plaintiff.",357

Even when a husband's behavior had been extraordinary and his wife's health endangered, a woman could still lose a divorce suit for cruelty. The courts hearing these claims, and the treatises discussing them, differentiated on the basis of class, so that they were more likely to see cruelty higher up the socioeconomic scale. In Walsh v. Walsh, ${ }^{358}$ which granted a divorce based on a husband's unwanted sexual demands, ${ }^{339}$ class signals were distributed throughout the opinion. The Supreme Court of Michigan took care to observe that the Walshes were comfortably welloff: They lived "in a fine house, well furnished, and provided with all the convemiences;" Mrs. Walsh "was furnished with elegant clothing, a horse and carriage." ${ }^{360}$ The court, moreover, found that Mr. Walsh had acted inappropriately in light of his social station. In reviewing letters that he had sent to his wife after she fled his household to escape his violent insistence on intercourse, the court determined that " $[t]$ hey are such as no man,

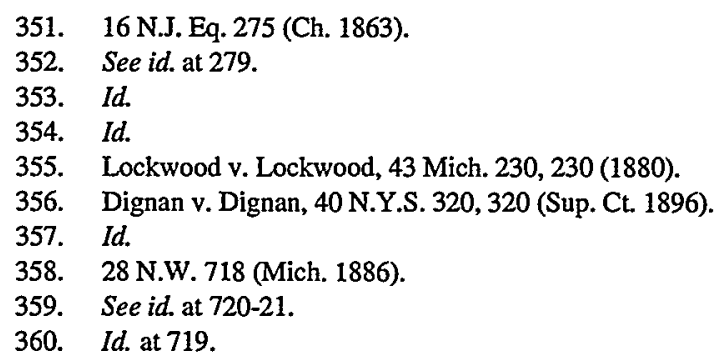


of any rank in life, could write to his wife, in his right senses, unless he was brutal and beastly in his nature."361

In English v. English, ${ }^{362}$ which denied a divorce petition for cruelty, the New Jersey Court of Errors and Appeals acknowledged that John English had subjected his wife Abby to brutal, dangerous, and unwanted sexual demands. As the trial court found, Abby English had suffered injuries in childbirth that made sex " agonizing[ly]" painful. ${ }^{363} \mathrm{Her}$ husband nonetheless insisted on intercourse virtually every night, "frequently even using force to accomplish his purpose. To her entreaties and expressions of apprehension that the intercourse would be fatal to her, he would reply, 'No fear of its killing you; you will not die until your time comes; you know how I am-I cannot control myself." 364 Moreover, John English's violence against his wife escalated over time. During their last encounter, he "struck her in the back with his fist" as she attempted to escape his bed, and "in holding her down [to the bed] he bruised her limbs so that they were lame and sore for more than two weeks afterwards."365

Although Abby English's claim certainly equaled the evidence in other, successful cruelty suits, the court of errors and appeals erected an additional barrier to divorce in this case. It rejected Abby English's petition on the ground that she had failed to establish that her husband would continue to subject her to forced sex if a divorce was denied. ${ }^{366} \mathrm{In}$ reaching this judgnient, the English court suggested, quite directly, that it was niore reasonable to expect Mrs. English to tolerate her husband's past conduct because the couple occupied a middling class status. Mr. English was a "tinsmith" and "comparatively unlearned," although he "had accumulated a moderate fortune." ${ }^{367}$ The court took this as evidence that his behavior should be interpreted as the carelessness of a simple man, rather than the product of any conscious bad intent. "The point for determination is not whether the husband, in his rudeness, has injured his wife without sufficient thought or care of her physical health, while doing an act which, in ordinary cases, is not unlawful, injurious or dangerous," the court explained. "[T]he true inquiry is whether the conduct of the husband has been such as to raise a reasonable apprehension that further acts of the same abuse will be committed if the wife should return to him. ${ }^{3368}$ Indeed, the court noted that Mrs. English might be making too much of the injuries she had suffered. Dr. Thomas, "a physician who ha[d] made women's

361. Id. at 720 (emphasis added).

362. 27 N.J. Eq. 579 (1876).

363. English v. English, 27 N.J. Eq. 71, 72 (Ch. 1876) (quoting Abby English).

364. Id.

365. Id. at $72-73$.

366. See English v. English, 27 N.J. Eq. 579, 585-86 (1876).

367. Id. at 583.

368. Id. at 585 (emphasis added). 
diseases a speciality," testified at trial that, "although there would be pain" whenever Mrs. English was subjected to intercourse, "a large proportion of married women assent under exactly those circumstances. ${ }^{1369}$ In predicting Mr. English's future conduct, the court relied heavily on his attempts at reconciliation after his wife left him. It evaluated these attempts very favorably, partially on the theory that they represented a greater effort precisely because Mr. English was "unlearned." Describing one letter that Mr. English sent to his wife, the court wrote: "He is not a scholar, but this letter is a most tender appeal to a wife, under any circumstances."370

The treatises were even more explicit about their understanding that cruelty claims were to be evaluated with class in mind. In explaining how a court should decide whether there was cruelty justifying divorce in any particular case, Schouler fiatly stated that "[t]he age, temperament, and disposition of the two spouses, and to some extent their rank and condition, ought fairly to be estimated."371 Bishop agreed: "“[W]hat may aggravate the character of ill-treatment," he reported, "'must be deduced from various considerations-in some degree from the station of the parties." "'372 The same conduct, in other words, might cause greater harm to a more refined woman. William Browne used the example of marital battery: "Between persons of education, refinement and delicacy, the slightest blow in anger might be cruelty, while between persons of a different character and walk in life, it might not mar to any great extent their conjugal relations, nor materially interfere with their happiness." ${ }^{\text {"373 }}$

The willingness of some courts in the last quarter of the nineteenth century to recognize a husband's unwanted sexual demands as legal cruelty meriting divorce was an important adjustment in the law's treatment of marital rape, and some evidence of growing social uneasiness about marital rape. But it was a very limited change: confined to the law of divorce, reserved for the most extreme circumstances, and class-sensitive even then. A similar pattern emerged around the other important site of legal reform during this period, the cases on whether a husband could divorce his wife because she refused marital intercourse.

369. Id. at 582 .

370. Id. at 584.

371. James Schouler, A Treatise on the LaW of Husband and Wife 540 (Boston, Little, Brown, \& Co. 1882) (emphasis added).

372. B1SHOP, supra note 32, at 383 (quoting Sir John Nicholl).

373. BROWNE, supra note 337, at 103-04; see also BISHOP, supra note 32, at 384 ("“A blow between parties in the lower conditions and in the highest stations of life, bears a very different aspect."” (quoting Sir John Nicholl)); PAGE, supra note 345, at 144-45 ("[I]f a nobleman of high rank and ancient family, uses personal violence to his wife ... such conduct, in such a person, carries with it something so degrading to the husband, and so insulting and mortifying to the wife, as to render the injury itself far more severe and insupportable."). 


\section{B. A Wife's Refusal of Marital Intercourse as Grounds for Divorce}

In the last third of the nineteenth century, a number of husbands sued for divorce, claiming either desertion or cruelty on the ground that their wife had left the marital bed and refused all marital intercourse. These were not cases in which a wife had departed from her husband's household. During the time periods at issue in these suits, the wife had remained in her husband's house and continued to perform domestic and childcare services for him and the family. The only services the wife would not perform were sexual. A majority of the courts that heard these petitions denied them. The denials constituted an important, but highly incremental, victory for married women.

In these divorce suits, husbands had named their wives as the party at fault. Divorce always placed tremendous social and economic burdens on woinen in the nineteenth century. These burdens were exponentially intensified when the wife was adjudged to be the guilty party. That judgment carried tremendous social stigma for women. More concretely, alimony and dower (a wife's common law right to a life estate in one-third of her husband's real property at his death ${ }^{374}$ were not available at common law to wives found to be responsible for their divorce, and any property a wonian brought into her marriage remained vested with her husband. ${ }^{375}$ Denying a husband's divorce petition spared his wife the hardship of negotiating life as a divorced woman held responsible for her own condition. These decisions also represented some legal toleration of a wife's refusal to submit to intercourse, at least to the extent of holding that this was not a sufficiently bad act to merit divorce.

The boundaries of this reform were severely limited, of course. Even if a court refused to grant a husband a divorce, a judgment on a divorce petition did not prevent a man from forcibly compelling his wife to submit to intercourse or from placing her under various nonphysical forms of

374. On alimony and dower, see MANSFIELD, supra note 29, at 292-93; RoDGERs, supra note 31, at 320-21; ScHouler, supra note 19, at 11; BASCH, supra note 18, at 53; Siegel, Home as Work, supra note 11 , at 1082 .

375. See Address of Elizabeth Cady Stanton, on the Divorce Bill, Before the Judiciary Committee of the New York Senate, in the Assembly Chamber, Feb. 8, 1861, supra note 157, at 5 ("The laws on divorce are quite as unequal as those on marriage; yes, far more so.... [I]f the husband be the guilty party, he still retains a greater part of the property! If the wife be the guilty party, she goes out of the partnership penniless."); Joel PRENTISs Bishop, CommentaRies on the LAW of MARriage AND Divorce 416 (Boston, Little, Brown \& Co. 2d ed. 1856); MANSField, supra note 29, at 254; PAGE, supra note 345, at 293; REEVE, supra note 43, at 210; RoDGERS, supra note 31 , at 376-77. By the middle of the nineteenth century, only a few state legislatures had altered the common law rule. See BISHOP, supra, at 416.

Even in jurisdictions where a "guilty" wife could collect alimony, a finding of fault typically led to much smaller payments. See Tumbleson v. Tumbleson, 79 Ind. 558, 559-60 (1881) ("Ordinarily, where a wife ... is divorced without her fault, she ought to receive as alimony more than $\$ 100$ where her husband's property is worth $\$ 2,500$. But the appellant did not fulfil her obligations as a wife. ... [so] the decree of the court below for alimony was large enough."). 
pressure to acquiesce. Denying a husband a divorce also did nothing to make divorce a more viable economic and social option for women who might have preferred, everything else being more equal, to live apart from their husbands. These decisions, moreover, did not help a wife who had left her husband's household entirely in order to escape his sexual demands. Finally, some of the courts that heard these cases granted the husband a divorce because his wife had refused marital intercourse. These judgments did not constitute a total defeat for the wives who resisted them: The existence of civil remedies for disgruntled husbands arguably left wives better off than if they had been perpetually subject to their husband's use of the self-help remedy of forced sex. But these divorces left women highly vulnerable nonetheless, and constituted judicial reinforcement of a husband's marital prerogatives. Let's begin, however, with the cases in which a husband's divorce petition failed.

In most of these cases, it was clear that the wife did not have a physiological condition that made sexual intercourse unusually hazardous or painful. These wives refused to submit to marital intercourse because they did not want to have any more children ${ }^{376}$ or because they no longer loved their husbands. ${ }^{377}$ One woman was protesting her husband's decision to allow their son to enlist in the Union army during the Civil War. ${ }^{378}$ Not only did the criminal law accord them no right to refuse, these wives could not have won a divorce suit for cruelty if their husbands had forced them to submit. But a majority of the courts that heard their stories denied

376. See Steele v. Steele, 8 D.C. (1 MacArth.) 505, 505 (1874) ("'T] he defendant had assigned as a reason for denying matrimonial intercourse to the complainant that she did not desire to have any more children."); Magill v. Magill, 3 Pittsburgh Rep. 25, 25-26 (Pa. Ct. C.P. Allcgheny County 1866) (assuming as true Mr. Magill's allegation that his wife made "declarations that she would never bear children to him"); see also Throckmorton v. Throckmorton, 11 S.E. 289, 292 (Va. 1890) ("[A]fter the birth of her fourth child, ... the plaintiff declared her intention never to have another child, or to permit the defendant to occupy her bed again, since which time they have occupied separate apartments, although there has been no actual separation ....").

377. See Watson v. Watson, 28 A. 467,467 (N.J. Ch. 1894) ("[U]pon the occasion of a disagreement, at which the husband, as he says, merely scolded her, the wife withdrew from his bed .... [Thereafter,] communications between the husband and wife were rude and severely constrained ...."); Scott v. Scott, 61 Tex. 119, 121 (1884) (noting "an occasional outbreak of temper on the part of the wife, improper and perhaps insulting expressions used towards the husband in the presence of third parties on a few occasions" and concluding "[t]he worst effect her words could possibly have had was to make bystanders believe that his wife had but little respect for him, and perhaps no love, and gave vent to her feelings at ill chosen times").

378. See Southwick v. Southwick, 97 Mass. 327, 327-28 (1867) ("[T]aking offence because the husband allowed their eldest son to enlist in the army, [she] withdrew from the [marital] bed-room ...., and from that time occupied at night a separate bed-room from which she constantly excluded her husband .... No considerations of health or physical disability appeared to justify her refusal ....”). Miranda Southwick elaborated at the time "that she 'did n't intend to have any more boys for Mr. Southwick to send to the war,' that she 'had no love for him,' ... and that 'he was nothing but a boarder." Id. at 328 . 
their husbands a divorce nonetheless. ${ }^{379}$ The reasoning offered in these cases was similar. Where a husband had sued for desertion, courts held that "desertion" signified the renunciation of all marital obligations. Married women certainly had a duty to have intercourse with their husbands, judges explained, but this was only one of many duties. ${ }^{380}$ So long as a wife contmued to perform her other obligations, she had not deserted. ${ }^{381}$

The courts took two other sorts of wifely obligations to be particularly essential. First, they eniployed the language of companionate marriage to explain that a wife was duty-bound to live in the same household as her husband. Desertion meant "a cessation of cohabitation, a refusal to live together," 382 which would deprive the deserted party "of all real compamonship. ${ }^{383}$ Second, they focused on a wife's obligation to provide uncompensated domestic services to her husband and children, "the thousand ministrations to the physical comforts ..., in consideration of the marriage obligation, and without ceaseless thought of pecuniary

379. See Steele, 8 D.C. (1 MacArth.) at 506; Fritts v. Fritts, 28 N.E. 1058, 1058-59 (Ill. 1891); Stewart v. Stewart, 7 A. 473, 474 (Me. 1887); Southwick, 97 Mass. at 328-29; Segelbaum v. Segelbaum, 39 N.W. 492, 493 (Minn. 1888); Watson, 28 A. at 468; McKinney v. McKinney, 9 Ohio Dec. 655, 657 (Hamilton C.P. 1900); see also Reid v. Reid, 21 N.J. Eq. 331, 332-33 (Ch. 1871) (holding that husband's desertion of his wife was not justified by fact that she had refused him marital intercourse); Throckmorton, 11 S.E. at 292 (holding that husband had not deserted wife where he occupied a separate bedroom at her insistence).

380. See Stewart, 7 A. at 474 ("Sexual intercourse is only one marital right or duty. There are many other important rights and duties. The obligations the parties assume to each other and to society are not dependent on this single one."); Southwick, 97 Mass. at 329 ("[The] refusal of matrimonial intercourse ... [is] a breach or violation of a single conjugal or marital duty or obligation only ...."); Watson, 28 A. at 468 ("The lawfulness of [sexual] intercourse is perhaps a prominent and distinguishing feature of married life, but it is not the sum and all of it.").

381. See Fritts, 28 N.E. at 1058 ("We think that the willful desertion here referred to [in the Illinois divorce act] was intended to mean the abnegation of all the duties of the marital relation, and not of one alone."); Stewart, 7 A. at 474 ("We do not think our legislature intended to call the denial of this one obligation an 'utter desertion,' while the party might be faithfully, and perhaps meritoriously, fulfilling all the other marital obligations."); Southwick, 97 Mass. at 328-29 ("The word desertion in the statute... [signifies] an abnegation of all the duties and obligations resulting from the marriage contract."); Watson, 28 A. at 468 ("[T] he deserted party must be deprived of . . every substantial duty which the other owes to him or her."); see also BRowne, supra note 337, at 153 ("Refusal of sexual intercourse, although not occasioned by considerations of health, does not justify desertion. A refusal to cohabit implies much more than a refusal of sexual connection.").

Danforth v. Danforth, 33 A. 781 (Me. 1895), represents the flip side of these cases. Here, a court found desertion where a wife had left her husband's house, but had engaged in sexual intercourse with him for one brief period during their separation. Just as the cases above held that a refusal of marital intercourse, standing by itself, was not sufficient to establish desertion, Danforth held that the presence of marital intercourse, standing by itself, was not sufficient to defeat a desertion claim. See id. at 781 .

382. Southwick, 97 Mass. at 329; see also The AMERICAN AND ENGlish ENCYClopedia OF LAW, supra note 32, at 800 ("One of the elements of desertion is that the parties must have separated; there must be a cessation of cohabitation. Ceasing to cohabit means . . ceasing to have a common home. It does not mean ceasing to have sexual intercourse." (citing Southwick, Reid, Steele)).

383. Watson, 28 A. at 468. 
recompense."384 Phrased another way, then, the courts that denied husbands a divorce for desertion when their wives refused sexual intercourse made clear that these women were still subject to deep obligations to their husbands, including obligations that men did not bear in return. They also explained that a husband retained his sexual prerogatives. The only departure in these cases was their finding that sexual prerogatives were not the irreducible core of the marital relation.

The courts that rejected husbands' divorce petitions for cruelty presented a related line of argument. ${ }^{385}$ They agreed that a wife had the duty to submit to marital intercourse, a duty that the wives at issue had violated without just cause. ${ }^{386}$ But they reasoned that a divorce for cruelty was only available to a man who could demonstrate that his health or life had been endangered by his wife's conduct. ${ }^{387}$ The petitioning husbands had made

384. Id.; see also Segelbaum, 39 N.W. at 493 ("[T]he parties lived together as husband and wife from the date of their marriage until February 27, 1884, she having the care of their household and children, except that from the month of January, 1883, until the commencement of this action, she has refused to occupy his bed.").

385. See Cowles v. Cowles, 112 Mass. 298, 298 (1873); Magill v. Magill, 3 Pittsburgh Rep. 25, 26-27 (Pa. Ct. C.P. Allegheny County 1866); Scott v. Scott, 61 Tex. 119, 120-21 (1884).

During the same period, several wives also unsuccessfully sued for divorce on the ground of cruelty where their husbands had denied them marital intercourse. See Burton v. Burton, 27 A. 825 , 826 (N.J. Ch. 1893); Disborough v. Disborough, 26 A. 852, 853 (N.J. Ch. 1893); Duhme v. Duhme, 3 Ohio Dec. Reprint 95, 97, 100 (Hamilton C.P. Ct. 1859); Schoessow v. Schoessow, 53 N.W. 856, 857 (Wis. 1892); see also Eshbach v. Eshbach, $23 \mathrm{~Pa} .343,343,345$ (1854) (holding that husband's refusal to "cohabit with respondent as man and wife" did not justify wife's desertion, as "the fact that the husband lay in a separate bed" was not cruelty).

386. See Magill, 3 Pittsburgh Rep. at 26 ("It cannot be denied that such conduct ["the refusal of a wife to allow her husband his marital rights" $l$ is a violation of the marital vows, and greatly calculated to provoke unkind feelings on the part of the husband...."); see also 1 Joel Prentiss Bishop, Commentaries on the Law of Marriage and Divorce 566 (Boston, Little, Brown, \& Co. 6th ed. 1881) ("The law gives the husband the right to have his wife occupy the same bed with himself. But, if she refuses his embraces, it is not cruelty in her toward him [citing Cowles]. On the other hand, if he forces her, it is not rape.").

387. See Cowles, 112 Mass. at 298 ("[T] injury to life, limb, or health, or create a danger of such injury, or a reasonable apprehension of such danger.") (citation and internal quotation marks omitted); Magill, 3 Pittsburgh Rep. at 27 ("Judge King [has stated that] ... 'In limiting our intervention in matrimonial cases, in which cruelty is charged, to cases in which life or health are in any way involved, we occupy safe and prudent grounds.' This seems to me to comprehend the true principle....") (citation omitted); Scott, 61 Tex. at 121 ("[U]nless the excesses charged are such as produce bodily harm or the fear of it, a divorce cannot be granted."); see also BISHOP, supra note 328, at 612 ("[T]his doctrine [that withholding marital intercourse is not cruelty], to be sound, as applied to cases where no good reason, such as the health of the party refusing, prompts the refusal, must proceed on the assumption that the health of the other party is not injured thereby.").

For similar physiological reasoning in cruelty cases where the wife was the petitioner for divorce, see Burtom, 27 A. at 826 ("I do not think that such separation from bed and home is 'extreme cruelty,' as used by the statute, in the absence of evidence that it has had, or tends to have, serious effect upon the health of the wife. There is no such evidence in this case."); Duhme, 3 Ohio Dec. Reprint at 100 ("[T]he law has defined [extreme cruelty]. It says there must be either personal violence, or the reasonable apprehension of personal violence; or a systematic course of ill treatment, affecting the health and endangering the life of the party against whom it is directed."); Schoessow, 53 N.W. at 857 
no showing to that effect, and accordingly lost their divorce suits. ${ }^{388}$ One court, moreover, expressed doubts about whether a man would ever be able to make such a showing. "If non-access to a man or woman's bed has such startling effects," a Pennsylvania judge remarked, "a great portion of our race must be in a pitiable condition. ${ }^{p 899}$ These decisions carved out a small space for female resistance in an interesting way. They did not excuse or express empathy for the wives who demed their husbands marital intercourse. They argued, in essence, that their husbands had overreacted to this breach of duty, that the harm caused was not as troubling as the men suggested. This judgment did not challenge a husband's marital prerogatives, but it helped undercut one possible defense for those prerogatives (a defense already fiercely disfavored in the prescriptive literature): naniely, the theory that healthy male physiology necessarily and always depended on regular sexual outlet.

No notable case law, moreover, disputed this understanding of legal cruelty ${ }^{390}$ Courts granting divorce petitions because a wife refused marital intercourse relied on desertion rationales. In particular, they adopted the arguments that a number of treatise writers, including most prominently Joel Bishop, urged with great force during this period. ${ }^{391}$ Bishop noted that

("[T]he bare fact of refusal to permit sexual intercourse ... does not, either in reason or authority, constitute 'cruel and inhuman treatment.' No injury to the plaintiff, either mental or bodily, is alleged or proven to have resulted from such refusal; nor is her health claimed to have been impaired.").

388. See Scott, 61 Tex. at 121 ("To put the worst phase upon the conduct of the wife in this case, there is nothing in what she said or did from which the husband could possibly fear that she would do him bodily harm ....").

389. Magill, 3 Pittsburgh Rep. at 26.

Three treatise writers were more confident that some husbands, at least, might potentially be able to demonstrate the requisite injury to their health. William Nelson suggested an analogy to the impotency jurisprudence, where medical testimony in one case had established "that if the wife continued to occupy the same bed with her impotent husband her health would be impaired and her nervous system so injured that she would be subject to hysteria by her being obliged to occupy his bed without proper gratification of passions thereby excited. Under similar testimony," he reasoned, "it is possible that our courts would grant a divorce for persistent refusal of sexual intercourse." NELSON, supra note 32, at 331. Bishop also relied on the impotency case law to conclude "that a capable person, whether man or woman, may in this way inflict an injury to the health of the other party to the marriage on account of which a divorce for the cruelty ought to be granted." Bistop, supra note 328, at 612-13. Browne simply asserted that "it [was] undoubtedly the fact that a capable party refusing to cohabit, may inflict an injury to the health of the other, where they sleep together, which might be cruelty." BROWNE, supra note 337 , at 111 .

390. See, e.g., Holyoke v. Holyoke, 6 A. 827, 829 (Me. 1886) (holding that a husband could make out a claim for cruelty based, inter alia, on his wife's refusal of marital intercourse, but only if he could establish at trial that his wife's actions had "seriously injure[d] or threaten[ed] to injure and impair [his] physical health").

391. See Heermance v. James, 47 Barb. 120, 126 (N.Y. App. Div. 1866) ("It is laid down by Bishop... that the refusal of the husband or wife to dwell with the other party to the marriage; as husband or wife, is desertion. The same authorities hold that there may be desertion though the parties continue to occupy the same house."). This case arose in a somewhat unusual posture. The Heermance court had to determine whether Rachel Heermance had deserted her husband, in order to resolve an alienation of affections suit that Mr. Heermance had brought against another man, Mr. James. See id. at 
the right to engage in licit sexual intercourse existed only within the marital relation. He took this to mean that marital intercourse was, in fact, the defining mark of marriage. ${ }^{392}$ So that if a wife refused sex without cause, one could no longer characterize her relationship with her husband as marital. ${ }^{393}$ Bishop also drew analogies to the jurisprudence of impotency, which held that incapacity at the time of marriage was ground for dissolution because the impotent party could not perform all of the obligations of the relation. ${ }^{394}$ This analogy was not perfect, as impotency

121-23. Heermance found desertion on a demurrer, although Mrs. Heermance had not left her husband's house, because she had allegedly refused him marital intercourse. See id. at 125-27. For cases holding that a husband could win a divorce for desertion on the ground that his wife had denied him intercourse, see Whitfield v. Whitfield, 15 S.E. 543, 543 (Ga. 1892) (per curiam) (quoting husband's testimony that his wife "continued to live in the same house in which we had previously lived, ... but would never recognize me as her husband. . . . [She said] more than once that she would have her throat cut from ear to ear before she would do so."'); Leach v. Leach, 27 P. 131, 132 (Kan. 1891) (" $[T]$ he refusal of the defendant to cohabit with the plaintiff as his wife for more than five years ... was sufficient [to authorize a divorce for "gross neglect of duty"']. Probably a much shorter period of time would be sufficient ....").

Several cases also granted women divorces for desertion where their husbands had remained in the same house but ceased having marital intercourse with them. See Stein v. Stein, 5 Colo. 55, 56-57 (1879); Evans v. Evans, 20 S.W. 605, 606 (Ky. 1892).

In addition, Fitts v. Fitts, 46 N.H. 184, 184-85 (1865), and Dyer v. Dyer, 5 N.H. 271, 272-74 (1830), granted divorces under specific New Hampshire statutes that permitted marital dissolution where the petitioner's spouse had joined a religious society that took marital intercourse to be unlawful (for example, the Shakcrs).

392. See BISHOP, supra note 386, at 586 ("[T]here is but the one thing, which is special to marriage, and is lawful in no other relation. All else pertaining thereto a man and woman may mutually contract for, and do, without taking the first step toward marriage.").

393. Heermance quoted a key passage from Bishop:

"It may be laid down as a rule, (says Bishop,) that if one party refuse to the other whatever belongs to marriage alone, from causes resting in the will, and not from physical inability, the refusing party would thereby voluntarily withdraw from whatever the relation of marriage, distinguished from any other relation existing between human beings, is understood to imply; therefore he should be holden to desert thereby the other."

Heermance, 47 Barb. at 126-27. Sisemore v. Sisemore, 21 P. 820 (Or. 1889), approvingly quoted a similar passage from Bishop, but in that case the wife had both refused marital intercourse and left her husband's house, see id. at 821-22; see also Stein, 5 Colo. at 56-57 ("Matrimonial cohabitation must certainly comprehend a living together as husband and wife, embracing relative duties as such. Otherwise, all the married couples residing in a hotel, boarding or lodging house, might be said to be cohabiting promiscuously."); NELSON, supra note 32, at 115-16 ("Desertion . . . means the ceasing to live together as husband and wife. Marriage is the union of opposite sexes, and sexual intercourse is the distinguishing feature of that union.... [This] is an undisputed faet of nature recognized in many ways in our laws. Such intercourse is lawful only in marriage."); ScHouler, supra note 30, at 63 ("Living in the same house, but wilfully declining matrimonial intimacy and companionship, is per se a breach of duty, tending to subvert the true ends of marriage.").

394. See BisHop, supra note 328, at 649-50 ("[The common law] makes the marriage voidable where from the time of its solemnization onward there is no power of copula .... [I]f the ends of marriage are frustrate when there is no power of copula, much more are they so when the same thing is wilfully and perpetually refused."); see also NELSON, supra note 32, at 117 ("If the impotence of a party defeats the purpose of marriage, it must be conceded that a wilful, continued and unjustifiable refusal of sexual intercourse will do so, especially where the party remains in the same house to create further discord and hatred by her harrowing presence.") (citation and internal quotation marks omitted). 
that developed after the wedding did not provide cause for termination..$^{395}$ But Bishop did state that he would exempt women who had physiological reasons for their refusal from divorce for desertion. ${ }^{396} \mathrm{With}$ that caveat in place, Bishop-and the minority of courts that followed his line of reasoning-positioned a wife's duty to submit to her husband's sexual demands at the center of the marital relation and sought to reinforce a husband's marital prerogatives through civil judgments for desertion.

The law's treatment of marital rape was not the product of consensual agreement in the nineteenth century. The vision of marital rape as uncontested terrain until the last quarter of the twentieth century effaces a vibrant movement in opposition. Feminists, in the first organized woman's rights movement and on its left-ward periphery, demanded a woman's right to control her own person in marriage, arguing for both an enforceable prerogative to refuse marital intercourse and palatable socioeconomic alternatives to submission. This campaign was intense, public, and remarkably frank. It recognized marriage as a potentially antagonistic or abusive relation, and strove to provide women with rights and resources they could utilize independent of their husbands' agreement, to defend themselves from a husband's unwanted sexual demands.

This was a radical agenda, yet criticism of marital rape was neither unthinkable nor unspeakable in the popular discourse of the latter half of the nineteenth century. Very soon after the woman's rights movement initiated its public battle against marital rape, sustained accounts of the harm that marital rape inflicted on wives began to appear in the mainstream prescriptive literature on marriage, reproduction, and health. This literature, however, did not support legal change. Instead, it urged husbands to practice voluntary restraint, on the ground that the concession would benefit them at least as much as their wives. In the pages of the prescriptive literature, the feminist rights discourse was recast as a series of suggested strategies for marital harmony, health, and happiness. The popular prescriptive literature promised that the interests of husbands and wives were actually and always aligned on the question of marital rape, but left final control over a wife's person with her husband, to be wielded at his discretion.

395. See supra note 36 and accompanying text.

396. See Bishop, supra note 32, at 407 ("But if, aside from all special or temporary considerations, as of health, a wife should utterly refuse to dwell with her husband as a wife, why is not such refusal, upon principle, a desertion, even though she consent to remain with him as a servant, or a daughter?"); Heermance, 47 Barb. at 126 (quoting Bishop for proposition that only a person who refused marital intercourse "from causes resting in the will, and not from physical inability" would be vulnerable to divorce for desertion); see also ScHOULER, supra note 371, at 559 ("[W]e would suggest that, by a slight stretch of statute construction, one partner's denial of sexual intercourse, ... if persisted in wilfully, without some proper excuse such as ill health might furnish, ... might, upon the usual lapse of time, be treated as legal desertion ...."). 
Ultimately, the law's treatment of marital rape changed just marginally in the latter half of the nineteenth century. Women never won the right to control their own persons in marriage that ferminists had sought. Indeed, by century's end, the only legal protection a wife could muster against an uncooperative husband was the slender solace provided by tepid liberalization of the divorce law. Social recognition of the harm and prevalence of marital rape was widely disseminated. Yet authoritative legal sources-like popular prescriptive authors-remained unwilling to structure women's legal rights around the proposition that spousal negotiations over the terms of marital intercourse might be a site of divergent interests and danger, where wives needed and justly deserved the ability to protect themselves from their husbands.

\section{$\mathrm{V}$}

\section{The Modern Debate over the Marital Rape Exemption}

As the feminist movement increasingly turned its attention to suffrage in the early twentieth century and then lost much of its organizational spark after suffrage was won, ${ }^{397}$ debate over marital rape dwindled. The first sustained contest over marital rape was coterminous with the life span of the first woman's rights movement in the United States. Begun almost immediately upon the organization of nineteenth-century feminism, it dissipated when the movement disbanded ${ }^{398}$ It was not until the last quarter of the twentieth century that the legal status of marital rape was again subject to significant attack, led this time by the second organized women's movement. Here too, however, the resulting reform has been partial and uneven.

397. See BUECHLER, supra note 27, at 148-215; FLEXNER, supra note 23, at 222-345; KRADITOR, supra note 136, at 261-64. As Nancy Cott has observed, many women channeled their energy in the early twentieth century into voluntary organizations that were predominantly female in membership, but not feminist. She explains:

What some of the older generation likely missed in modern women's organizations was the emphasis on womanhood, the proudly sex-defined sentiment that had powered so many earlier associations.... The newer women's organizations were so more by habit and expedience than commitment, it might be said.... Where their nineteenth-century predecessors collectively constituted the woman movcment and would have recognized themselves as such, the twentieth-century women's voluntary associations did not collectively constitute the feminist movement-nor would most members have recognized themselves as feminists; indced, they had varying and ambivalent relations to feminism, some opposing it directly.

NANCY F. COTT, THE GROUNDING OF MODERN FEMINISM $96-97$ (1987).

398. As Rebecca Ryan's history of the marital rape exemption in the period after World War II notes, authoritative legal sources in this period felt little need to reconsidcr their commitment to the exemption before the rise of the modern feminist movement in the 1970s. See Rebecca M. Ryan, The Sex Right: A Legal History of the Marital Rape Exemption, 20 L. \& Soc. 1NQUIRY 941, 942-43 (1995); see also id. ("[A]lthough the professional culture formally rejected the principle of marital unity during the carly 20th century, the male scx right remained fundamental to postwar legal scholars' conception of marriage.... [T] he postwar legal elite [accordingly] created hypocritieal arguments that left the exemption open for attack."). 
Divorce is now widely available. Indeed, every state has enacted some form of no-fault divorce in recent years, ${ }^{399}$ so that the law of cruelty and desertion has become far less important and developed. But the possibility of divorce, now as in the mineteenth century, does nothing to alter the law governing intact marriages. ${ }^{400}$ Moreover, many of the practical obstacles to divorce that women confronted in the nineteenth century remain in place to a significant extent today. Most notably, divorce is still economically disastrous for the average woman, especially if she is raising children. ${ }^{401}$

As for the law of fault-based divorce, the one site of legal reforn in the nineteenth-century treatment of marital rape, it is difficult to draw generalizations from the handful of cases published in the last quarter century in which a wife sought a divorce for cruelty based on her husband's unwanted sexual deinands. The few cases that do exist, however, do not stray far froin the nineteenth-century regime, with courts taking care in the successful suits to note a husband's "excessive"402 or "persistent" ${ }^{403}$ sexual demands and/or the injury that the husband's

399. In 1969, California became the first state to eliminate fault-based divorce entirely. In 1985 , South Dakota became the last state to incorporate some no-fault provision into its divorce laws. See Herma Hill Kay, Beyond No-Fault: New Directions in Divorce Reform, in Divorce Reform at The Crossroads 6, 6 (Stephen D. Sugarman \& Herma Hill Kay eds., 1990); see also Herma Hill Kay, Equality and Difference: A Perspective on No-Fault Divorce and Its Aftermath, 56 U. CIN. L. REv. 1, 5-6 (1987) [hereinafter Kay, Equality and Difference] (classifying and reviewing no-fault divorce laws).

400. See supra Part IV.A.

401. Lenore Weitzman has published the best-known work on this subject. See LENORE J. Weitzman, The Divorce Revolution (1985). Her study, based on evidence from California, found that divorced women and their children experienced an average $73 \%$ drop in their standard of living in the first year after the divorce, while divorced men saw their standard of living rise by $42 \%$. See id. at 323. Several scholars have challenged Weitzman's methodology and the extremity of her results. See, e.g., Saul D. Hoffman \& Greg J. Duncan, What Are the Economic Consequences of Divorce?, 25 DEMOGRAPHY 641 (1988); Richard R. Peterson, A Re-evaluation of the Economic Consequences of Divorce, 61 AM. Soc. REV. 528 (1996). But a number of studies confirm the fundamental proposition that divorce leaves the average woman and her children substantially worse off economically than they were before. See, e.g., Rosalyn B. Bell, Alimony and the Financially Dependent Spouse in Montgomery County, Maryland, 22 FAM. L.Q. 225, 284 chart 6 (1988) (reporting that mean per capita income of women awarded alimony in contested adjudications declined by $37 \%$ after divorce and income of their children declined by $61 \%$, while their former husbands' income rose by $55 \%$ ); Greg J. Duncan \& Saul D. Hoffman, A Reconsideration of the Economic Consequences of Marital Dissolution, 22 DEMOGRAPHY 485, 488 (1985) (finding that in the first year following divorce or separation "the family income of women who do not remarry is 70 percent of its previous figure; five years after a divorce or separation, the ratio for those still unmarried is 71 percent"); Barbara R. Rowe \& Jean M. Lown, The Economics of Divorce and Remarriage for Rural Utah Families, 16 J. CONTEMP. L. 301, 324-25 (1990) (reporting that the divorced women in the study experienced a 32\% decrease in their standard of hiving, while the men experienced a 73\% rise); Heather Ruth Wishik, Economics of Divorce: An Exploratory Study, 20 FAM. L.Q. 79, 97 tbl.14 (1986) (calculating per capita income after divorce on the assumption that all support ordered was paid, and reporting that women's mcome still declined by $33 \%$, children's declined by $25 \%$, and men's rose by $120 \%$ ).

402. Pochop v. Pochop, 233 N.W.2d 806, 808 (S.D. 1975).

403. Lemley v. Lemley, 649 A.2d 1119, 1128 (Md. Ct. Spec. App. 1994). 
conduct has caused to his wife's health. ${ }^{404}$ There has been more change in the sparse modern jurisprudence on whether a husband is entitled to a fault-based divorce when his wife denies him sexual intercourse, but that movement has been in favor of accepting the husband's claim. Although most courts rejected such petitions at the end of the nineteenth century, ${ }^{405}$ a majority of the courts that have addressed the question since 1975 have granted fault-based divorces for refusal to have sex..$^{406}$

Reform of the criminal exemption has also been fragmentary. A majority of states still retain some form of the rule exempting a husband from prosecution for raping his wife. ${ }^{407}$ Some states require a couple to be separated at the time of the injury (and sometimes extend the exemption to cover unmarried cohabitants). ${ }^{408}$ Some only recognize marital rape if it involves physical force and/or serious physical harm. ${ }^{409}$ Some provide for

404. See id. (holding that a "coerced sexual performance" is "indeed inconsistent with the health, self-respect and comfort of the other spouse" and affirming judgment "that it was necessary for [Mrs. Lemley] to leave the home to protect her physical and emotional health") (citations and internal quotation marks omitted); Richardson v. Richardson, 589 N.Y.S.2d 624, 625 (App. Div. 1992) (noting that wife had been subject, inter alia, to "the physical and emotional strain caused by [her husband's] insistence that [she] conform to his sexual wishes" and citing wife's testimony that her husband "pressured her to perform sexual acts which were physically painful or humiliating to her and caused her to vomit").

405. See supra Part IV.B.

406. For cases granting a husband a divorce for cruelty or desertion based on his wife's refusal to have sexual intercourse, see Wheelahan v. Wheelahan, 557 So. 2d 1046, 1050-52 (La. Ct. App. 1990) (cruelty); Coleman v. Coleman, 541 So. 2d 1003, 1006 \& n.5 (La. Ct. App. 1989) (cruelty); Broussard v. Broussard, 462 So. 2d 1386, 1389 (La. Ct. App. 1985) (cruelty); Taddonio v. Kinney-Taddonio, 428 So. 2d 486, 487-88 (La. Ct. App. 1983) (cruelty); Dickinson v. Dickinson, 399 So. 2d 651, 652 (La. Ct. App. 1981) (cruelty); Culver v. Culver, 383 So. 2d 817, 817-18 (Miss. 1980) (cruelty); Silvcr v. Silver, 677 N.Y.S.2d 593, 594-95 (App. Div. 1998) (desertion); Donohue v. Donohue, 636 N.Y.S.2d 104, 105 (App. Div. 1995) (desertion); Chase v. Chase, 618 N.Y.S.2d 94, 95 (App. Div. 1994) (desertion); Caso v. Caso, 555 N.Y.S.2d 820, 821 (App. Div. 1990) (desertion).

For the same holding where the wife was the plaintiff, see Barr v. Barr, 473 A.2d 1300, 1307 (Md. Ct. Spec. App. 1984) (desertion); Haymes v. Haymes, 675 N.Y.S.2d 593, 594 (App. Div. 1998) (desertion); Tissot v. Tissot, 662 N.Y.S.2d 599, 600-01 (App. Div. 1997) (desertion); Pascarella v. Pascarella, 621 N.Y.S.2d 821, 822 (App. Div. 1994) (desertion); Ostriker v. Ostriker, 609 N.Y.S.2d 922, 923 (App. Div. 1994) (desertion); Benarroch v. Benarroch, 391 N.Y.S.2d 138, 139 (App. Div. 1977) (desertion); Riechers v. Riechers, 679 N.Y.S.2d 233, 234 (Sup. Ct. 1998) (desertion).

For a case holding that a wife's refusal of sexual intercourse does not constitute desertion entitling the husband to divorce, see Preston v. Preston, Nos. 0071-97-4, 0175-97-4, 1998 WL 15137, at*1-2 (Va. Ct. App. Jan. 20, 1998).

407. See supra notes 1-3 and accompanying text.

408. See, e.g., MiNN. STAT. $\$ 609.349$ (1987) ("A person does not commit criminal sexual conduct .... if the actor and complainant were adults cohabiting in an ongoing voluntary sexual relationship at the time of the alleged offense, or if the complainant is the actor's legal spouse, unless the couple is living apart and one of them has filed for legal separation or dissolution of the marriage."); S.C. CodE ANN. \$ 16-3-658 (Law. Co-op. Supp. 1999) ("A person cannot be guilty of criminal sexual conduct ... if the victim is the legal spouse unless the couple is living apart and the offending spouse's conduct constitutes criminal sexual conduct in the first degree or second degree.....").

409. See, e.g., NEv. REv. STAT. \$ 200.373 (1997) ("It is no defense to a charge of sexual assault that the perpetrator was, at the time of the assault, married to the victim, if the assault was committed 
vastly reduced penalties if a rape occurs in marriage, ${ }^{40}$ or create special procedural requirements for marital rape prosecutions ${ }^{411}$ Almost all of this law, moreover, is the product of political advocacy and legislative action, rather than constitutional adjudication, ${ }^{412}$ so that the nature and continued path of change is insecure. Enforcement of the existing statutes recognizing some forms of marital rape has certainly been very infrequent. ${ }^{413}$

This criminal arena is where modern Americans defending or contesting the legal status of marital rape have focused their attention. ${ }^{414}$ The history of the nineteenth-century campaign against marital rape casts new light on this modern debate over a husband's conjugal prerogatives and helps explain its course.

One of the niost remarkable characteristics of the modern defense of the marital rape exemption-apparent when considered in light of the historical contest over a husband's conjugal prerogatives but generally unnoticed in contemporary commentary-is that it presupposes the aligned interests of husband and wife. The two argunients that modern defenders of the exemption have chosen to stress most prominently are that the law protects narital privacy and promotes niarital harmony and reconciliation. These clains are slightly different, but they have a common project, which is to explain how the exemption advances the shared concerns of nien and women, benefitting both. Indeed, contemporary supporters of the exemption go beyond that contention. Their assumption of conjoined interests in marriage is so absolute that proponents do not concede that a marital rape exemption might inflict harm on wives. Their argument assumes that a wife's interests, like her husband's, are always and wholly served in a niarital relationship where her husband cannot be prosecuted for raping her. In the exemption's modern defense, the potential harm of marital rape is rendered invisible.

\footnotetext{
by force or by the threat of force."); TENN. CoDE ANN. § 39-13-507(b)(1) (Supp. 1999) ("'Spousal rape' means the unlawful sexual penetration of one spouse by the other where: (A) The defendant is armed with a weapon . . . ; (B) The defendant causes serious bodily injury to the victim; or (C) The sponses are living apart and one (1) of them has filed for separate maintenance or divorce.").

410. See statutes cited supra note 2.

411. See statutes cited supra note 3 .

412. See infra notes $470-471$ and accompanying text.

413. See infra note 423 .

414. The recent abrogation of interspousal tort immunity in most states, see Carl Tobias, Interspousal Tort Immunity in America, 23 GA. L. REv. 359, 359 (1989), suggests that wives might be able to sue their husbands civilly for damages arising out of a marital rape. Thus far, however, few cases have been brought presenting the issue. For two rare examples, see Henriksen v. Cameron, 622 A.2d 1135, 1137, 1143 (Me. 1993) (permitting suit against former husband for intentional infliction of emotional distress during marriage, where underlying conduct included marital rape); Lusby v. Lusby, 390 A.2d 77, 77-78 (Md. 1978) (bolding that wife could bring damage claim against husband, where husband threatened her with a rifle, struck her, raped her, and helped his two companions attempt to rape her).
} 
This strategy has been very successful, modern feminist efforts against the exemption notwithstanding. To some extent, the consensual vision that dominates the contemporary understanding of the history of marital rape helps account for the influence that the exemption's modern champions have enjoyed. If one starts with the premise that women have long accepted husbands' conjugal prerogatives without protest, the notion that the exemption continues to operate to the shared benefit of a married couple is likely to seem much more tenable. At the same time, it would be unrealistic to suppose that the modern commitment to the exemption would somehow vanish, if the actual record of contest over a husband's conjugal prerogatives became well-known. As that history makes clear, the cultural aversion to envisioming marriage (and marital intercourse in particular) as a potential site of disharmony, antagonism, and danger is long-lived, widespread, and exceedingly difficult to uproot.

Yet the fact that the exemption's contemporary defenders go so far as to deny that a marital rape exemption inflicts harm on women provides a clue as to how modern femimists might proceed. In the nineteenth century, popular prescriptive writers and authoritative legal sources opposed to granting married women legal control over their persons felt free, nonetheless, to acknowledge that marital rape caused women serious harm; they were living in an age that still accepted and endorsed a wide variety of laws explicitly subordinating women to men. As the exemption's contemporary champions have apparently realized, it is much harder to rationalize the injury that marital rape inflicts, and to then justify the denial of legal remedies, in a nation that has become formally committed to women's legal equality. The record of the historical struggle over marital rape helps reveal this harm, bringing to light what the exemption's modern defenders have tried to obscure. On this base, the modern feminist campaign against marital rape can build.

\section{A. The Modern Defense of the Marital Rape Exemption}

The first prominent modern argument for the marital rape exemption, the claim from privacy, posits that there is something inherent in the nature of the relationship between husband and wife that makes legal intervention inappropriate, misguided, and ultimately self-defeating. It contends that the marital relation depends on intimacy protected from outside scrutiny, intimacy that could not survive if the law intervened to investigate and prosecute marital rape charges.

Contemporary defenders of the marital rape exemption do not articulate this privacy claim in sex-specific terms, or as a balancing test in which gains must be set against losses. They do not seek to explain why it is important to protect men's privacy in marriage through a marital rape exemption, even if women's interests may suffer. They make no mention 
of the possibility that marital rape or the absence of criminal remediation might inflict injury on wives. To the contrary, the exemption's modern defenders speak about protecting the privacy of the marital relationship that husband and wife share, of benefitting both. Consider, for instance, how a Florida state representative explained his support for a marital rape exemption: "'The State of Florida has absolutely no business intervening into the sexual relationship between a husband and a wife.... We don't need Florida invading the sanctity and the intimacy of a relationship. ${ }^{\prime \prime 415}$ The drafters of the Model Penal Code, who recommend an absolute marital rape exemption, similarly note that the exemption "avoids [an] unwarranted intrusion of the penal law into the life of the family." 116 Along the same lines, the Pennsylvania Superior Court interpreted a recent legislative modification of the exemption narrowly in order to stop the state from invading "the privacy of the marital bedroom for the purpose of supervising the manner in which marital relationships are consummated."177 The crucial claim of this privacy defense for the marital rape exemption is that keeping the judicial system away from disputes over marital rape serves the interests that a husband and wife both have in maintaining their joint privacy, that the exemption protects the intimacy that they have established with each other and from which each benefit unanibiguously. Marriage here is envisioned as a necessarily harmonious relation, and legal intervention as the first, unwelcome introduction of antagonism and injury.

The other prominent modern claim articulated in favor of the marital rape exemption, that it facilitates marital reconciliation, similarly explains the exemption as promoting the shared interests of wives and husbands. Building on the proposition that marital intimacy is destroyed by outside observation, this argument contends that the legal system should not be able to investigate or prosecute marital rape because such intervention will inake reconciliation between husband and wife significantly less likely. Once the state appears on the scene, the exemption's supporters suggest, the delicate shoots of love, trust, and closeness in a marriage will be trampled in a way unlikely ever to be undone. In contrast, if the exemption remains in place, this argument asserts that many married couples

415. Diana E.H. Russell, Rape in Marriage 18 (rev. ed. 1990) (quoting State Rep. Tom Bush) (emphasis added); see also id. ("'[T]he Bible doesn't give the state permission... to be in your bedroom, and that is just exactly what this bill has gone to. It's meddling in your bedroom; the State of Florida, as an entity, deciding what you can do and what you can't do."' (quoting State Rep. John Mica)).

416. Model Penal Code and Commentaries, supra note 5, at $\S 213.1 \mathrm{cmt} .8(\mathrm{c})$, at 345 (emphasis added).

417. Commonwealth v. Mlinarich, 498 A.2d 395, 403 (Pa. Super. Ct. 1985) (emphasis added); see also Michael Gary Hilf, Marital Privacy and Spousal Rape, 16 New ENG. L. Rev. 31,34 (1980) ("I]t is questionable whether the complaining spouse alone has the right to waive the marital privacy right of the couple by presenting the matter before the courts and the public.") (emphasis added). 
will be able to reconcile after what would otherwise be considered a marital rape. ${ }^{418}$

Here again, the central premise of the argument is that private reconciliation and the return to regular married life leave both wife and husband better off than they would have been if the state had been empowered to prosecute a marital rape. Supporters do not justify the exemption by explaining why the advantages to husbands of reconciliation without prosecution outweigh the potential costs to wives. They do not suggest that the interests of husband and wife might diverge like that. Modern defenders of the marital rape exemption do not even phrase their claim as a contention that a wife should sacrifice her own interests for the sake of her children, who may benefit from their parents' reconciliation, or for the sake of the broader societal benefits associated with marital stability. Their argument never acknowledges that the exemption inflicts an injury on wives that might (potentially) be justified by the benefits conferred on those around them.

Indeed, supporters go further than that and state that married couples are able to reconcile so completely after a rape that their relationship becomes essentially indistinguishable from other marriages, affirmatively denying the proposition that marital rape causes any lasting injury at all. In the view of the Colorado Supreme Court, "the marital exception may remove a substantial obstacle to the resumption of normal marital relations." ${ }^{419}$ The Model Penal Code similarly emphasizes the normality of the reconciliation process possible after a marital rape. As the Code's drafters note, "[t]he problem with abandoning the [marital] immunity in many such situations ['of rape by force or threat'] is that the law of rape, if applied to spouses, would thrust the prospect of criminal sanctions into the ongoing process of adjustment in the marital relationship." $" 420$

A less prominent contemporary defense of the marital rape exemption might be called the "vindictive wife" argument. This claim contends that the exemption should be preserved in order to prevent wives from pursuing false charges of marital rape, especially to gain leverage in a

418. See Hilf, supra note 417 , at 34 ("Allowing access to the criminal justice system for every type of marital dispute will discourage resolution by the spouses and will make their ultimate reconciliation more difficult."); id. at $34 \mathrm{n} .15$ ("There are two possible problems that can arise when marital disputes become involved with the legal system. First, knowlcdge by the spouscs that the law can step in may pose impediments to direct resolution of disagreements .... [Sccond,] interspousal efforts at reconciliation may well be frustrated by a rape prosecution."); Comment, Rape and Battery Between Husband and Wife, 6 STAN. L. REv. 719, 725 (1954) ("If reconciliation between married persons is to be encouraged, it would appear best to allow a husband to be prosecuted for rape only after absolute and final divorce. ... [R]ape is a category ill-suited to marriage.").

419. People v. Brown, 632 P.2d 1025, 1027 (Colo. 1981) (en banc) (emphasis added).

420. Model Penal Code and Commentaries, supra note 5 , at $\S 213.1 \mathrm{cmt}$. 8(c), at 345 (emphasis added). 
divorce suit. ${ }^{421}$ The line of reasoning openly recognizes the possibility of marital antagonism (at least at the end of a relationship), placing it in some tension with the more prominent claims for the exeniption from privacy and reconciliation. But there is a long, distinct tradition in AngloAmerican law, traceable once again to Hale's seminal treatise, advocating the particular disbelief of rape victims. Hale famously warned that rape was "an accusation easily to be made and hard to be proved, and harder to be defended by the party accused, tho never so innocent." 422 The vindictive wife argument for preserving the marital rape exemption accords well with this tradition. There is, after all, no empirical evidence to support the proposition that wives are prone to make false charges of marital rape. To the contrary, the evidence available from states that allow marital rape prosecutions suggests that the incidents that women report to law enforcement officials tend to be very brutal, and relatively easy to prove. ${ }^{423}$

421. See Iowa 'Marital Rape' Measure Is Moving, OMAHA WorLd-Herald, Mar. 24, 1989, at 16, 16 (quoting State Senator Joe Coleman, arguing that bill to reduce scope of marital rape exemption "“could cause a person to go to jail for 10 years just because of an argument at breakfast, maybe.... There are certain people who are always wanting to get even.... I think there are other remedies, rather than going after something that is natural and making that a criminal offense""); David Margolick, Rape in a Marriage Is No Longer Within Law, N.Y. TIMES, Dec. 23, 1984, at 6E, 6E ("In a nasty custody fight, where a husband and wife are really playing hardball, a woman could threaten that unless her husband became more reasonable, she would charge him with a rape she says he committed six months earlier,' [Professor Yale Kamisar of the University of Michigan Law School] said [arguing in favor of a limited marital rape exemption]."); George F. Will, When Custom Doesn't Work Anymore, WASH. Post, Dec. 28, 1978, at A23, A23 ("[T]he potential for abuse of the charge in divorce proceedings [is 'obvious']. It is less obvious that there are fully compensating social benefits from a law distinguishing from others this particular category of assault.").

422. HALE, supra note 64, at 635. For a discussion of the history of this argument in American courts, see supra note 69.

423. For example, the National Clearinghouse on Marital Rape (NCMR) identified 42 instances of marital rape that came to the attention of California law enforcement officials between January 1980 and December 1981. See DAvid Finkelhor \& KeRsti Yllo, License to RAPE: Sexual Abuse of WIVEs 222-23 (1985). Sociologists David Finkelhor and Kersti Yllo describe the cases this way:

The first thing to note about the cases compiled by the NCMR is that they were, on the whole, extremely brutal. The cases include one in which a woman was raped with a crowbar and a sixteen-inch tire iron and then had her breasts slashed with the same instruments.... The use of knives and guns was a common feature among these cases, and several included very severe beatings.

Id. at 223-24. The NCMR study found that the husband was convicted in $64 \%$ of the cases in which a charge was lodged, and $89 \%$ of the cases that reached prosecution. See id. at 230 . These figures compare favorably with the statistics for nonmarital rape-hardly evidence of a spate of vindictive wives pursuing false charges. The California State Department of Justice reports that in 1980, for instance, only $44 \%$ of all arrests for forcible rape resulted in conviction, and only $67 \%$ of the cases reaching prosecution resulted in conviction. See id. The high conviction rate in the NCMR study appears to be a function of the fact that the marital rape cases were disproportionately severe and easily proved.

The NCMR study constitutes probably the best available empirical evidence on what happens when a state repeals or limits its marital rape exemption. Social scientists have not focused on the issue, which is obviously complicated and made especially difficult to study by the fact that states often do not keep adequate statistics on marital rape. In California, for instance, the NCMR had to identify many 
More fundamentally, the vindictive wife defense of the marital rape exemption recognizes marital discord in a very particular, and limited, way. In this vision, the antagonistic and harmful act to be feared in marriage is not the possibility of an actual marital rape. The argument never suggests that the marital rape exemption may be shielding and facilitating injurious conduct inflicted by husbands on wives. To the contrary, it envisions the exemption as a check on self-interestedness within marriage, a legal rule that keeps one spouse from unjustifiably betraying the other (or, described more precisely, that keeps wives from betraying their husbands). As one state legislator explains the theory, "since society is already burdened with these kinds of women [vengeful wives], . . the last thing we need is a law making it illegal for a husband to sexually assault his wife." 424

This mode of argument in defense of the marital rape exemption has been very successful. Granted, the law of marital rape has changed more notably in the late twentieth century than in the nineteenth. At the end of a half-century's effort by the first organized woman's rights movement, the only alteration apparent in the legal treatment of marital rape consisted of a marginal liberalization in the divorce law. In contrast, over the past quarter century, a minority of states have eliminated the exemption and many more have modified its reach. Yet the marital rape exemption survives im some substantial form in a majority of states, ${ }^{425}$ in an era in which almost every other aspect of women's legal subordination at common law (including a husband's right to assault his wife nonsexually) has been formally repudiated. ${ }^{426}$ The modern feminist campaign against marital rape, like its nineteenth-century predecessor, has encountered tremendous resistence and had much less of an impact on the law than it aimed for or achieved in other arenas.

of the marital rape cases on its own and then confirm their character with law enforcement officials. See id. at 222-23.

424. Dick Polman, Sexual Assault in the Home: Is Marriage a License to Rape?, HARTFORD ADvoc., Feb. 18, 1981, at 2, 2 (reporting comments of Alfred Onorato of the Connecticut General Assembly).

425. See statutes cited supra notes $1-3,408-409$ and accompanying tcxt.

426. The modern Supreme Court, for instance, has specifically renounced coverture principles on occasion, noting that a married woman is no longer "regarded as chattel or demeaned by denial of a separate legal identity and the dignity associated with recognition as a whole human being." Trammel v. United States, 445 U.S. 40, 52 (1980) (abrogating the common law rule that prevented a wife from voluntarily testifying against her husband); see also Orr v. Orr, 440 U.S. 268, 283 (1979) (striking down gender-based alimony laws); Planned Parenthood v. Danforth, 428 U.S. 52, 67-71 (1976) (striking down spousal consent provisions in abortion statutes); Eisenstadt v. Baird, 405 U.S. 438, 453 (1972) ("[T] he marital couple is not an independent entity with a mind and heart of its own, but an association of two individuals each with a separate intellectual and emotional makeup."). 


\section{B. The Modern Feminist Campaign Against the Marital Rape Exemption}

Although not explicitly phrased this way, the contemporary feminist argument against the marital rape exemption, like that of the mineteenthcentury woman's rights movement, is an effort to establish that marriage is a potentially antagonistic and dangerous relation, in which women need and deserve legal rights to protect themselves from the serious harms caused by unwanted sex in marriage. Modern feminists, for instance, have a radically different understanding of what privacy arguments for the marital rape exemption are safeguarding. In this view, the use of privacy rationales to justify nonintervention in cases of marital rape protects and exacerbates the current distribution of power within a marriage. ${ }^{427}$ Feminists take this distribution to be markedly mibalanced, noting that men are disproportionately richer, stronger, and bigger than their wives. ${ }^{428}$ They contend that privacy arguments for the marital rape exemption keep the state from acting to equalize relations in the wife's interest and add state sanction to the power that husbands exercise. ${ }^{429}$ On this account, the interests of husband and wife are very much unaligned on the question of legal remediation for marital rape, and the overriding function of the privacy defense of the exemption is not to shelter shared intimacy. Instead, the privacy claim gives husbands safety in committing highly injurious conduct that the law would otherwise consider felonious, while simultaneously disabling wives from summoning state resources for their own protection. $^{430}$

427. See MACKINNON, ToWARD, supra note 8, at 193 ("When the law of privacy restricts intrusions into intimacy, it bars changes in control over that intimacy through law. The existing distribution of power and resources within the private sphere are precisely what the law of privacy exists to protect.... [T] he legal concept of privacy can and has shielded the place of ... marital rape ...."); Frances E. Olsen, The Family and the Market: A Study of Ideology and Legal Reform, 96 HARV. L. REV. 1497, 1510 (1983) ("The argument that nonintervention serves to empower husbands to dominate their wives and children has been particularly useful in the attack upon the claimed neutrality of the state with respect to the family."); Katherine M. Schelong, Domestic Violence and the State: Responses to and Rationales for Spousal Battering, Marital Rape \& Stalking, 78 MARQ. L. REv. 79, 113-14 (1994) ("A refusal to intervene in marital relationships that involve assault, battery and/or rape preserves the relationship of domination and subordination. ... [T] he doctrine of family privacy in the face of domestic abuse.... is an effective mechanism by which institutional and individual male power and privilege are maintained and fortified."); West, supra note 9, at 67 ("[T] $]$ he . . reality experienced by the raped wife as a daily ritual of violence, abuse, and horror strikes the feminist as unconscionable state passivity in the face of private subordination ....").

428. See, e.g., West, supra note 9 , at 68 .

429. See sources cited supra note 427.

430. See Thomas K. Clancy, Equal Protection Considerations of the Spousal Sexual Assault Exclusion, 16 New ENG. L. REv. 1, 23 (1980) (arguing that the privacy claim for the marital rape exemption uses privacy "as a shield to allow one marital partner to force the other into nonconsensual acts"); Schelong, supra note 427, at 113-14 ("In applying the right of privacy to cases involving marital rape and domestic violence, tbe right to privacy is claimed by one spouse over the objection of the other. In other words, the abuser's right to privacy is more highly valued than the victim's right to protection, autonomy, and bodily integrity.") (citation and internal quotation marks omitted). 
The feminist response to the marital reconciliation argument similarly stresses the divergent interests of husbands and wives, and the lasting harm that marital rape inflicts on married women. Feminists acknowledge that men who rape their wives will systematically favor a legal regime that permits them to avoid prosecution so that they can attempt to reconcile with their wives on private terms. But they contend that the exemption does not serve women's interests equally well. In this vision, what irreparably destroys marital harmony-from the wife's perspective-is not state prosecution, but the marital rape itself. Even with the exemption from prosecution firmly in place, a wife may have little interest in marital reconciliation after her husband has raped her. ${ }^{431}$ Marital rape causes women severe and abiding injury, femimists explain, and there is good reason for a wife to conclude that she will be better off if she does not reconcile with a husband who has raped her. ${ }^{432}$ Feminists argue that if a wife would be willing to cooperate in her husband's prosecution, the law should not second-guess her assessment of her own interests, even if that assessment diverges from her husband's preferred resolution. ${ }^{433}$

431. See MACKINNON, TowARD, supra note 8, at 177 ("Disallowing charges of rape in marriage may, depending upon one's view of normalcy, 'remove a substantial obstacle to the resumption of normal marital relationships.' Note that the obstacle is not the rape but the law against it." (quoting People v. Brown, 632 P.2d 1025, 1027 (Colo. 1981) (en bane))); Rene I. Augustine, Marriage: The Safe Haven for Rapists, 29 J. FAM. L. 559, 570-71 (1990-91) ("[T]o the extent that a man has forcibly raped his wife, an act of ultimate disrepect and violation, it is unlikely that any marital harmony cxists whicb needs to be preserved."); Clancy, supra note 430, at 23 ("“[R]econciliation hardly seems an expected or likely consequence of a relationship that has deteriorated to the point of forcible sexual advances."' (quoting State v. Smith, 372 A.2d 386, 389 (Essex County Ct. 1977))); Schelong, silpra note 427 , at 114 ("One of the most often cited justifications for the marital rape exemption ... is that the state is fostering marital harmony and intimacy by protecting the privacy of the marital relationship. However, there is no harmonious relationship when the woman is being beaten and raped by her husband."); Note, To Have and to Hold: The Marital Rape Exemption and the Fourteenth Amendment, 99 HARv. L. REv. 1255, 1268 (1986) ("As one court noted, 'it is the violent act of rape and not the subsequent attempt of the wife to seek protection through the criminal justice system which 'disrupts' a marriage."' (quoting People v. Liberta, 474 N.E.2d 567, 574 (N.Y. 1984))).

432. See Augustine, supra note 431, at 571 ("[G]iven that the psychological and physical repercussions of forcible rape are incalculable, the ideal goal should not be toward the reconciliation of the rapist/husband and the victim/wife."); Schelong, supra note 427, at 115 ("[The reconciliation] theory posits that even in the face of rape and assault and battery, state intervention into the marital relationship is inappropriate because it will impede a couple's reconciliation. This necessarily lcads to the conclusion that the family should be kept intact at all costs."); Note, supra note 431, at 1268.69 ("The state has no interest in preserving a deteriorated marriage, and marital rape is one of the strongest signs of such deterioration. Rape itself disintegrates the marriage.... In reality, rcconciliation in the context of marital rape is often a stage in the cycle of psychological dependence upon a violent, abusive husband.").

433. See Note, The Marital Rape Exemption, 52 N.Y.U. L. Rev. 306, 315 (1977) ("IThe reconciliation defense] assumes that in a situation in which a wife is prompted to bring a rape charge against her husband there is a state of marital harmony left to be disturbed. The assumption that the wife will be soothed by denying her the protection of the criminal laws is ludicrous on its face."); Note, supra note 431, at 1268 ("[A] wife's criminal complaint testifies to the absence of marital harmony and intimacy."). 
In these feminist arguments, the injury ignored or denied by the exemption's modern defenders is presented in stark relief. The modern feminist rendering of the wound that narital rape inflicts upon women is somewhat different from the account that the nineteenth-century woman's rights movement provided, reflecting an evolving set of commitments. But contemporary feminists, like their nineteenth-century predecessors, emphasize that marital rape causes women serious harm.

First, modern feminists oppose marital rape on the ground that it deprives women of control over their reproductive capacity. ${ }^{434}$ This argument is the closest present-day equivalent to the nineteenth-century focus on control over the work of motherhood ${ }^{435}$ Reproductive concerns, however, are far less prominent in modern feminist advocacy against marital rape, perhaps because contemporary femimism accepts contraception and abortion as alternate means of limiting fertility. ${ }^{436}$ Modern feminists also concentrate more on the physiological aspects of motherhood (like conception and gestation), ${ }^{437}$ than on the child rearing that occupied the nineteenthcentury movement, a possible manifestation of the contemporary feminist decision to contest women's disproportionate responsibility for raising children.

More frequently, modern feminists argue that marital rape denies women the right to control their sexuality and their chances for sexual pleasure. ${ }^{438}$ This claim from sexual self-sovereignty resembles those articulated by the free lovers in the nineteenth century, ${ }^{439}$ although it would find no equivalent in the organized feminist movement of that period. The first woman's rights movement, operating in an era that understood female sexuality to be weaker than its male counterpart, was more occupied by its effort to limit the downside risks of marital intercourse for women. ${ }^{440}$ Modern feminists, in contrast, tend (like contemporary Americans generally) to be more optimistic about and interested in the possibilities of sexual imtercourse, which has implications for their understanding of the mjury that marital rape inflicts. Their account of harm often notes that a marital rape victim loses the ability to determine her

434. See sources cited infra note 437.

435. See supra Part II.A.

436. For a discussion of the nineteenth-century feminist movement's opposition to contraceptive devices and abortion, see supra text accompanying notes 222-225.

437. See Thomas R. Bearrows, Note, Abolishing the Marital Exemption for Rape: A Statutory Proposal, 1983 U. ILL. L. REv. 201, 218 ("The right to be free from government interference in the decision to use contraceptives inciudes the right to decide which contraceptive to use. . . Rape statutes which include the marital exemption impermissibly burden a woman's decision to use sexual abstinence as a method of contraception."); Note, supra note 431, at 1263 ("[The marital rape exemption] allows him to impregnate her against her will in denial of her reproductive freedom.").

438. See sources cited infra notes 441-442.

439. See supra text accompanying notes 253-260.

440. See supra text accompanying notes 212-221. 
sexual "actions, pleasures, and desires free from external influence." ${ }^{441}$ From this perspective, "[t]he damage occasioned by [marital rape exemptions] is the subordination, and in many cases the annihilation, of the psychic, physical, emotional, and erotic female self." ${ }^{442}$ On a related note, modern feminists also attack marital rape as a violation of wonren's bodily integrity, never a focus of nineteenth-century feminism. The marital rape exemption, in these terms, "manifest[s] disregard for women's bodily integrity and autonomy and, instead, sanction[s] their vulnerability in marriage." 443

The difficulties that the contemporary feminist campaign against marital rape has encountered are particularly remarkable because the modern empirical evidence on marital rape supports the feminists' sexspecific analysis in many ways, delineating how the interests of men and women differ and revealing the traunia that marital rape inflicts upon women. All available evidence, for instance, indicates that marital rape is virtually always committed by husbands on wives. ${ }^{444}$ Indeed, I have been

\section{West, supra note 9, at 69.}

442. Id.; see also Note, supra note 433, at 316 ("[R]ape laws protect a woman's sexual integrity and freedom of choice in an area of utmost intimacy... . The fact that the rape occurs in a marital context does not affect the interests which are violated."); Note, supra note 431, at 1263 ("And perhaps most important, the exemption extinguishes a married woman's autonomy in one of the most personal and intimate of all human interactions.").

443. Linda C. McClain, Inviolability and Privacy: The Castle, the Sanctuary, and the Body, 7 Yale J.L. \& HumaN. 195, 213 (1995); see also Susan Brownmiller, Against OuR Will: Men, WOMEN AND RAPE 381 (1975) ("A sexual assault is an invasion of bodily integrity and a violation of freedom and self-determination wherever it happens to take place, in or out of the marriage bed."); Augustine, supra note 431, at 560 ("A New York court recently explained that " $\mathrm{r}$ ]ape is not simply a sexual act to which one party does not consent. Rather, it is a degrading, violent act which violates the bodily integrity of the victim and frequently causes severe, long-lasting physical and psychological barm." (quoting People v. Liberta, 474 N.E.2d 567, 573 (N.Y. 1984))); Michael D.A. Freeman, "But If You Can't Rape Your Wife, Wholm] Can You Rape?": The Marital Rape Exemption Re-examined, 15 FAM. L.Q. 1, 9 (1981) ("Rape is the denial of self-determination, the rejection of the victim's physical autonomy: it symbolizes ultimate disrespect ... the exercise of the power of consent over another person.") (citation and internal quotation marks omitted); Schelong, supra note 427, at 115 ("The attitude that marital or date rape is a victimless crine, or a lesser crine, is to deny the woman who has been raped bodily integrity, autonomy, and equal protection before the law."); Bearrows, supra note 437, at 219 ("When a husband forces his wife to engage in sexual relations, he invades her physical integrity ...."); Note, supra note 431, at 1263 ("The marital rape exeinption allows a husband to violate his wife's bodily integrity.").

444. Contrary to popular assumption, female-on-inale rape is physiologically possible. See Philip M. Sarrel \& William H. Masters, Sexual Molestation of Men by Women, 11 ARchives SExual BeHav. 117,118 (1982) ("It is evident from this report that men or boys have responded sexually to female assault or abuse even tbough the inales' emotional states during the molestations have been overwhelmingly negative-einbarrassment, humiliation, anxiety, fear, anger, or even terror."); Robert L. Johnson \& Diane Shrier, Past Sexual Victimization by Females of Male Patients in an Adolescent Medicine Clinic Population, 144 AM. J. Psychiatry 650, 651 (1987) ("Thrce-quarters of the female molesters attempted to get their victims to ejaculate, and nearly half succeedcd."); see also A. Nicholas Groth, Men Who Rape: The Psychology of The OfFender 123-24 (1979) (study of male-on-inale rape reporting that "there appeared to be a substantial effort inade by those offenders 
able to locate just a handful of cases in which women may have come to the attention of American law enforcement authorities for raping adult men. ${ }^{445}$ Only a few more examples of female-on-male rape have been reported in the psychiatric literature. ${ }^{446}$ It is possible to predict with almost

who assaulted their victims in the community to get these victims to ejaculate. This occurred in nine (41\%) of the community offenses.").

445. The Justice Department's Bureau of Justice Statistics (BJS) may have uncovered evidence of a very small number of female-on-male rapes. The BJS has begun to implement "a more comprehensive and detailed" methodology for compiling data on crime, known as the National Incident-Based Reporting System (NIBRS). BRIAN A. REAVES, U.S. DEP'T OF JUSTICE, UsING NIBRS Data to Analyze Violent Crime 1 (1993). This system was tested in Alabama, North Dakota, and South Carolina, using their crime data from 1991. These three states reported a total of 3801 incidents of forcible rape or forcible sodomy, which included 3172 incidents in which the sex of both the victim and offender was recorded. Out of these 3172 cases, the states reported that just 6 (or $0.2 \%$ ) involved a male victim and a female offender. See $i d$. at 8 . That is a very low number to begin with, and the NIBRS study employed definitions of forcible rape and forcible sodomy that included acts so classified only because of the youth of the victim. See LAWrence A. Greenfeld, U.S. DeP'T of Justice, SEX OFFENSES AND OFFENDERs 31 (1997) ("Forcible rape is [defined by NIBRS to mean] the carnal knowledge of a person forcibly and/or against that person's will; or not forcibly or against the person's will where the victim is incapable of giving consent because of his/her youth or because of his/her temporary or permanent mental or physical incapacity."); id. ("Forcible sodomy is [defined by NIBRS to mean] oral or anal sexual intercourse with another person, forcibly and/or against that person's will; or not forcibly or against that person's will where the victim is incapable of giving consent because of his/her youth or because of his/her temporary or permanent mental or physical incapacity."). To my knowledge, there is no way to discern from any BJS publications whether the reported rapes involved adult men or male children as victims. The Bureau decided not to analyze the reported female-on-male rapes because of their small number. See REAVES, supra, at 8 ("Because of the relatively small number of rape incidents that did not involve a male offender and a female victim, such cases are excluded from the analyses presented in this report.").

Further evidence of female-on-male rapes coming to the attention of American law enforcement authorities is elusive. I was able to locate a stray announcement in a law enforcement newsletter indicating that Dallas police were looking for two women wanted for raping a man at gunpoint. See Female Rapists Sought in Dallas, Crime ConTrol Dig., Mar. 28, 1977, at 10, 10. But the Federal Bureau of Investigation's Uniform Crime Reports, one of the best sources for statistics on crime, does not even attempt to present data about female-on-male rape. It defines rape as "the carnal hnowledge of a female forcibly and against her will." FEDERAL BUREAU OF INVESTIGATION, U.S. DEP'T OF JUSTICE, CrIME In the UnIted States: 1998 Uniform Crime Reports 23 (1999) (emphasis added).

446. Philip M. Sarrel and William H. Masters have reported the case histories of seven adult men (age 17 or older) who were subjected to forced and unwanted intercourse, or lesser sexual assaults, by adult women. See Sarrel \& Masters, supra note 444, at 120-22, 125-26. One of these cases concerned a husband who had been raped by his wife. See id. at 125; see also William H. Masters, Sexual Dysfunction as an Aftermath of Sexual Assault of Men by Women, 12 J. SEX \& MARITAL ThERAPY 35, 37-39 (1986) (describing three of these same cases in greater detail).

In addition, a team of British psychiatrists recently conducted what appears to be the largest epideiniological study of men's non-consensual sexual experiences to date. The study surveyed 2474 men (age 18 or older) located through 18 general practitioner offices in England. See Adrian Coxell et al., Lifetime Prevalence, Characteristics, and Associated Problems of Non-Consensual Sex in Men: Cross Sectional Survey, 318 BRIT. MED. J. 846, 846 (1999). "Almost 3\% of [the] men reported having non-consensual sex as an adult [age 16 or older]," with non-consensual sex defined broadly to mean sex "where a person(s) uses force or other means so that they can do sexual things to you that you did not want them to do' or 'where a person(s) uses force or other means to make you do sexual things that you did not want to do." Id. at 847 \& tbl.2. Of these men, "32 (46\%)-reported having had non-consensual sex with women (a man and a woman in two cases)." Id. at 847. Out of these 32, 14 
perfect accuracy that marital rape cases will involve the husband as rapist and the wife as victim. The more lopsided the factual circumstances, the easier it is to differentiate the consequences that a marital rape exemption has for men as opposed to women. Within approximately the past twentyfive years, almost all state exemptions have been revised in a genderneutral idiom, so that they now regulate the rape of one "spouse" by the other. $^{447}$ But it is not the case that wives routinely, or even occasionally, benefit from their immunity from prosecution. Just as a factual matter, husbands experience the marital rape exemption by enjoying immunity from prosecution. Wives experience the marital rape exemption as the person who does not receive the protection of the criminal law for acts that would otherwise be considered serious crimes.

Contemporary empirical research also casts valuable light on the extent and nature of the injury that marital rape causes wives, adding support to the ferminist argument that marital rape and the exemption inflict serious harm on women. The best available evidence suggests that approximately one out of every seven or eight married women has been subject to what in the absence of the exemption would be considered to be rape or attempted rape by their husbands. ${ }^{448}$ Sociological studies of marital rape victims have concluded, moreover, that rape can be more traumatic within marriage than outside of it. As one research team explained, these "victims suffer from many of the same traumas as victims of other rapethe humiliation, the physical injuries, the guilt and self-reproach. But they

men reported that they had been made to have intercourse with a female perpetrator. See id. at 848 tbl.3.

The sociological hiterature also estimates that women are responsible for approximately $20 \%$ of the sexual abuse of boys and 5\% of the sexual abuse of girls. See David Finkelhor \& Diana Russell, Women as Perpetrators: Review of the Evidence, in David FInKELHOR, ChILd SEXUAL AbuSE: New THEORY AND RESEARCH 171, 177 (1984) (reviewing studies); see also Johnson \& Shrier, supra note 444 , at 650 ("In an adolescent medicine clinic with more than 1,000 patients during 1982-1984, I I male adolescents reported a history of sexual molestation by females. This molestation had commonly involved acquaintances and was unlikely to have been accompanied by threats of violence or physical coercion.").

447. See infra note 465 and accompanying text.

448. Diana Russell has conducted the largest and most thorough empirical study of marital rape. See RUSSELL, supra note 415, at 1-2. She interviewed a random sample of 930 women and reports that 84 (13\%) of the 644 women who had ever been married revealed that their husbands had raped them or attempted to rape them. See id. at 57 . Russell's definition of rape included "rape by force, rape by threat of force, and rape when the wife is in no position to consent because she is unconscious, drugged, asleep, or in some other way helpless." $I d$. at 43.

David Finkelhor and Kersti Yllo have conducted a smaller and less precise study based on a random sample of 323 women living with a child between the ages of six and fourteen. See FiNKELHOR \& YLLO,supra note 423, at 204. Rather than interview these women about marital rape, Finkelhor and Yllo gave them a written questionnaire asking them: "Has your spouse ever used physical force or threat to try to have sex with you?"' Id. at 203-04. Ten percent of the married or previously married women answered "yes." See id. at 6-7, 205 tbl.A-1. 
suffer some special traumas, too-betrayal, entrapment, and isolation." "The kind of violation they have experienced is much harder to guard against [than rape by a stranger], short of a refusal to trust any man. It touches a woman's basic confidence in forming relationships and trusting intimates."450

There is an even more striking set of materials available that supports the feminist effort to elucidate and condemn the harm of marital rape. Women's contemporary accounts of their own lived experiences of forced sex in marriage render the problem of marital rape vivid in ways that numbers and scholarly findings may not convey. Like perhaps nothing else, the dramatic effect of the anecdotal makes clear the unreality and the ritualistic character of the notion that the marital rape exemption serves a wife's interests as much as her husband's because marital rape causes women no perceptible mjury. The modern defenders of the exemption, for instance, portray a husband's prosecution (rather than the marital rape) as the source of conflict and harm in a marriage. ${ }^{451}$ Women who have been subjected to marital rape tend to understand their situation quite differently. One woman describes her experience of rape in marriage this way:

"It hurt. It wasn't fun at all and I was very mad. . . . I really hated that man-I could have shot him. He didn't care. I've never hated anybody like that. I hope no one else ever has to go through it. It's like a pit inside, it hurts so bad. You don't know how to crawl out of it. You don't know where to turn."

"Sybil," also raped in marriage, would agree. For her as well, the marital rape " "was horrible," leaving her angry, disgusted, and nauseous. Her husband, though, "felt like he'd won something. . . . He feels," " she explains, "like I control when we have sex, and this was showing me that even if I didn't want to, it could happen anyway." "453 "Mrs. James," now divorced, became pregnant with five of her six children through marital rape. ${ }^{454}$ Her assessment of married women's status at the end of the twentieth century echoes Elizabeth Cady Stanton's most radical

449. FINKELHOR \& YLLO, supra note 423, at 137-38. In addition to their written questionnaire, discussed supra note 448, Finkelhor and Yllo also conducted intensive personal interviews with 50 additional marital rape victims, see id. at 9-12. Their conclusions about the trauma that marital rape can inflict are based on those interviews.

450. David Finkelhor \& Kersti Yllo, Rape in Marriage: A Sociological View, in THE DARK SIDE of Families: CuRrent Family Violence Research 119, 126 (David Finkelhor et al. eds., 1983); see also RUSSELL, supra note 415, at 198 ("[W]ife rape is potentially more traumatic than stranger rape, usually perceived as the most dreadful form of rape.... [W]ife rape can be as terrifying and lifethreatening to the victim as stranger rape. In addition, it often evokes a powerful sense of betrayal, deep disillusionment, and total isolation.").

451. See supra text accompanying notes 415-424.

452. FinKelHOR \& YLLo, supra note 423, at 117.

453. Id. at 49.

454. See RUSSELL, supra note 415, at 196. 
declarations. "'I vowed I'd never ever marry again," she observes. "'I'd never be in a position where men have authority over me. Marriage is license to do anything you want. You're not a whole person because no one respects your rights as a human being." 455

Many women's experiences combine marital rape and wife beating, doubly undercutting the proposition that the exemption is protecting marriages that are otherwise peaceful, harmonious, and mutually supportive. "Sophia's" husband, for example, beat her while he raped her. In her words, her "'whole body was being abused." ${ }^{456}$ She found the rapes even more traumatic than the beatings. "'I feel if I'd been raped by a stranger, I could have dealt with it a whole lot better,", she says.

"When a stranger does it, he doesn't know me, I don't know him. He's not doing it to me as a person, personally. With your husband, it becomes personal. You say, This man knows me. He knows my feelings. He knows me intimately, and then to do this to me-it's such a personal abuse." $" 57$

"Jean Michel," just twenty-four-years-old when interviewed, would second that conclusion." 458 " "There's soinething worse about being raped than just being beaten," she explains. "'It's the final humiliation, the final showing you that you're worthless." "459 After her husband raped her, she "“felt very dirty,", "“humiliat[ed]," "“filthy, used." "460 As she reports: "'I haven't begun to deal with it, and I'm not sure that I ever will be able to. I keep wishing there was some way I could work through this rage that I have about it, but I don't see any way to do it." ${ }^{\text {" } 461}$

\section{The Lessons, and the Promise, of History}

Despite the availability of this dramatic record of injury, the modern feminist attempt to explain the marital rape exemption in terms of the divergent, even antagonistic, interests of husbands and wives has not been particularly effective. In part, the consensual account of the history of marital rape, now accepted by supporters and opponents of the exemption alike, helps explain the success of the exemption's modern defenders. The proposition that the marital rape exemption serves the shared interests of husbands and wives is likely to appear more reasonable, even commonsensical, if one approaches the exeinption with the assumption that it has long been the subject of consensual agreement between men and women. That proposition would be more difficult to maintain if the historical

455. Id.

456. FINKELHOR \& YLLO, supra note 423, at 118.

457. Id.

458. See Diana E.H. Russell, The Polmics of Rape: The Victim's Perspective 71 (1975).

459. Id. at 77 .

460. Id. at 79 .

461. Id. at 79-80. 
contest over marital rape, in which feminists vociferousiy opposed a husband's conjugal prerogatives as the ultimate foundation of women's subordination in marriage, were widely known. As this Article has revealed, the marital rape exemption did not survive into the twentieth century because it lacked opposition or because no organized cohort of women thought that the exemption operated to the benefit of husbands but the great detriment of their wives.

Still, it would be implausible to suggest that the present legislative commitment to preserving some substantial form of the marital rape exemption, and the judicial decision to not intercede under the Equal Protection Clause, would instantly collapse, if the historical struggle over marital rape became common knowledge. If the fate of the nineteenthcentury campaign against a husband's conjugal prerogatives illuminates anything, it is that society's reluctance to acknowledge that marriage is a potentially antagonistic and dangerous relation by giving women legal rights against their husbands is long-standing, well-entrenched, and extremely resistant to feminist opposition, especially where marital sex and reproduction are directly implicated. Even the nineteenth-century prescriptive authors who expounded at length on the harm that marital rape was inflicting on wives were unwilling to translate that social recognition into support for granting women legal entitlements. Where feminists made a rights claim advancing women's interests as they were distinct from and defined in opposition to those of men, the prescriptive literature put forth a series of suggested strategies for marital harmony and happiness. Authoritative legal sources, in turn, absolutely refused to alter a husband's exemption from prosecution for raping his wife. After a half-century of writing and advocacy (feminist and otherwise) exploring sexual abuse in marriage, the only change in the legal status of marital rape consisted of a marginal amelioration in the terms on which divorce was available to (privileged) women.

Phrased another way, then, one reason that people are so attracted to the consensual account of the history of marital rape in the first place is that we greatly prefer to envision marital relations as loving, mutually supportive, and harmonious, rather than loathsome, abusive, and conflictridden-even though, as a practical matter, we encounter evidence all the time that the latter state of affairs characterizes some relationships. That cultural denial helps explain, for instance, the studies finding that even people who know current divorce rates believe that the possibility that they will divorce is negligible and fail to plan rationally for the contingency. ${ }^{462}$ The contemporary defense of the marital rape exemption is one

462. In one study, Lynn Baker and Robert Emery surveyed people "who had recently applied for a marriage license ... and who had not previously been married." Lynn A. Baker \& Robert E. Emery, When Every Relationship Is Above Average: Perceptions and Expectations of Divorce at the Time of 
of the most conspicuous, if bizarre, expressions of this phenomenon. Modern courts, lawmakers, and commentators are never more anxious to expound upon the wonders of marital love, trust, intimacy, and respect than when a husband's freedom from prosecution for raping his wife is at stake.

The cultural need to understand marital relations as consensual and harmonious also helps explain another phenomenon of approximately the last quarter-century. ${ }^{463}$ During this period, dozens of states revisited their marital rape exemptions, but decided to retain them in substantial form nonetheless. One result of this review was that states modified the scope of their exemptions. ${ }^{464}$ Another result was that virtually every one of these states rewrote its marital rape exemption in gender-neutral terms, ${ }^{465}$ in contrast to the explicit and enthusiastic gender-specificity of the common

Marriage, 17 LAW \& HUM. BEHAV. 439, 440 (1993). "[W]hen asked to estimate the percent of couples in the U.S. who mary today who will get divorced at some time in their lives, the median response given by the license applicants was $50 \%$, the closest correct approximation." Id. at 442 (citation omitted). But "the median response of the marriage license applicants was $0 \%$ when assessing the likelihood that they personally would divorce." $I d$. at 443 . The respondents also expressed unrealistic optimism about the likely consequences if their marriages did end. For instance, "[a]lthough the median female respondent estimated (very optimistically) that $40 \%$ of divorcing women are awarded alimony, $81 \%$ of the female respondents expected that the court would award alimony to them if they requested it at divorce." Id. "Fully $100 \%$ of the respondents who expected to be awarded alimony upon divorce," moreover, "predicted that their spouse would completely comply with the court's award." Id.; see also Neil D. Weinstein, Unrealistic Optimism About Future Life Events, 39 J. PERSONALITY \& SOC. PsYchol. 806, 809, 810 tbl.1 (1980) (reporting that college students were nine and one-half times more likely to estimate their chances of divorcing a few years after marriage as lower than average).

463. See Wallace D. Loh, $Q$ : What Has Reform of Rape Legislation Wrought? A: Truth in Criminal Labelling, 37 J. Soc. Issues 28, $28-29$ (1981) ("Since the enactment in 1974 by Michigan of the first comprehensive reform rape legislation in the nation, some forty states have modified existing or passed new statutes on rape.") (citations omitted); Cassia C. Spohn, The Rape Reform Movement: The Traditional Common Law and Rape Law Reforms, 39 JuRIMETRICs J. 119, 120-21 (1999) ("Rape law reform quickly became a key item on the feminist agenda ["in the early 1970s']. . . . [Feminists] were joined in their efforts by crime control advocates ... . These groups formed a powerful, although perhaps ill-matched, coalition. By the mid-1980s, nearly all states had enacted some type of rape reform legislation.").

464. See statutes cited supra notes $1-3,408-409$ and accompanying text.

465. For instance, all of the statutes cited supra notes 1-3, 408-409 are written in gender-neutral terms. As recently as 1980 , in contrast, 18 states and the District of Columbia still had gender-specific rape statutes, and 3 additional states had switched to gender-neutrality in just the 3 prior years. See Hubert S. Feild \& Leigh B. Bienen, Jurors and Rape: A Study in Psychology and Law 207. 458 (1980); see also Panel on Research on Violence Against Women, National Research Council, Understanding Violence Against Women 125 (Nancy A. Crowell \& Ann W. Burgess eds., 1996) ("Beginning in the mid-1970s and continuing throughout the $1980 \mathrm{~s}$.... [m]ost states moved to a gender-neutral definition of rape that includes vaginal, anal, and oral penetration by body parts or other objects."); Ronald J. Berger et al., The Dimensions of Rape Reform Legislation, 22 L. \& Soc'y REv. 329, 332 (1988); Leigh Bienen, Rape Reform Legislation in the United States: A Look at Some Practical Effects, 8 Victimology 139, 141 (1983); Anne L. Buckborough, Family Law: Recent Developments in the Law of Marital Rape, 1989 ANN. Surv. AM. L. 343, 349; Julie Horney \& Cassia Spohn, Rape Law Reform and Instrumental Change in Six Urban Jurisdictions, 25 L. \& Soc'Y Rev. 117, 118 (1991); Patricia Searles \& Ronald J. Berger, The Current Status of Rape Reform Legislation: An Examination of State Statutes, 10 WoMEN's RTs. L. REP. 25, 26 (1987). 
law formulation. ${ }^{466}$ This latter, linguistic change has almost no practical consequences, given the accuracy with which one can predict that marital rapes will be committed by husbands on wives. ${ }^{467}$ But as a matter of modern equal protection doctrine, it is very important. Statutes that explicitly classify by sex are automatically subject to heightened scrutiny under the Equal Protection Clause, which relatively few statutes have managed to survive. ${ }^{468}$ Once a statute has been made formally gender-neutral, however, it is subject to heightened scrutiny only if a plaintiff can establish the equivalent of legislative malice: that the gender-neutral statute was enacted 'at least in part 'because of,' not merely 'in spite of,' its adverse effects upon" women. ${ }^{469}$ This is precisely the sort of malignant motivation that is least likely to be uttered in the constitutionally conscious age in which we live. So, as a practical matter, modern marital rape exemptions are subject to rational basis review. Although a small number of state courts have found exemptions unconstitutional on a rational basis analysis, ${ }^{470}$ a marital rape exemption is likely to survive this relatively

466. See supra Part I.B.

467. See supra text accompanying notes $444-447$.

468. The explicit sex-based classifications that have survived heightened scrutiny in the Supreme Court tend to fall imto a small set of regulatory categories. A number of decisions turned on women's gestational capacity. In Michael M. v. Superior Court, 450 U.S. 464 (1981) (plurality opinion), a plurality of the Supreme Court upheld a statutory rape law that punished only male perpetrators, on the ground that "the risk of pregnancy itself constitute[d] a substantial deterrence to young females. ... A criminal sanction imposed solely on males thus serve[d] to roughly 'equalize' the deterrents on the sexes." Id. at 473. Lehr v. Robertson, 463 U.S. 248 (1983), involved a New York law that granted all biological mothers, but only some biological fathers, the right to veto the adoption of an illegitimate child and the right to prior notice of any adoption proceeding, see id. at 266 . The statute conditioned fathers' rights on requirements designed to indicate that they had established a relationship with their child. See id. at 250-51. The Court permitted the distinction. See id. at 265-68.

Two other cases upholding explicit sex-based classifications under heightened scrutiny concern military policy. See Rostker v. Goldberg, 453 U.S. 57, 78-79 (1981) (upholding male-only military registration on ground that " $[\mathrm{m}] \mathrm{en}$ and women, because of the combat restrictions on women, are simply not similarly situated for purposes of a draft or registration for a draft"); Schlesinger v. Ballard, 419 U.S. 498, 499-500, 508, 510 (1975) (upholding statutes that granted women more time to secure promotions in the navy before they were subject to mandatory discharge, on ground that combat restrictions on women made their advancement more difficult).

Additional cases concern federal benefits. See Heckler v. Mathews, 465 U.S. 728, 730-31, 745-51 (1984) (permitting temporary sex-based classification in spousal benefit provisions of Social Security Act in order to ease transition to judicially mandated gender-neutral regime); Califano v. Webster, 430 U.S. 313, 314-16, 318 (1977) (per curiam) (permitting a more favorable rnbric for calculating women's earnings for purposes of social security benefits, on ground that distinction "operated directly to compensate women for past economic discrimination").

469. Personnel Administrator v. Feeney, 442 U.S. 256, 279 (1979) (rejecting equal protection challenge to the Massachusetts veterans' preference statute because "nothing in the record demonstrates that this preference for veterans was originally devised or subsequently re-enacted because it would accomplish the collateral goal of keeping women in a stereotypic and predefined place in the Massachusetts Civil Service").

470. See Merton v. State, 500 So. 2d 1301, 1303, 1305 (Ala. Crim. App. 1986); Williams v. State, 494 So. 2d 819, 826, 830 (Ala. Crim. App. 1986); People v. M.D., 595 N.E.2d 702, 708, 712-13 (Ill. App. Ct. 1992); People v. Liberta, 474 N.E.2d 567, 573, 575 (N.Y. 1984); People v. Naylor, 609 
unrigorous level of constitutional scrutiny, which asks only whether the legislature has articulated one reason for the exemption that the court is willing to accept as rational. ${ }^{471}$

Modern feminist critics, including most prominently Robin West, have provided an excellent doctrinal analysis of the status of genderneutral laws under contemporary equal protection doctrine, and explained the difficulties that the modern feminist campaign against the marital rape exemption has encountered as rooted in the inadequacy of that doctrine. ${ }^{472}$ But feminists have not devoted nearly as much attention to the question of why the Supreme Court might have chosen to privilege gender-neutral laws in the first place, and whether there is something more behind the states' move to gender-neutral marital rape exemptions than a desire to survive constitutional scrutiny. The fate of the historical struggle over marital rape, and the nature of the modern arguments put forth in the exemption's defense, suggest that the focus on gender-neutralization is tapping into a larger cultural story about mutuality in relations between the sexes, particularly in marriage.

The effect of the current equal protection doctrine on genderneutrality is to treat men and women as occupying interchangeable roles, in all cases except where the text of the statute or explicit legislative statements of malicious imtent force the court to do otherwise. It is a doctrinal methodology for disregarding evidence about gender-specific consequences that suggests the possibility that the interests of men and women may be unaligned, differentially affected, even antagonistically opposed to one another, and not interchangeable at all. Marital rape

N.Y.S.2d 954, 956 (App. Div. 1994); People v. De Stefano, 467 N.Y.S.2d 506, 516 (Suffolk County Ct. 1983); Shunn v. State, 742 P.2d 775, 778 (Wyo. 1987).

471. See, e.g., People v. Brown, 632 P.2d 1025, 1027 (Colo. 1981) (en banc) (upholding marital rape exemption under rational basis review); People v. Flowers, 644 P.2d 916, 917-18 (Colo. 1982) (en banc) (adhering to earlier decision in Brown); West, supra note 9, at 67-68.

472. See West, supra note 9, at 45-51, 63-71 (describing why it is so difficult to establish the unconstitutionality of marital rape exemptions under current equal protection doctrine, especially when those exemptions are linguistically gender-neutral). West explains her argument this way:

My argument will be that the endurance of marital rape exemptions, despite their apparent unconstitutionality, partly results from the dominant understanding of the meaning of equality and constitutionally guaranteed equal protection. This understanding, particularly as elaborated by the present Supreme Court, obfuscates the unconstitutionality of marital rape exemptions. ... . In other words, the endurance of marital rape exemptions partly is a function of the inadequacy of the dominant or mainstream political theory of cquality, which informs dominant legal understandings of the constitutional mandate of equal protection.

... [T]he inadequate theories of equality and equal protection that we have inherited.... also are a product of the adjudicative institutional context in which those theories have evolved.... This adjudicative context, I believe, has skewed and limited our understanding of equal protection and our understanding of how we should make the promise of equal protection a reality.

Id. at 49-50; see also Note, supra note 431, at 1267-72 (arguing that marital rape exemptions, whether gender-specific or gender-neutral, violate the Equal Protection Clause's prohibition on sex discrimination). 
exemptions are not the only statutes with disproportionate consequences for women to have undergone recent revision into a gender-neutral idiom. Child custody ${ }^{473}$ and alimony laws ${ }^{474}$ are now almost uniformly genderneutral, and wife beating statutes now regulate "spousal abuse." I775 Indeed, this impulse substantially predates modern equal protection law: State interspousal tort immunity doctrines, first developed when married women gained the right to sue in their own names in the middle of the nineteenth century, were phrased in gender-neutral terms from the outset. ${ }^{476}$ Yet the strength of the yearning to insist within the law that the interests of men and women always harmoniously comcide is nowhere more apparent than with the marital rape exemption, where the sex-specificity of the underlying conduct and injury is extraordinarily pronounced, but equal protection doctrine nonetheless treats husbands and wives as though they occupy unassigned positions.

473. See Mary Ann Mason, Motherhood v. Equal Treatment, 29 J. FAM. L. 1, 20-21 (1990-1991) ("In the 1970's and 1980's, on the heels of no-fault divorce legislation, most states rushed to eliminate the maternal preference presumption. Currently only seven states give mothers an automatic preference through case law. Many states rewrote their statutes regarding custody to present a gender neutral standard."); Henry H. Foster \& Doris Jonas Freed, Life with Father: 1978, 11 FAM. L.Q. 321, 332 (1978) ("[T]he tender years doctrine [preferring maternal custody] has lost ground so that in 1978 it is either rejected or relegated to the role of 'tie breaker' in most states. ... [I]n twenty-two states the tender years doctrine is rejected by statute or court decision. It has a doubtful status in three states."); Elizabeth S. Scott, Pluralism, Parental Preference, and Child Custody, 80 CALIF. L. REv, 615, 620 n.10 (1992) ("California led the way in abandoning a maternal preference, moving in 1972 to a gender-neutral standard.").

474. As late as 1969 , twenty-six states and the District of Columbia defined alimony as an award that could only pass from a man to a woman. See Kay, Equality and Difference, supra note 399, at 12 n.33. The balance soon shifted, however. By 1979, "about forty states had already 'desexed' alimony and had authorized its award, under appropriate circumstances, to either spouse." Doris Jonas Freed \& Timothy B. Walker, Family Law in the Fifty States: An Overview, 21 FAM. L.Q. 417, 474 (1988). That year, the Supreme Court found gender-specific alimony laws unconstitutional under the Equal Protection Clause. See Orr v. Orr, 440 U.S. 268, 283 (1979). The decision forced the remaining states to adopt gender-neutral formulations of their alimony statutes. See, e.g., Lee Hargrave, Louisiana Constitutional Law, 46 LA. L. REv. 535, 542-43 (1986) (on Louisiana); Isabel Marcus, Reflections on the Significance of the Sex/Gender System: Divorce Law Reform in New York, 42 U. MIAMI L. REv. 55, 71 (1987) (on New York); Ronald J. Resmini, The Law of Domestic Relations in Rhode Island, 29 SuFFolk U. L. REv. 379, 411 (1995) (on Rhode Island); Note, The Signiflcance of Stokes v. Stokes: An Examination of Property Rights Upon Divorce in Georgia, 16 GA. L. REv. 695, 705 (1982) (on Georgia).

475. As Reva Siegel has observed:

While general criminal assault statutes were often used to regulate "domestic disturbances,"

it was also cominonplace for judicial opinions, statutes, and law enforcement policies to refer to the conduct as "wife beating" or otherwise to discuss the parties involved in gender-specific terms. After 1976, when the Court decided in Craig v. Boren that sex-based state action would be subject to a heightened or intermediate standard of review under the Equal Protection Clause of the Fourteenth Amendment, all this began to change. Residual gender-specific references were deleted from the law and replaced with gender-neutral language, with the result that the conduct is now generally referred to as "spousal assault" or "domestic violence."

Siegel, "The Rule of Love," supra note 11, at 2189-90.

476. See id. at 2161-70, 2192. 
All this indicates that there are deep-seated reasons why the course of the modern effort against marital rape importantly resembles that of its nineteenth-century predecessor, where feminists campaigning to unseat a husband's conjugal prerogatives had much less of an impact on the law than they sought, or won elsewhere. There is no easy path upon which contenuporary feminists might proceed, given the profound and long-lived societal reluctance-particularly where marital intercourse and reproduction are at issue - to formulate women's legal rights around the understanding that marital relations are potentially antagonistic and dangerous. There is, however, a very pertinent difference between the arena in which the first organized wonian's rights movement operated and the contemporary environment, which suggests that the future fate of the modern feminist campaign agamst marital rape need not track the historical record.

In the latter half of the nineteenth century, the proposition that niarital rape inflicted severe harm upon nuarried women was widely acknowledged. The prescriptive literature described this harm in great detail. Authoritative legal sources, moreover, never denied the proposition, and courts occasionally remarked upon it themselves while deciding divorce cases later in the century. Recall, for instance, that when a New Jersey court wanted to underscore the weakness of Abby English's divorce petition for sexual cruelty, it cited medical testiniony that, "although there would be pain" whenever English was forced to have intercourse, "a large proportion of married women assent under exactly those circumstances. ${ }^{247}$ In an age that still accepted and endorsed a vast range of legal structures explicitly subordinating women to men, this recognition of injury was not enough to persuade either popular experts on marriage or lawmakers to repudiate a husband's legal right to rape his wife.

The nuodern defenders of the marital rape exemption, in contrast, submerge and deny the harm that the rule causes wonien. This has been good strategy for a reason. It is much more difficult to justify the harm that marital rape inflicts upon wives, and explain the absence of legal reniediation, in a nation now formally committed to women's legal equality and the undomg of women's subjection at common law. ${ }^{478}$ The historical record helps make this harm concrete, revealing the ways in which it is buried by the contemporary defense of the marital rape exemption. If the injury that marital rape inflicts were n1ore systematically put at issue, and argunients presuming that marital relations never cause women harnı were more systematically resisted, it might be harder for the legal system to continue to shelter a husband's conjugal prerogatives. Certainly, building on this

477. English v. English, 27 N.J. Eq. 579, 582 (1876).

478. See supra note 426 and accompanying text. 
excavation of injury would be a useful place for the modern feminist opposition to marital rape to begin its work anew. 
